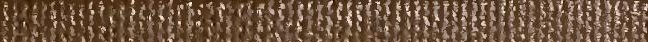

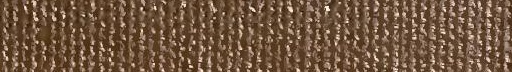

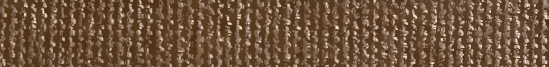

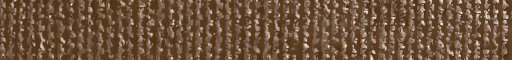

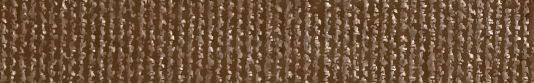

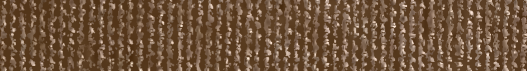
Howhowhom

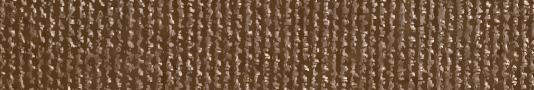

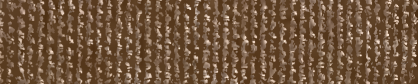

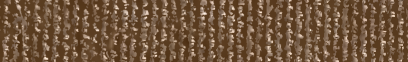
H.

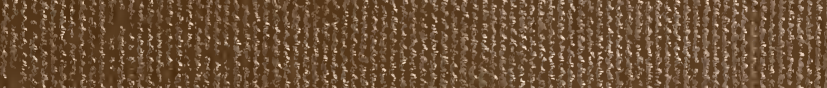

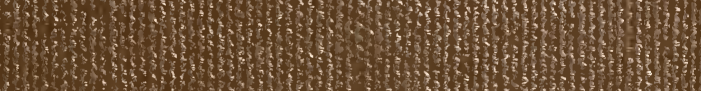

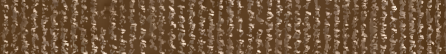

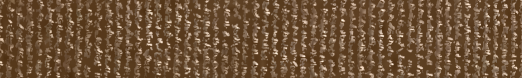
(1.)

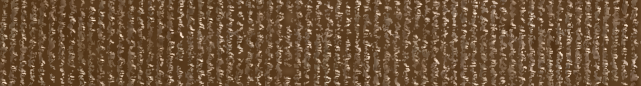

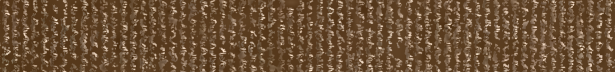

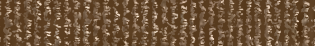

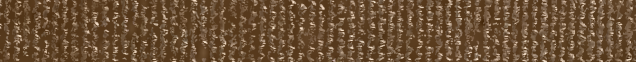

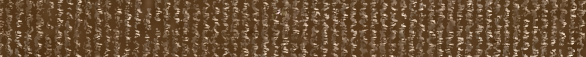

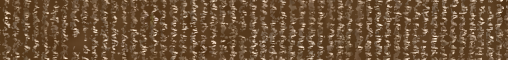

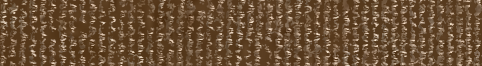

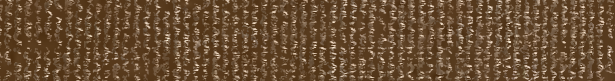

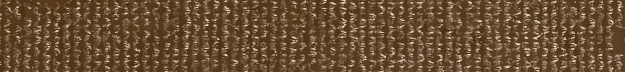

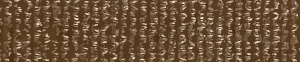
W) 19.7f 8.

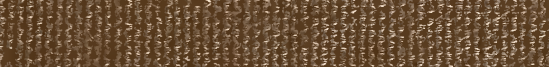
(3) 195)

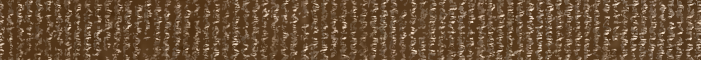

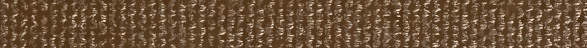

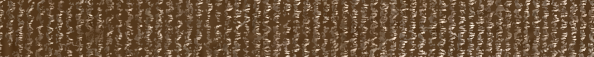

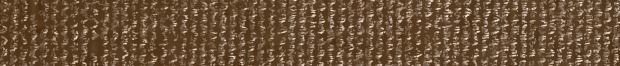

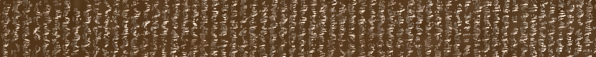

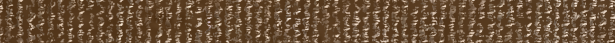

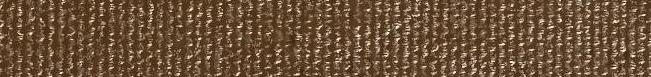

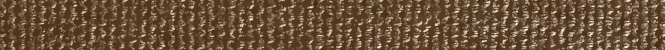

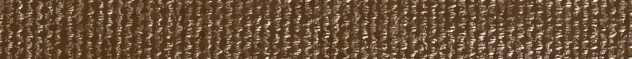

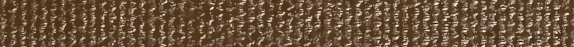

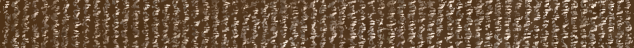

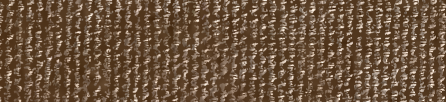

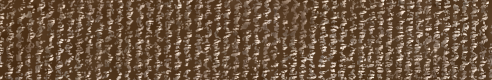

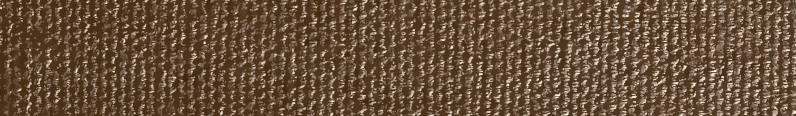

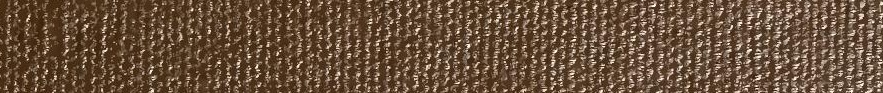
(x) 



3 


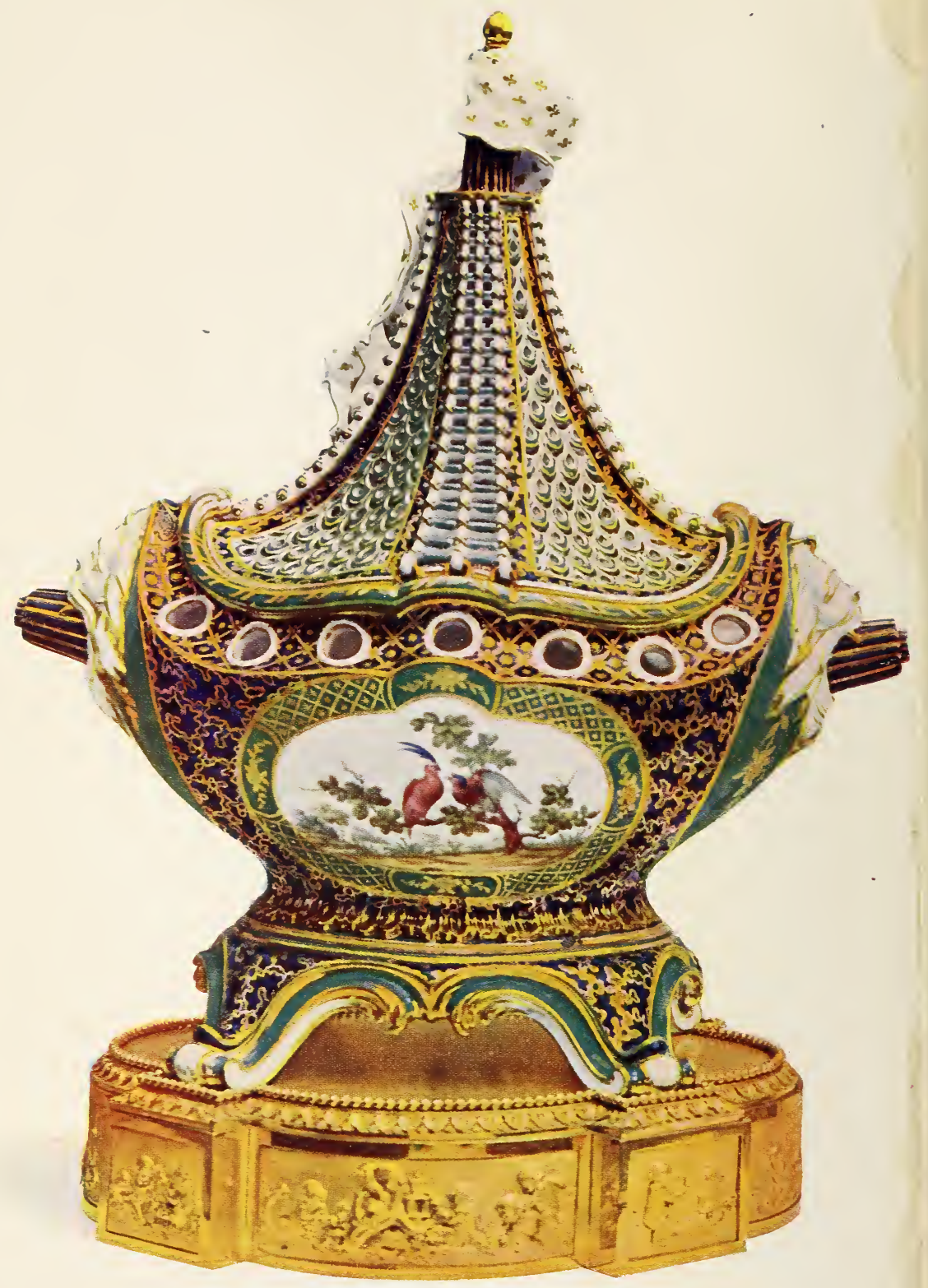



PLATE I.

\section{VINCENNES Or SHVRES}

(PÂTE TENDLE, 1755 OR 1756).

$$
\text { Vase, Vaisseau à mât. }
$$

Grounds of Bleu-de-roi (Vermicule) and Apple-green; Panel decorated with Paistings of Exotic Birds. The Top of the Mast bears a White Flak powdered with Gold Fleurs-de-lys. Pedestal of Bronze, Gilded.

Tallace Collection, No. 156, Gallery XTIII. 


\title{
HISTORY AND DESCRIPTION
}

OF

\section{FRENCH}

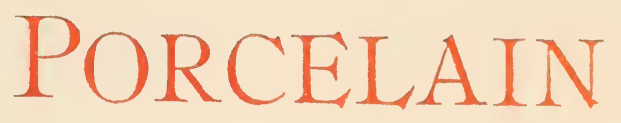

BY

\author{
E. S. AUSCHER
}

INGÉNIEUR DES ARTS ET MANUFACTURES, INGÉNIEUR ET CHEF DE FABRICATION A LA MANUFACTURE NATIONALE DES PORCELAINES DE SÈVRES (1879-1889)

TRANSLATED AND EDITED BY

WILLIAM BURTON, F.C.S. AUTHOR OF "HISTORY OF ENGLISH PORCELAIN," ETC.

CONTAINING TIVENTY-FOUR PLATES IN COLOURS, TOGETHER WITH REPRODUCTIONS OF MARKS AND NUMEROUS ILLUSTRATIONS

CASSELL AND COMPANY, LIMITED LONDON, PARIS, NEW YORK \& MELBOURNE. MCMV 


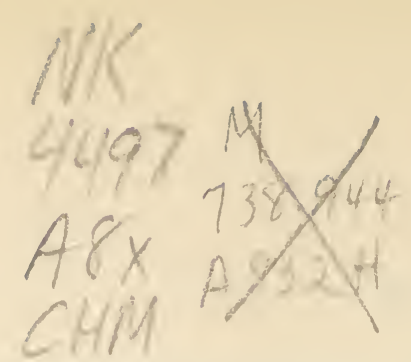

The three-colour and half-tone blocks for this work were made and printed by Messrs. André \& Sleigh, Ltd., of Bushey, Herts. 


\section{P REF A CE.}

The history of French porcelain must always be full of interest to the English reader because, beyond the intrinsic merits of the material and the marvellous technical skill displayed in the finest examples of French porcelain, we can never forget that the earliest English porcelains, particularly those of Bow and Chelsea, owed so much, both directly and indirectly, to our neighbours across the Channel.

We need offer no excuse, therefore, for this new work on the history of French porcelain, written by a hand so competent as that of Mr. E. S. Auscher, who, besides having been "Chef de Fabrication" at the Sèvres manufactory from 1879 to 1889, has a European reputation for his knowledge of all matters connected with the manufacture of porcelain. Mr. Auscher has been collecting materials for this history of French porcelain for many years, and it seems to me a fortunate circumstance that the results of his labours should make their appearance in England, where to-day so many magnificent collections of the old soft-paste porcelains exist.

The artificial soft-paste porcelain, composed of a large proportion of glass or frit, with a small proportion of marl and chalk, and glazed with a luscious glaze rich in lead, is often distinctively spoken of on the Continent as "French porcelain," just as true felspathic porcelain is spoken of as "German 
porcelain," because these two entirely dissimilar products were first perfected, in Europe, in those countries.

The artificial French porcelain was extremely difficult, and therefore costly, to manufacture, for reasons which are most clearly explained in this volume. In no other country but France was its manufacture continued for any considerable length of time; for while the earliest English porcelains were undoubtedly very similar in composition to those of Chantilly, Mennecy, Vincennes, and Sèvres, the ingredients were soon modified, and the manufacture rendered more certain, by the addition of bone-ash to the materials of the paste; an innovation which finally became common at all the English factories and led to our characteristic English bone-porcelain.

Long after this change had commenced in England the French factories continued to manufacture their costly artificial porcelain, and it was not until the latter part of the eighteenth century that this distinctively French product was abandoned for a simpler, and cheaper, hard-paste porcelain analogous to that of Germany and of the Far East.

It was only by the patronage of great nobles like the Prince de Condé at Chantilly, the Duc de Villeroy at Mennecy, and the King of France and his favourites at Vincennes and Sèvres, that the manufacture was able to persist so long, and no one can read Mr. Auscher's account of the enormous sums of money lavished on these undertakings without realising the precarious nature of the early French porcelain industry.

From the modest commencements of the French porcelains produced at Rouen and St. Cloud at the end of the seventeenth century, with their simple decorative patterns in under-glaze blue, to the triumphant productions of Sèvres between 1756 and 
1770, when all that unlimited expenditure and the highest technical skill could accomplish was lavished on the pieces produced for the Royal palaces of France, we have practically an unbroken record of French taste and French craftsmanship for three-quarters of a century.

The most fastidious artist cannot but feel the charm of the material and colour of the rare pieces of Rouen, the early examples of St. Cloud, made in imitation of the white porcelains of Fuchien, and the Chantilly wares decorated with "Kakiyemon" designs on an opaque and milk-white glaze.

But the later and more elaborate productions of Vincennes and Sèvres are on a different plane. Where we are able to see the white material it charms us by its tender, translucent quality, recalling Hellot's description of " a porcelain with a fine, solid white grain like squeezed snow"; the freshness and beauty of the coloured grounds whether of turquoise, apple-green or rosePompadour, are quite unrivalled among colours applied over the glaze; the pieces are enriched with the most skilful painting, relieved by the richest gilding: they are, in a word, marvels of technical skill. Perfectly embodying the taste of their period, the most skilful works of their kind that have ever been produced, they set the fashion so completely in France, as well as in England and other European countries, that the Sèvres styles, Sèvres patterns, and Sèvres ideals were accepted and followed, almost as an article of faith, for more than a century. To-day, however, probably no one would deny that artistically these wonderful pieces of old Sèvres cannot be compared to Chinese single-coloured or Flambé porcelains, to the painted faïences of Persia or Asia Minor, or to Italian majolica of the best period.

Collectors and connoisseurs in every country have owned the 
charm of French porcelain in unstinted measure, and they cannot but appreciate an account of the rise and progress of all the noted French porcelain factories so clear and logical, yet so full and precise, as that given by Mr. Auscher. It may seem invidious to single out any portions of the work for special mention, but Chapter IX. "The Attempts to produce Hard-paste Porcelain in France"; Chapter XIII., on "The Sèvres Biscuits"; and Chapter XVII., on "Modern Derelopments," contain much that will be new to the majority of English readers; while the final chapter on "Forgeries" should prove invaluable to every collector.

The publishers have spared no pains or expense in the illustration of the work, and many of the coloured illustrations are the most faithful renderings of perfect examples that have been made hitherto.

I have to thank in Mr. Auscher's name, as well as my own, the keepers of the various English and French museums for their kindness in according facilities for obtaining the necessary photographs; and our fullest acknowledgments are due to M. Georges Papillon for his permission to reproduce the marks of the Sèvres painters and decorators, which will be found at the end of the Section on "Marks." Lastly, I must thank Mlle. Wolters for invaluable assistance in the work of translation, and Mr. E. G. Hawke for his kindness in reading the proof-sheets.

William BuRtor.

Clifton Junction,

Near. Manchester.

February, 1905. 


\section{CONTENTS.}

CHAPTER PAGE

I. The Invention of Porcelain in France . . . 1

II. First Essays in Paris, and First Successes in Rounn 13

III. Development of the Manufacture of Soft Porcelain at St. Cloud. Its Manufacture at Lille 19

IV. The Soft Porcelain of Chantilly . • . . 30

V. The Soft Porcelaix of Mennecy-Villerov . . 34

VI. The Establishment of a Manufactory at VinCENNES. • . . . . . . . 39

VII. Vincennes: a Roval Manufactory . . . . 51

VIII. The Royal Manufactory of Soft Porcelain at SÈVRES, 1756-1769 .

IX. The Attempts to Produce Hard-Paste Porcelaix IN Frayce. . . . . . . . 70

X. The Last Manufactories of Soft-Paste Porcelain: Sceaux, Bourg-la-Reine, Orléans, Tournat, Arras, St. Amaxd . . . . . . 82

XI. SÈVRES From 1769 to 1774 . . . . . . 88

XII. SÈvres Under LouIS XVI., 1774-1789 . . . . 93 
XIII. Sèvres "Biscuits" under Louis XV. ANd Louis XVI. . . . . . . . . . 108

XIV. The Hard-Paste Porcelain Factories of France, Froy the Discovery OF KAOLIN to THE Revolution $\quad . \quad . \quad . \quad . \quad . \quad . \quad .116$

XV. Sèvres During the Revolution . . . . . 141

XVI. Sèvres under the Direction of Alexandre BrongMiart. . . . . . . . 149

XVII. A Sketch of the Modern Developnents of French Porcelain . . . . . . . . 160 XVIII. French Porcelain Forgeries . . . . . 169 


\section{LIST OF COLOURED PLATES.}

PLATE

I.-Vincennes or Sèvres.-Vase : vaisseau à mât . . Frontispiece

II.-Chantilly.-Flower-holders in the form of Statuettes . . . . . . . To face page 8

III.-Chantilly.-Lobate Sugar-box and Stand . . " " 30

IV.-Vincennes or Sèvres.-Oval Pot-pourri Vase . $\quad$ „ 50

V.-Sèvres.-Pierced Vase Jardinière with Dolphins " " 52

VI.-Sèvres.-Vase Jardinière on a Pedestal . . " " 58

VII.-Sèvres.-Jardinière with rose-Pompadour ground $\quad$ " $\quad 60$

VIII.-Sèvres.-Inkstand presented to Marie Antoinette by Louis XV. . . . . . . $\quad$. 62

IX.-Sèvres.-Candlestick-vase with Elephants' Heads $\quad$ " 64

X.-Sèvres.-Rose-water Ewer and Dish . . . " " 68

XI.-Sèvres.-Jardinière with rose-Pompadour ground " $\quad 72$

XII.-Sèvres.-Covered Basin and Stand . . . " " 74

XIII.-Sèvres.-Covered Vase (vase calice) . . . . " , 78

XIV.-Sceaux.-Flower-pot decorated with Flowers . " " 82

XV.-Bourg-la-Reine.-Sugar-box and Stand . . " " 84

XVI.-Sèvres.-Vase with vert foncé ground . . " ” 88

XVII.-Sèvres.-Vase with bleu-de-roi and oil-de-perdrix ground . . . . . . . . . $\quad \cdots \quad 90$

XVIII.-Sèvres._-"Jewelled Sèvres" Vase . . . " " 102

XIX.-Sèvres.-Plate of the Service executed for Catherine II. of Russia . . . . " " 104

XX.-Sèvres.-Sugar-box and Cream Jug . . . " " 140

XXI.-Sèvres.-Egg Boiler (Coquelle) . . . . . " 142

XXII.-Sèvres._Ovoid Vase . . . . . . . " 148

XXIII.-Sèvres.-Vase with Royal Arms . . . " " 162

XXIV.-Sèvres._Vase "Cassolette" . . . . . " $\quad 168$ 



\section{LIST OF \\ BLACK AND WHITE ILLUSTRATIONS.}

FIG.

1.-Rouen.-Mustard-pot, painted in Blue

To face page

2.-Rouen.-Cup decorated with "Lambrequins" . . . . 16

3.-Rouen (?).-Flower-pot . . . . . . . . 18

4.-St. Cloud.-Milk-jug . • . • . • • . . 22

5.-St. Cloud.-Jug mounted with Silver . . . . . 24

6.-St. Cloud.-Flower-pot . . • . . . . . . 26

7.-Chantilly.-Chinese Figure and Vase . . . . . . 32

8.-Chantilly.Jug . . . . . . . . . . 32

9-10.-Mennecy-Villeroy--Rustic Figures . . . . . 34

11.-Mennecy-Villeroy.-Teapot . . . . . . . . 36

12.-Vincennes.-Bouquet of Flowers . . . . . . . 42

13-14.-Vincennes.-Flower-pots . . . . . . . . 44

15.--Vincennes.-Bouquet of Painted Flowers . . . . . 46

16.-Vincennes.-Vase, with Flowers in Relief . . . . . 48

17-18.-Sèvres.--Soup Tureen and Stand . . . . . . 54

19.-Sèvres.-Jardinière, with green ground . . . . . 60

20-21.-Sèvres.-Covered Bowl and Stand . . . . . 66

22.--Sèvres.-Jardinière, with rose-Pompadour ground . . . 66

23.-Sèvres-Ewer and Basin . . . . . . . . 80

24-25.-Tournay.-Sugar-box and Cream-jug . • . . . 86

26.-Sèvres.-Escritoire inlaid with Porcelain Plaques . . . 94

27.-Sèvres.-Dish, with Arms of Emperor Paul of Russia • $\quad$ • 96

28-29.-Sèvres.-Plates, decorated by Ledoux and Buteux . . 98

30-31.-Sèvres.-Cup and Saucer . . . . . . . 106

32.-Sèvres.-Biscuit Figure : "The Washerwoman" . . . 108

33.-Sèvres.-Biscuit Figure : "The Singer, Dubarry" . . . 110

34-35.-Sèvres.-Biscuit Statuettes . . . . . . . 112

36.-Sèvres.-Biscuit Group : "The Alpine Shepherdess" . . 112

37.-Sèvres.-Biscuit Group : "Sancho Panza" . . . . 114 
FIG.

38.--Sèvres.-Biscuit Group : "Beauty Crowned" . . . . 114

39.-Strasburg.-Soup Tureen . . . . . . . . . 116

40-41.-Niderviller-Cup and Saucer . . . . . . 118

42.-Niderviller.-Jug and Basin . . . . . . . 120

43.-Lille.-Jug . . . . . . . . . . . . . 122

44.-Caen.-Milk-jug . . . . . . . . . . . . . . 124

45.-Limoges.-Plate .

46.-Marseilles.-Dish . . . . . . . . . . . 126

47.-Paris (Faubourg St. Denis).-Bust of Mirabeau . . . 130

48.-Paris (De la Courtille).-Vase . . . . . . . . 132

49.-Paris (De la Courtille).-Marbled Vase . . . . . . 134

50-51.-Paris (Rue Thiroux).-Covered Bowl and Stand . . . 136

52.-Paris (Rue Thiroux).-Water-jug and Basin . . . . 136

53.-Paris (Rue Thiroux)-Covered Cream-jar . . . . . . 136

54.-Paris (Fabrique Duc d'Orléans).-Vase . . . . . . 138

55-56.-Sèvres.-Cup and Saucer . . . . . . . 146

57.-Sèvres.-Plate . . . . . . . . . . 152

58.-Sèvres.-Milk-jug • • . . . . . . . . . 154

59.-Sèvres.-Vase $\quad . \quad$. . . . . . . . . . . . 156

60.-Sèvres.-Vase . . . . . . . . . . . . 158 


\section{FRENCH PORCELAIN.}

\section{CHAPTER I.}

\section{THE INVENTION OF PORCELAIN IN FRANCE.}

THE story of the invention of porcelain has often been told, 1 but no account of the history of French porcelain would be complete without some reference to the general history of porcelain in Europe. It is impossible for anyone but an expert or a connoisseur to realise the long and sustained efforts that were necessary before it was possible to reproduce in Europe a material so fine, so delicate, and so precious as Oriental porcelain.

Previous to the reign of Louis XIV. nothing was known in France of any other porcelain than that which came from the Far East-from China and Japan. A few pieces of the soft Florentine porcelain, made under the patronage of the Medicis, doubtless found their way to the court, but they must have remained unknown elsewhere. This soft porcelain, whether made in Italy or in France, was the natural step by which the faïence-makers of those countries strove to bring the ware with which they were perfectly familiar into cioser agreement with the new and marvellous pottery of the East. It will be shown farther on that the technique of true porcelain approaches in many ways to that of simple faïence. At all events, it was the fairence-makers in both countries who had the first success in making a material that could in any respect be compared with Oriental porcelain. 
It has been well established that during a period of at least one hundred and fifty years several tentative efforts at the manufacture of translucent pottery were made in Italy; not without interruption it is true, for the invention seems to have been made and forgotten, and made again. Baron Davillier has recorded in his book- "Les Origines de la Porcelaine en Europe"-the experiments made in Venice at the end of the fifteenth and the beginning of the sixteenth century, the more successful efforts of the Duke of Este and Ferrara, and, finally, Florentine productions of the sixteenth century, which have been already referred to.

These pieces of Medicean porcelain, so highly treasured by the museums and the great collectors for their rarity, are not remarkable for their quality as porcelain; the glaze is seldom very brilliant, the body is only moderately translucent, and the colour of the whole is somewhat dull and yellow. The precious little collection in the Victoria and Albert Museum will allow the English connoisseur to appreciate the artistic merits of its blue and white decoration, even though the pieces themselves are rather thick and clumsy in manufacture.

Scientifically speaking, the mystery of porcelain was not truly solved by these experiments of the faience-makers, the glassmakers, and the alchemists. What they tried to reproduce was the true Oriental porcelain; that material so fine and so precious, so delicate to the touch, so mysterious to the eye, that it was imported into Europe and sold at enormous prices in spite of unheard-of difficulties; what they did produce was a fine species of glass, possessing something of the same aspect.

Even as early as the fourteenth century one finds some mention of Oriental porcelain in the inventories of the possessions of kings and great nobles, but as the word "porcelain" was at this time very loosely and unscientifically applied, it is not until the reign of Charles VII. that we find anything really reliable under this head. There is a passage of Mathieu de Coussy, the historian of Charles VII., dating from the year 1447, where he speaks of a letter addressed to the Sultan of Egypt, or of "Babylon," that he would favour French commerce in the 
seaports of the Levant. The letter finishes with these words :"Si te mande par le dit Ambassadeur un présent à savoir trois escuelles de pourcelaine de Sinant, deux grands plats ouvertz de pourcelaine, deux touques * verdes de pourcelaine, deur bouquetz $\dagger$ de pourcelaine ouvré, \&c."

One realises the value attached to objects of porcelain at this period when they were thus solicited as presents from one monarch to another. It may be safely said that from this time (the middle of the fifteenth century) Oriental porcelain was collected and treasured by the crowned heads of Europe. Francis I. possessed, in his room of curiosities, "vases and dishes of porcelain, curiously wrought," as we find by an inventory of the year 1586.

At this period the entrepôt for such Oriental porcelain as came to Europe was Cairo, then one of the greatest centres for the exchange of the products of the East and West. The precious porcelain was brought overland to the bazaars of Cairo, and thence it was shipped to the ports of the Mediterranean, as we know through an author of the end of the sixteenth century, Loys Guyon, who, in a chapter entitled :- " Qu'est la Vaisselle de pourcelaine; d'où elle s'apporte; et comme elle se fait," tells us that in Cairo the faïences of Sicily, of Naples, and other places are sold at very moderate prices, while Chinese porcelains are held in the highest favour. This favour evidently extended to England as well as to France. Does not the Victoria and Albert Museum possess a magnificent octagonal ewer of blue and white porcelain, the spout of which is joined to the body by a richly ornamented neck? On this ewer a grotesque Chinese figure, painted in blue under the glaze, shows to the full the quality of the material, while, finally it is mounted with a silver mount bearing the hall-mark of the year 1585 . We may judge of the importance attached to this piece of porcelain by its English owner of the sixteenth century, from the care with which he had it mounted with a most beautiful and characteristic example of the silversmith's work of the period.

(*) Touque. Vessel-oval vase.

$(\uparrow)$ Bouquet. Bottle with handles. 
Throughout the seventeenth century, though the imports of Oriental porcelain into France and England were largely increased by the development of trade consequent on the opening up of the Cape route to India, Oriental porcelain still remained a rarity, as is attested by the high value put on such pieces as we find specifically mentioned in contemporary documents. But the introduction of Chinese porcelain in larger quantities led to a distinct trade in it which has continued to our own times. As early as 1660 there were in Paris a number of merchants dealing in fine porcelain; collectors and amateurs were already numerous; yet so great was the mystery connected with this unique material that all the authors of the period seriously declared that porcelain must remain a whole century embedded in the ground to reach its beautiful texture and gloss. There existed, in the Palace of Versailles, a Chinese room, or porcelain room, where porcelain given to the King, or acquired by his privy purse, was kept. This collection was greatly enriched in 1686 when the ambassador of the King of Siam delivered, with great and solemn pomp, the presents which his Majesty had sent to Louis XIV. and some of the princes and nobles of his court. Among these presents were a great number of magnificent specimens of Oriental porcelain, many of which are to be found to-day in museums and collections, elaborately mounted in French metal-work of the period. On some of these metal mounts stamped decorations of "suns" and "fleurs-delys" will be found which correspond with the descriptions given in the inventory of the Royal pieces drawn up in 1686 by the Jesuit Father, Tachard.

It is no surprise to find that throughout this period ceaseless efforts should have been made to imitate a material so highly prized. We have already mentioned the apparent success that attended upon these efforts in Italy; and in Nevers as well as in Delft, in Rouen as well as in Italy, one potter after another strove to rival and imitate the white plates and vases, with decorations in blue and in polychrome, that had found their way from the East. It must be remembered that even by the second half of the seventeenth century pottery was not in common use 
in Europe. Doubtless, the art of working in clay had been considered too clumsy and too rude to entitle it to extensive use in the decoration of churches, or for the production of the rich accessories used in ceremonial observances. In fact, all the pyxes, the vessels, the crosses, the shrines, and the ornamental plate, used in the services of the church, were of gold and silver, often covered with enamels. When we recall the efforts that were made at this period for the adornment of places of worship with the most noble and precious materials, we realise the importance that was attached to the making of enamels at Limoges, and the relative worthlessness of the pottery of the period. If the Church that, by its demands, has created and developed so many branches of industrial art in France, did not esteem pottery as a fine art, then the nobility, and even royalty itself, were likely to have little use for it either. In every rank and class of French society dishes of gold, silver or pewter were employed for daily use. Ultimately, general misery and prolonged and wasteful wars made the silver plate disappear from the tables of the wealthy, and on two occasions, first, after the war of 1691, and, secondly, after the famine of 1709, the King and the nobles sent their plate to the Mint in order to procure needful supplies for the service of the court. Thus it was that dire necessity finally led the French nobility to patronise the art of the potter, and the great development that took place in French faïence at the commencement of the eighteenth century was caused, not so much by the love of art as by the necessity of providing a substitute for the plate that had been melted. It should be added that if the clergy and the nobility had displayed little interest in the development of decorative faïence, the lower orders were content with the most vulgar dishes of clay, more or less badly glazed, with galena glaze, like the common crocks usedi all over Europe. It is singular that the disasters of the French State at the end of the seventeenth century, due to the unlucky politics of Louis XIV., should have been necessary to establish the French ceramic industry, which was to reach such a remarkably high development before the close of the eighteenth century; and with this development of the 
painted faïence of France came repeated efforts to manufacture porcelain.

By this time the various Indian Companies had imported into Europe vast quantities of Japanese and Chinese products. A Portuguese mission having stranded in 1542 on the coasts of the Island of Kou-Siou were most hospitably entertained by the Japanese, who called them their fellow-countrymen. This mission obtained commercial rights, and the Portuguese were allowed to establish warehouses in Nagasaki. They were soon followed by the Dutch, who, for more than a century, maintained a monopoly of trading with Japan. The Portuguese had, however, the idea of introducing Catholic missionaries, to whom the population listened with interest. Then followed the excesses of the propaganda, and political and religious difficulties arose, so that the Japanese were driven to expel the foreigners and prosecute those who believed in their new doctrines. In 1639 an Imperial edict was promulgated which expelled the foreigners-priests and merchants, laymen and missioners, alike -from the Islands of Japan. This exclusion was rigorously maintained against the Portuguese and the missionaries, but the Dutch were granted certain exemptions. They were allowed to establish in an islet near the port of Firando a station called Decima, or Deshima, and it was from this place that the Dutch Indian Company carried on their trade as before. It was from this entrepôt that they brought, between 1698 and 1722, a series of porcelains, from which were chosen the magnificent pieces now to be found in the Japanese Museum at Dresden.

While the Dutch had their centres of commerce, first at Nagasaki, and afterwards at Decima, the other European nations soon strove to obtain a share of the commerce of the East. Of the various Indian Companies that were formed for the purpose, the English East India Company, organised at the commencement of the seventeenth century, soon began to make its power felt. As the Dutch and the Portuguese were at this time supreme in the Far East, the English company helped Shah Abbas, the powerful and enlightened ruler of Persia, to expel the Portuguese from the port of Ormuz. By this means they 
were allowed to establish themselves at Gombroon on the Persian Gulf, where they soon built up a considerable trade, Gombroon being a natural warehouse for Europe, the Indies, and China. From Gombroon, Chinese porcelains were sent to England, where they acquired the name of Gombroon ware, the common title used for Chinese porcelain down to about 1640 . At about that time the English company obtained a settlement in Canton, and the appellation was slowly changed from Gombroon ware to China ware. It was by way of Gombroon that the Persians obtained their Chinese porcelain decorated after the Persian taste, beautiful collections of which are to be seen in the British Museum, as well as in the Oriental section of the Victoria and Albert Museum. In the beginning, of course, the various European trading companies took from the Chinese their native porcelain, of true Oriental form and decoration, but throughout the eighteenth century and even earlier, European patterns were sent to the East to be copied or imitated in porcelain by the potters of Canton or King-te-Ching, of Hizen or Nagasaki. Occasionally we find rude imitations of European statuettes, as, for instance, the equestrian statue of Louis XIV. which has been found in Chinese porcelain; or the large vases bearing the arms of the Royal family of France, or of the Princes of the Houses of Bourbon, Orléans, Condé, \&c. We may still find whole dinner services, or portions of dinner services, or flower-pots bearing the coats-of-arms of less distinguished families, or even simple badges or emblems.* Most amusing of all is it to find careful and elaborate copies, painted by hand, of some European engraving, used to decorate plates, dishes or cups for a European patron.

It will thus be perceived that when French potters turned their attention to the manufacture of porcelain they had many competitors already in the field. In the first place there was the large and growing importation of true Oriental porcelain, and in addition there was the manufacture of Italian, Dutch and French faience. When we add to this the absolute ignor-

* The English collector will immediately recall the so-called "Lowestoft" hard-paste porcelain.-ED. 
ance of all Europeans as to the technique of Chinese porcelain, of which such ridiculous and wonderful stories were current, we cannot but admire the courage, and applaud even the partial successes of those experimenters who were at work striving to produce a European substitute for this wonderful Eastern substance.

There are, in fact, two different ways of making what may be called "Porcelain": one way is by attempting to make a transparent pottery from natural materials; while, commencing from the other end, it is possible to produce a devitrified glassy substance and to coat this with a transparent layer of a soft glaze rich in lead. If we replace the ordinary clays which form the bases of faïence or earthenware with earthy mixtures which are white and fusible, a species of porcelain is produced which can be covered with glaze; such a material is the true porcelain of the East. If, on the contrary, we first of all prepare a frit, which is a glass having only a limited translucence, and then agglomerate this frit with a small proportion of plastic material (either clay marl or organic substance), such a mixture fired to the "biscuit" condition, and then covered with a rich lead glaze, forms the true soft porcelain. Throughout the seventeenth century the only clays known in France were those found in the neighbourhood of Rouen, Nevers, Lisieux, and Paris; the occurrence, and even the nature, of kaolin and the kaolinitic minerals - the only bases of true porcelain - remained unknown; it follows, therefore, that the latter of these methods was the one first resorted to in France for the production of porcelain.

It was the faïence-makers, who, after long and consistent experiment, had the merit of developing in France the manufacture of this soft porcelain, an industry eminently French, which rendered the eighteenth century illustrious with the oftrepeated names of Rouen, St. Cloud, Chantilly, Mennecy-Villeroy, Vincennes, and, above all, Sèvres, where the manufacture of softpaste porcelain attained such a prodigious development. This, soft-paste porcelain had a very special technique, which rendered its production a matter of the utmost delicacy. If we follow the 
PLATE II.

\section{CHANTILLY}

(PÂTE TENDRE, ABOUT 1760).

Flower-holders in the form of Statuettes, Wrth Painted Decorations in the Kakiyemon Style.

Victoria and Albert Museum.

(By kind Permission of J. H. Fitzhenry, Esq.) 

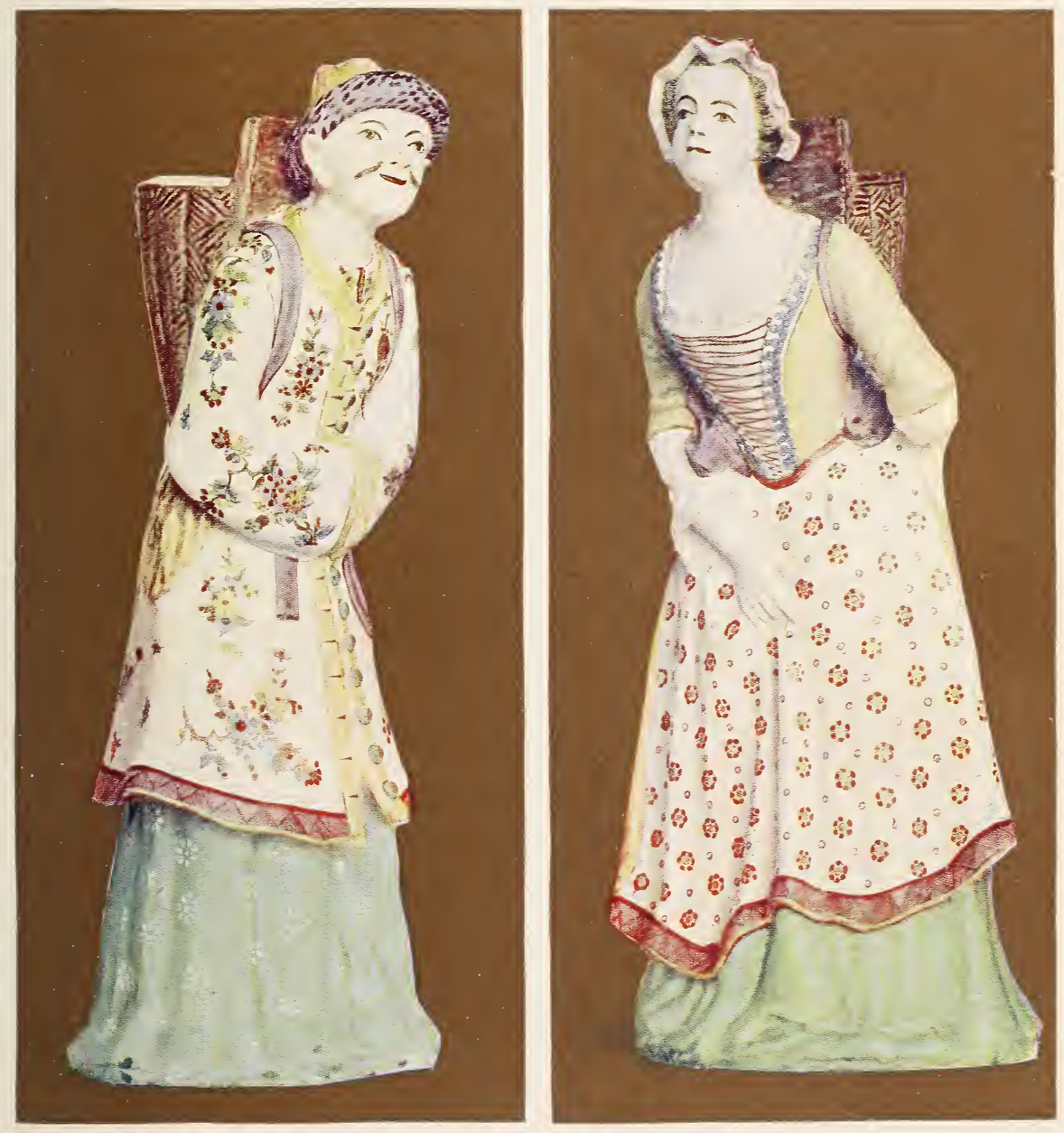

contemporary authorities who have written on this question, and who had full knowledge of the manufacture of soft paste, we understand that they commenced by making a frit. This frit almost always contained natural earths and alkalies, and alkaline-earths such as lime. To give an example, it would be necessary to melt together, at a sufficient heat, siliceous sand, alum, sea-salt, gypsum, soda and nitre; the fusion taking place in the bottom of a furnace where porcelain or faïence was fired, or, sometimes, in a special furnace built for the purpose. This frit was pounded and washed with boiling water to remove any materials which remained soluble. The working clay was then prepared by adding to this frit a small portion of calcareous marl, which, as its name implies, was a mixture of chalk and plastic clay; sometimes pure chalk was added in addition. This mixture was ultimately ground together in water, and gave a paste which had little plasticity, and was so very difficult either to "throw" or to mould that it was necessary to add to it certain organic substances, such as black soap or parchmentsize, to render its manipulation possible.

The moulds used for shaping the pieces were of plaster, of considerable thickness, and so contrived that they gave the outer shape to the vessel; another mould or core of plaster gave the inside shape, and was pressed into position by means of a mechanical press worked by a lever.

The pieces thus moulded were first dried, and were then turned on a lathe to reduce them to the proper thickness. The handles, or other ornaments in relief, were applied in the same way as is common with other species of pottery, by the use of slip to act as a lute. The pieces thus fashioned received their first or "biscuit" fire, and this was the most difficult part of the whole process. First of all it was necessary to support all the round or projecting parts with little props or supports of the same material, for during the firing it was necessary to reckon on two conditions which mightlead to the deformation of the piece: on the one hand the softening of such a highly vitreous substance, and on the other hand, the shrinkage due to the diminution in bulk of the whole piece. As the props or supports must 
be made of the same material as the piece itself, a little powdered sand was used to prevent actual contact. The firing was done in saggers made from calcareous marl, in ovens similar to those used by the faience-makers. These ovens were divided into two chambers one above the other; in the lower chamber the "biscuit" ware was fired, and in the upper chamber the saggers only were fired. Under the lower chamber, in the bottom of the furnace, was formed a circular opening into which the flames came direct from the firing mouths, and here it was that the frit itself was melted. These ovens appear to have fired in a very irregular manner and were difficult to manage, so that a large proportion of the pieces came out from the first firing in an imperfect condition; some being too much softened and vitrified by excessive heat, while others would be rose-coloured, grey, or blackened from insufficient firing and penetration of smoke. Aspen wood was used as fuel because it gave a clear and steady flame, the fire being maintained from seventy-five to one hundred hours. It was necessary to burn from thirty-two to forty cubic metres of wood to fire an oven of this type having only about ten cubic metres of useful space, so that the necessary fuel formed no inconsiderable portion of the expenses of the process.

When the "biscuit" was drawn from the oven, the supports were removed, the whole piece was rubbed with sand to clean the surface, and was then coated with glaze by sprinkling with a brush, in the same way that glaze was applied to faience. The glaze used was nothing but a fusible glass very rich in lead, finely ground, and suspended in water. The glaze-coating was then melted by firing the piece a second time in a similar oven to that already described, but this firing was completed in from twenty-five to thirty-five hours, the temperature required being only such as would bring the glaze to its point of fusion. It was frequently necessary, in order to obtain a perfect glaze-coating, to give the piece several coats of glaze, firing it afresh each time. In some factories the glazed pieces were fired in the upper chamber of the oven, while the "biscuit" pieces were being fired in the lower chamber; but in any case the glazed pieces were 
always fired in saggers well washed inside with the same glaze, so that the sagger itself might not impoverish the glazed surface by absorbing some of the oxide of lead from it.

Such a procedure as that above described is extremely complex although we have dealt merely with the shaping and glazing of the ware, and have not considered at all the important questions of decoration and painting. If we reflect that at this period the chemical industry did not exist, so that every fresh supply of the materials might have a different composition, and that the knowledge of the clays and other natural substances used was also in its infancy, we can realise that the potters of the eighteenth century found in their materials alone a constant source of trouble and of failure. When we reflect further on the numerous difficulties of shaping a material that was not plastic, and of firing a substance so liable to go out of shape within a very few degrees of heat, we begin to understand and appreciate why the French soft porcelains are so much sought after and so highly valued by collectors.

It would, perhaps, be unreasonable to value this material merely because of the difficulty of its fabrication, but when we find how those difficulties were overcome, and that in spite of them porcelains were produced with such freshness of colour, such beauty of texture, and such quality of surface, we can realise more fully the special charm of this fine and precious material. Besides all this the French soft porcelains, in the richness and variety of their decorations, afford most valuable testimony with regard to French art and French taste under Louis XV. and Louis XVI. Here we find French decorative art under its most varied aspects : sometimes frivolous, sometimes severe, but always bright, gay and accomplished. From the soft porcelain alone, by a study of its forms, its decorations, and the caprices of fashion that dictated them, it is possible to obtain a clear impression of the France of the period.

In conclusion it should be pointed out how far removed the French soft porcelain was from the true porcelain of the East which had been the starting point of its manufacture. The porcelains of China and Japan made only of natural clays and 
rocks, are much more analogous to faïence, which is also made of purely natural materials, than this soft-paste porcelain which approaches technically to glazed glass, and may indeed be said to form a connecting link between pottery and glass. While the porcelain of the East therefore deserves its name of natural hard porcelain, no term can be more exact than that of artificial soft porcelain which has been applied to the material we are now discussing. 


\section{CHAPTER II.}

FIRST ESSAYS IN PARIS, AND FIRST SUCCESSES IN ROUEN.

IT has been already stated that it was reserved for the makers of faïence and of glass to win the first successes in the manufacture of porcelain.

About the year 1690 there appear to have been made at the glass factory of Sieur Perrot, at Orléans, some articles in a dull, milky glass simulating the appearance of porcelain. The museum at Sèvres possesses a snuff-box of this kind, the moulding and the polish of which have evidently been obtained by the use of the lapidary's wheel. It is, in a word, cut enamel. Elsewhere in France, as well as in Holland, milky or porcelainlike glass was being produced, but these productions cannot be confounded with porcelain. We may mention that in 1686 Sieur Mazzolay de la Motte had obtained a privilege for the manufacture of glass wares at Paris, with the intimation that he manufactured porcelain and materials imitating agate.

It was in 1664 that Louis XIV. granted Claude Réverend, a merchant and citizen of Paris, who stated that he possessed the secret of making faïence and imitating porcelain as beautiful, and even more beautiful, than that which comes from the East Inclies, authority to make the afore-mentioned porcelain in Paris, and in such neighbouring places as he might think suitable. Réverend was also allowed to import into France a stock of these pieces which he claimed to have made in Holland. The monopoly of this manufacture and importation was granted to him for the term of fifty years, and everybody was forbidden, 
under pain of confiscation of their goods and a penalty of 10,000 livres, to make or sell this porcelain within thirty miles of Paris.

It is impossible to be certain what Claude Réverend really manufactured in Paris, and whether, indeed, he was more than a dealer who imported into Paris the famous Delft wares of Holland, which at this period so wonderfully reproduced the Oriental blue and white porcelain,* neither do the slight references by contemporary authors help us very much. Savary des Bruslons $\dagger$ says that experiments in the manufacture of porcelain were first made at Rouen, and improved upon at Passy, near Paris, and at St. Cloud; and he further remarks that in order to equal Chinese porcelain the French porcelains need only to have been brought 5,000 miles and passed off as foreign to win the minds of a nation accustomed to esteem what it does not possess and to despise what it finds in its own land.

Another author, the editor of the "Dictionnaire Manuel de l'homme du Monde," declares that in beauty of grain, perfection, and finish of the pieces, accuracy of design and brilliancy of the colours, at least of the blue tints, the French have been but little surpassed by the Chinese. Finally, according to an English work, the "Cyclopedia or an Universal Dictionary of Arts and Sciences," it is stated that the great defect of the French porcelains lies in the colour of the clay, which can be easily distinguished from the vivid and pure white of the Chinese by its generally dull and dark appearance.

It would certainly be difficult to maintain that such evidence as is here cited proves the existence of a porcelain factory at Paris or at Passy, as some authorities have maintained, but it may be remarked that a few pieces are known in museums and private collections that can with difficulty be attributed to Rouen or St. Cloud, and which may conceivably be of Parisian origin, and of this earlier date.

There are, for instance, in the ceramic museums at Sèvres and Limoges two salt-cellars, the paste of which is dull and heavy,

* See Solon's " Old French Faïence," p. 75.

† "Dictionnaire Universel du Commerce." 


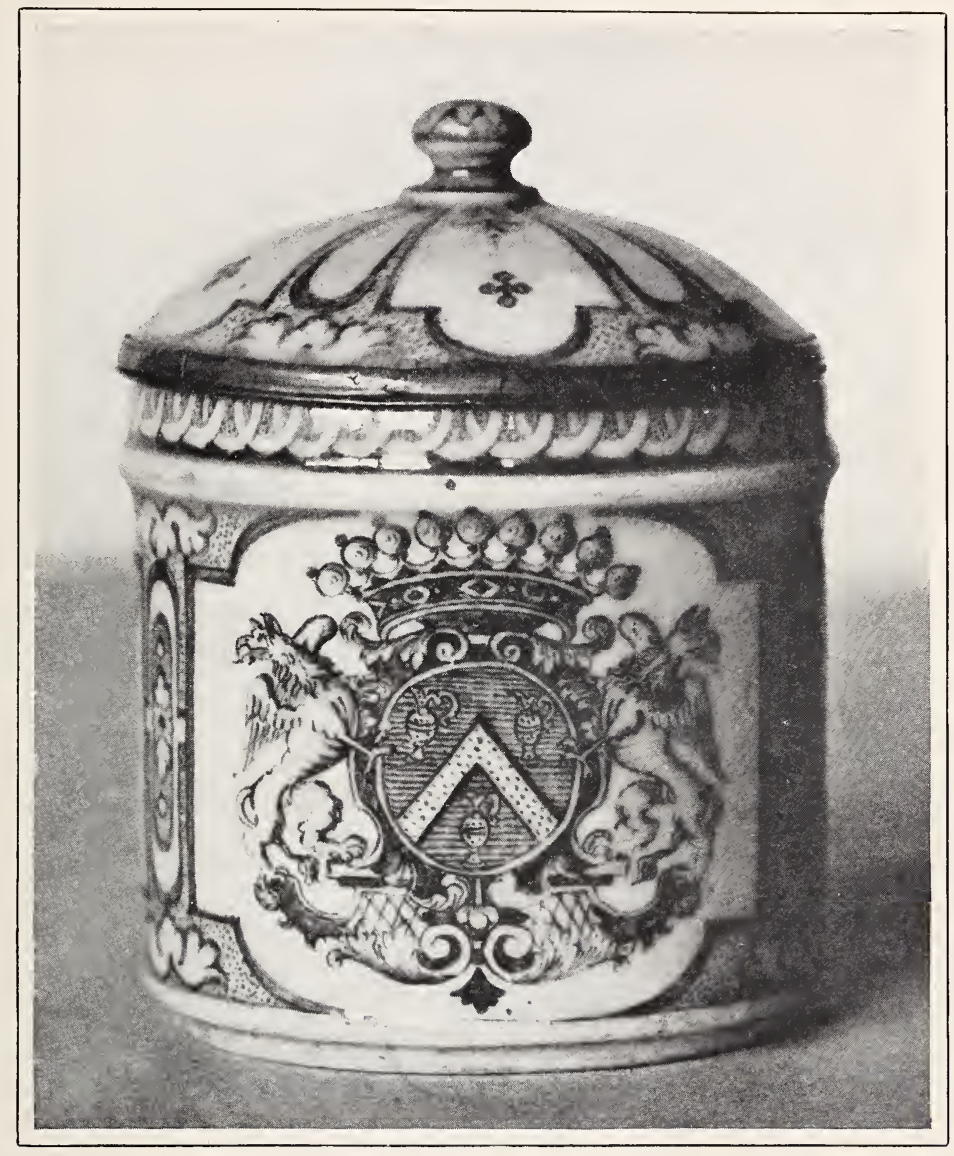

ROUEN (Pâte tendre).

Fig. 1.-mustard POt Painted in blue.

H. $3 \frac{1}{2}$ in.

Sèvres Museum. 

and the forms absolutely like those found in the faïence of the period, while the blue decoration is also analogous to contemporary Parisian faïence. The pieces give every evidence of having been made by faïence-workers little accustomed to a material so deficient in plasticity as the paste of soft porcelain, for the pieces are fractured, as they would be by imperfect manipulation in the clay, as well as by imperfect firing. The partitions of the salt-cellars have bent, the extremely vitreous glaze has in places run into streaks or drops; in a word, everything about the pieces manifests the inexperience of the makers, just as truly as their decoration proves their French, and, one may almost say, their Parisian, origin. The very care with which these pieces, marked "A. P.," with a star above the letters, must have been preserved that they should have descended to our time, shows the interest attached to them by their original possessors. In the absence of documents, or of pieces marked and dated, it is impossible to form any decided conclusion as to the origin of the pieces here described, but it is just possible that they may have been the initial experimental pieces by which Réverend or some similar person sought to support his claim for the grant of letterspatent. But even if we grant that Réverend experimented to this end, we have no proof that he ever established a factory.

It is only in 1673 that we reach sure ground, when Louis Poterat, a faïence-maker of St. Sever, near Rouen, applied for and was granted an exclusive monopoly for the fabrication of plates and dishes, pots, and vases of porcelain like that of China, and of faïence after the Dutch fashion, for the period of thirty years. Louis Poterat was granted this privilege on the ground that, by travelling in foreign countries and by continual diligence, he had found those secrets so important for the establishment of a new industry in France. It is singular that the letters-patent granted to Poterat for the manufacture of porcelain made no mention of the grant made nine years previously to Claude Réverend for the same purpose. Neither is any mention made of the earlier grant to one Poirel de Grandval for the manufacture of faïence which had already been established at Rouen. Louis Poterat indeed had suggested that in order to 
produce his porcelain it was necessary to fire it along with fairence, and in the more sheltered parts of the oven, as it would not endure the fierce heat required for the faience; and it seems probable that the earlier letters-patent relating to faïence, were deliberately overlooked in order to encourage the production of this wonderful new material-porcelain.

The entire disregard of the patent granted to Claude Réverend would indicate that, as has been surmised above, he contented himself with importing the blue-and-white faience of Delft, and made no attempts to establish a porcelain factory in Paris.

There is some evidence that the soft porcelain of Rouen was made both at the factory of Louis Poterat and of his father Edme Poterat, between the years 1673 and 1696. We gather this from an official inquiry made by M. Lefevre d'Ormesson at the request of M. de Pontchartrain in June, 1694, when the prolongation of Poterat's privilege was sought. This report states that the works at St. Sever (a suburb of Rouen) are well kept, that they possess the secret of making porcelain, but that they make very little of it, but on the contrary manufacture large quantities of faïence. This report further informs us that in consequence of family disagreement the widow of Edme Poterat and her youngest son make porcelain as well as Louis Poterat. It is again explained that this porcelain is fired in the ovens used for the manufacture of faience, and hence the necessity of allowing Louis Poterat to make faïence, although a sole privilege had long previously been granted to Poirel de Grandval for this manufacture. After the death of Louis Poterat, which happened unexpectedly in 1696 , his brother was apparently unable to carry on the works, which were afterwards removed to Rouen, and very shortly the manufacture of porcelain was entirely relinquished.

For a long time the beautiful Rouen porcelains made by the Poterats were overlooked, or confounded with those made shortly afterwards at St. Cloud, though nowadays one wonders that this should have been the case, as there are essential differences between them. 


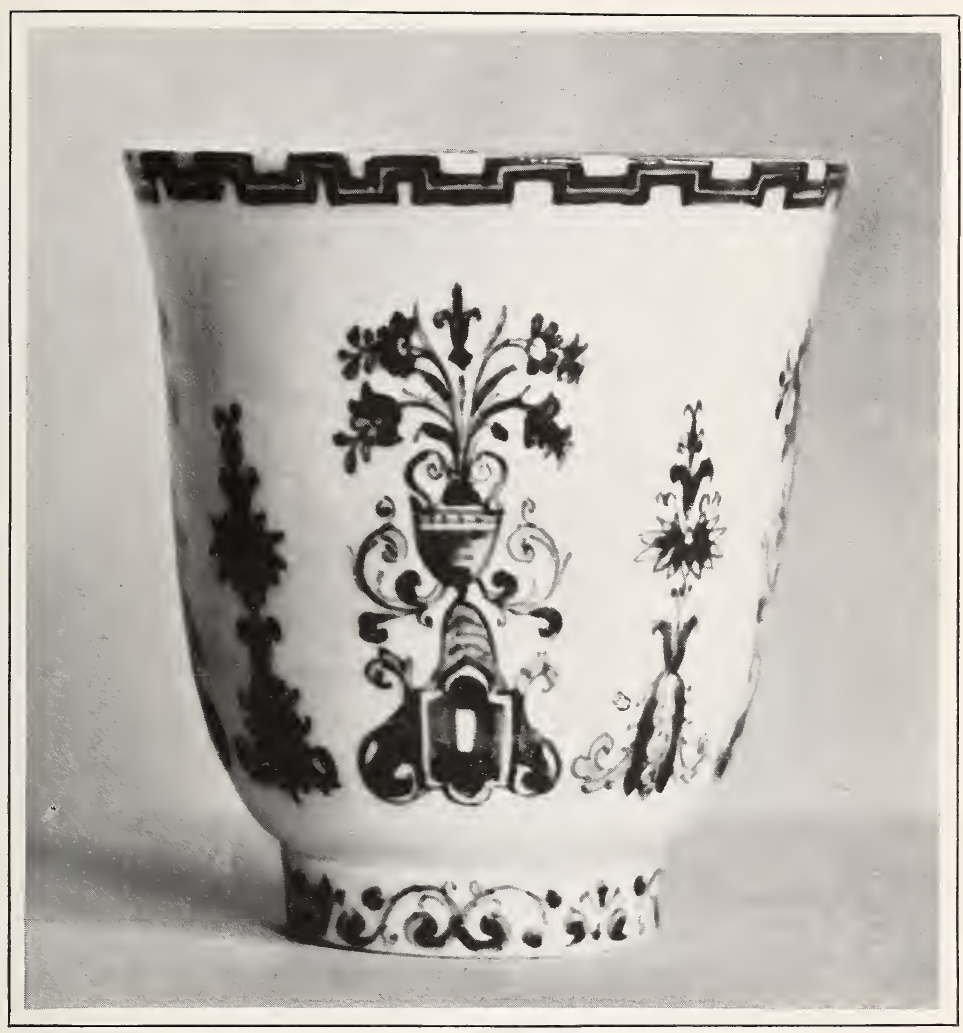

ROUEN (Pâte tendre).

Fig. 2.-CUP Decorated with "LAMbrequins," PAINTED IN BLUE.

H. $3 \frac{1}{4}$ in. Dia. 3 in.

By kind Permission of J. H. Fitzhenry, Esq.

Victoria and Albert Museum. 

A charming example of the Rouen manufacture will be found in the little silver-mounted pot (see Fig. 1) decorated with the arms of Louise Asselin, the widow of a councillor of the Parliament of Rouen.

On comparing such a piece as this with any piece bearing the mark "St. Cloud" we shall be struck, in the first place, with the nature of the paste, which is less amber-coloured than the latter, and indeed possesses a slightly greenish tone. The glaze, too, is less vitreous, and is again of a very pale sea-green tint rather than what one would describe as the "ivory" tint of St. Cloud. Finally the blue colour is darker and more intense, while the manner in which it has been applied bespeaks still more strongly the hand of the faïence-maker. In our opinion the blue of the Rouen porcelain has been painted on the "raw" glaze exactly as was the custom in the manufacture of faïence; while, on the contrary, the blue on the St. Cloud porcelain is distinctly under the glaze, and appears to have been painted on the unfired body, or on the "biscuit," and fixed to it by a low fire before putting on the glaze.

When one is able to see a group of pieces of Rouen porcelain as in the collection of M. le Comte de Chavagnac, which is especially rich in French soft-porcelains, the Rouen pieces immediately strike one by their very slightly sea-green glaze, their rich and creamy paste, less amber-coloured than that of other early French porcelains, and by their blue decoration, which is often darker, and somewhat greyer than that used elsewhere.

The decoration of these pieces is always in the French style of the reign of Louis XIV., and so far as we know there is not a single piece showing decoration directly inspired by Chinese design. Altogether of this rare Rouen porcelain there are only about fifty known pieces, including flower-pots, salt-cellars, and cups. Most of the pieces are decorated in blue only, though there are a few specimens, including one well-known piece in the Rouen Museum, which bear a polychrome decoration in blue, green and red.

In addition to the little silver-mounted pot already referred 
to we also illustrate a cup of Rouen manufacture from the Victoria and Albert Museum (sce Fig. 2), while a third piece is illustrated in Fig. 3.

It must be stated that this flower-pot in the Sèvres Museum is there classified as porcelain of St. Cloud, but by its style and its decoration it seems to us more probably to belong to Rouen. 


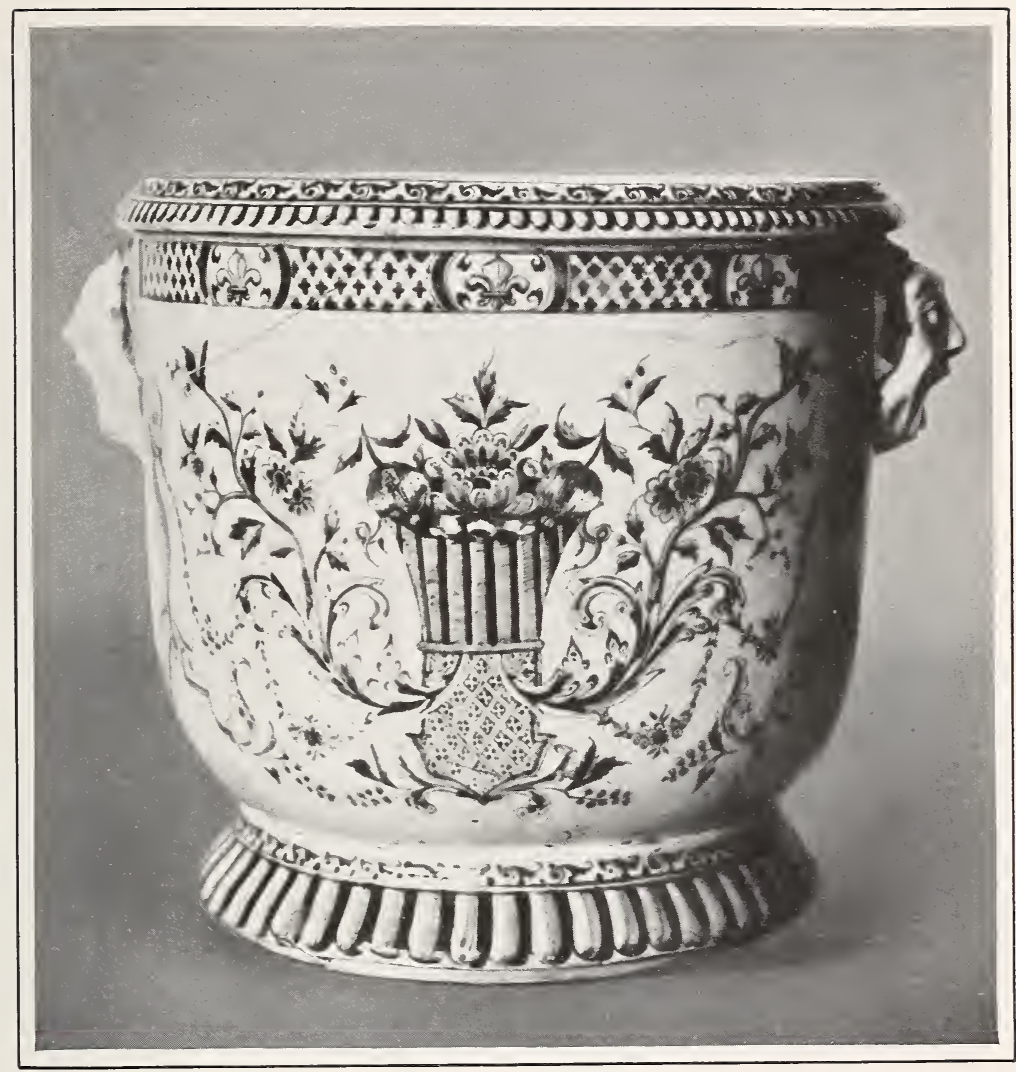

ROUEN (?) (Pâte tendre),

Fig. 3.-FLower-Pot DeCorated in BLUE WITH ROYAL ATTRIBUTES.

H. $8 \frac{1}{2}$ in.

Sèrres Museum. 



\section{CHAPTER III.}

DEVELOPMENT OF THE MANUFACTURE OF SOFT PORCELAIN AT

ST. CLOUD. ITS MANUFACTURE AT LILLE.

IT was long contended that the origin of French porcelain must be traced to the factory at St. Cloud, and to the labours of a faience-maker there named Chicanneau. The priority of the claims of Rouen, however, cannot any longer be contested, and as in the list of faïence painters employed at Rouen given by A. Pottier, the learned antiquary, one finds the same name, Chicanneau, we are tempted to believe that there had been a transference of Poterat's discovery from Rouen to St. Cloud.

The faïence works at St. Cloud appear to have been established before 1670. The factory, near Paris, pnssessed on its own grounds or in its immediate neighbourhood everything that was needed for the manufacture of faïnce-plastic clay, sand, marl and chalk. Its proximity to the famous châteaux of Versailles, Meudon, St. Germain-en-Laye, without mentioning that of St. Cloud itself, was doubtless well calculated to secure for it noble or royal patronage. Modest in its origin, it must have reached a certain assured position of manufacture by 1670 , when Louis XIV. decided to build the Trianon de porcelaine, a little palace that was destroyed in 1687 . The royal accounts for this building, published by Guiffrey, show that Réverend was at that time the principal purveyor of pottery ware to the court, as he supplied in 1670 faïence vases to hold oranges and flowers, the cost of which amounted to 3,319 livres. These vases are further stated to have been manufactured at St. Cloud. 
At this date, 1670, M. Morin was the director of the works, and it was only some years afterwards that Chicanneau and his sons brought the manufacture of St. Cloud faïence to its highest degree of perfection. Only those who have visited the pharmacy of the hospital at Versailles, where a complete set of drugpots made at St. Cloud is preserved, can justly appreciate the beauty of its faience, and the richness of its blue decoration outlined with black.* If the material itself is less perfect than that of Rouen, the decorations are in pure French taste, though the forms have been borrowed from those of China or Japan. We may surmise that Chicanneau, a clever and industrious man who had probably surprised the secrets of Poterat, turned to this St. Cloud manufactory as a suitable sphere where he might develop the fabrication of porcelain on his own account. The first authoritative date connected with the St. Cloud porcelain is the year 1696, as we learn from letters-patent granted by Louis XIV. to "Barbe Coudray, the widow of Pierre Chicanneau, and to Jean-Baptiste, Pierre and Geneviève Chicanneau, brothers and sisters, children of the mentioned Coudray and the mentioned Pierre Chicanneau, and undertakers of the faience and porcelain works established at St. Cloud" . . . in consequence of the statement to the effect that "Pierre Chicanneau, the father, had laboured for several years at the fabrication of faïence, and, having attained a high degree of perfection in this manufacture, had intended to extend his knowledge and to find the secret of making true porcelain; he had made many experiments of different kinds and tried different processes that had produced pieces nearly as perfect as the Chinese and Indian porcelains. The children have continued the same manufacture, and before the year 1696 have arrived at the point of making porcelain of perfect quality."

The letters-patent add that, "Previously a privilege had been granted to the Sieur de Saint-Etienne + to found a works at Rouen, but that the Sieur de St. Etienne had at most only

* See E. S. Auscher. "La Céramique au château de Versailles sous le règne de Louis XIV."

+ The territorial designation of Louis Poterat. 
approached this secret, and had never carried it to such a pitch of perfection or execution as it reached at St. Cloud; that since his death neither his wife nor anybody belonging to his family has made anything in porcelain, and that thus, without wronging the heirs of St. Etienne, it is possible to grant the monopoly to St. Cloud, as much for the good quality as for the beauty and the perfection of the porcelain made by Chicanneau."

We may further remark that among the bills relating to the King's buildings, under the date 1682, there has been found the payment of 3,300 livres to Gabriel Morin for having transported by water from Rouen to Paris 173 boxes, some of them from Rome, and 130 tons of clay for porcelain for His Majesty's service. What this clay was, coming from Civita-Vecchia to Rouen by sea, we do not know, nor what the "Superintendent of buildings, arts, and manufactures" used the clay for, though it is quite likely that it was used by Morin in his faience works at St. Cloud. In any case, as the letters-patent of 1702, above referred to, were only to have effect for ten years, it seems certain that the manufacture had been established before 1696, and though there had been, as we have already seen, earlier attempts in Italy and in France to produce soft porcelain, we must attribute to the St. Cloud potters the first enduring establishment of porcelain-making in Europe.

We have but scanty details of the St. Cloud works in the contemporary memoirs of French writers. The most famous account of the early days of the porcelain works at St. Cloud we owe to an Englishman, Dr. Martin Lister (afterwards physician to Queen Anne), who accompanied the Duke of Portland to Paris at the time of the negotiation of the treaty of Ryswick, and made a stay of some duration in Paris and its environs.

"I saw the potterie of St. Clou, with which I was marvellously well pleased, for I confess I could not distinguish betwixt the pots made there and the finest China ware I ever saw. It will, I know, be easily granted me that the painting may be better designed and finisht (as indeed it was) because our men are far better masters of that art than the Chineses; but the 
glazing came not in the least behind theirs, not for whiteness, nor the smoothness of running without bubbles. Again, the inward substance and matter of the pots was, to me, the very same, hard and firm as marble, and the self-same grain on this side vitrification. Farther the transparency of the pots the very same. . . . I did not expect to have found it in this perfection, but imagined this might have arrived at the Gomron ware; which is, indeed, little else but a total vitrification, but I found it far otherwise and very surprising, and which I account part of the felicity of the age to equal, if not surpass the Chineses in their finest art.

"They sold these pots at St. Clou at excessive rates, and for their ordinary chocolate cups askt crowns a-piece. They had arrived at the burning on gold in neat chequere works. He had sold some tea equipages at 100 livres a sett. There was no moulding or model of China ware which they had not imitated, and had added many fancies of their own, which had their good effects and appeared very beautiful."*

Having quoted this important document we may notice that the château of St. Cloud belonged to the Duc d'Orléans, an enlightened patron of the arts of his day; and that St. Cloud lies on the road from Paris to Versailles, so that it would readily attract the notice of the great lords attending the court. Here is an account of the visit of Madame la Duchesse de Bourgogne on the 3rd September, 1700:- $†$

"I have forgotten to write to you that the Duchesse de Bourgogne, when she had passed through St. Cloud and turned along the riverside to visit Madame la Duchesse de Guiche, made her carriage stop at the door of the house where the MM. Chicanneau have had established for some years now a manufactory of fine porcelain, which without doubt has not its like in all Europe. The princess found pleasure in seeing several pieces of very good shape made on the wheel. She saw some others painted in patterns that were more regular and better done than

\footnotetext{
* "Account of a Journey to Paris in the Year 1698." Dr. Martin Lister. London, 1699.

† Le Mercure Galant, October, 1700.
} 


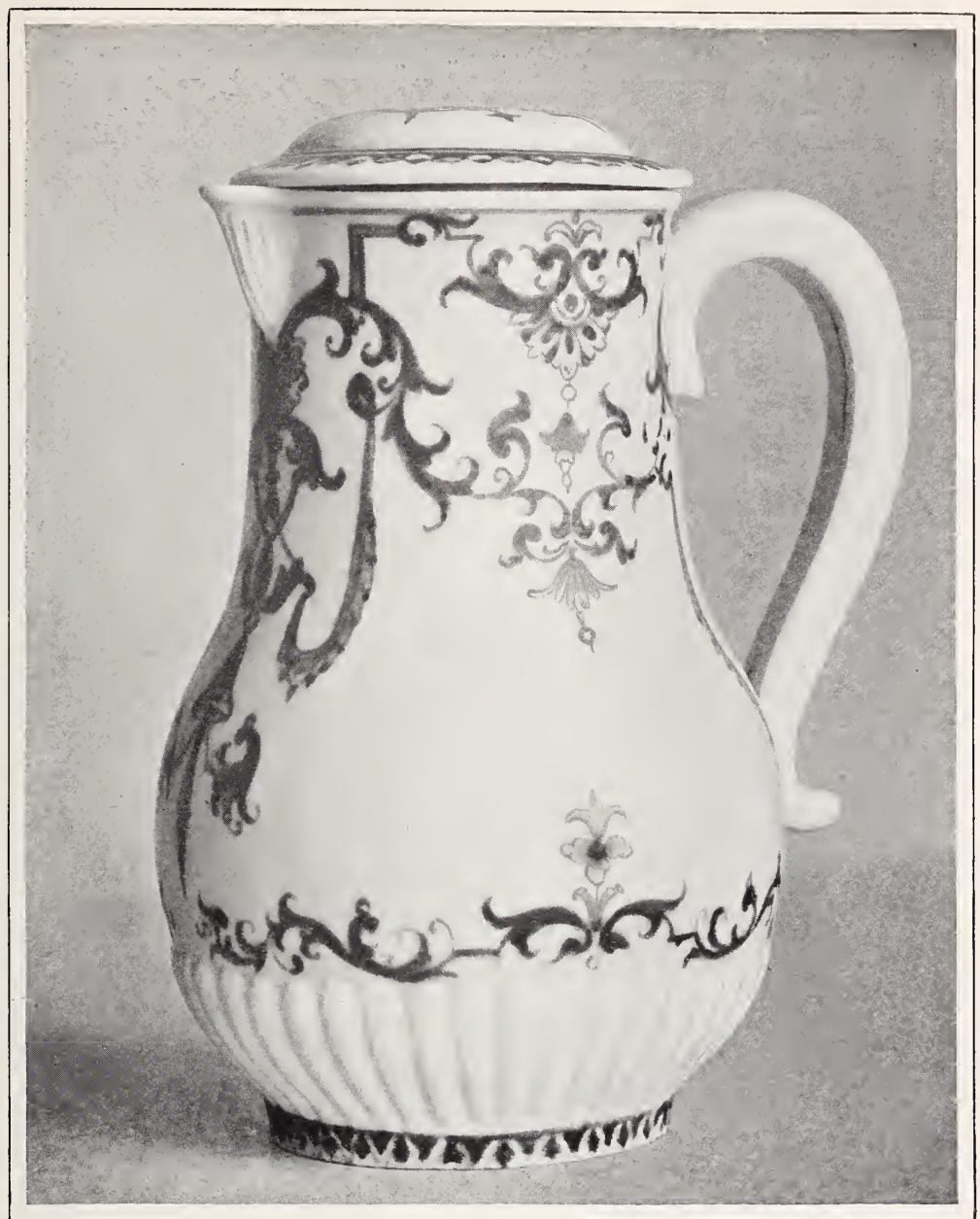

ST. CLoud (Pâte tendre).

Fig. 4. - Milk-JUg With FlUted base aND PAINTED ARABESQUES IN BLUE.

H. $5 \frac{1}{4}$ in. Dia. $3 \frac{1}{2}$ in.

By kind Permission of J. H. Fitzhenry, Esq.

Victoria and Albert Museum. 

those of the Indian porcelain. Then she went to see the fairences being made in the manufactory, and afterwards MM. Chicanneau conducted her into their office, where she saw quantities of fine and beautiful porcelains in their perfection, with which she was so pleased that she promised to come again. She did not leave without shewing her satisfaction by the gratuities she gave to the workmen."

The privilege granted to the factory in 1702 only endured for ten years, and in the fresh letters-patent granted in 1712 for a further period of ten years we find the name of Henri Trou. This Henri Trou, who was Usher of the Antechamber to the Duc d'Orléans, had married, in 1698, Barbe Coudray, the widow of the elder Chicanneau, and had been received into the Company of Master-Enamellers, Glass and Faïence Makers in 1706. The works must have been carried on with considerable success, for in 1722 the privilege was extended to the heirs of Chicanneau and Trou for a further period of twenty years. This third grant of a privilege appears to have been directly due to the Duc d'Orléans, at this time Regent of France, as the King decides "after the opinion of his dear and beloved uncle, the Duc d'Orléans," and gives his decision about the expenditure incurred to bring into use the secrets given by the Duc d'Orléans himself for the perfection of the porcelain. It is a well-known fact that this prince had a laboratory where he studied questions of physics and alchemy, as was the fashionable custom of the day, and where, later on, experiments in the manufacture of hard porcelain were tried.

The decree of 1722 seems to have caused disagreement between the two families concerned. The Trous kept the works at St. Cloud, and Marie Moreau, the widow of the younger Pierre Chicanneau, started a factory in Paris in the rue de la Ville l'Evêque, faubourg St. Honoré. A third factory appears to have been started also in Paris in faubourg St. Antoine, for we read in a memoir of the chemist Réaumur, of the year 1739, entitled "Manière de transformer le verre en une espèce de porcelaine appelée du nom de son auteur porcelaine de Réaumur," the following sentence: "Is it not enough for a 
porcelain that is going to be so cheap if its whiteness is superior to that of our usual porcelains that are made in the faubourg St. Antoine ; if it is just as beautiful as that of the porcelain of St. Cloud; and finally, if its whiteness is not inferior, or is even superior, to that of most Indian porcelain?"

It seems, therefore, certain that at the time that Henri and Gabriel Trou, sons of the elder Trou, and of Barbe Coudray, were carrying on the works at St. Cloud, and some of the Chicanneaus were carrying on the works in faubourg St. Honoré, at Paris, a third porcelain works was also being carried on in faubourg St. Antoine.*

Although further letters-patent in 1742 prolonged the privilege for yet another twenty years, the activity of the heirs of Chicanneau and Trou seems to have been spent in a war of recrimination and legal processes, the details of which are without interest to us.

At what period, or from what causes, the fabrication of soft porcelain at St. Cloud came to an end we do not know precisely, though it has been stated that the works was destroyed by fire in 1773 , and that the proprietors did not possess sufficient funds to rebuild it.

It may be remarked in passing that Dominique Chicanneau is said to have made the first porcelain figures, and "all other kinds of imaginable things," between 1710 and 1724, and that he sold grotesque figures and branched candlesticks in the form of tree trunks as early as 1731 .

The appearance of the St. Cloud porcelain is very characteristic. The paste is decidedly yellowish, and of a fine and regular grain. The glaze is clear and brilliant, with but few bubbles, and very seldom blistered. Sometimes pieces that have been insufficiently fired in the enamel-firing ( $f e u$ de moufle) have dull patches, especially on the flat parts of the pieces.

White pieces with some simple modelled ornament are quite

* François Hébert, who was related to the Chicanneau family, had a faïence factory in the faubourg St. Antoine in 1720. Solon's "Old French Faïence," p. 77.-ED. 


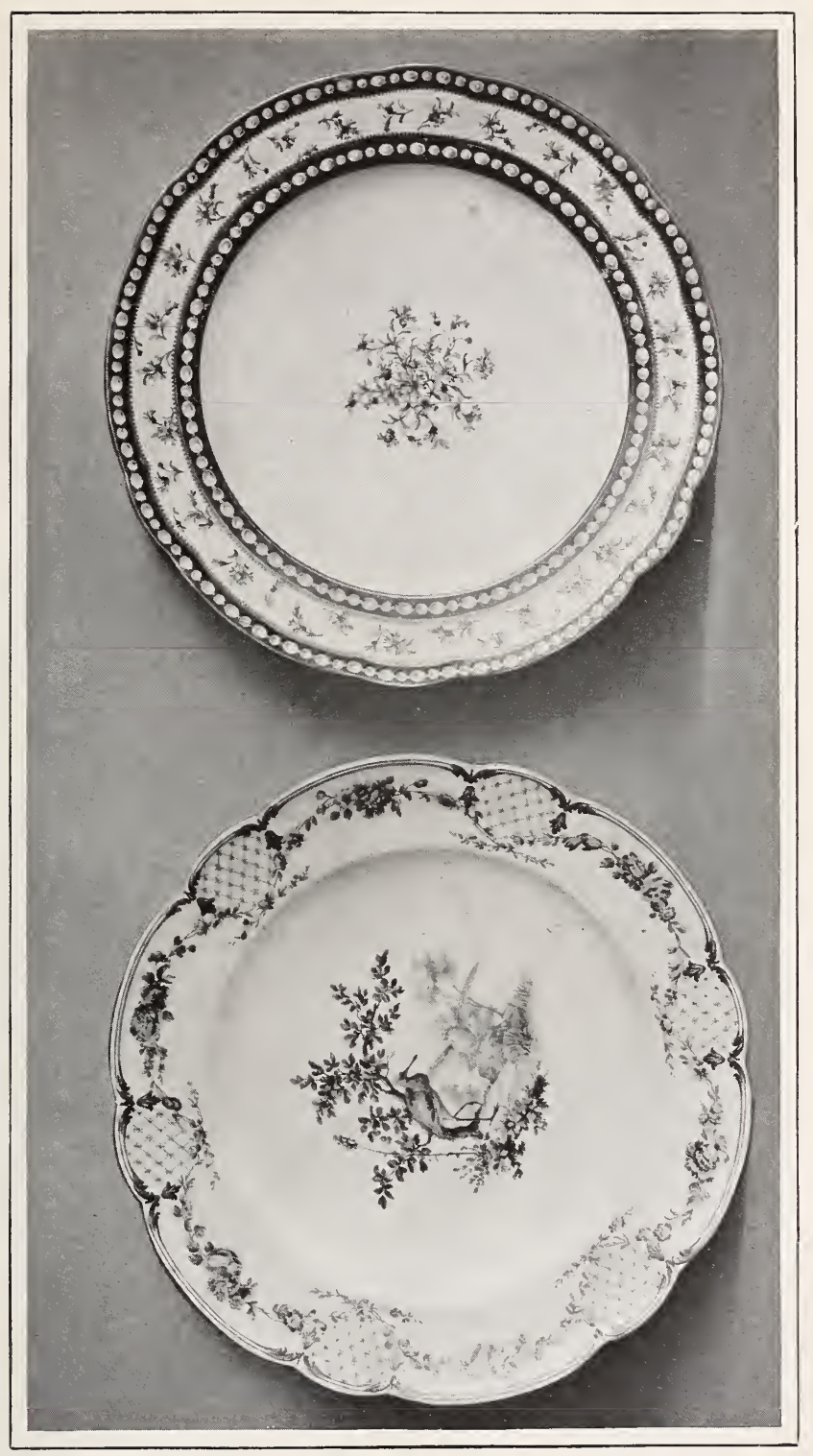

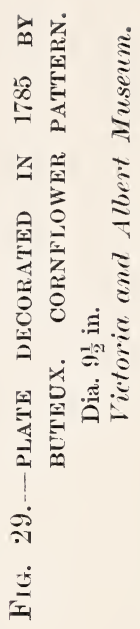

곡

离

安活 至

无宰

오독

然

응

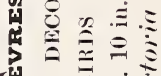

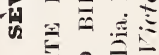

文

ลัง

㝳 



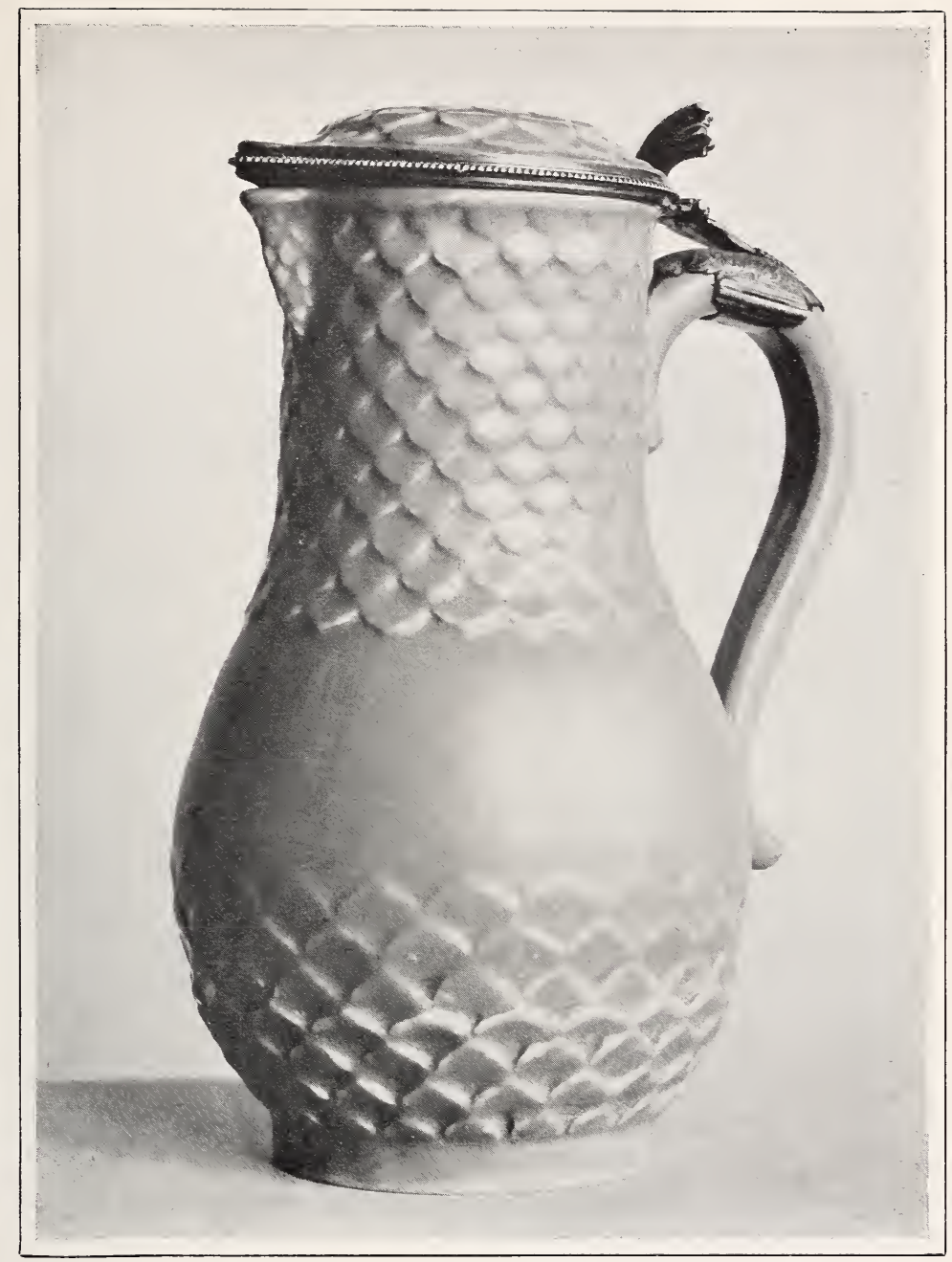

ST. CLOUd (Pâte tendre).

Fig. 5. -Jug Mounted With SILVer: THe GROUND HAS BEEN COATED WITH CELADON ON-GLAZE.

H. $7_{\frac{3}{4}}^{\frac{3}{4}}$ in. Dia. $4_{4}^{\frac{1}{4}}$ in

By kind Permission of J. H. Fitzhenry, Esq. Victoria and Albert Museum. 

plentiful, and include flower-pots of fairly large dimensions, cups, saucers, jugs, knife-handles, statuettes and grotesque figures, but the greater number of pieces are decorated with patterns in under-glaze blue, the ornament being skilfully arranged to enhance the modelling impressed on the body of the piece (see Fig. 4). A small number of pieces are known in which green, red, yellow, purple, and a blackish brown are used along with the blue. One very exceptional piece is at present shown in the Victoria and Albert Museum, namely, a small water jug (see Fig. 5) which has been covered with a fairly thin uniform coating of a pale celadon colour.

In an earlier volume of this series* Mr. William Burton has pointed out with great clearness the origin of the ornamental devices used by the first porcelain makers in Europe. They attempted to reproduce, as nearly as possible, Chinese and Japanese patterns, the better to compete with the imported porcelains of the East. Thus the white Chinese pieces, decorated with prunus flowers and branches in relief, which are so highly appreciated by all collectors on account of the beauty of their paste and the richness and brightness of their glaze, were especially imitated at St. Cloud, and this decoration of sprays and flowers in relief is often found on cups, saucers, and flowerpots. At other times, when the ornamental details were painted in colours they were still servile imitations of Oriental patterns. A good example of this will be found in the St. Cloud flower-pot (see Fig. 6) with polychrome decoration, which is preserved in the museum at Sèvres.

The forms of the cups and other vessels were also borrowed from the Chinese; nor can we wonder at it when we remember that all the beverages for which these cups were specially designed were themselves of recent importation. We may recall for instance that chocolate was first imported in 1651, and its use only became general in the reign of Louis $\mathrm{XV}$., that tea made its first appearance only in 1652, and that coffee from Mocha became common in 1670. In the train of these new luxuries of the East, cups and saucers, tea-pots and coffee-pots

* "History and Description of English Porcelain." Cassell \& Co., 1902. 
were needed to give the true Oriental flavour, and the potters of St. Cloud naturally turned to Oriental models for these new articles of luxury.*

No long period elapsed before European patterns made their appearance on these Oriental forms, and dainty scallop patterns (lambrequins) and fine ornamental designs eloquent of French taste were soon used to decorate the cups, sugar-basins, and coffee-pots. As a further refinement delicate modelling of the piece was often indulged in, and in this way we get the typical St. Cloud pieces modelled to resemble artichoke or lotus leaves, which are so highly prized by connoisseurs.

At the present time we have no knowledge of the gilded pieces or branched candlesticks mentioned by contemporary writers. It is nearly impossible to fix the date of any particular piece of St. Cloud porcelain. The same patterns and the same decorations were produced over so long a period, and the marks were so carelessly applied, that we have no sure guide for the exact chronology of any particular piece or series of pieces. The first mark used during the reign of Louis XIV. was a sun, impressed in the paste. Everyone knows that the sun was the royal emblem of Louis XIV., taken from the famous motto (nec pluribus impar), and it may be stated that all the pieces marked with the sun are in the style of the seventeenth century, and are noted for their quality and the elegance of their outlines. Subsequently the pieces were marked in blue with the letters "S. C." with a small cross above, and underneath, the letter "T." Sometimes numbers or detached letters are used in conjunction with this mark. It is easy to translate this mark into the words "St. Cloud-Trou," and to say that the other numbers or letters are the distinctive numbers of the pieces of different services, or the special marks of certain decorators. All the more so as the essential mark is occasionally defective, and many different blue initials are found, generally surrounded with little crosses. We may mention that the following initials are often

* It may be pointed out that a great number of the St. Cloud saucers have an inner rim (trembleuse) designed to prevent the slipping of the cup on the smooth part of the saucer. 


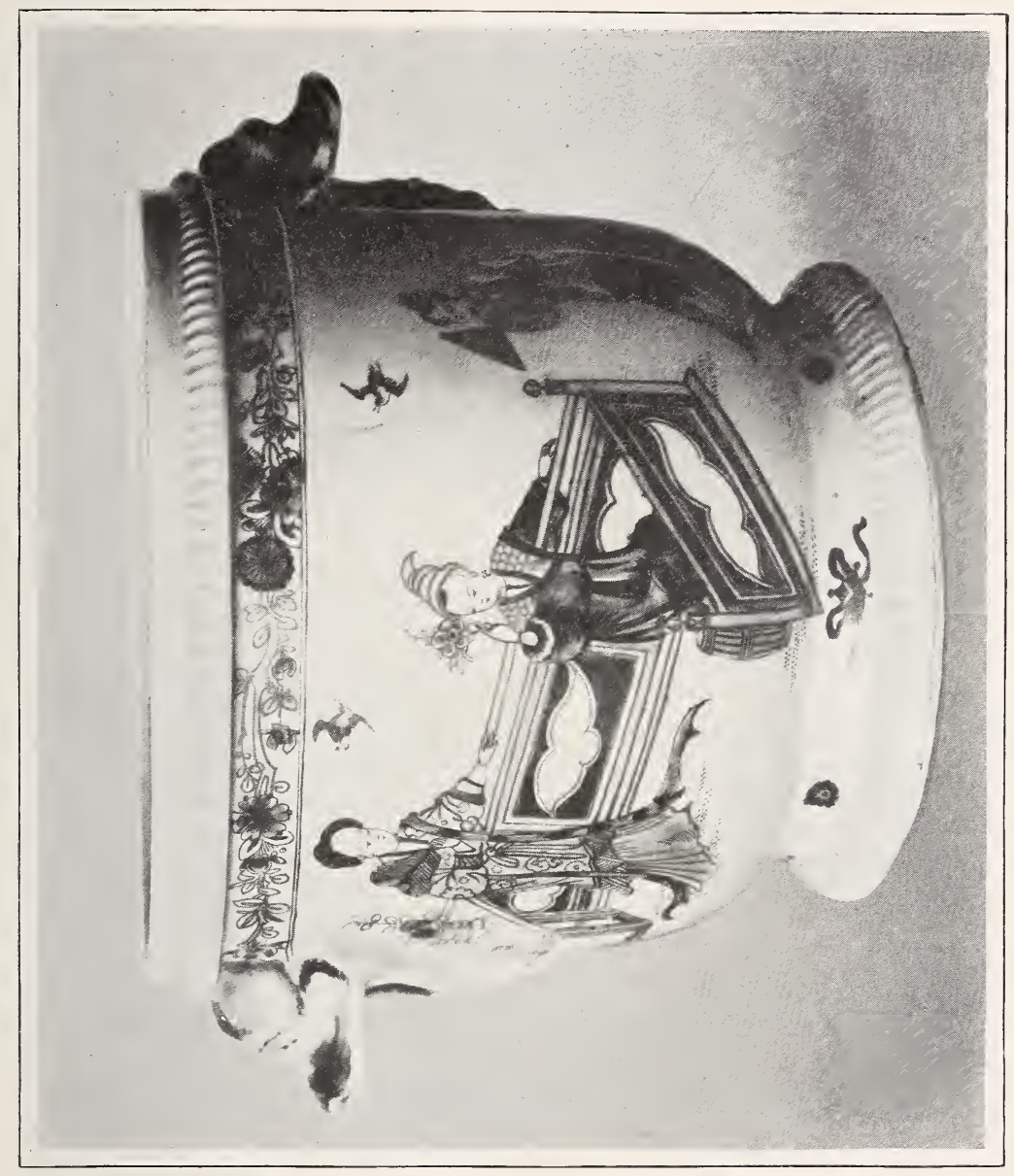

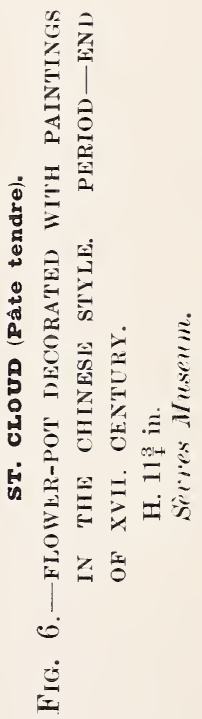



found written in this way:- "B. B.," "C. M.," "L. L.," "I. S." "P." "E.," "F.," "M.," either by themselves or accompanied by crosses or numerals.

It is possible that among the pieces bearing these irregular initials may be some which have proceeded from the two works we have mentioned in faubourg St. Honoré and faubourg St. Antoine, but on this question we have no certain knowledge.

LILLE.

It is known that the manufacture of porcelain was attempted at Lille about 1711 by a faïence-maker named Barthélemy Dorez and his nephew, Pierre Pélissier. It is recorded in a petition addressed to the Mayor and Council of Lille that Dorez exhibited to them samples of porcelain after the Chinese fashion with a view to display their beauty and their hardness, and that he sought the right of setting up an establishment in the town where he proposed to make porcelain as well as faïence that he might increase the reputation of the town of Lille. The Municipal Council accepted his petition, subsidised his works, and gave him the entire privilege of the manufacture and sale of porcelain in Lille. The terms of this grant were based on the declarations of Dorez, who stated that he was the only potter, besides Chicanneau of St. Cloud, who possessed the true secret of making porcelain similar to the samples that had been produced. Dorez adds in his petition that the master of the Rouen works, having believed he had penetrated the secret of porcelain manufacture, sent his ware to Paris to be sold as if it were made at St. Cloud, which gave a bad reputation to the ware of St. Cloud, owing to the inferiority of the Rouen productions, but the plot being discovered he was forced to cease the manufacture.

We have no means of knowing, now, if Dorez and Pélissier had acquired the secret of porcelain manufacture from St. Cloud or Rouen, or whether they had attained it by the happy result of blind experiment, though we incline to the belief that the former view is more probable. Be this as it may, it is certain 
that from the years 1711 to 1720 Dorez and his partner received a regular subsidy from the municipality of Lille. By 1720 they appear to have been firmly established, as a minute in the Journal of the Council of State declares that the brothers François and Barthélemy Dorez, the undertakers of the porcelain and faïence manufactory established in $\mathbf{1 7 0 8}$ at Lille, by the use of an earth that is found between Lille and Tournay, had offered to sell their manufactory to the King of France. The King contented himself with giving them several privileges relating to the customs and fiscal charges, but so as neither to infringe the monopoly of the French Indian Company, nor to irritate the Duc d'Orléans, the patron of the works at St. Cloud. $\mathrm{He}$ refused, however, to authorise the opening of a warehouse in Paris for the sale of the Lille porcelain. It was probably owing to this inability to reach the Paris market that the establishment at Lille did not endure. Its own market of Flanders, at that time spoilt by so many years of war, was insufficient to maintain a works of this class.

It will readily be seen, from the above-quoted statements made by Dorez in applying for help to the Municipal Council, that he aimed at rivalling the productions of St. Cloud, and it is not always easy, in the absence of marks, to distinguish clearly between the productions of the two factories.

The paste is analogous to that of St. Cloud, while the glaze exhibits exactly the same tendency to run in streaks, but it seems to us that the glaze was more liable to blister and that it oftener exhibited dry patches than the glaze of St. Cloud; the painting is not so skilfully done, and the painted ornament frequently has a dry aspect. It is obvious that the Lille potters confined themselves to imitations of the productions of St. Cloud.

With regard to marks, it may be stated that the mark $\mathrm{D}$ is sometimes found on pieces decorated with blue, and in addition the mark $A$ ), both of which are attributed to Lille. With regard to the mark $\mathrm{L}$, followed by a cross, it is uncertain whether this indicates Lille or is one of the before-mentioned marks associated with St. Cloud, as it is found on pieces, the 
decoration of which inclines one to attribute them to the latter factory. In any case it would be of the greatest assistance in clearing up this debatable point if we could find some pieces of soft-paste porcelain belonging to Lille that were marked and dated. It is not very satisfactory to think that most of the pieces attributed to Iille are so designated because they are thicker and more rustic-looking than the pieces attributed to St. Cloud. 


\section{CHAPTER IV.}

THE SOFT PORCELAIN OF CHANTILLY.

ONE of the most interesting features of the history of early manufacture of porcelain in Europe-as, indeed, of most of the successful efforts to manufacture artistic pottery of any kind - was the patronage and support afforded to the experimenters by the great nobles, princes or kings of different realms.

The Duc d'Orléans, as we have seen, became the patron of the works of St. Cloud, and it seems natural to find Louis-Henri Prince de Condé, known as Monsieur le Duc, the princely owner of the magnificent domain of Chantilly, providing funds for the experiments of Ciquaire Cirou, though it should be remarked that this patronage was only exercised after the death of the Duc d'Orléans. The works seems to have been founded about 1725, for in the letters-patent granted to Cirou in 1735 he states that during ten years it had been his constant study to produce, in Chantilly, porcelain like that of the Japanese; that he has surpassed Saxon porcelain; and that it is his intention to sell his products in France, as well as abroad in England, Holland, and Germany. In consequence of this statement the King granted him the privilege for twenty years of making, in Chantilly, fine porcelain of all kinds and colours in imitation of Japanese porcelain; reserving, however, the before-mentioned rights of the heirs of Chicanneau and of the Sieur de St. Etienne.

At this period the Prince de Condé was collecting with avidity specimens of early Japanese Imari ware, and particularly of those varieties which to-day are designated as "Kakiyemon," after the name of the famous potter who flourished at Imari in 
PLATE III.

CHANTILIY

(PÂTE TENDRE, ABOUT 1750).

Lobate Sugar-box and Stand,

Decorated in the Kakiyemon Style (DÉCOR Coréen).

Box-H, 4 in. L. $6 \frac{1}{8}$ in. TV. $5 \frac{1}{4}$ in.

Stand-L. $9 \frac{1}{2}$ in. W. $7 \frac{3}{8}$ in.

Victoria and Albert Museum. 


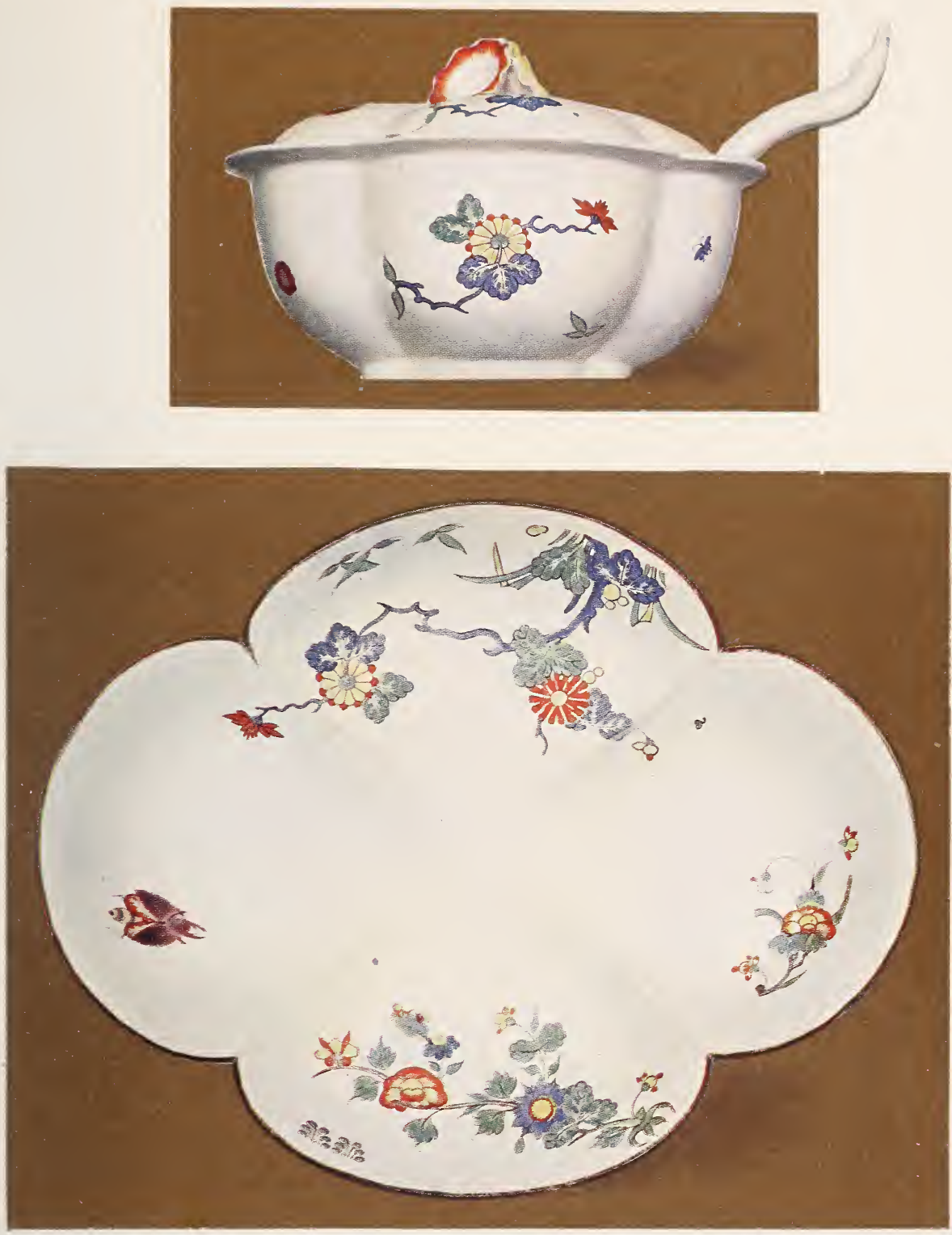

the province of Hizen in the second half of the seventeenth century.*

In these charming designs ornamental sprays, branches and flowers are thrown in an artistic way across the plates or other pieces of ware, interlacing, and sometimes enclosing quaint figures of the ibis, partridge or quail, or drawings of fabulous animals. These dainty Kakiyemon patterns painted in brilliant touches of red, yellow and blue, enhanced with a little gold, on a white porcelain of unequalled quality and finish, became the rage of the period all over Europe. Not only were they copied or adapted at Chantilly, and afterwards at Vincennes, in France, but they made their appearance almost simultaneously on the hard porcelain of Saxony as well as on the soft porcelains of Bow, Chelsea and Worcester.

At Chantilly, the influence exerted by this collection of Imari porcelain was not confined merely to the patterns or style of decoration. The attempt to rival the pure quality of the Imari glaze led to the production of an eminently characteristic porcelain. The body of the ware was a soft paste similar to that of St. Cloud, but the Chantilly glaze resembled the glaze of the failence-makers in being rendered milky-white and opaque by the addition of oxide of tin. It is this use of a stanniferous glaze which gives such a distinct aspect to the early Chantilly porcelain, which so closely approaches the quality of the Japanese hard porcelain that, in many cases, but for the constant rubbing or wearing of the soft Chantilly glaze it would be difficult to distinguish between the two wares.

The factory at Chantilly continued to produce porcelain until the revolution of 1789 , under the direction successively of Cirou, and Antheaume, and afterwards of Potter, de Baynal, and Lallement. Yet, under all these successive directors it never seems to have taken the first place as a creative centre, but was always content with beautiful reproductions of the successive styles introduced by the other leading factories in the course of the eighteenth century.

At first, as we have said, the Japanese style of Kakiyemon

* See also Burton's "History of English Porcelain," pp. 27-28. 
was imitated, and on the tin-white enamel the brilliant touches of blue, yellow, red and brown became all the more brilliant and vivid by contrast. For many years there must have been a very large output of dinner services, and tea and coffee sets, decorated in this style. The pieces were generally lobate in form, as in the characteristic sugar-bowl and tray preserved in the Victoria and Albert Museum, which we reproduce in Plate III. It should be pointed out that the body of the Chantilly porcelain must have been of a more solid and durable kind, and more stable in the fire than the body used at Rouen, St. Cloud or Lille, for we have not met with a plate or other large flat piece produced at any of these factories.

When the Saxon porcelain began to make its reputation in Europe we find at Chantilly, as at other French factories, timid imitations of the early Dresden styles.

Under Louis XV. the Chinese style had a great vogue in France, and Chantilly produced a series of grotesque figures and statuettes all in this Oriental manner. By this time Vincennes, and then Sèvres, had been established, while the factory at Mennecy was now reaching an important position. To meet this fresh competition a new transparent glaze was introduced at Chantilly in place of the earlier opaque glaze, and in other ways energetic attempts were made to move with the changing spirit of the times.

After the vogue of pieces decorated with little flowers in the Dresden manner came sketchy decorations in a transparent green etched with black, like that of the jug with silver mounts in the Victoria and Albert Museum (see Fig. 8).* Then decorations of flowers and birds after the style of Sèvres made their appearance, but among all these evolutions of pattern and decoration one feels that the forms of the pieces gradually become more refined and more distinctly French. Can there be anything more dainty or more ingenious than the two statuettes with panniers on their backs illustrated in Plate II.? Though one recognises in the forms of the statuettes, as well as in the powdering of flowers which adorns the draperies, the

* This style of decoration was also adopted at Chelsea and at Worcester.-ED. 


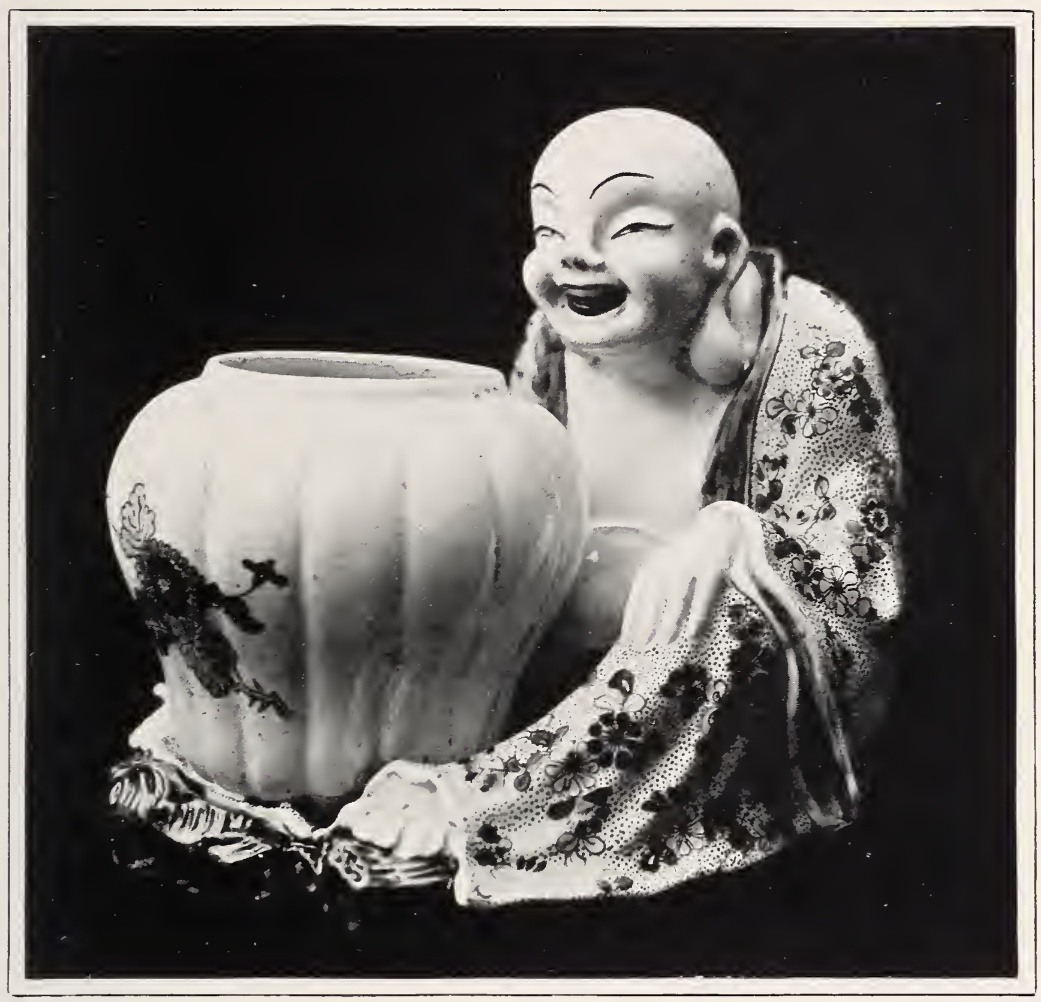

CHANTILLY (Pâte tendre).

Fig. 7.-Chinese figure and vase decorated IN BLUE, GREEN, AND RED.

H. $7 \frac{1}{2}$ in.

Cluny Museum. 



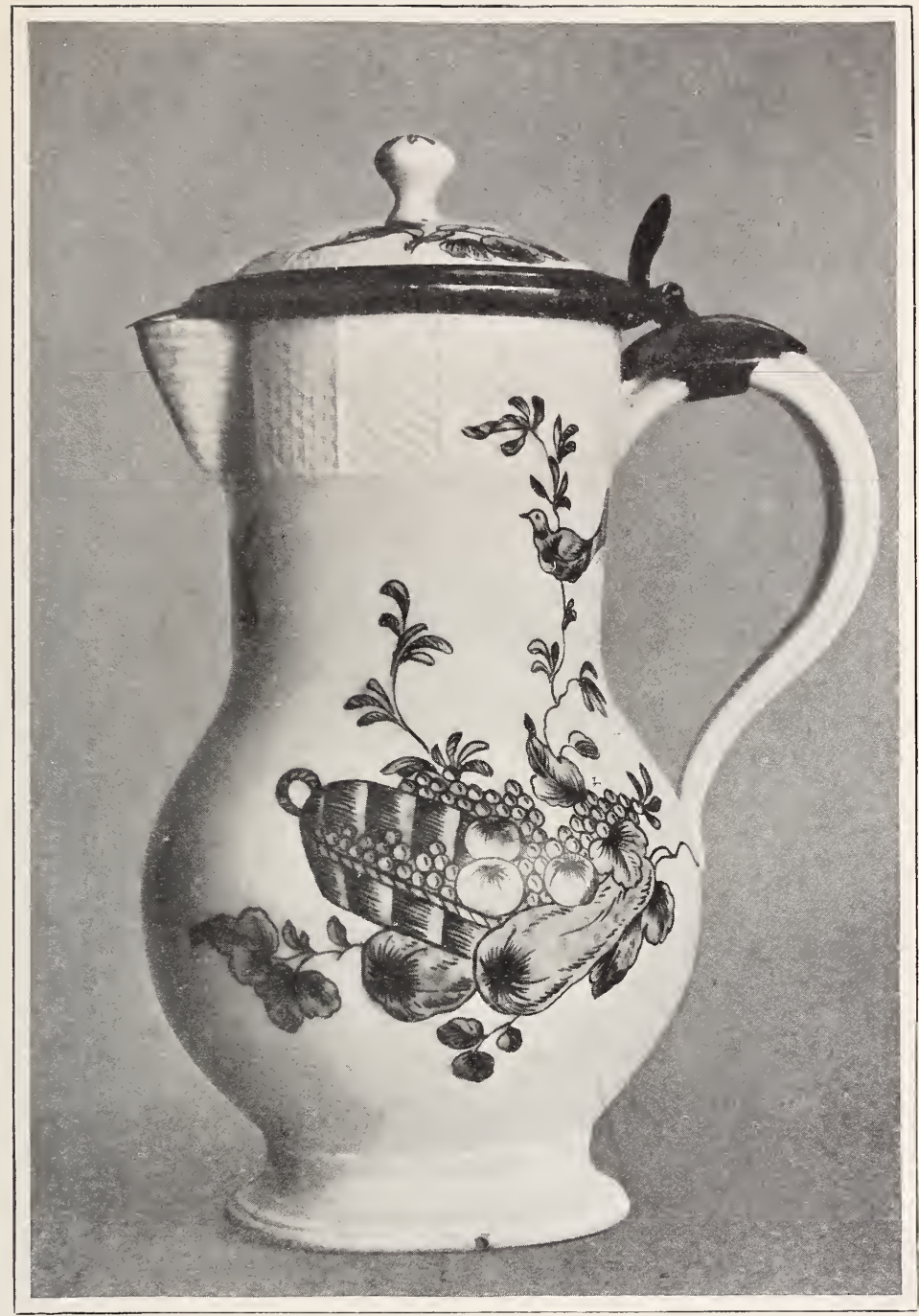

ChaNTILIY

(Pâte tendre, transparent glaze).

Fig. 8.-JUG DECORATED With PAINTING IN GREEN FNAMEL, ETCHED WITH BLACK.

H. $6 \frac{3}{8}$ in. Dia. $3 \frac{3}{8}$ in.

By kind Permission of J. H. Fitzhenry, Esq.

Victoria and Albert Museum. 

original Japanese influence, we cannot but feel how excellent is the bust of the "soubrette," and how typical of French taste at the middle of the eighteenth century.

At a subsequent period Chantilly imitated with great success the blue, green, rose-colour or yellow grounds of Sèvres, as well as the skilfully modelled bouquets of flowers which were used in the bronze branched-candlesticks to form such characteristic decoration for the rooms of the period. But for the mark, it would often be impossible to distinguish Chantilly pieces of this class from those produced at Sèvres.

As all the princes and great lords of the period appear to have been customers at the factory its productions are nowadays found in many collections. The Condé museum at Chantilly is especially rich in early pieces with the opaque glaze and Kakiyemon designs (à décors Coréens).

The general Chantilly mark was the hunting horn, carefully drawn, generally in on-glaze red. Towards the end of the eighteenth century we find the same mark, but in blue, and with the addition of letters and figures to denote the different pieces. It is not uncommon to find that late pieces of Chantilly ware, of the transparent glaze, have had the mark removed by ingenious forgers and replaced by that of Sèvres.

It is interesting to mention finally that the brothers Dubois, who founded the factory at Vincennes, were employed at Chantilly about 1735 . 


\section{CHAPTER V.}

THE SOFT PORCELAIN OF MENNECY-VILLEROY.

THIs factory owed its inception to the patronage of another of the great nobles of the French court, Louis-François de Neufville de Villeroy. He owned, in his domain of Villeroy, a little faïence factory, from which a curious specimen is preserved in the museum at Sèvres. This is a pint pot decorated in the Rouen style with the arms of this prince, and the inscription "De Ville Roy," and also marked underneath "D. V."

It appears to have been here that Barbin created and developed, about the year 1735, a manufacture of soft porcelain without having obtained the necessary authorisation by letterspatent, so that we may realise how powerful a personage his protector must have been to shield him from the troubles that at this epoch attended those who sought to evade a monopoly or a privilege.

In 1748 Barbin applied for permission to establish a kiln in Paris, but this privilege was refused because His Majesty the King had granted to Charles Adam the privilege of imitating Saxon porcelain (it was no longer merely a question of Japanese or Chinese porcelain), a privilege which Adam could only develop to the full while he was free from competition, and while his workmen might not even be employed outside the royal establishment at Vincennes. It was also stipulated that Barbin must not employ any workmen who might have worked at Vincennes, neither must he copy nor imitate the productions of that royal manufactory. This same edict speaks of those who, "without possessing any legal privilege, and under the authority 

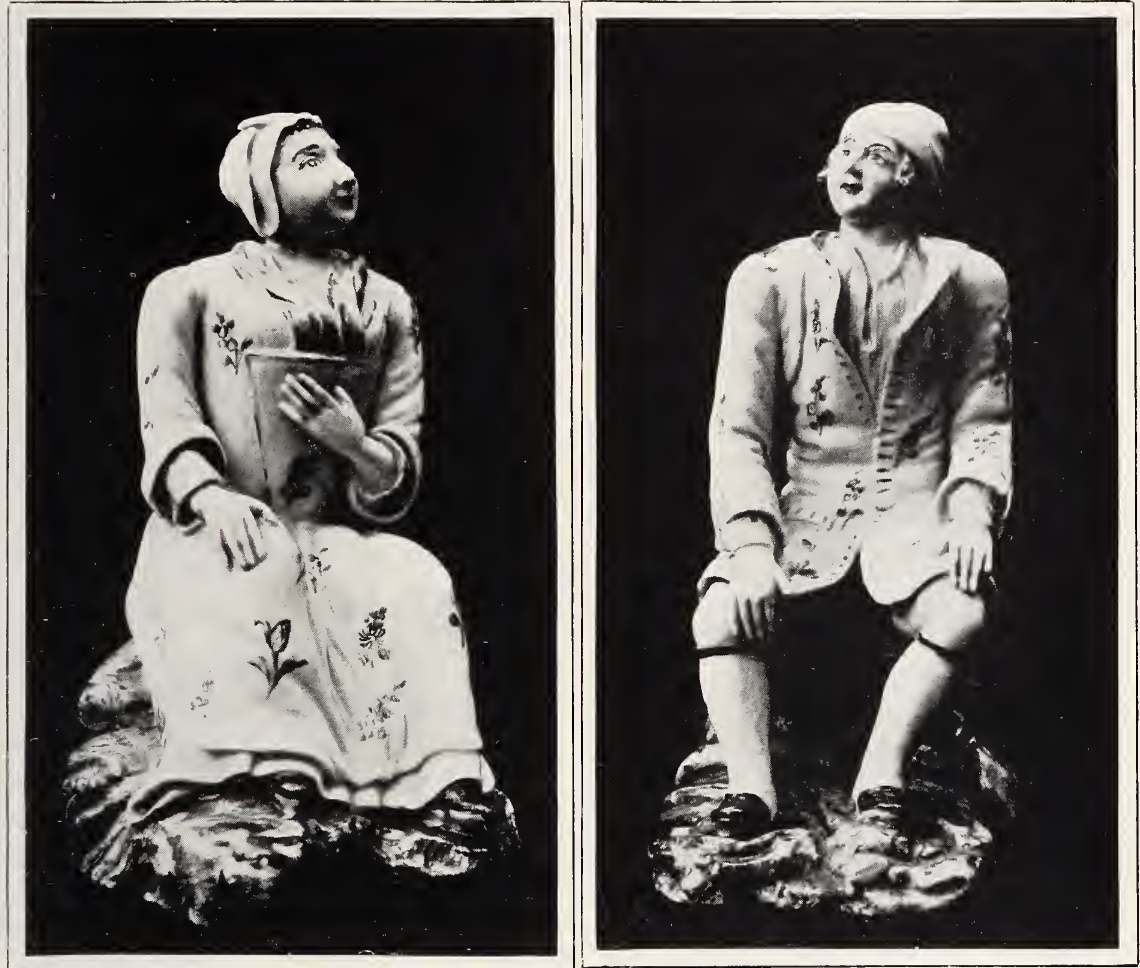

\section{MENNECY-VILLEROY}

Figs. $9 \&$ 10.-RUstic Figures Decorated With

FLORAL SPRAYS PAINTED IN COLOURS.

H. 9 in.

Cluny Museum. 

of some especial permission, worked at the manufacture of porcelain," which is supposed to be a hint at the establishment of Mennecy-Villeroy.

Barbin's first experiments appear to have been in imitation of the ware of St. Cloud. There is preserved in the museum at Limoges a pomatum pot of a yellowish paste, spotted and streaked, badly fire-cracked, and with a very uneven glaze, which manifests all the defects of a new manufacture. The piece is decorated with little bouquets of flowers, painted in the style of enamelled faïence, but revealing undoubted Saxon influence. If the mark " D. V." was not so very characteristic of Mennecy one might have considered it a piece of early St. Cloud manufacture that had been decorated at some subsequent period.

As we have already stated, the first attempts at Mennecy were after the manner of the porcelain of St. Cloud, which is proved by the fact that M. Aymé Darblay, the author of an important work on Villeroy, has found, during excavations in a part of his property where the manufactory was situated, knifehandles decorated with under-glaze blue in patterns imitating those of the well-known lambrequins of Rouen. Other pieces are known with designs in enamel colours, blue, green, red, and yellow; of such brightness that they might have been attributed to St. Cloud had the pieces not been marked. If at a later time pieces were produced with opaque glaze which imitated the productions of Chantilly, their perfection of manufacture is not such as would cause them to be confounded with the pieces from the more famous works, but all this evidence shows us the first efforts of this manufactory before a decided Mennecy style had been evolved.

François Barbin was succeeded by his son Jean-Baptiste, who was soon taken from the direction of Mennecy by an untimely death. The works passed into the hands of MM. Jacques and Jullien, one a painter and the other a sculptor, in 1766, and remained in their possession until 1773 or 1774, when the manufacture at Mennecy ceased. The date of this purchase is fixed by a placard, found among the 
advertisements, placards and various notices of March 24, 1766, which indicates that the manufactory of Mennecy-Villeroy was to be sold on the 31st March with all its beautiful porcelains, that is to say, "Cups, saucers, antique vases, groups, pedestals, mustard-pots, gravy-boats, dishes, covered dishes, cruet-stands, powder-boxes, sugar-boxes, sugar-bowls for the table, and fruitbaskets of various forms." Jacques and Jullien were at this time tenants of the works at Sceaux, so that it would seem as if they came to Mennecy in 1766.

The principal and most distinctive period of the Mennecy factory is that covering the attempts to imitate the productions of Vincennes and Sèvres; yet surely it is not possible for an instructed amateur to make a mistake between the productions of these factories. The pieces from the two royal works have a fine white paste that cannot be compared with the dark ivory colour of that of Mennecy, even if the painters connected with the Duke of Villeroy's works knew how to imitate the Saxon decorations as well as those of Sèvres, while their flowers and birds, although a little heavy, often rival in their finish and perfection the paintings executed at the royal manufactories. Sometimes, too, the most famous of the Sèvres processes were copied, such as the grounds of bleu de roi enlivened with the decoration d'œil de perdrix, with gilding and with flowers. This imitation is sometimes carried so far that we find by the side of the mark "D. V." engraved in the paste, the painted mark of two crossed "L's"; the mark of Sèvres.

The forms of the Mennecy pieces are extremely varied. During the period of the Chinese style, flower-pots seem to have formed the most important branch of manufacture. Afterwards we find pot-pourri jars, derived from European models but united with ibises or Japanese exotic birds. Still later we find a great number of purely European shapes: cups, saucers, milkor coffee-pots, tea-pots, water-jugs and basins, which are adaptations, but not servile copies, of the models of other factories. Among the modelled pieces especial attention may be drawn to the groups of statuettes and decorative wall-brackets. The reproductions of two Mennecy statuettes, representing a 


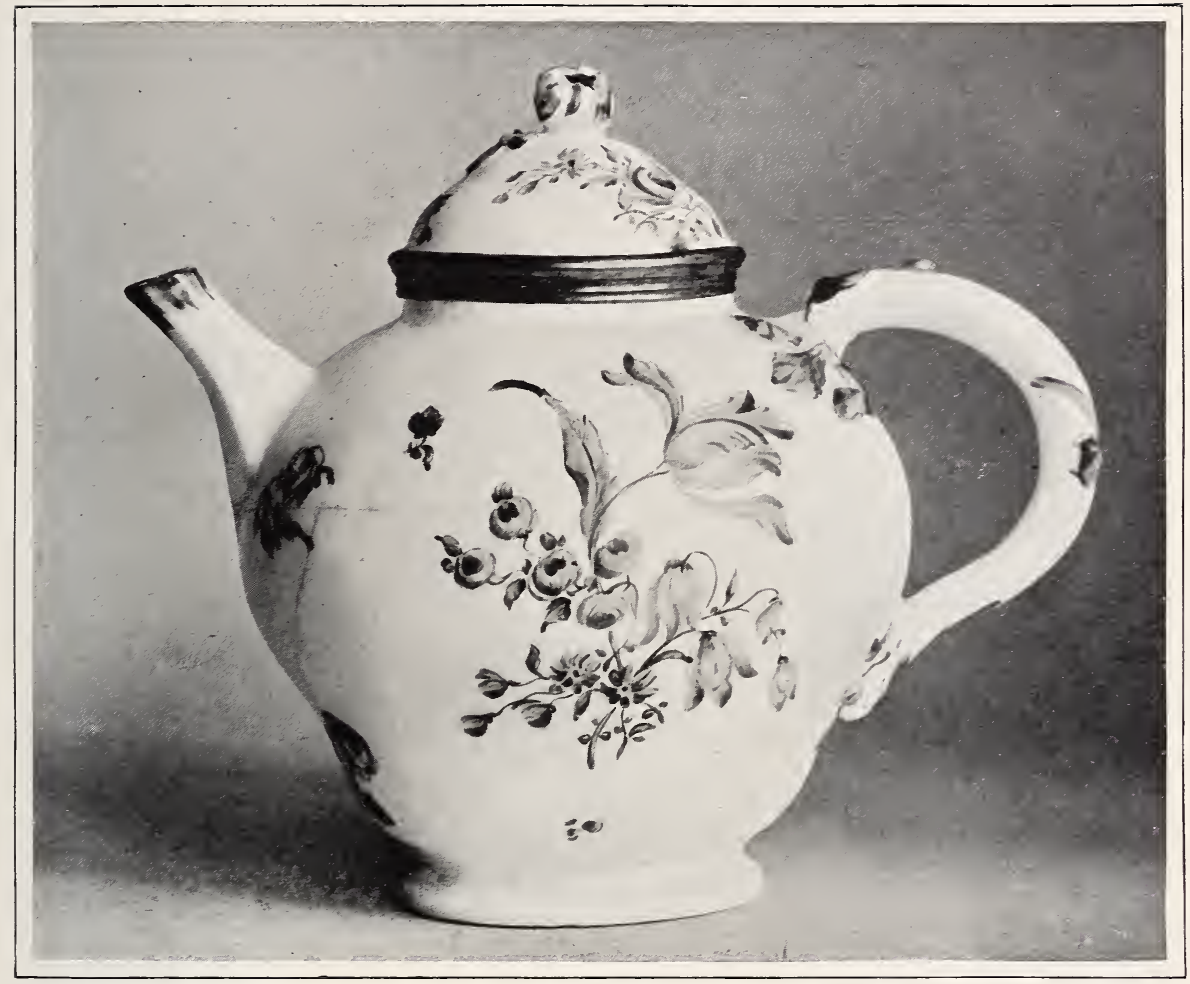

MENNECY-VILLEROY

(Pâte tendre).

Fig. 11. - TEAPOT WiTh MODELLED HANDLE AND KNOB DECORATED WITH FLOWERS PAINTED IN COLOURS.

H. $5 \frac{1}{2}$ in. W. $6 \frac{5}{8}$ in.

Victoria and Albert Museum. 


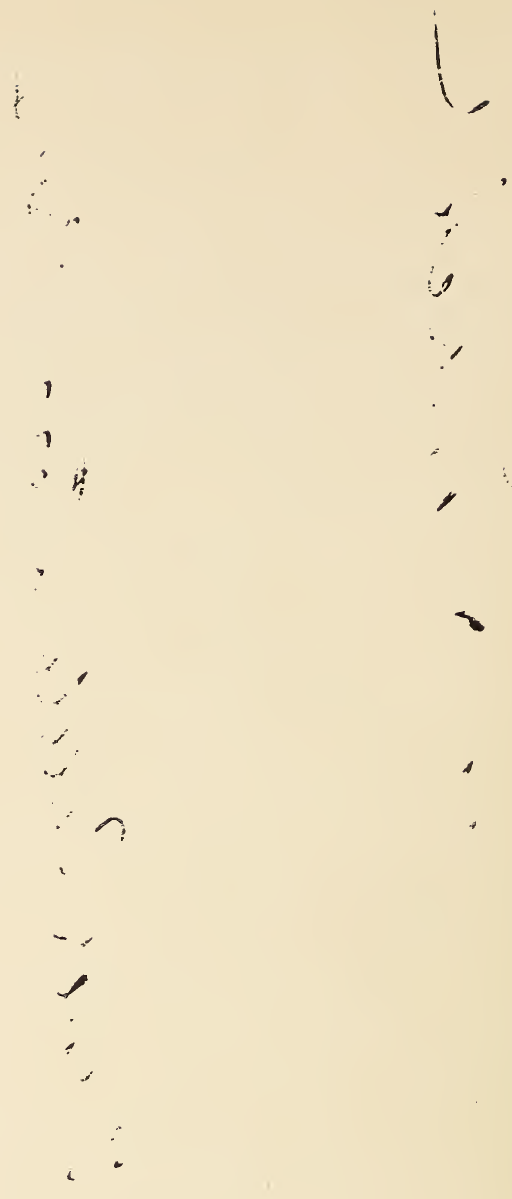


countryman and a countrywoman, which are preserved in the Cluny Museum, will give as good an idea as it is possible to obtain by illustration of the characteristic appearance of these Mennecy pieces (see Figs. 9 and 10). The collection that M. Darblay has brought together in the Château de Villeroy contains several hundred examples, among which there is a statuette representing Louis XV. standing.

Polychromatic decoration was largely used at Mennecy, and a rose colour of a decidedly purple hue may almost be said to be characteristic of the ware. Flowers were largely used as painted ornament, and of these yellow, blue, rose, and lilac ones predominate. It should be mentioned that as it was impossible for this factory, in consequence of the jealously held privileges of the royal manufactories, to gild its pieces openly, the top and bottom fillets and ornamental mouldings of the pieces are often outlined with a rose, blue, or yellow line. The lids of tea- and coffee-pots frequently end in flowers, which are finely modelled and carefully picked out in colours (see Fig. 11). Besides these gaily coloured flowers and birds one also finds, on certain snuffboxes, miniature battle scenes, containing as many as twenty horsemen (museum in the Château de Villeroy), and some cups and saucers are known with painted figures after the style of Watteau and Lancret.

Another mark of the artistic importance of Mennecy is found in the fact that they ventured to produce pieces in "biscuit," a material that is so difficult to produce successfully because each little fault is obvious even to the uninstructed observer, and there are no means of disguising it.

It should be said that at Mennecy vertical pieces were apparently produced in preference to flat pieces such as plates and dishes. As a consequence Mennecy plates are extremely rare, and command a high price when they happen to come into the market.

The earlier pieces of this factory are marked " D. V." painted in enamel colour. Afterwards the mark was scratched in the unfired paste, and this is very characteristic of Mennecy. The distinctive amber colour of this particular porcelain has 
rendered its imitation difficult, but during the last few years we have come across several forgeries of this ware, and although the well-known letters " D. V." had been cut into hard porcelain paste with the lapidary's wheel, there were still found amateurs ignorant enough to buy such gross counterfeits. 


\section{CHAPTER VI.}

\section{THE ESTABLISHMENT OF A MANUFACTORY AT VINCENNES.}

Is consequence of the discovery of hard-paste porcelain, strictly analogous to the true Oriental product, by John Frederick Böttger, working at Dresden in 1711, a new and mysterious industry was founded, and the utmost pains were taken by those interested in it to keep its processes secret. At first only brownish stoneware, not glazed, but polished by a lapidary's wheel, was manufactured; then this same material was decorated with patterns in white enamel; and finally there issued from the works-prison of Meissen a true white kaolin porcelain that could be decorated with red, blue or green colours. Only towards 1720 did under-glaze blue, in imitation of the Chinese, make its appearance, and then successively all the other colours and gilding.

The Saxon princes had, with very great reason, encouraged this rising industry, and spared no expense or pains in its development. They aimed not only at the production of table ware or tea-services after Oriental models, for garnitures, intended for the decoration of a Japanese palace built by Augustus III. on the banks of the Elbe, were also attempted, and we find statues, mantel-pieces, vases, window- and doorcasings, and clock cases specially designed for this purpose by Kändler, a sculptor of merit.

This unexpected success produced a great effect in France, especially as at that time the two courts were intimately connected by the marriage of a Saxon princess, the Dauphiness Marie-Josèphe, with the Dauphin Louis, son of Louis XV. If we compare this new Saxon porcelain with the porcelain of St. 
Cloud, of Chantilly, or Mennecy, we are at once struck with the difference of the material. The Saxon porcelain is harder, it is not so easily scratched, it is less fragile, while it is also whiter and of superior lustre. It is no wonder, therefore, that we should find the great financiers of the period willing to subsidise inventors who professed their ability to bring the French porcelain to such perfection that it might rival that of Saxony.

There were at this time two workmen at Chantilly, the brothers Dubois, one a sculptor and the other a painter, who had surreptitiously obtained a knowledge of the methods used there for making the Chantilly porcelain, with its glazes and colours. Over head and ears in debt, and guilty of gross misconduct, they were turned away from Chantilly and retired to Vincennes, where, along with Gérin, another fugitive from Chantilly, they attempted to manufacture porcelain. Gérin built the ovens, and a special kiln for firing the painting and the gilding, while the brothers Dubois charged themselves with the modelling and decoration of the pieces. Some success attended their efforts, and about 1740 they began, with much mystery and secrecy, to sell their porcelain in Paris. It is said that the Marquis du Châtelet who had bought some of their pieces, showed them to Orry de Fulvy, brother of the superintendent of royal buildings. He was much astonished at the results obtained, and asked to be allowed to visit the works, or, better still, the laboratory where the Dubois carried on their secret operations. Becoming interested in their experiments, he obtained, through his brother's influence, the King's permission to use some of the buildings connected with the château at Vincennes, which had been unoccupied for a long time, besides obtaining for them several monetary subsidies. About this time one Gravant, who is also supposed to have acquired the secret of porcelain making, at some other factory, associated himself with the enterprise and a sum of 10,000 livres was advanced to enable them to extend their business.

A manuscript of Millot's, preserved in the library of the Sèvres Museum, and giving an account of the establishment of the works at Vincennes, tells us that their production was most 
unreliable; at least five-sixths of the pieces came out of the oven imperfect, even when the whole lot was not spoiled, so that in a very short time the partners, driven to bankruptcy, quitted Vincennes surreptitiously, leaving behind them all the materials and such pieces as there were, for the satisfaction of their creditors. This was naturally a great blow to Orry de Fulvy, as the debts exceeded 50,000 livres, and the assets were not very realisable. This enormous loss was said to have been caused entirely by the bad management and misconduct of the brothers Dubois, who, according to the authors of that time, were both drunken and reckless. They were, however, the principal sufferers from their own misconduct, for Gravant, taking advantage of their negligence, had copied all their notes relating to the composition of the paste and the method of firing, and he now persuaded Orry de Fulvy to carry on the experiments for some time longer. Gravant also succeeded in obtaining other porcelain workers from Chantilly, and he bought from a man named Caillat the secret of making certain colours. In 1745, after several years of hard work, success crowned these efforts, and a beautiful white porcelain was successfully manufactured. By the aid of his brother, Orry de Fulvy was able to form a company of promoters from among the financiers of the day, nearly all of whom were connected with the "fermes" or farming of taxes. M. Gravant agreed with this company to procure and supply the paste for forming the porcelain pieces, as well as the glazing materials, and to give a written copy of the secret of these two compositions to M. de Fulvy, who charged himself with performing the experiments. It was arranged that when these experiments had proved the accuracy of the information, M. de Fulvy should deposit with a notary in Paris a document containing the receipts as well as an undertaking that if the manufactory was maintained for ten years from the 1st January, 1746, Gravant should then be paid the sum of 24,000 livres, while from 1748 he should be paid an annual sum of 1,200 livres by way of salary.

The company, by the aid of M. de Fulvy's brother, further obtained, on the 24th July, 1745, a privilege from King 
Louis XV., signed in the camp at Boost. It is curious that this privilege was granted in the name of Charles Adam; and that it was for the establishment of the manufacture of porcelain, after the style of Saxon porcelain, at the château of Vincennes; the privilege being granted for thirty years. Large premises at Vincennes and at Bel-Air, a little place in the neighbourhood, were granted for the use of the company at the same time as this privilege, showing, for the first time, the direct interest taken by royalty itself in the development of porcelain manufacture in France.

The organisation of the works became more perfect by the introduction of new elements. The fact that the company was supported by the financiers of the day encouraged men of position to accept employment at Vincennes. A clerk from the office of taxes, named Boileau, a clever administrator, became managing-clerk. The celebrated chemist and academician Hellot, author of some remarkable works on metallurgy, conducted the chemical operations; the modelling was superintended by Duplessis, a goldsmith and sculptor; while an artist named Bachelier, and an enameller to the King, named Mathieu, directed the painting and decorating. A warehouse was also established, of which Blanchard became the keeper, and the secret of applying gold to porcelain was bought from the Benedictine friar, Hippolyte, of the Abbey of St. Martin des Champs, for a relatively large sum.

It is not surprising to find that after all this expenditure on the creation of new models, on experiments and researches in every direction, the financial results were at first unsatisfactory, and it was found necessary in 1746 to increase the share capital, while a further sum was raised early in 1747 . In spite of all these efforts and all this expenditure it was not until 1748 that success crowned the work. The Duc de Luynes who has left such interesting memoirs of the period relates that on April 13th, 1748:-

"M. de Fulvy, who continues to be the director of the porcelain manufactory at Vincennes, had a porcelain vase brought to the Queen, which he presented to her on behalf 
of the company. Three small white figures, together with a porcelain vase, were mounted on a gilt-bronze pedestal. The vase contains a bouquet of flowers also made in porcelain. M. de Fulvy told me that there were 480 flowers in the bouquet. The vase with its pedestal and the flowers stood about $3 \mathrm{ft}$. high. The bronze mounting alone cost 100 louis (£94), and the porcelain just as much ; it is a perfect work of its kind-as much for the whiteness as for the execution of the small figures and the flowers. This manufactory is now superior to that of Saxony for the making of flowers."*

The sale register of this date, which happens to be preserved at Sèvres, shows that the cost was 2,600 livres, and not 2,000 as the Duc de Luynes says; but apart from this detail it is certain that, as he says, the success of the present was great; so great, that the young Dauphiness, Marie-Josèphe, a finished diplomatist, ordered a similar vase as a present for her father, Frederick Augustus, Elector of Saxony, to show him that the Vincennes porcelain was quite equal to that of Dresden. The first intention was to have the present conveyed on a hand barrow by two men, who were to have been on the way thirty days, and were to have been paid at the rate of 100 sols each per day. Finally, however, it was decided to take the vase to pieces, pack it carefully and send a workman from Vincennes to remount it at the Saxon Court. This piece is now preserved in the Johanneum at Dresden, and is reproduced in Fig. 12.

Notwithstanding this success, and the growing favour which the porcelain met with at court, the financial position of the company still remained unsatisfactory. On December 11th, 1749 , the company borrowed 12,000 livres, while in March, 1750 , it appears that they were unable to pay a bill of 6,000 livres and had to borrow again. To avoid these constant borrowings, and to provide fresh capital, it was decided to increase the number of shares from twenty-one to thirty-the nine new shares thus created bringing in the sum of 126,000 livres. When we add to this the fact that the King had given a subsidy of 40,000 livres in 1747, and further sums of 30,000

* "Mémoires du Duc de Luynes," édition Firmin Didot II., 12. 
livres in 1748 and 1749 , we realise what an expenditure of money the enterprise needed.

At this time (1750), in addition to the chiefs of departments already named, there were three sculptor-modellers employed to produce the models under the direction of Duplessis; two moulders to make the working-moulds; five turners (throwers), two moulders (potters), and twenty-seven repairers (workmen who made and applied flowers, handles and reliefs). Two chemists, Bailly and Jouenne, assisted Hellot; seventeen male and female painters were employed under Bachelier; while the staff was completed by two women burnishers. One constant pre-occupation of the company seems to have been how to retain so many men and prevent them from carrying off to other works the processes employed at Vincennes; and an edict was obtained in 1747 forbidding, under severe penalties, any of the workmen of Charles Adam from seeking employment elservhere, or divulging the secrets of the manufacture.

A final effort was made to establish the finances of the company on a satisfactory basis in December, 1750 , and the capital was increased to 550,000 livres, divided into 220 shares of 2,500 livres each. It is evident that those who had financed the undertaking from the beginning still retained their faith, or their pride, in the work, and this is perhaps not so surprising in view of the interest taken in the venture by the King himself, and the considerable subsidies, as well as the privileges, he had from time to time granted to it. Further light is thrown on the condition of affairs in the memoirs of the Duc de Luynes already quoted from. $\mathrm{He}$ mentions an interview that he had with M. de Fulvy, in 1749, who told him :-

"There are actually nearly one hundred workmen who work at Vincennes, some of whom are paid so much a day, while others are paid by the piece. One of the great difficulties is the earth for the moulds; this earth must not be mixed with any metal for it stains the porcelain. Some of the right kind is so dry (short) that at every firing the moulds break and cannot be used twice.* M. de Fulvy hopes that his manufacture, being

* It is evident that there has been a blunder here. See p. 47.-ED. 


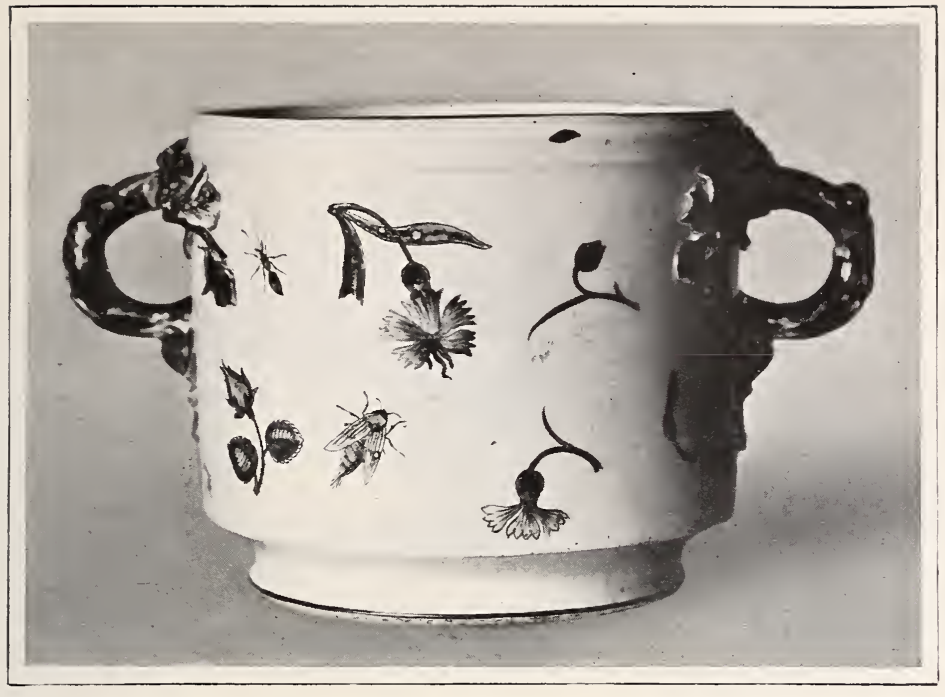

VINCENNES (Pâte tendre),

Fig. 13.-FLOWER-POT WITH PAINTED SPRAYS, ETC. PERIOD 1740-45.

H. $6 \frac{7}{8}$ in.

Sèrres Museum.

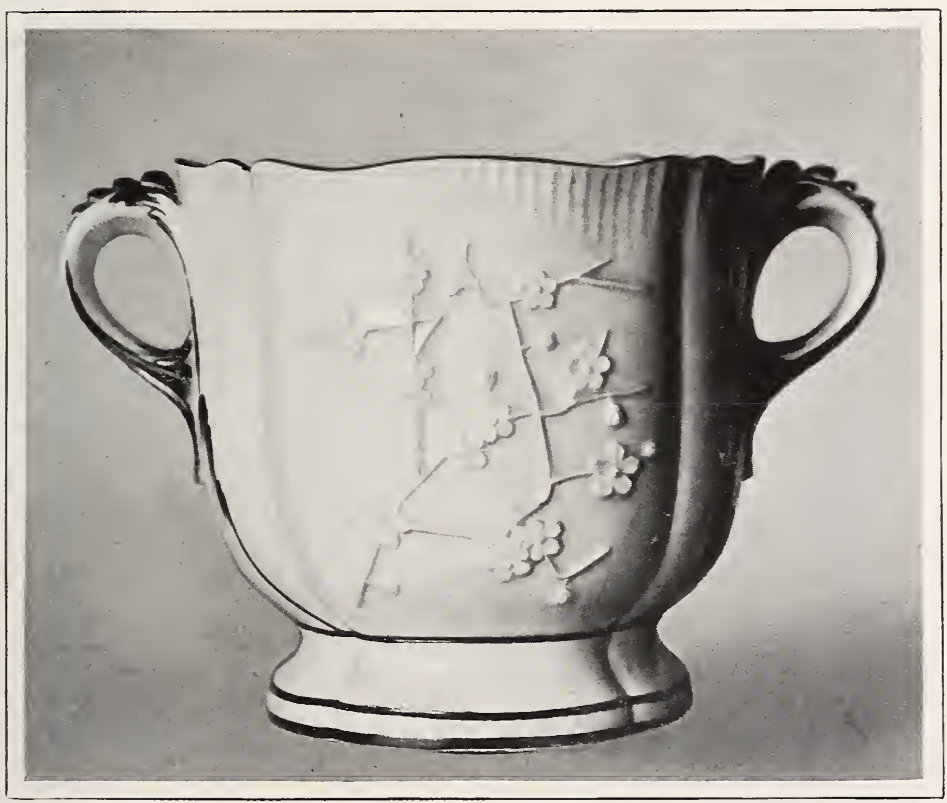

VINCENNES (Pâte tendre).

Fig. 14.-Flower- POT DECORATED With SPRAYS IN RELILF. PERIOD 1755.

H. $9 \underline{1}$ in.

Sèrres Museum. 

well supported, will sell from 700,000 to 800,000 livres' worth of produce per year; about 300,000 livres' worth in France and the rest in foreign countries. They have already sent pieces there with great success, and many foreigners impatiently wish to be able to buy more. M. de Fulvy, however, does not wish to sell them publicly before the month of August next, so that the 'undertakers' may have time to fill their warehouses. The English want only white porcelain, but as they might use this to paint upon, they are sold just as dear as the painted ones."

Further on in the same account he adds :-

"There are several other manufactories in France, as at Chantilly, St. Cloud, Mennecy and Sceaux. The 'undertakers' of these come, or send their people, to see the manufactory at Vincennes, to learn the processes so that they may imitate them, or to try and tempt some of the good workmen away by promising them higher pay. To put an end to these two inconveniences, M. de Fulvy has obtained an order that none is allowed to see the workmen at work in the factory, by reason that these frequent visits had at least the inconvenience of delaying the workmen in their work."

We may take it that these were the views and hopes of M. de Fulvy about 1749-50, and although he was altogether too sanguine as to the probable amount of the sales, we cannot be so much surprised when we remember the praise bestowed on his productions by the court, and the fact of the interest shown by the King himself in the undertaking. But all these ambitious views were cut short by the unexpected death of the two brothers De Fulvy, the minister dying in 1750, and the manager of Vincennes in 1751, within a few months of each other. By the terms of their articles of association the company had to pay out to the heirs the sums invested by the De Fulvys-and this was clearly impossible at a moment when the financial situation of the company was barely established, and there was practically no available cash reserve. It was this unexpected combination of circumstances which ended in making Vincennes a royal manufactory, but as we propose to treat of that important event and its consequences in the next chapter we must pause in our 
narrative to consider what had been done at Vincennes in these early years, and the processes by which it had been done.

Fortunately there is preserved, in the national archives of France, a manuscript record which enables us to describe the materials and processes employed at Vincennes. For the paste a mixture was prepared of Fontainebleau sand, native saltpetre, sea salt, soda of Alicante, Roman alum, and parings of alabaster. This mixture, carefully pounded and sifted, was spread on a bed of sand forming the "sole" of a frit kiln, in a layer about a foot thick. It was then heated by a progressive fire for about fifty hours until it became red hot, but not above a lemon-coloured heat, and that was the critical part of this operation. The frit thus obtained should be snow-white, and not too much vitrified; if there were pieces of it that were reddish in colour, that was a sign of insufficient fire, and the reddish portions must be picked out and re-heated with the next batch. The proper frit was carefully selected and pounded, and of this frit 900 parts were taken and put into a mill with 300 parts of marl from Argenteuil, the mixture being ground with water for about three weeks. The fluid paste was then allowed to dry in troughs, being afterwards crushed and sifted, and made into bolls with water, in which condition it was known as "new" paste. This new paste was mixed, in the proportion of one third, with the scraps and broken pieces of paste that were returned from the throwers, the handlers, the moulders, \&c., and in order to make the mass plastic it was mixed with a solution of green soap in boiling water. This means was also employed for making the "new" paste plastic when it was used for shaping large pieces in moulds.

The glaze was prepared by melting together Fontainebleau sand, litharge, soda, black flints of Bougival, and potash. These materials were mixed together and sifted, and then melted in crucibles heated in the floor of the porcelain furnace. At the conclusion of the firing the crucibles were broken and the clear, glassy portions alone selected. This was pounded, apparently dry, and mixed with water, a little white-wine vinegar being added to increase its covering power when sprinkled on the 


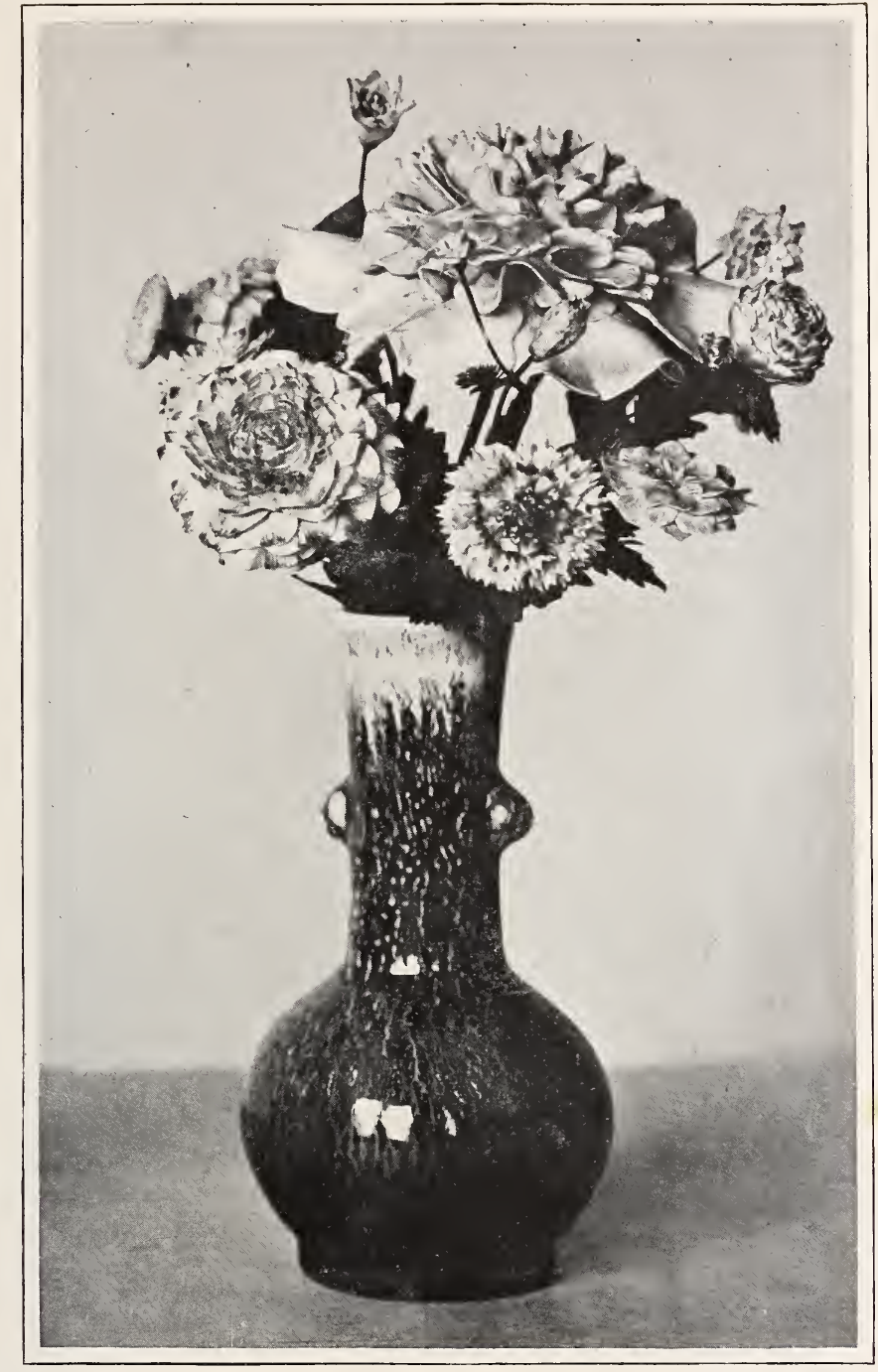

VINCENNES (Pâte tendre).

Fig. 15.-Bouquet of PAINTED Flow PERIOD 1755-56.

(The vase is of modern porcelain.) Sèvres Museum. 


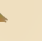


biscuit ware. It would seem from such a clear account that the manufacture of this porcelain ought to be possible to-day, but not only have we tried it ourselves, but it has been tried by many others, yet without success. In those far-off days chemical terms had no precise meaning, and the minerals used under the names of "native saltpetre" and "Roman alum" may hare been quite different from what we know by those names to-day; at all events, no modern experiments have ever succeeded in reproducing the soft-paste of Vincennes.

One of the greatest difficulties, after having prepared the paste and fashioned the piece, was to support it during the firing. In an earlier volume of this series, "The History of English Porcelain," will be found an illustration (Fig. 24) of the elaborate system of "propping" used for this purpose. When the Duc de Luynes speaks of the moulds that had to be destroyed after once using, he is probably referring to these props, which could of course only be used once, and which were, therefore, a great expense. (See p. 44.)

We may now describe the characteristics of the ware produced in this elaborate manner. From 1740 to 1745 , while the brothers Dubois remained at the head of affairs, the ware was of thick, slightly greyish paste, with a very beautiful clear glaze. The little flower-pot carefully preserved in the Sèvres Museum, which we illustrate in Fig. 13, is quite representative of this period. Every fault in the body or glaze is hidden by a painted flower or a fiy, disposed on the piece with seeming artlessness. This device was copied from the faïence-makers, and in our opinion the Dresden porcelain makers invented the style of decoration by "scattered flowers" only to hide the spots and blemishes in their pieces. It is interesting to notice that in this early piece the handles are covered with brown colour and there is no gilding.

A piece of the period 1755 (see Fig. 14), also a flower-pot, shows the progress made in ten years. The prunus blossoms in relief, well designed, with a few touches of purple colour, show to advantage a paste of good quality, and an excellent glaze, quite equal to that of the rival manufactories. 
We may best sum up the qualtities of early Vincennes in the whiteness of its paste and the simplicity of its decoration. The flowers are very simply painted, without dark outlines or pronounced shading; the birds, vigorous but slender, remind one of the interest excited by the rare birds brought from foreign lands.*

We have already given the contemporary account of the vase presented to the Queen in 1748, and of a similar one which was sent to the Saxon court. These vases contained bouquets of naturalistic flowers, and this leads us to the consideration of the manufacture of porcelain flowers at Vincennes, which was for a long time the most remunerative branch of its productions. We have no precise documentary evidence to prove whether the making of porcelain flowers was first practised at Meissen or at Vincennes, but we know that the Duc de Luynes considered it to be a French invention, and one in which the modellers at Vincennes attained extraordinary skill. An examination of the bouquets still preserved in the Sèvres Museum, shows that they imitated roses, pinks, anemones and jonquils with rare perfection; the rich and luscious glaze of the soft-paste porcelain giving the colours a bloom approaching to the natural one. It is not surprising that these productions had an enormous vogue, considering that they could be applied to branched-candlesticks, lights, brackets, inkstands or vases, which were so perfectly in keeping with the affected and fanciful furniture of the day. We need not quote the eulogistic verses written in praise of the porcelain flowers, but we may quote from the memoirs of the Marquis d'Argenson, where he tells us :- "The King has ordered from the Vincennes works porcelain flowers, naturally painted, with their vases-more than 800,000 livres' worth-for all his country houses, and especially for the château of Bellevue of the Marquise de Pompadour. Nothing else is spoken of in Paris, and truly this unheard of luxury causes great scandal."

We may add to this account that of Soulavie in his memoirs of the Duc de Richelieu :- "Madame de Pompadour, doing the

* Compare the exotic birds so largely used on the porcelains of Chelsea, Bow and Worcester. See Burton's " History of English Porcelain," pp. 28, 112. 


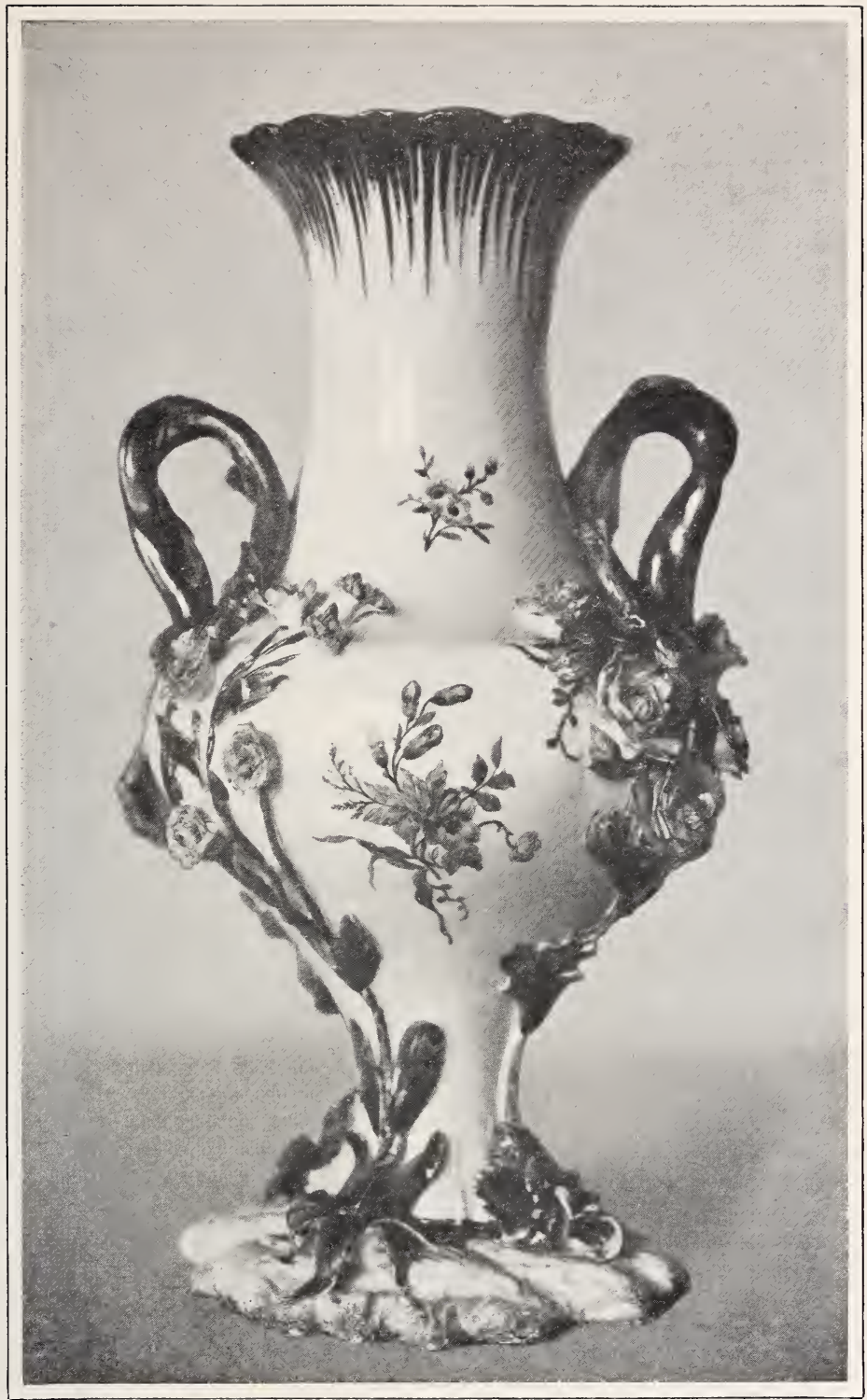

VINCENNES (Pâte tendre).

Fig. 16 -vase ornamented With flowers IN RELIEF AND WITH SPRAYS OF PAINTED FLOWERS PERIOD 1750.

H. 121 in.

Sèrres Museum. 

honours of her residence to the King, displayed before his eyes a whole flower garden. She expected him one day in this charming château of Bellevue, which had cost him so much, and when he entered it, she received him in an apartment at the far end of which was a hot-house with an immense flower bed, although it was a hard winter. As fresh roses, lilies and pinks predominated, the enraptured King could not sufficiently admire the beauty and the sweet scent of these flowers. But nature had been made game of. These vases, flowers, roses, lilies, pinks and their stems-everything was porcelain-and the sweet perfume of these heavenly flowers was the effect of their essences, volatilised by art."

In order to please the King the politic Dauphiness not only sent porcelain flowers to her father, the Elector of Saxony, but she also decorated (as the Journal of Lazare Duvaux, that repertory of the gossip of the period, tells us) her room at Versailles with a pair of sconces with three arms formed of branches, made to imitate nature, in the flowers of Vincennes.

"The tops of these branches are formed of lilies, tulips, jonquils, daffodils and blue hyacinths; the centre branches are of roses, the outer ones are of semi-double anemones, the minor ones of red wallflowers and violets; the junctions of the branches are decorated with different flowers, and the bases with buttercups and auriculas. The cups are of the same porcelain, with the sockets gilded with powdered gold. This pair of sconces cost the Dauphiness 1,200 livres. Another pair decorated with other flowers, such as tulips, cornflowers, orangeflowers, \&c., made in the same way, cost the same price."

It has been shown from the sale book of Vincennes that in 1749 such flowers and bouquets formed five-sixths of the output of the works. Naturalistic flowers were also used for ornamenting vases and table services. As an example of the pieces of this class we reproduce in Fig. 16 a vase from the Sèvres museum, which dates from 1750 . The modelled flowers on such pieces were, of course, coloured by the artists who painted the sprays on the body of the piece. Not only do we find sprays of flowers cleverly applied to the handles of the 
pieces, but the lids of covered vessels were often completed with a pile of flowers all skilfully modelled by hand (see Plate IV). This method of decoration was not only continued at Sèvres, after the removal from Vincennes, but was quickly imitated at Chantilly, Mennecy - Villeroy, and, indeed, at every porcelain factory of the latter half of the eighteenth century, extending even to Bow and Chelsea and the other English works.

Of the more ordinary china-ware the works at Vincennes produced plates, cups and saucers, bowls, jugs, oval and round sugar-basins, butter-dishes, mustard-pots, watering-pots, candlesticks, snuff-boxes, flower-holders, and cheese-dishes. A few statuettes are also known, mostly of rustic figures painted in clear or opaque enamels. It seems from the sale-lists that these ordinary pieces were sold at a very modest price; for instance, a sugar bowl and tray in one piece, decorated with flowers, was priced at 42 livres. The same list shows us among the customers every one of eminence about the court, from the King and Queen downwards.

It seems probable that no definite mark was used during the early years of the undertaking, but a few pieces have been met with which from their early style should be attributed to this period although they bear the two interwoven "L's" of the later period. Sometimes the two letters stand by themselves, with a point (.) in the middle. 
PLATE IV.

VINCENNES or StitVRES

(PÂTE TENDRE, ABOUT 1755).

\section{Oval Pot-pourri Vase,}

Apple-Green Ground, decorated with Cupids aFter Boucher. The Lid is decorated with Modelled Flowers, Painted in Colours; Pedrastal of Bronze, Gilded.

Wallace Collection, No. 162, Gallery XVIII. 



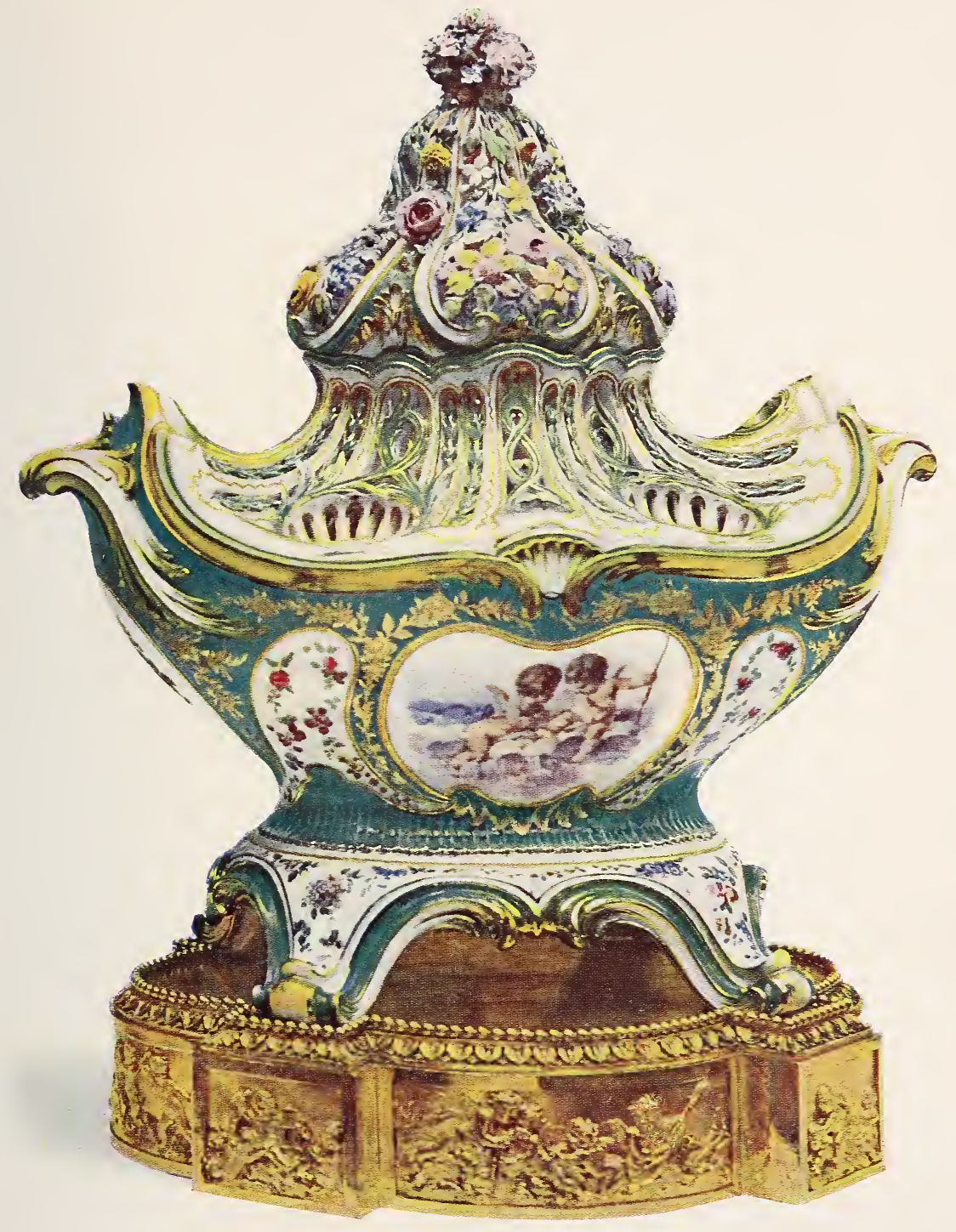





\section{CHAPTER VII.}

\section{VINCENNES: A ROYAL MANUFACTORY.}

The death of Orry de Fulvy had, of necessity, a profound influence on the fate of the enterprise we have just been considering. By the articles of association of the company it was necessary to pay out De Fulvy's shares, but there was no money in the coffers of the company for any such purpose, while large sums were owing to the Crown which could not be paid. Negotiations were entered into with the King's Council which resulted in an edict of October 8th, 1752, which took the privilege from Charles Adam, in whose name it had originally been granted, while a fresh edict of August 19th, 1753, restored the privilege in the name of Eloi Brichard, and became, in a way, the warrant which constituted Vincennes a royal manufactory. To Eloi Brichard, as representing the company, was given the right to conduct the works and produce all kinds of porcelain pieces painted or not painted, gilded or not gilded, plain or with modelled reliefs or flowers, and to enjoy and possess these rights and privileges to the exclusion of all others in the whole of His Majesty's obedient land and territories during twelve years and three months from October 1st, 1752. By this edict it was not only forbidden to any person, whatsoever his title or position, to make and sell porcelain, but also it was forbidden to paint any white-paste pottery in colours. Eloi Brichard was also given the right of inspection of all the other pottery manufactories, and he was given the right to inspect even the royal residences; while it was finally decreed that anyone importing porcelains from abroad was punishable with a 
fine of 3,000 livres and the confiscation of the imported porcelain. These powers do not appear to have been used at first, but we shall see in a subsequent chapter that they were revived and extended at a later date, after the removal of the royal factory to Sèvres.

Brichard was also allowed to use all the places and offices at Vincennes until such time as the manufactory could be transported into new and more commodious premises, but the establishment was declared a royal manufactory, with all the rights and privileges pertaining to the title, while on its front, and the front of its warehouse, the words "Manufacture Royale de Porcelaine" were to be displayed. It was further decreed that the pieces were to be marked with a double "L," which was to be put on every piece with the exception of flowers, on which it would be impossible to place such a mark. The secret of the composition of the materials, and of the painting and the modelling, was expressly reserved to His Majesty, and Brichard and his company were not to have any claim or property in such information, as the mixtures were to be made by some person appointed by the King in Council. To secure the personnel, which seems to have been a constant pre-occupation of the managers of all the porcelain factories during the eighteenth century, the workpeople and assistants who had been employed for six months were to be freed from certain imposts, such as police dues, the billeting of soldiers, and liabilities to militia service, while they were equally released from the ordinary and extraordinary taxation; any foreign workmen were to become naturalised and to enjoy the rights of native-born subjects. In return for this it was decreed that the painters, sculptors, or other workpeople must not leave without six months' notice, while those employed in the management, or special processes of mixing materials, colours, \&c., were not to be allowed to leave without special permission of the King. Even after having left the manufactory the workpeople were forbidden to employ themselves again in the manufacture of porcelain, while other porcelain or faience-makers were also forbidden to take them into their service, save with the express permission of the Council of State. All these restrictions were decreed under appropriate 


\section{PLATE V.}

\section{SEेVRES}

(PÂTE TENDRE, ABOUT 1756).

\section{Pierced Vase-Jardinière with Dolphins.}

Rich Turquoise Blue Ground with Gilding and Paintinge of Exotic Birds. Pedestal of Bronze, Gilded.

Wallace Collection, No. 10, Gallery XV. 



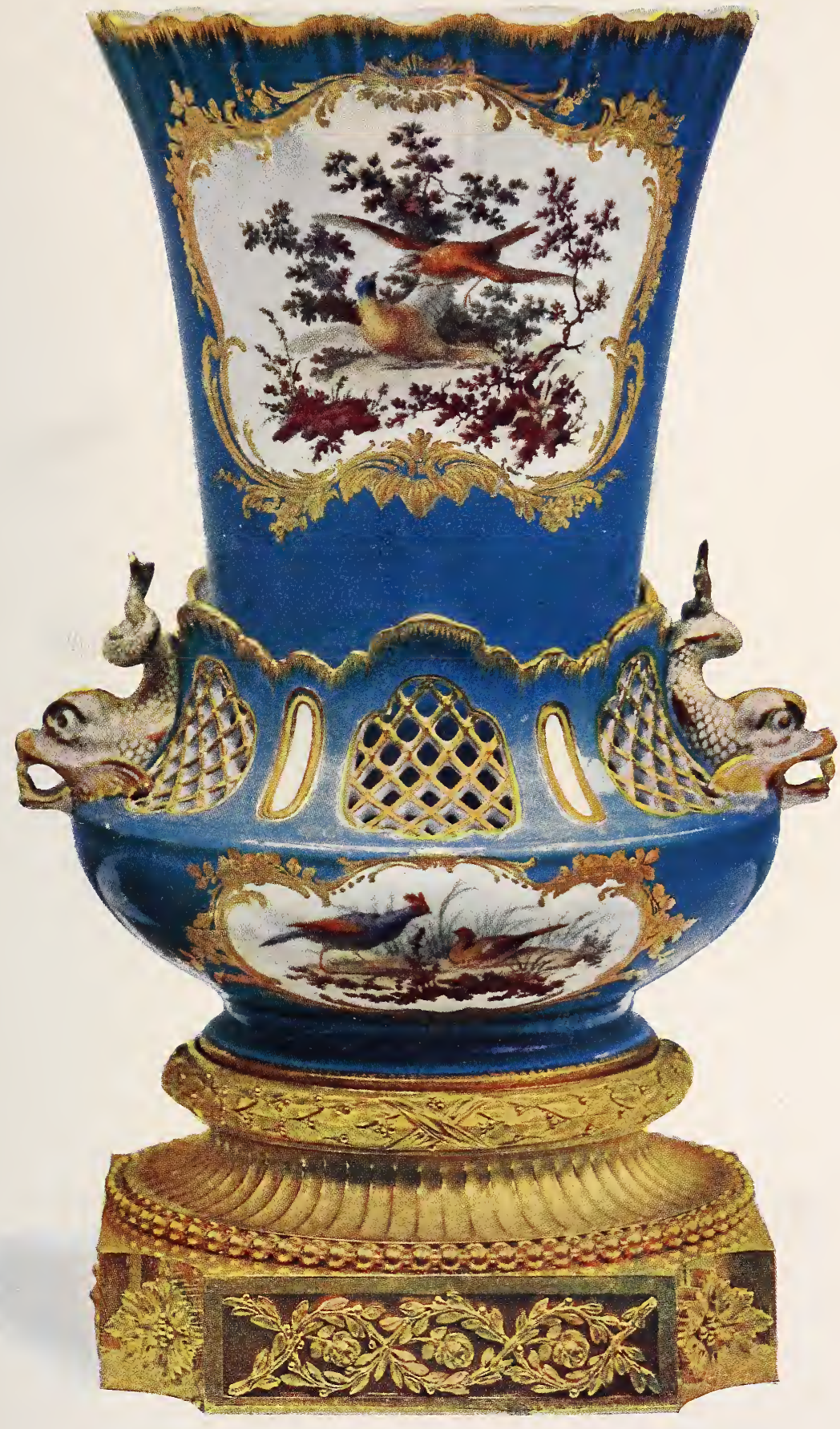


penalties including both fines and imprisonment, while all the former privileges to other factories were revoked. It is amazing to us, nowadays, to reflect on such a state of affairs, and to consider what must have been the condition of the country when the King could propose to reserve to himself such an exclusive monopoly.

To place the business on a satisfactory financial footing thirteen of the original shareholders subscribed for sixty new shares, depositing the sum of 600,000 livres, while the King for his part subscribed 200,000 livres with the right to one-quarter of the profits. The personnel of the works was increased, while the famous chemist, Macquer, became associated with Hellot, and from these changes we may date a rapid advance in the prosperity of the company. New colours were continually being discovered, and to this period we must attribute the introduction of many varieties of blue, yellowish-green, rose, lilac and yellow, while a variety of shades of soft rose, bright red, bright carmine, green, brown, grey, and bluish tints were also produced. This had a great effect on the finish of the painting, so that we find the highly conventionalised touch of the painting of the first period of Vincennes replaced by more elaborate work, in which the tints were shaded so as to give more completely the effect of roundness, and even stippling was resorted to. Toward 1749 the famous ground colour "Bleu de Roi" made its appearance; a magnificent under-glaze cobalt blue, so splendid and rich that it was found necessary to soften it by marbling, or relieving it with gold net-work. About 1752 Hellot introduced for the first time turquoise, or "bleu turquin," of such perfection on the beautiful glaze of Vincennes that it is found impossible to-day to reproduce it with such purity and charm of colour (see Plate V.). In contradistinction to the "bleu de roi" it may be remarked that this turquoise was an "enamel" colour placed on the already-fired glaze.

We have previously referred to a manuscript of Hellot's preserved at the Sèvres manufactory and entitled "Recueil de tous les procédés de la porcelaine de la Manufacture royale de Vincennes décrits pour le Roy, Sa Majesté s'en étant réservéle 
secret par arrêté du 19 Aout, 1753," which gives us much information of the materials and processes in use at this time, though it is perfectly clear that the names of some of the colours have changed since that period. Hellot says:- "To make porcelain of a fine solid white grain, like squeezed snow, similar to the old Chinese porcelain that one calls 'old Japan,' one must have a ratural or mixed clay which, after exposure for some hours to a very fierce heat, comes out white without being vitrified, and even without being hardened to such a degree that it will strike fire with steel. The ordinary clays of the nature of pipe-clay, white as they may appear, cannot be used for this purpose. I have tried all these clays, and though when mixed with white calcined sand and fired in a very hot oven they. become semi-transparent, they are generally of a dirty or tawny white colour, and only a very small number of the pieces come out of the oven without being crooked or bent; in a word they do not produce porcelain. The true kaolin, and the true petuntse that the Chinese make their porcelains with, according to the accounts of the Jesuit missionary, Duhalde, have not been found in France. M. de Réaumur and M. Guettard, of the Academy of Sciences, thought they had each separately discovered the secret of making porcelain, but their discoveries, proclaimed with great confidence, have been nothing more than mere experimental successes. Their porcelains resisted fire just as well as the Chinese, which was truly a great advantage, but they have never been able to give it the whiteness of the old Japanese porcelain." Hellot goes on to say that "M. Gravant's paste (the old paste of Vincennes) produced a biscuit of the same grain as that of the Chantilly porcelain, but much whiter, and that to glaze it it is only necessary to use a perfectly transparent flint glass, while to glaze that of Chantilly a kind of opaque faïence glaze had always been used. Both porcelains have the grain of the Japanese, although appearing a little less fine if they are exannined through a lens. The Saxon porcelain is not a true porcelain except from the outside; when it is broken it will be readily discovered that it is only a white enamel, but harder than the ordinary white enamel in general use." 

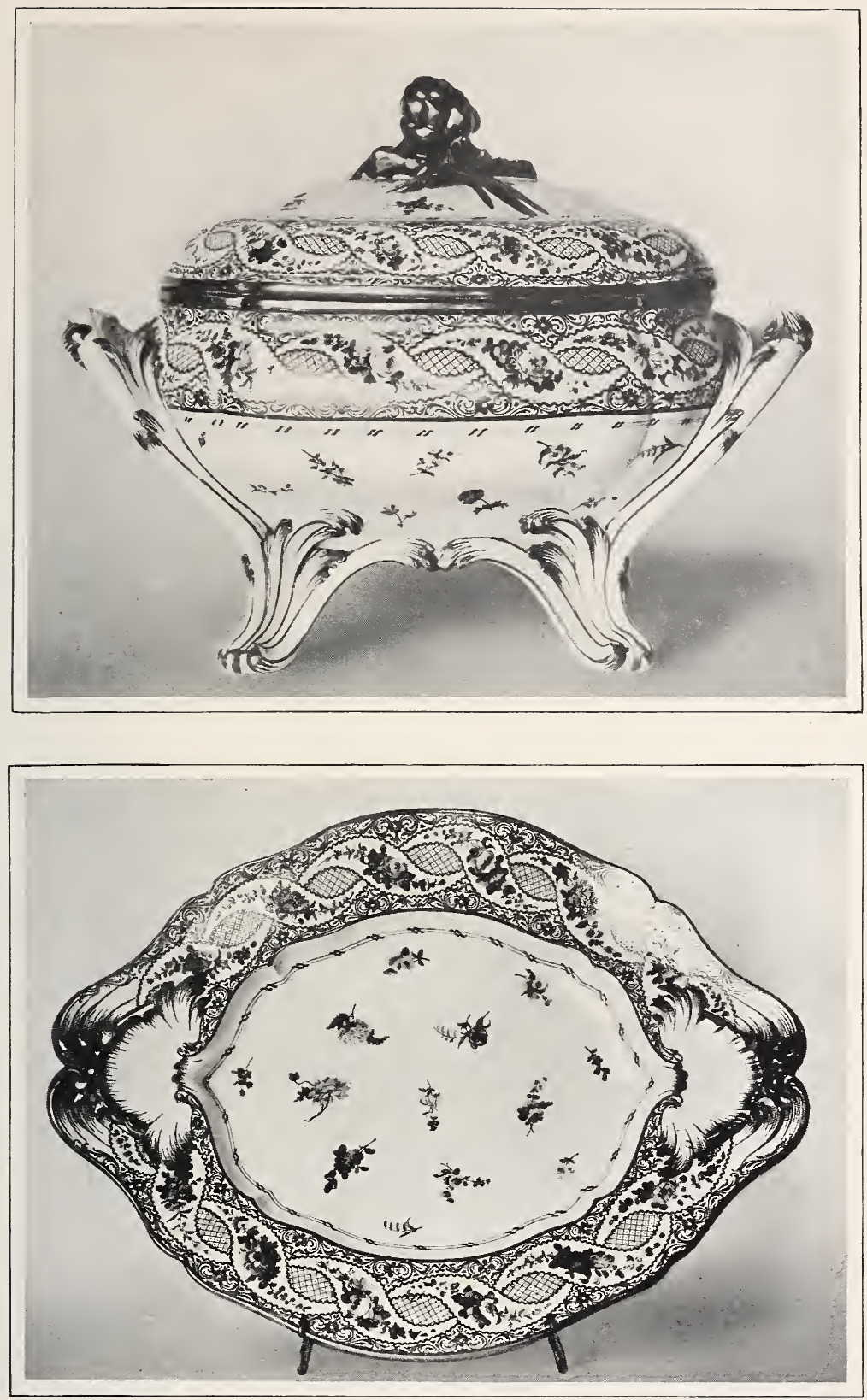

Sìvres (Pâte tendre).

Figs. $17 \&$ \& 18 . - SOUP TUREeN AND STAND MODELLED BY DUPLESSIS IN 1754. DECORATED 1772.

Tureen, H. $9 \frac{5}{8}$ in. L. 13 in.

Stand, L. $18 \frac{1}{2}$ in. W. $14 \frac{1}{2}$ in.

Sèrres Museum. 

This latter quotation shows the prejudice of even such a learned man as Hellot when he was dealing with the productions of a rival manufactory. The Saxon porcelain is undoubtedly a true porcelain like that of the Chinese, and is in no sense a mere vitrified enamel as Hellot suggests, but, these mistakes apart, his manuscript is of the utmost value, and when he compares the frit of the soft-paste porcelain to the petuntse used by the Chinese, which he calls a natural frit, and when he states that the calcareous marl used in France replaces the kaolin, "a sort of talc that does not become vitrified in the fire," he shows that he had perfectly grasped the fundamental idea of Oriental porcelain, which he was striving to imitate by the use of artificial substances.

We have quoted this manuscript at some length because of the interesting light it throws on the condition of affairs at Vincennes at the moment; but the time was come when it was deemed necessary to move the works nearer to the court, and to find a more convenient situation, and, if possible, one provided with water-power which could be used to grind the frits and the glazes which were so excessively costly at Vincennes. How this removal was brought about, and the royal factory established at Sèvres, we shall relate in the next chapter, but before doing so we must speak of the productions of Vincennes from 1752 to 1756, while it was a royal manufactory-productions so remarkable and exceptional that it is astonishing that they have never secured the attention they deserve.

The sculptor Duplessis designed the models for a series of table-pieces, largely based on the silversmith's work of the period; but we may well ask to-day if anything more delightful than his plates with embossed borders, or his soup-tureens and vegetable-dishes, has ever been made. We illustrate in Figs. 17 and 18 a soup-tureen and its stand, modelled by Duplessis in 1754, though the painting on these pieces only dates from 1772 , in which we may admire both the purity and elegance of the forms, and the courage of the daring manufacturer who ventured to make pieces with such fine oval profiles. This sculptor was proud to put his mark on the handles of cups 
or the models of cream jugs or milk pots, while at the same time distinguished painters were prepared to devote themselves to the charming art of painting on the soft-paste porcelain of Vincennes.

From this time, too, we must date the wonderfully modelled groups and busts so extensively reproduced in "biscuit" porcelain. We propose to treat of this subject in greater detail in a subsequent chapter in connection with Sèvres, but as the "biscuit" pieces are very seldom marked, it is often difficult to decide whether they were first produced at Vincennes or at Sèvres. These groups and figures, although designed primarily to be executed in "biscuit," are sometimes met with covered with a clear, white and transparent glaze. M. le Comte de Chavagnac, the learned collector of French soft-paste porcelains, possesses two groups of children made by the celebrated sculptor La Rue, which are thus glazed, and which from every point of view, whether as an artistic interpretation and rendering of the model, or as an example of perfection in firing and glazing, form the finest examples produced by this famous factory. It is interesting to remark that these groups were given by Louis $\mathrm{XV}$. to M. de Machault, his naval and finance minister, on the 31st December, 1754 , and since that time they have remained in the family, of which M. le Comte de Chavagnac is a descendant. The end of this most brilliant period of the Vincennes factory was signalised by the production of a service made for the Queen-Empress to show the superiority of French porcelain over that of all other European countries.

It should be remarked that the directors several times made perquisitions at other works or sale rooms, and confiscated the work and imprisoned various workmen and artists who devoted themselves in their own time to the decoration of the porcelain of other manufactories.

We have already stated that the mark was to be composed of two interlaced "L's," forming the royal cypher, but the pieces of 1753 bore a letter "A" between the two "L's"; those of 1754 the letter "B"; and this method of dating the pieces was followed at Vincennes, and afterwards at Sèvres, until the revolu- 
tionary period. It should be added that the potters generally impressed their personal mark or initial into the paste, while the painters and gilders, when finishing the piece, likewise added a mark or a painted monogram to distinguish their work. The pieces intended for the King's own service, and those that were to be given by the monarch as presents, had sometimes a "fleurde-lys" over the cypher (see Section on "Marks"). 


\section{CHAPTER VIII.}

THE ROYAL MANUFACTORY OF SOFT PORCELAIN AT SÈVRES, 1756-1769.

THE manuscript of Millot, preserved at Sèvres, tells us that M. Verdun, one of the shareholders of the royal manufactory of Vincennes, who was acquainted with Madame de Pompadour, strove to interest her in the fate of the manufactory. It did not take Madame de Pompadour long to choose a piece of ground, next to a glass works which the King had formerly given her the right of using, and this property was conveyed to the company for 30,000 livres; the glass works being used to lodge some of the workmen. The King bought an old château of the musician, Lully, called "La Diarme," situated near the road leading from Versailles to Paris, by the side of a little hill, but in very wet land, full of springs. Madame de Pompadour selected as architect a surveyor, Lindel, whose first work as an architect this was. Instead of building on the level a commodious and convenient works, he erected a sort of palace of three storeys, one part of which was built on made ground, so that it was necessary to carry the building on arches to resist the pressure caused by infiltration of water. The works was so inconvenient and badly planned that the workpeople lost endless time in going from storey to storey; while the buildings were so damp that it was difficult to work in some of the rooms. Madame de Pompadour, with her accustomed diplomacy, had caused Lindel to build a summer-house containing a suite of rooms for the King; for, knowing his frivolous character, she relied on this means of securing his interest in the 


\section{PLATE VI.}

\section{SÈVRES}

(PÂTE TENDRE, ABOUT 1758-59).

\section{Vase-Jardinière on a Pedestal.}

Ground of Rose-Pompadour with Bands of Vert fonct. FlowerPAINTING BY BERTRAND.

Wallace Collection, No. 118, Gallery XII. 



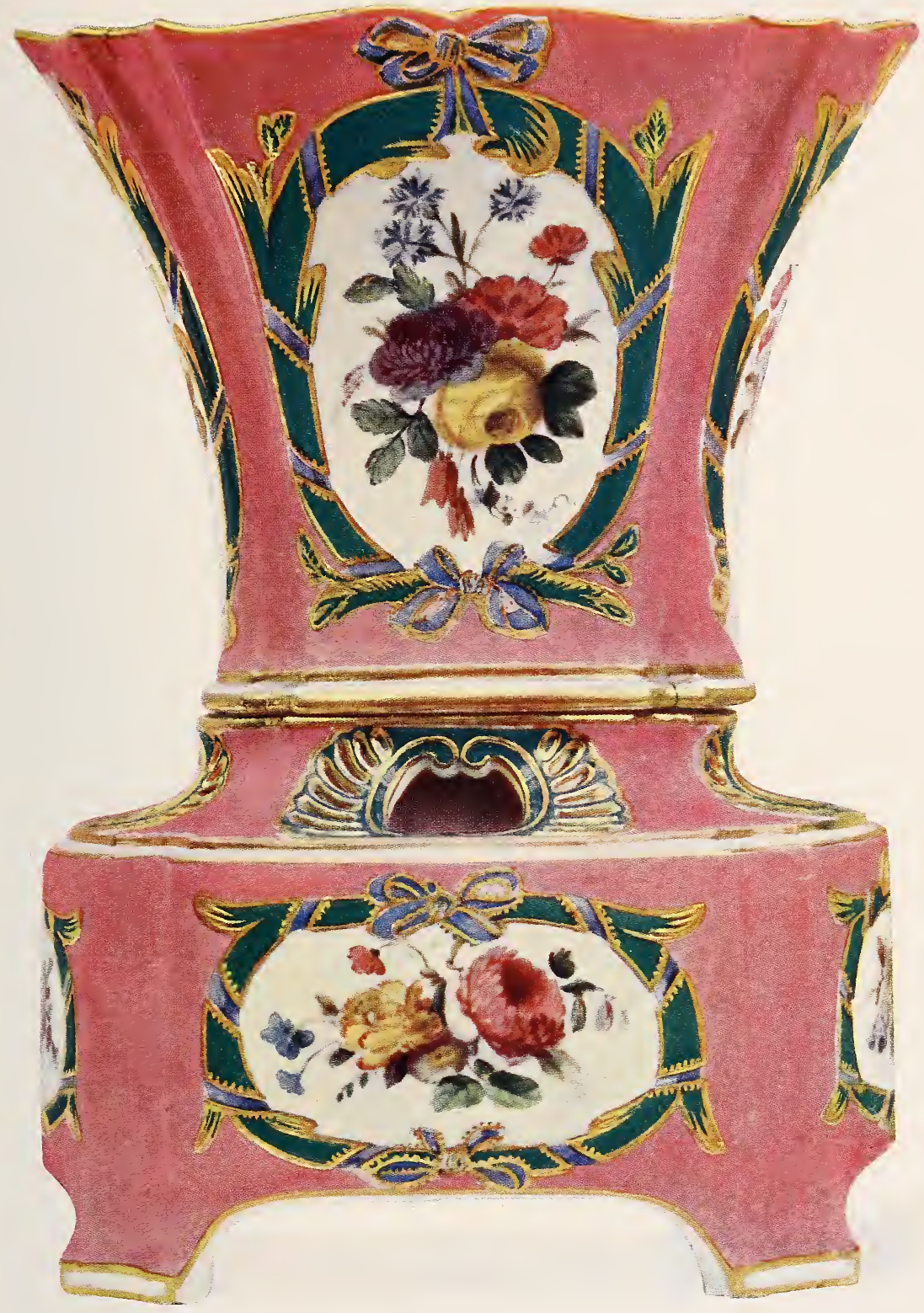



operations, and reckoned on thus leading him to consider the whole establishment at Sèvres as his affair. The Duc de Luynes describes this little establishment of the King's as follows:- "I went a little while ago to see this manufactory at Sèvres. The master builders have made a suite for the King composed of a big anteroom that would be serviceable for his guards; on the left side is a large chapel, the altar of which can be seen from every apartment in the suite. Next to the chapel is a large room and a very large cabinet."

Other rooms that were built for the eminent artists employed were not used for that purpose, but were placed at the service of friends of the directors. Afterwards, as it was apparent that the glass works used for lodging some of the workpeople was very near the royal apartments, it was allowed to fall into ruins, and the workpeople were paid lodging money instead. M. le Duc de Luynes gives us this further account of the works at Sèvres at this period: "Beneath the building are large cellars, all strongly vaulted, and light, and in the first storey there is an enormously long corridor which gives air and light to the different rooms, which are of various sizes according to the kind and number of the people employed in them. In the painting room there are sixty painters, who each work in different ateliers according to their different abilities, and different wages are paid to them also in proportion. Some of them earn as much as a louis a day, and the principal painter, who is at the head of the work, earns two louis. The work of the painters appears already to have been brought to great perfection. The white is very beautiful, but up to the present it has had the inconvenience of being very dear. The painting in blue increases this price considerably, and it is this species of porcelain which they sell to advantage. Vases to hold flowers in one's room are sold at 25 louis each, soup bowls for 50 louis, and coffee cups with the saucer at 2 louis each.

"The King's apartment was not yet furnished when I was there six weeks ago. They were also engaged in building a warehouse for displaying the porcelain for sale, but it was not yet open to the public. To obtain admission it is necessary to 
have a ticket from the general superintendent. There are now about five hundred workpeople, who will require to be lodged in this building when it is finished. This manufactory is quite different from that in Saxony, where before the invasion of the King of Prussia there were about 1,400 workpeople."

All the authors of this period complain of the high prices of the Sères porcelain. The Marquis d'Argenson says: "The Narquise de Pompadour is interested already, and interests the King:; but the pieces are sold at extravagant prices. The Saxon porcelain is better and cheaper, while that of China and Japan is cheaper still. Ours is sold to the merchants at 12 per cent. discount, but nobody buys it, though much is wasted on it; and thus everything is carried on beyond the funds of the undertaking."

This seems to have been a true criticism, for Lindel had spent 1,320,000 livres* in building this inconvenient manufactory, and, considering the conditions under which the place was worked by royal patronage, the prices were naturally bound to reach a high level. It is difficult to make soft porcelain; even when the oven has been filled the results are very doubtful. The time wasted in traversing corridors and staircases, and the difficulty of superintending such an ill-planned establishment all helped to increase the cost. Besides, it should be remarked that as the soft-paste porcelain of Sèvres was made thinner than had been the case before it was correspondingly more fragile, so that the agents and shopkeepers in Paris refused to push the sale of it unless they were given an allowance for breakage, and then it seems they got into a habit of hiring out Sèvres services for festivities, weddings, \&c. It will be obvious that under any such system of mismanagement the leakage must have been enormous. To avoid the difficulties of book-keeping it seems to have been the custom to charge the same price for the same shape irrespective of its decoration, so that a cup of a given size and shape, whether decorated by an apprentice or by a distinguished artist would be sold for the same sum.

* See First Register of the Expenses of the Court, or "The Red Book." Paris, 1793. 


\section{PLATE VII.}

\section{SÈVRES}

(PÂTE TENDRE, ABOUT 1761).

\section{Jardinière with Rose-Pompadour Ground.}

Decorated by Sinsson with Paintings of Cupids and Flowers; Rich Gilding.

H. $7 \frac{1}{2}$ in. W. 75 in.

Victoria and Albert Museum.

(Jones Bequest.) 



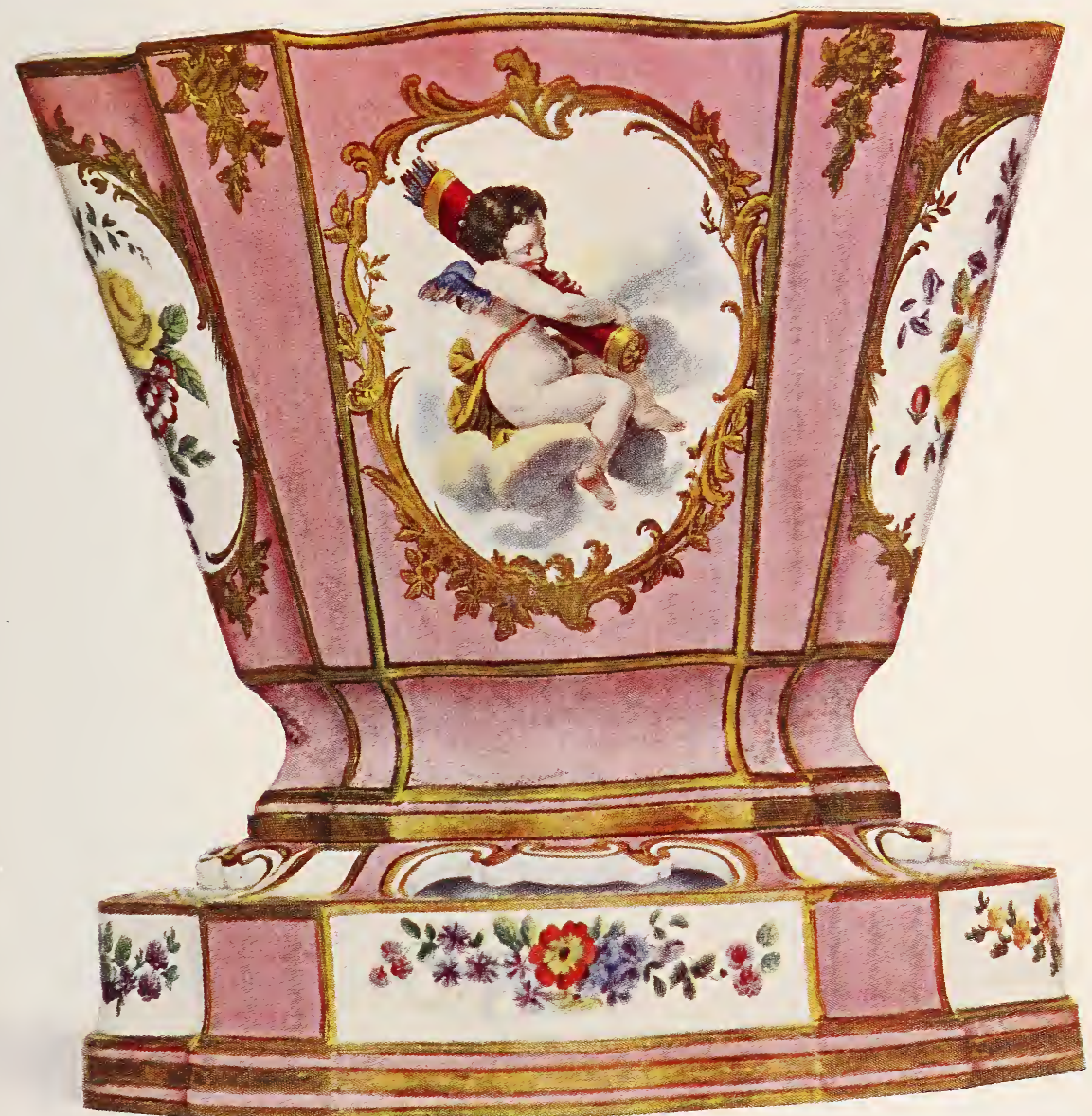





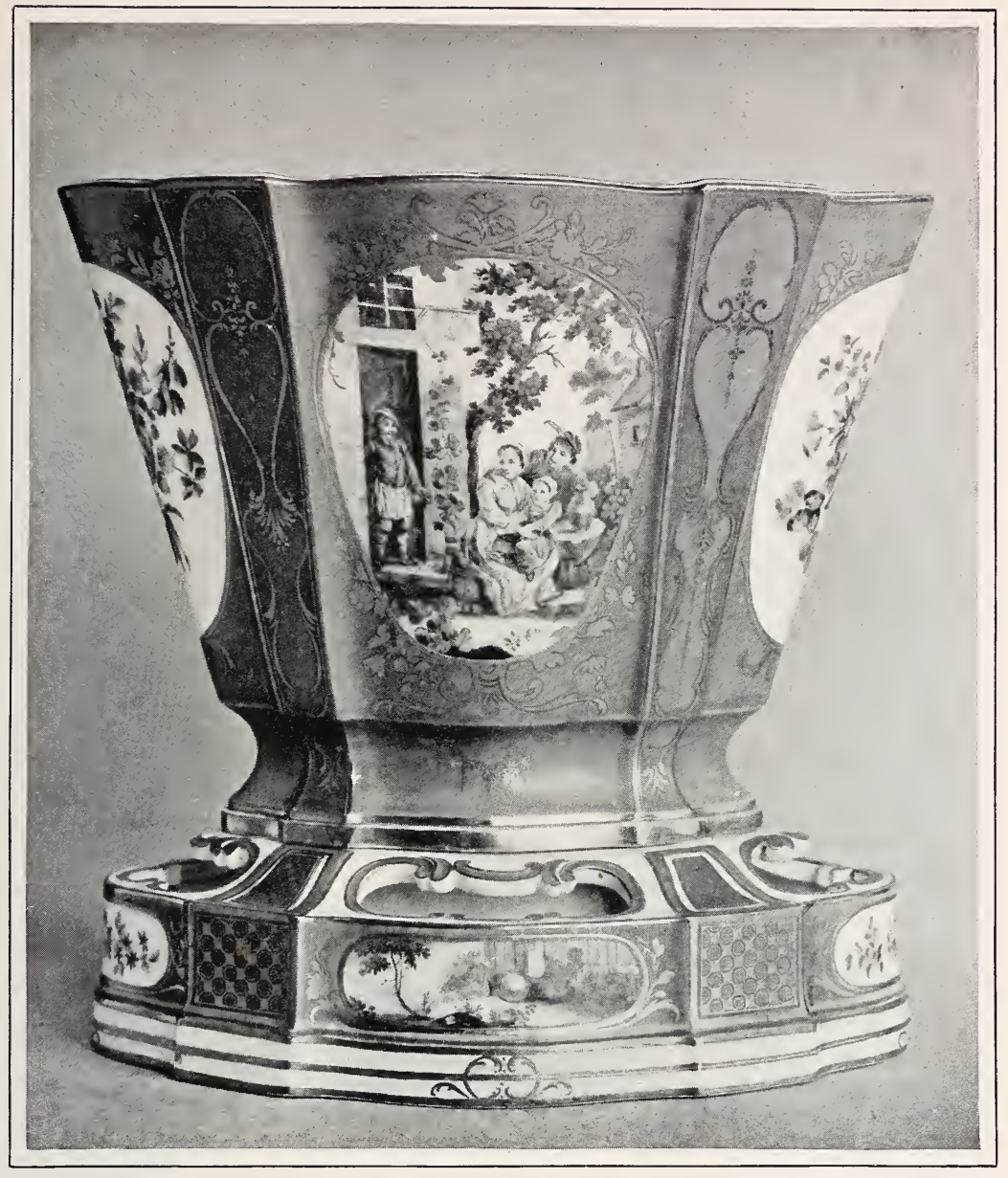

SÈvRES (Pâte tendre).

Fig. 19. -Jardinière With Green Ground, DECORATED WITH FIGURE SUBJECTS, FLOWERS, AND RICH GILDING. PERIOD 1759.

H. $7 \frac{1}{2}$ in. WV. $7 \frac{8}{4}$ in.

Jones Bequest. No. 174,

Victoria and Albert Museum. 

In spite of these defects in the organisation and administration of the factory, defects which would have ruined any private institution, it must be said that the Sèvres factory produced, between 1756-1769, when nothing but soft-paste porcelain was made, a very large number of pieces remarkable both for skill in execution and excellence in design. During the greater part of this period we can feel the influence of Madame de Pompadour, for before the settlement of the works at Sèvres she seems not to have been interested in the manufacture of porcelain. When she determined to make Sèvres into the royal manufactory, entirely supported by the State, the chemists and potters at Vincennes had already solved the difficult problems of practical production.

Let us quote again from the chronicles of that time. The Marquis d'Argenson tells us that:-_ Madame de Pompadour talks about nothing but the great advantage that the State will derive from the manufacture of porcelain in the Saxon fashion, and even in having excelled the Saxons in it. A royal shop for the sale of this porcelain is opened in the rue de la Monnaie, and there is exhibited a service which the King is going to send to the King of Saxony as if he wanted to bid him defiance, and provoke him by showing him that he had even excelled his porcelain manufacture. At one of the King's suppers the Marquise de Pompadour said that those who did not buy as much of this porcelain as they could afford were not good citizens, to which someone answered that 'Since the King had bestowed so many donations in the encouragement of this manufactory, those at Charleville and at St. Etienne for the manufacture of weapons, useful to us in another way, are neglected, and three-quarters of the workpeople go over to foreign countries." "

It was in this way that the manufactory became, through the interest of the Marquise de Pompadour and her friends, more and more a works entirely under the Crown. In spite of these successes it was, in May, 1755 , found necessary to call up the last tenth of the share capital, and in October, 1755, the company had to borrow 20,000 livres; while in December of the same year 
the Superintendent-General of Finance accorded to Sèvres, for its urgent needs, a sub-lease of the fees for the hall-marking of gold and silver plate, and the taxes on candle-grease in the town of Paris, at the rate of 730,000 livres, the profits of which were to go into its coffers. This was not sufficient, for before 1759 the loans had reached the total of 200,000 livres, and the promissory notes had to be renewed as they fell due. Finally, in November, 1759 , in order to avoid the liquidation of the establishment the King decided to take over the sole financial responsibility. An edict ordained that the manufactory should be administered for the King under the authority of Sieur de Barberie de Courteille, Councillor of State and Superintendent of the Finances. The shareholders of the company had the value of their shares returned to them in the shape of notes bearing interest at five per cent., and to enable the manufactory to meet the payment of these notes and the demands of the builders they were granted 1,320,000 livres in bonds on the Estates of Brittany, and the sum of 80,000 livres in ready money. It was thus that the King became proprieto: of the works at Sèvres.

We have already mentioned M. Boileau and his modest beginnings at Vincennes as managing clerk under Orry de Fulvy. This M. Boileau had grown with the growth of the business and had become so skilful and diplomatic that he knew how to go behind Madame de Pompadour and the ministers and approach the King in person, so as to make himself indispensable. He had managed to retain his influence even among the clashing interests of so many shareholders and so many ambitious heads of departments, and his experience of the methods, and knowledge of the details of the organisation, gave him exceptional facilities which he was not slow to improve.

As soon as Sèvres became a State establishment he took steps to assure its position above all the rival factories. What this position was supposed to be under a monarch like Louis $\mathrm{XV}$. will be seen by the edicts issued by the Lieutenant-General of Police, which forbade all persons, whatever their qualification 


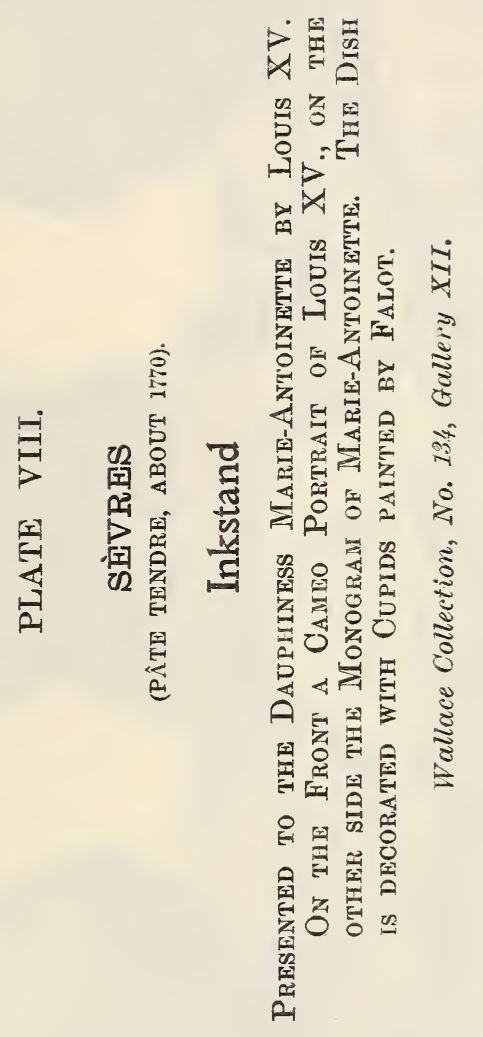





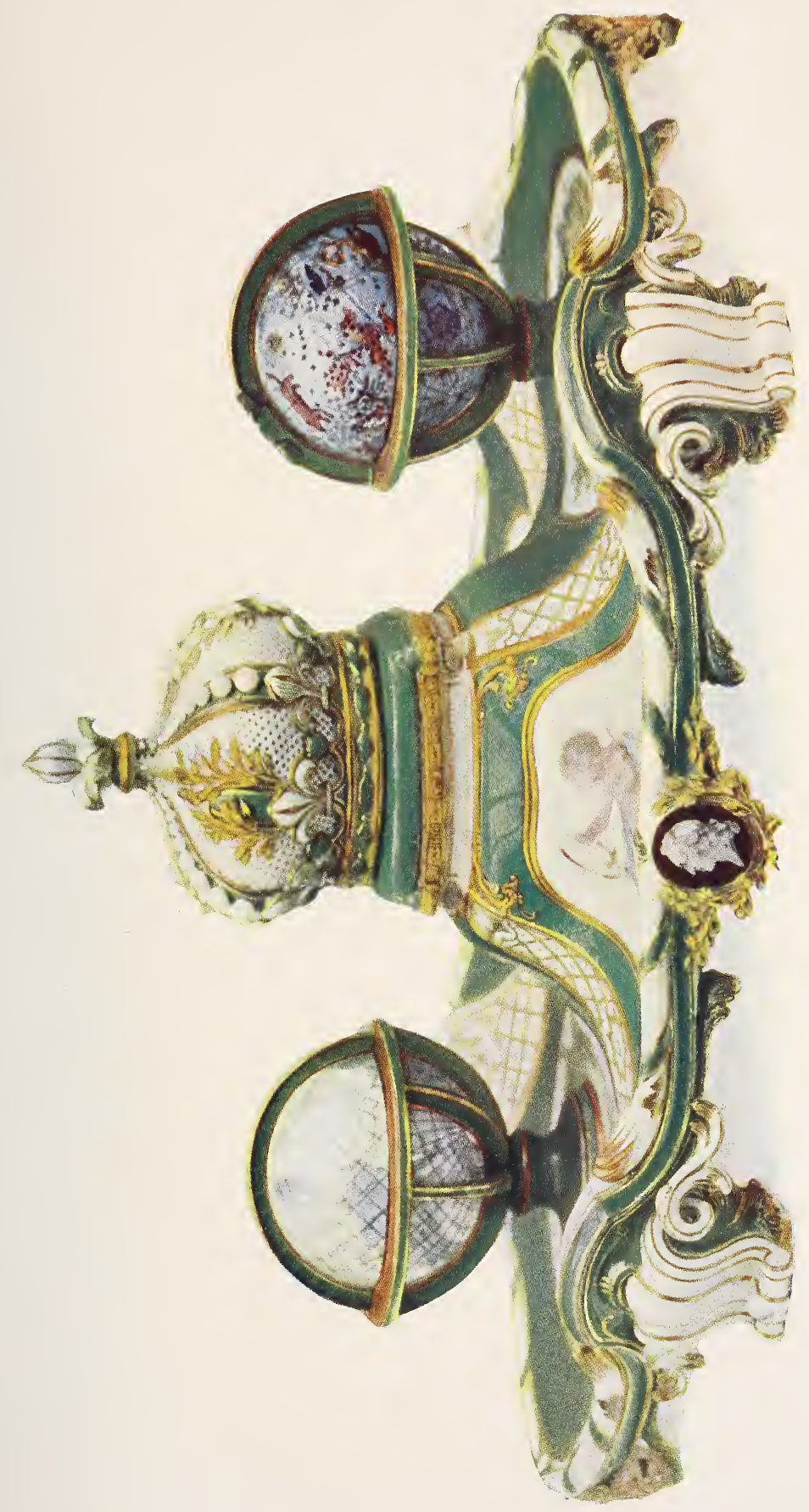



or position, to make, or cause to be made, to sculpture, paint, or gild porcelain pieces, in whatever form, or to sell or barter thein; on pain of confiscation of the porcelain itself, while the material used in its fabrication and the ovens should be destroyed, and a penalty of 3,000 livres exacted in addition, onethird to go to the Infirmary, one-third to the Royal Hospital, and the other third to the Royal Manufactory. In the same edict it was decreed that all those privileged manufacturers who made certain common porcelains, pottery of white paste, or faience painted in blue in the Chinese way were forbidden to use any other colour, and especially gilding, as well as the making of figures, flowers, and sculptured pieces, except as ornaments to their own wares. This rigorous enactment naturally caused a great outcry among the porcelain and faïence-makers, and as some of the other works, such as Chantilly and Mennecy, had powerful patrons, and the King was unwilling to lay waste so many factories and let so many workpeople starve, it was found necessary to issue, in February, 1766, a fresh decree which permitted throughout the kingdom the manufacture of porcelain, made in imitation of the Chinese, with such pastes as the managers of these works found necessary, either in white or painted in blue and white, or en camaïeu in one single colour, upon the condition that each manager should paint, engrave, or stamp on the back of each of his pieces the initials of his name or some other mark which he must register before a magistrate, and promise only to use. The managers of these works were expressly forbidden, under pretence of this leave, to paint their porcelain in any other colours than blue, or en camaïeu in one colour, or to use gold, put on or inlaid "until it is ordered otherwise," and they were expressly forbidden to make statues, figures, or ornaments in alto-relievo with porcelain paste, either "biscuit" or glazed.

These severe edicts enable us to understand why at this epoch the products of Chantilly and Mennecy are exclusively painted in blue or occasionally decorated en camaïen, but it is difficult for us nowadays to explain why such restrictive measures should have been applied to an industry which it was 
intended to develop in order to increase the prosperity of the country. It is certain that several of the rival French works had to discharge a great many of their workpeople, and that others, prevented from imitating the flower pieces and statuary groups of Saxony, only lingered on a few years before they, too, died out.

Even these unheard-of restrictions did not inumediately succeed in bringing financial success to the royal establishment. In 1763 there was again a deficit of 96,000 livres. This deficit was met by the King, and from this time he undertook to provide for the manufactory out of his privy-purse.

It is from this period, however, that we must date the most glorious productions of soft porcelain at Sèvres, and it is only in the collections of His Majesty the King of England, in the Wallace Collection preserved in Hertford House, or in the collections belonging to the Rothschild family, that anyone can form an idea of the magnificence of the productions of Sèvres during the next ten years. Most of the pieces appear to have been intended for the King's service, for the furnishing of the royal palaces of Versailles, the Trianon, Marly, Bellevue, Meudon, St. Germain, and Fontainebleau. He used them as presents for his relatives, his friends, his courtiers, and his ambassadors. They were also made use of as diplomatic presents, sometimes perhaps, as diplomatic bribes. Like Louis XIV., Louis XV. was also obliged to send all his silver to the mint twice during this period of national distress, and the courtiers had become quite accustomed to the use of faïence and of porcelain; thus Sèvres profited by the deplorable state of the country's finances. Besides dinner-services of simple or elaborate form in the style of Duplessis; besides the small tea- and coffee-services, the trays, the sugar-basins, and the milk-pots which are so vastly admired nowadays; besides a thousand more trifling things such as tobacco- or snuff-boxes, watch-cases, thimbles, buttons, heads of canes, patch-boxes, ointment- and perfume-pots, needle-cases, bonbonnières, and boxes for counters, we find an enormous production of vases, designed by architects and sculptors of eminence, the importance and beauty of which astound us. 


\title{
PLATE IX.
}

\author{
SÈVRES \\ (PÂTE TENDRE, ABOUT 1ī̄ît).
}

\section{Candlestick-vase with Elephants' Heads.}

Pale Blue-green Ground decorated with Rich Gilding and with Paintings of Cupids, in the Style of Boucher, by Dodix.

Wallace Collection, No. 145, Gallery XVIII. 



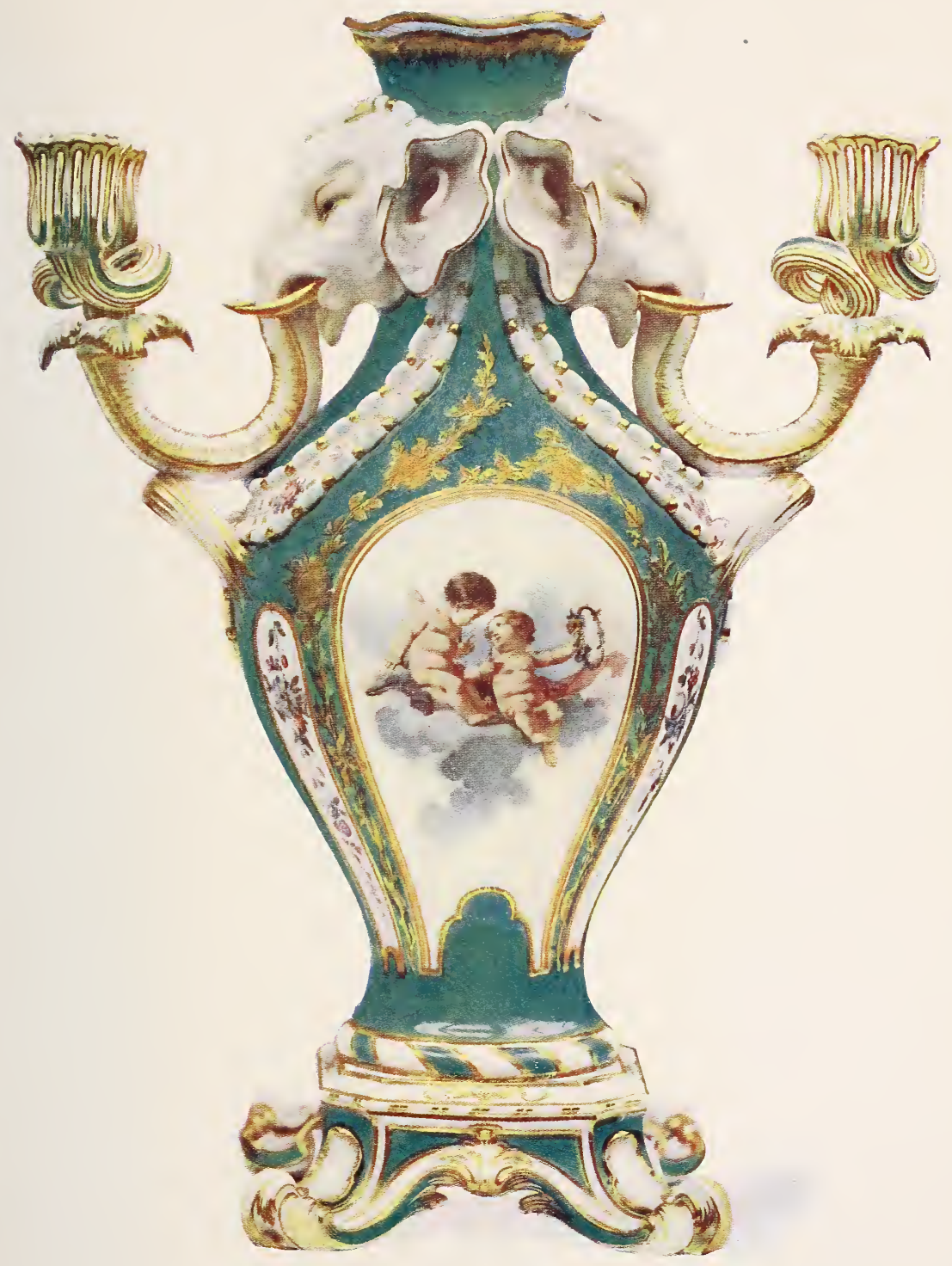



In the Wallace Collection there is a beautiful inkstand given by Louis XV. to the Dauphiness, Marie-Antoinette, which between the celestial and terrestrial globes bears the royal crown (see Plate VIII.). This and many other similar pieces of the utmost elegance and refinement convey to us a wonderful idea of the inventive genius of the decorators at Sèvres, and if we admire the taste and elegance of these pieces what are we to say of the technical skill displayed in their production? It was bold to render the horizontal or vertical lines of some architectural model in a material so easily deformed in the firing as this soft-paste porcelain, but it passes our knowledge to understand how they ever managed to maintain in the fire the pierced vases bearing dolphins (see Plate V.), the important table-centres like the Vaisseaux d̀ mât (see Plate I.), or the candlestick vases in the form of elephants' heads (see Plate IX.); all superb pieces, manifesting the tender translucent quality of soft-paste porcelain to perfection. These are miracles of technique which a porcelain-maker of the present day does not profess to understand, and when one considers the courage required to conceive such works, the beauty and delicacy of the shapes, and at the same time the quality and lustre of the material, it is safe to say that at no epoch have any similar tours de force been executed in pottery.

In addition to these elaborate and difficult shapes, we cannot but notice that the decorations are also richer and more sumptuous than those invented at Vincennes, for many new ground colours had been invented. In 1757 the painter Xrowet invented that most famous ground-colour, rose-Pompadour.* This colour, of a soft and harmonious flesh tint, is one of the most difficult colours to obtain, for let the temperature be a little too high and it becomes of a dirty yellow tone, while if fired at a low temperature it has an unpleasant brownish, mottled appearance. This volume contains several reproductions of pieces from the Wallace Collection, and one

* This colour has been erroneously called rose-Dubarry in England. 'The correct name is as here given, for Madame Dubarry was not introduced at court until 1770. 
from the Jones Bequest, on which this ground-colour is of exceptional quality. Even the reproductions will give the reader a good idea of its beautiful tone.

The "Bleu de Roi" was seldom used alone, but in order to soften its strident tone it was generally covered with gold

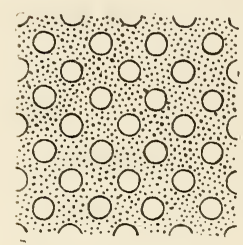

1

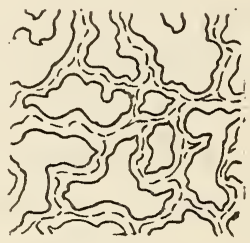

2

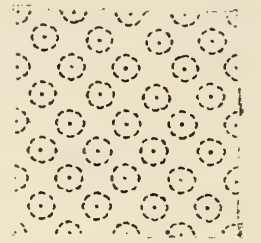

3

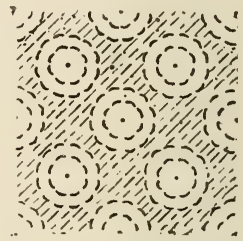

4

tracery in patterns of network (1), vermicelle (2) or seil-deperdrix (3).

In other examples white parts were reserved which were surrounded with colour, so that we have rosettes, for instance, surrounded by blue and gold circles (4). A lilac ground is very rare; the Sèvres Museum possesses some specimens of it, but apparently it was seldom successfully produced. The remaining ground-colours which date from this period are a fine yellow "jonquille," and two greens, vert pomme or vert jaune and vert pré or vert Anglais. These ground-colours are exceedingly well represented in the Wallace Collection and in the Victoria and Albert Museum (Jones Bequest) by pieces of the very first quality, and reproductions of some of the best pieces will be found in the coloured plates.

In addition to these grounds in one uniform colour we find a consicierable number of pieces having grounds of the type known as xeil-de-perdrix, formed by dotting sea-green, or bright blue colour, gilded, on a white ground, so as to break up the crudity of the white ground and give additional relief to a landscape or figure subject painted in a reserved medallion (see Figs. 20 and 21.)

Along with this improvement in the manufacture and colouring of the pieces, the painting itself also improved in delicacy and refinement; while the most brilliant red, lilac and 


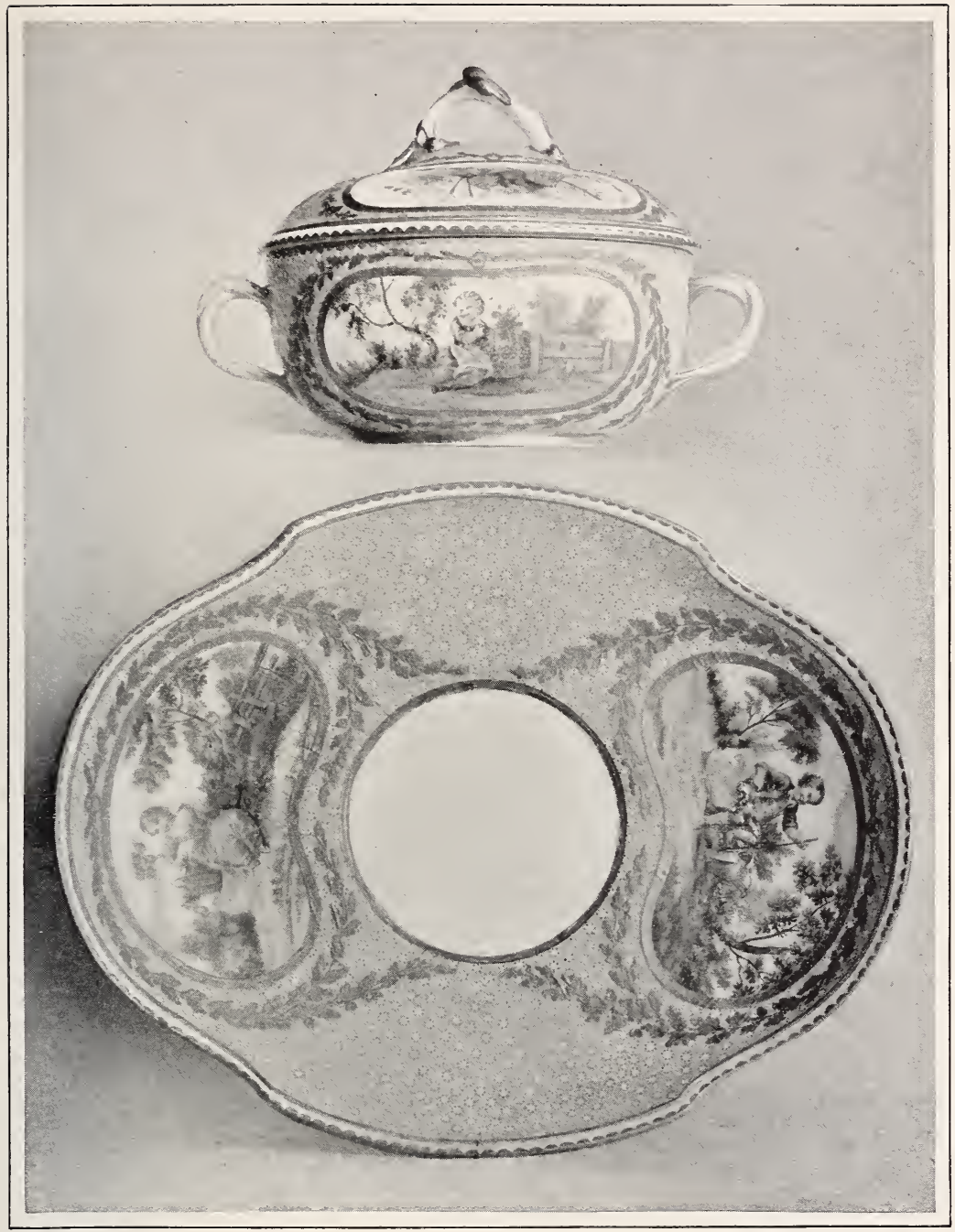

Sìvras (Pâte tendre).

Figs. $20 \&$ 21.-COVERed Bowl AND STAND: " EIL DE PERDRIX " GROUND.

Bowl, H. $4 \frac{1}{2}$ in. Dia. $5 \frac{1}{16}$ in.

Jones Bequest, No 166 ,

Victoria and Albert Museum. 



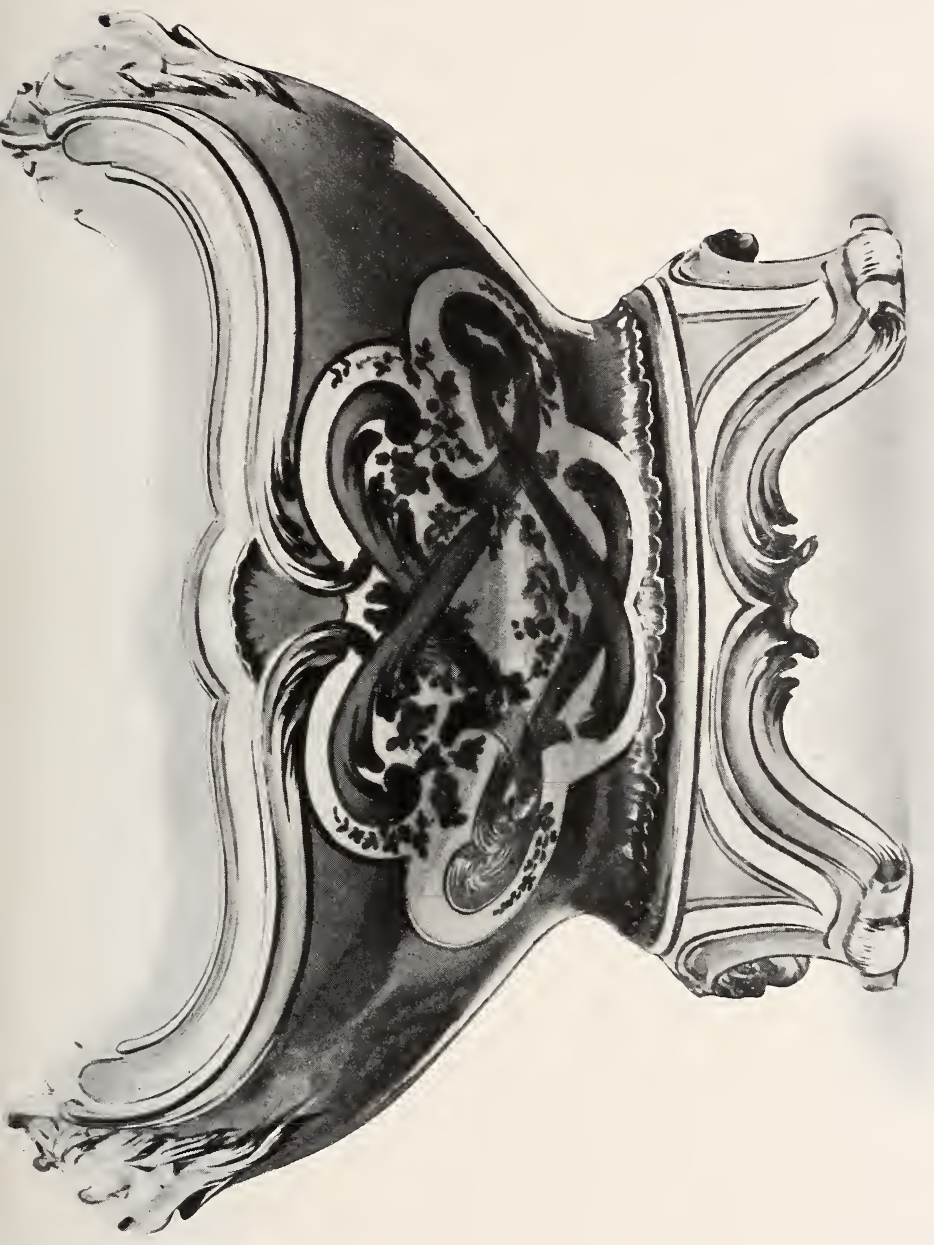

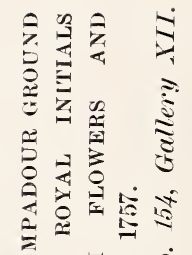

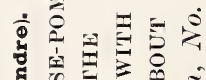

क

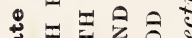

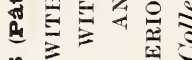

计

中国空.

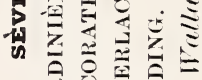

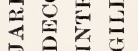

1

สุ่

突 

crimson colours harmonise well in the palette by the side of the blues, greens and yellows. Gold was used either in flat touches or in relief, made brilliant by skilful burnishing, so that it is not surprising that white pieces, decorated only with gold or with subjects painted en camaïeu in crimson, or soft blue, were highly esteemed; indeed, the success of the paintings en camcïeu of subjects including landscapes and country figures was enormous.

No longer do we find the Sèvres porcelain basing itself on Chinese interpretations or Saxon imitations. This wonderful golden reign of royal favour permitted the creation of a new style, of an original mode, which all the rival manufactories of Europe in their turn strove to imitate. The style of Boucher became the style of the soft-porcelain painters for many years, and every effort was made by the painters to avoid painting the same subject twice. If two services of the same kind had to be made they were painted with different subjects. All the pieces intended for the King bore a royal crown in one form or another. Thus we find a sumptuous vase in the Wallace Collection, with a turquoise ground, which has for its lid an emblematical crown richly embossed and gilded (see Plate XXIII.) while a small bowl kept at Sèvres is likewise covered with a lid, the knob of which is formed by a royal crown supported by dolphins. This latter piece was offered to the Dauphiness at the time of her accouchement, and this species of covered basin has taken from that time the name of Ecuelle d'Accouchée. The jardinière with a rose-Pompadour ground in the Wallace collection, which we reproduce in Fig. 22, has the royal cypher of the two interlaced "L's," painted on the piece.

In addition to paintings representing country scenes, we find, of course, scenes of gallantry or of love, mythological subjects, and even scenes of military life. Of this latter kind we may mention the vase of the battle of Fontenoy, with red marbled ground, the reserved medallions of which are decorated with scenes representing the battle; and a vase in the Wallace Collection (see Plate XIII.) which shows a scene in camp. Numberless examples might be cited which would show how 
perfectly we can trace from the Sèvres porcelain of the period the customs, fashions and caprices of the moment.

The King and Madame de Pompadour had also the idea of replacing the presents in silver which they made to ambassadors and foreign sovereigns by presents of the royal porcelain. From the Register of Foreign Affairs, and especially from the Journal of Lazare Duvaux, we see that by 1756 or 1757 this new form of present was in full vogue. The Count Moltke, of Copenhagen, received a service in white French porcelain painted in flowers, with blue borders, which consisted of a soup dish and two covered dishes, with their oval stands, worth altogether some 1,500 livres. Le Comte de Bernis, the Minister for Foreign Affairs, sent, in 1758, to Madame la Princesse de Zerbst a breakfast service of Gros bleu on a square tray in French porcelain of the value of 192 livres; a "celeste" blue milk-jug in its bowl, with pierced ornament, worth 300 livres; a large green pot-pourri jar, of a new form, with medallions painted with cupids and covered with a group of flowers, worth 1,200 livres; while the same minister sent to the Bishop of Laon, then ambassador at Rome, a group of several figures in the Boucher style in "biscuit," with a vase, worth 312 livres; two groups, less important, in the same style, also with vase, worth 306 livres; eight figures, paired so that they look at each other, to the value of 336 livres; fifteen new smaller figures, also paired, to the value of 540 livres, and eight other figures representing washerwomen, milkmen, flower-carriers, etc. The Sèvres Museum preserves a certain number of the models of these figures, either in "biscuit" or in terra-cotta, and these original models have undoubtedly a great charm of style. As an example, we may mention the model of a little washerwoman (see Fig. 32). The naturalness and the grace of this composition are in exquisite taste, and in the same series we find milkmen, flower-carriers, boatmen, a bird-catcher, etc.; but we must return to this subject of the "biscuit" figures in a special account in a subsequent chapter.

The period from 1756 to 1769 , which we have studied in this chapter, is essentially the period of Madame de Pompadour, 


\section{PLATE $X$.}

\section{SËVRES}

(PÂTE TENDRE, ABOUT 1765).

\section{Rose-water Ewer and Dish.}

Yellow Ground decorated with Rustic Scenes painted in Blue, ANd with Rich Gildivg.

Ewer-H. 65 in. Dia. 4 in.

Dish-L. $10 \frac{3}{4}$ in. W. $8 \frac{3}{8}$ in.

Victoria and Albert Museum.

(Jones Bequest.) 


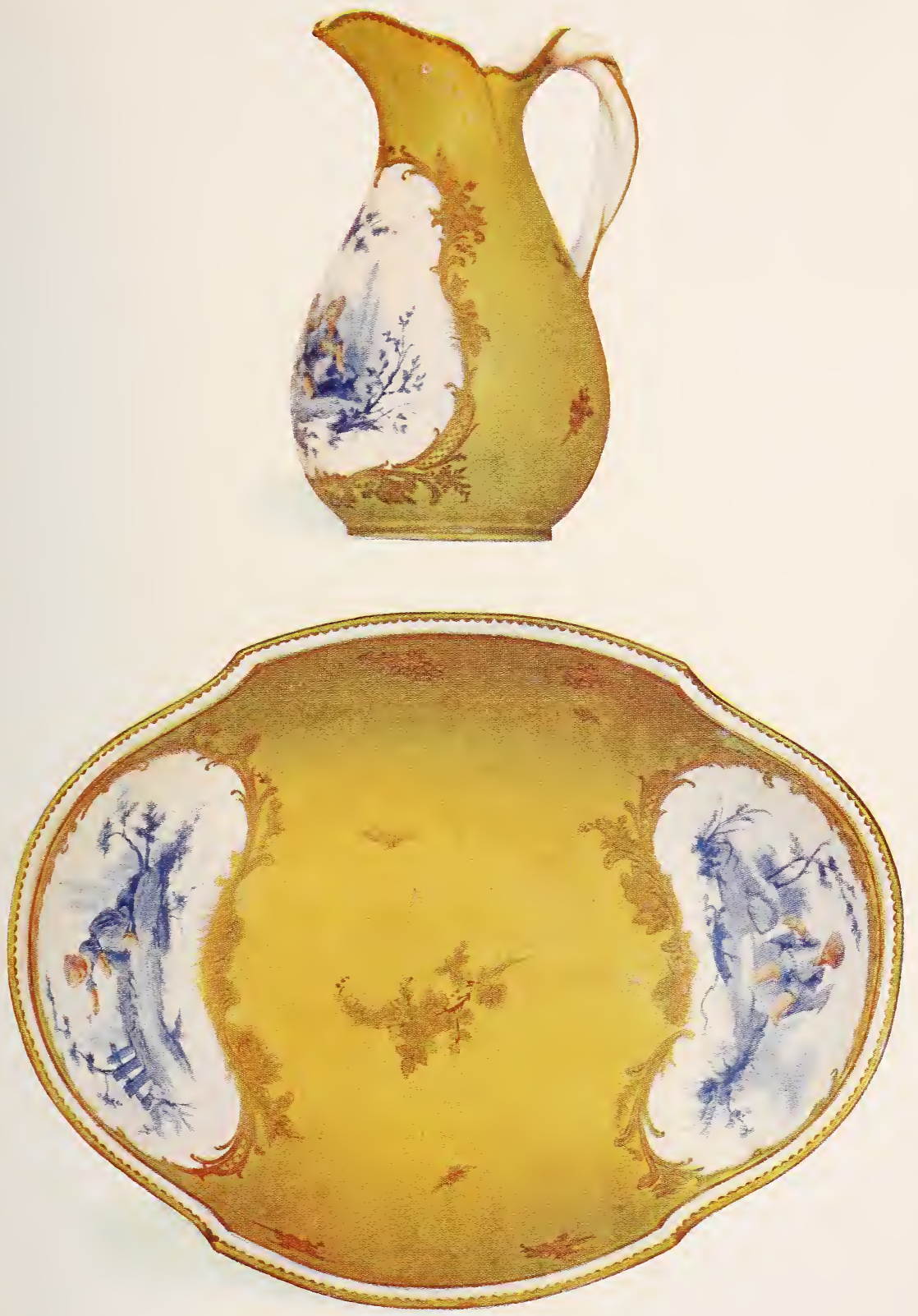

for although she died in 1764, her artistic influence was still preeminent. It was the sumptuous period of Sèvres in Louis XV. style, and while all the authors of that epoch have blamed the King for his extravagance in connection with Sèvres at a time when the affairs and credit of the State were in such a deplorable condition we can hardly now regret this extravagance, from which proceeded a French industry which is still so prosperous - that of hard-paste porcelain.

During this period, from 1756 to 1769, the mark consisted of the two interlaced "L's," between which the letters from D to Q indicated the year. In the year 1769 the appearance of a comet created such a sensation that the Sèvres decorators substituted the drawing of a comet for the letter " $R$ " as the index of that year. We shall give some information as to the personnel at Sèvres at this time in our account of the factory during the reign of Louis XVI., as a great number of the artists continued to work for years, during both reigns, without any modification in their style of work. 


\section{CHAPTER IX.}

THE ATTEMPTS TO PRODUCE HARD-PASTE PORCELAIN IN FRANCE.

Certainly the artificial soft-paste porcelain we have been describing, which may rightly be called French porcelain, was a beautiful decorative material, absolutely without a rival from the point of view of the china painter, for the colours painted upon it become so perfectly incorporated with the luscious glaze that its appearance is always sweet and charming; but this porcelain is difficult and costly to manufacture, while it readily cracks in use. The comparative cheapness of the Saxon and other German porcelains-for following the establishment of the works at Meissen, other porcelain factories had been started at Vienna, at Berlin, at Frankenthal, at Höchst, and even at Strasburg-their hardness, and their fire-resisting qualities rendered them serious competitors of the porcelain of Sèvres. The attention of the scientists connected with Sèrres was therefore turned to the search for hard-paste porcelain. The manuscript of Hellot, which we have already mentioned several times (see pp. 46,47,53-55), shows that the accounts sent from China, by the Jesuit missionaries, as to the Chinese fabrication of porcelain by means of a natural white plastic clay, kaolin, and a fusible rock, petuntse, had been thoroughly appreciated (see p. 55). It was the discovery of these minerals in Germany that led to the production of hard-paste porcelain at Meissen.

At this time there was in Strasburg a potter, CharlesFrançois Hannong, originally of Maestricht, who had lived at Mainz, and who had probably derived from Höchst, a suburb of Mainz, his knowledge of pottery. Originally a tobacco-pipe 
maker he became a skilful and successful potter, being made an alderman of the Company of Masons and Potters in 1718, while he was elected to a seat on the local senate in 1729 . In 1719 a potter named Wakenfeld, from Anspach, came to Strasburg and applied unsuccessfully to various potters to lend him an oven in order that he might produce hardpaste porcelain. Failing in this effort he applied to the Municipal Council, who granted him a piece of ground and a workshop, where he undertook to make faïence and porcelain, if they would procure for him the necessary clay and sand, and he exhibited various samples to prove his ability. This man had undoubtedly fled from Meissen in spite of the severe edicts of the Elector of Saxony, and, after failing miserably to carry out the processes in Bavaria, he finally came on to Strasburg to be safe from the persecution of the Elector. There is no doubt that Wakenfeld was perfectly acquainted with the processes in use at Meissen, but it was impossible that he could have expected to obtain the necessary kaolin and petuntse from Saxony, and there was little hope of his finding those materials on the left bank of the Rhine in the neighbourhood of Strasburg. After two years, just when the Strasburg Council had wearied of the fruitless experiments, Wakenfeld was taken up by Hannong, and their joint efforts were soon seen in the rapid development of Hannong's faience manufactory. Here they were on sure ground, for the immediate neighbourhood of Strasburg abounds in clays suitable for faïence-making, and from the basis of an assured faïence industry they could more easily pursue the experiments for hard-paste porcelain. That at this period they did more than make experiments in this direction we can hardly believe, although, in 1726 , Hannong is said to have presented his corporation with three dozen plates, two salad dishes, and three large dishes in fine white porcelain. Economic reasons naturally developed the faïence industry, so that Hannong soon started another factory in Haguenau. Finally, in 1732, feeling himself old, he conveyed the two works to his sons, Paul-Antoine and Balthazar; and he died in 1739 when he was seventy years of age, leaving behind him, not only 
the credit of having founded the Strasburg fairence industry, but of being the first potter who had made true hard-paste porcelain in France.

Tery few pieces of this epoch have come down to us. We only kncw for certain of an oval-shaped salt-cellar standing on a base decorated with mouldings and gadroons, the basin being supported above this stand by four little cartouches decorated with reliefs. The paste is greyish, but the glaze is of a fine white, while the decorations are painted in pale rose-colour on the glaze. This piece is marked "H" (see Section on "Marks"). It is not known where Hannong obtained the necessary kaolin and felspar for this manufacture, but in our opinion they were derived from Passau, in Bavaria. It is not necessary here to follow up the account of the derelopment of the failence industry in the hands of the Hannongs at Strasburg and Haguenau, especially as Mr. Solon has given such an admirable account of their doings in an earlier volume of this series, ${ }^{*}$ but it is certain that Paul Hannong, the son who had succeeded to the Strasburg works, did commence the manufacture of hardpaste porcelain in real earnest about 1745 . When the old freetown of Strasburg was added to the domains of the King of France, its ancient rights and privileges had been expressly reserved to it, and Hannong considered that these privileges would protect him from the claims of the porcelain makers of Rouen, St. Cloud, or Vincennes. Realising, as a shrewd business man, the commercial advantages of hard-paste porcelain, Hannong began to recruit, about 1748, workmen from the German and Saxon porcelain factories.

The famous Ringler, who, after fleeing from Meissen, had helped to found the factory at Vienna, and Loewenfinck, who had left the factory at Höchst, both came to assist Paul Hannong with their experience and advice, and we rery soon find the factory turning out dinner-services, coffee-services, flower-pots, and small painted statuettes and groups of figures. The paste of this porcelain was very white, and not very trans-

* See "History and Description of the Old French Faïence," br MI. L. Solon. Cassell \& Co., Ltd., London, 1903. 


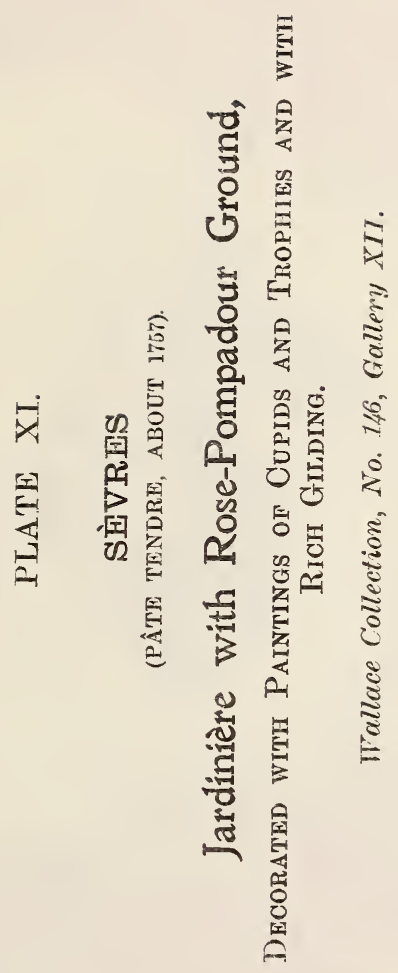





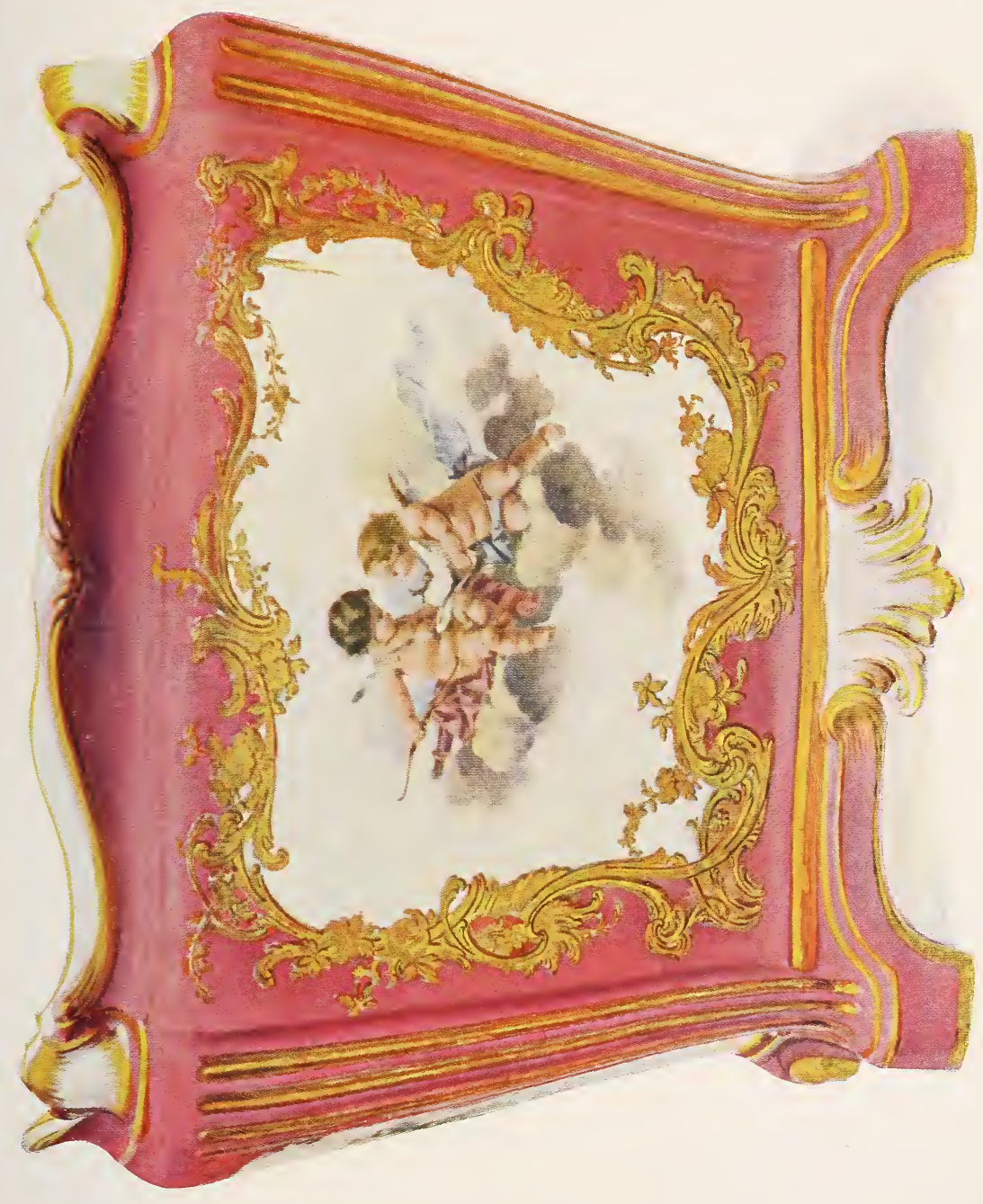



parent, while the glaze was frequently spotted or pitted, defects which were usually hidden by small painted flowers or insects, apparently displayed at random over the piece. The decoration followed the lines of that on the Strasburg faïence, being painted mostly in rose, purple and bluish-green colours, used over the glaze. The general mark was the letters "P. H.," either in cursive or capital letters, painted in blue under the glaze, or sometimes in rose or brown colour over the glaze.

Unfortunately this prosperous commencement was not to endure. The promoters of the Vincennes manufactory began to feel uneasy as to the effect which the Strasburg productions would have on their position, and sought to enforce their privilege of 1745. Hannong, knowing of this dangerous rivalry, first sought to obtain letters-patent on his own part. To this end he addressed himself to the general-superintendent, $\mathbb{M}$. de Machault, recalling the fact that for thirty years he and his father had been experimenting to perfect their processes; that at great expense he had brought the best workpeople from Saxony and other parts of Germany, and that he had accumulated great stores of the necessary raw materials. He draws attention to the quality of his productions, showing that the materials can be worked like other plastic clays, that the finished articles will resist the fire, and that the ware can receive the most beautiful decorations; while, finally, he claims for himself to have been the first inventor of hard-paste porcelain in France, and he begs to be allowed to continue the production and sale of it.

This petition produced no results, and, justly uneasy, Hannong made a visit to Paris in the hope of averting the threatening edicts. In his extremity he even appealed to Boileau, the director of the royal manufactory at Vincennes, endeavouring to treat with him for a transfer of his secrets. The records of the royal manufactory, still preserved at Sèvres, mention the purchase of a pot and a porcelain bowl from Strasburg, which were delivered to Hellot, that he might analyse the materials; while we also find that two of Hannong's workmen-a sculptor and a painter, the latter named Busch--were granted, at this time, a sum of money for their journey from Strasburg and the 
experiments they made at Tincennes. The result of these overtures was embodied in a projected agreement, which has been kept among the archives of Sèvres, and which concludes as follows:- "The particular clays and compositions which are contained in the present written agreement have been produced and communicated by me, the undersigned, according to the agreement made between M. Boileau and myself at Paris on September 1st, 1753. Signed P. A. Hannong." It appears that the management of the royal manufactory had confidence in this statement of Hannong's, but the agreement came to nothing, partly from the difficulty of obtaining the necessary materials from Passau, and partly because Hannong required in payment the sum of 100,000 livres in cash and a life annuity of 12,000 livres.

Once in possession of Hannong's secrets Boileau appears to have acted with the greatest harshness, and even spite, in pushing the persecution of Hannong to the bitter end, and he obtained a judgment in February, 1754, forbidding Hannong to prosecute his manufacture any further, and requiring him to dismantle his oven within a fortnight. The Maréchal de Noailles tried to interest the King personally in the matter, but in vain, and the utmost concession he could obtain was that Hannong might be allowed to finish the work he had in hand at the moment.

A more enlightened prince than the King of France, the Archduke Charles-Théodore, received Hannong with open arms, and from the manufactory at Frankenthal, which Hannong was able to establish by his support, have come all those charming groups, and those excellent dinner-services, which are the pride of their present possessors, and with which Sèvres has never competed, for it has never put on its porcelain a glaze or decorations analogous to these German productions.

The discoveries of this Alsatian potter, the persecutions of which he had been the object, and the success of his efforts in France and in foreign countries, were bound to make the learned men employed at Vincennes and at Sèvres more active in their researches to solve the problem of hard-paste porcelain. 


\section{PLATE XII.}

\section{SÈVRES}

(PÂTE TENDRE, ABOUT 1768).

\section{Covered Basin and Stand}

With a Turguoise Ground decorated with Paintings by Chabry.

Basin-H. $4 \frac{1}{2}$ in. W. $5 \frac{1}{16}$ in. Stand-Dia. $4 \frac{3}{4}$ in.

Victoria and Albert Museum. (Jones Bequest.) 


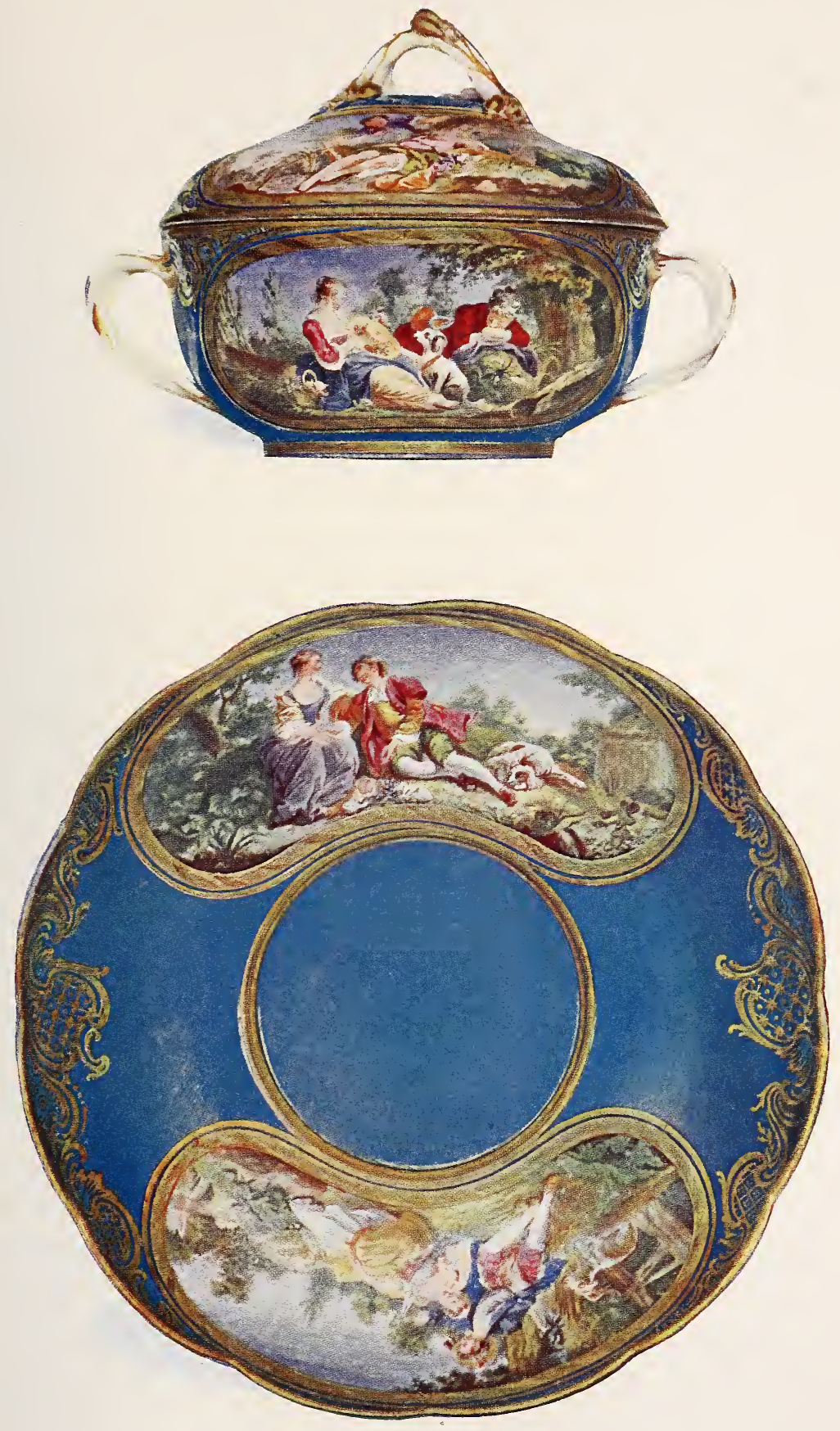

Before this time the chemist, Réaumur, had devoted much attention to the question, and though he was in full possession of the information and the materials forwarded from China in 1722 by the Jesuit, Père d'Entrecolles, he obtained no satisfactory results; while it was only in 1739 that he produced the substance known as "Réaumur's porcelain," which had nothing in common with true porcelain, but was only a species of devitrified glass.

In 1765 a chemist, named Guettard, discovered near Alençon a bed of kaolin, and claimed that from this material he had been able to manufacture hard-paste porcelain. This was true in fact, but his pieces were grey in colour, and not very transparent, and he was unsuccessful in his attempts to secure the adoption of his processes at Sèvres. In 1766 the Comte de BrancasLauraguais, a learned amateur, and Darcet, an eminent chemist, in attempting to establish some fresh points relative to the manufacture of porcelain, strove to refute, with strongly marked jealousy, Guettard's discoveries.

During this time Macquer, who assisted Hellot in his researches, studied between 1747 to 1758 , along with Beaumé, the famous physicist, an enormous number of earths, clays, and rocks of all kinds, either used alone or mixed with other substances, in an attempt to attempt to whiten the fired clays and produce hard-paste porcelain. The result of these studies will be found in the Memoir on "Clays," published in the transactions of the Academy of Sciences in 1758, which may be consulted with advantage by all who are interested in the potter's art, because it shows what can be done with any particular kind of clay in order to transform it into pottery. Certainly, Macquer must be regarded as a prophet in the potter's art for he foreshadowed the composition of faïence fine, (English earthenware) and the use of calcined bones half a century before the creation of English soft-paste porcelain.*

About 1756 two of Hannong's workmen, unwilling to retire

* This is the current French view, and so it stands as written by the author; but it is based on a misapprehension. Bones had been largely used in English porcelains at Bow and Chelsea before the date of Macquer's essay, and fine white carthenware had. long been made in Staffordshire.-ED. 
with him into the Palatinate, approached M. de Verdun, one of the shareholders of the Vincennes works, with a proposition that they should manufacture hard-paste porcelain after the German fashion. A house was rented for them at la Petite Pologne, near Paris, where they constructed two ovens, and manufactured several ovens-full of ware, but without producing porcelain. These experiments lasted for eighteen months, and cost the company some twenty thousand livres. Then two other workmen, Dubois and Chanon, who are reported to have come from Flanders, approached M. de Verdun and Boileau, and although an old château at Sèvres was fitted up for their experiments they produced nothing but a species of English earthenware.

Although it is necessary to interrupt the chronological order of events we must again revert to the Hannong family. The second Hannong died in 1760, leaving his two sons, one of whom, Pierre-Antoine Hannong, managed the works at Frankenthal, while Joseph-Adam took possession of the works at Strasburg and Haguenau, and had the sole right of disposing of the secret of porcelain in France, though in the case of its sale a third of the price paid for its sale was to be remitted to his brother. After Paul Hannong's death, new overtures were made to Joseph Hannong, but he was more mistrustful than his father had been. Boileau was sent on a mission to Strasburg and Frankenthal, and, finding that he could make no headway with Joseph Hannong, he surreptitiously approached his brother Pierre-Antoine, who was foolish enough to execute a deed before the notaries of the Châtelet, at Paris, on July 29th, 1761, in which he transferred "to the Sieur Boileau, director of the royal manufactory, duly authorised to sign this agreement, the secret of the processes of making porcelain for the sum of 6,000 livres in ready money and a yearly gratuity, or life annuity, of 3,000 livres."

Here again Boileau seems to have made a fool of Hannong, for after obtaining the document, on the ground that it was impossible to procure the necessary raw materials in France, he refused to pay Hannong the agreed sum, although the 
latter had come to Paris, and had made experiments proving the correctness of his formulæ. Finally Hannong accepted Boileau's offer of 4,000 livres in ready money and a life-annuity of 1,200 livres, which were never paid as long as Louis XV. lived. Pierre-Antoine Hannong incessantly complained of this disgraceful treatment, and finally his complaints were inquired into by the Marquis d'Angivillers who, in 1781 settled the whole affair by a payment of 18,000 livres to Hannong's creditors.

Still the management of Sèvres did not succeed with their own experiments, and after this affair of Hannong's there was the affair of Folard. In 1767 the Chevalier de Folard, an enlightened amateur, was the diplomatic agent of France at Munich. He there learned from Pfeffel, an Alsatian historian, at that time connected with the court of the Duke of Nassau, that Limprün, who was the director of a little porcelain works at Munich, knew all the secrets relating to the manufacture. The Chevalier de Folard tried to induce Limprünn to enter into the French service and take a post at Sèvres. Negotiations were entered into between M. de Choiseul and M. de Folard, who thought that by the aid of this Bavarian manufacturer, porcelain from being merely an object of luxury would soon become an article of commerce, as it was at Munich. To prove the excellence of the Munich productions a box was sent to M. de Choiseul containing two cups of this manufacture, in the inside of one of which a piece of Sèvres porcelain had been melted, while in the interior of the other half-a-dozen iron nails had been pounded. M. de Folard, in writing to M. de Choiseul states that Limpriinn possessed the whole secrets of this fabrication, both theoretically and practically; that he understood the construction of the ovens and the composition of the colours used by the painters, which he prepared himself; that he was in fact what they called in Saxony "A Universal Arcanist"; but the negotiations, which went on for some four months, came to nothing, as there was no longer any doubt in the minds of the management at Sèvres that what they wanted were the natural raw materials-kaolin and petuntse.

The chemists at Sèvres-Hellot, Millot, and Macquer-knew 
both the Chinese kaolins and the German ones, for the Elector of Saxony had even sent samples of his kaolin for their experiments. Macquer and Millot, using Saxon kaolin and kaolin from Alençon, had made a kind of porcelain, but this was not sufficiently white, and journeys to Burgundy, Champagne, and other provinces were made in search of earths which might aid in the solution of the problem.

About the end of 1765 the Archbishop of Bordeaux came to visit the manufactory at Sèvres, and after having inspected the offices, workshops and warehouses he was conducted to the laboratory, where Boileau showed him the results obtained by Macquer with Saxon kaolin, Alençon clay, and calcined alum. Acceding to the request of Boilean and Macquer, the archbishop agreed to take samples of the kaolin to see if any analogous substance might be found in the neighbourhood of Bordeaux. On returning to his diocese the archbishop showed this clay to an apothecary, Villaris, who had travelled a good deal, and was well acquainted with all that part of the country. Villaris visited the Pyrenees and the Cévennes, but unsuccessfully, and quite discouraged by his want of success, he happened to show a sample of the kaolin he was in search of to the Sieur Darnet, of St. Yrieix. To his profound astonishment this material was immediately recognised by Darnet, whose wife had for some time been in the habit of using as a washing material a white clay of a similar kind, which was found on the surface of the soil at St. Yrieix, and Villaris obtained about three pounds of this clay, which he despatched to the directors of the manufactory at Sèvres.

In the Museum of Sèvres there is preserved a little statuette of Bacchus, in white glazed hard-paste porcelain, made from this clay, which is rightfully described as being the first piece of true porcelain manufactured at Sèvres. But their difficulties were not yet at an end, as Villaris refused to divulge the source from which the clay had been obtained, expecting to obtain a large sum of money for his chance discovery. Irritated by this unexpected difficulty, Boileau obtained from the minister Bertin permission to despatch Millot and Macquer in search of the 


\section{PLATE XIII.}

\section{SÈVRES}

(PÂTE TENDRE, ABOUT 1757).

Covered Vase (Vase calice)

With Grounds of Bleu-de-roi and Apple-green, decorated with a Camp-scene and with carhful Painting and Gilding. The piece is signed by Falot, but the Painting of the CaupSCENE IS ATTRIBUTED TO MORIN.

Wallace Collection, No. 159, Gallery XVIII. 



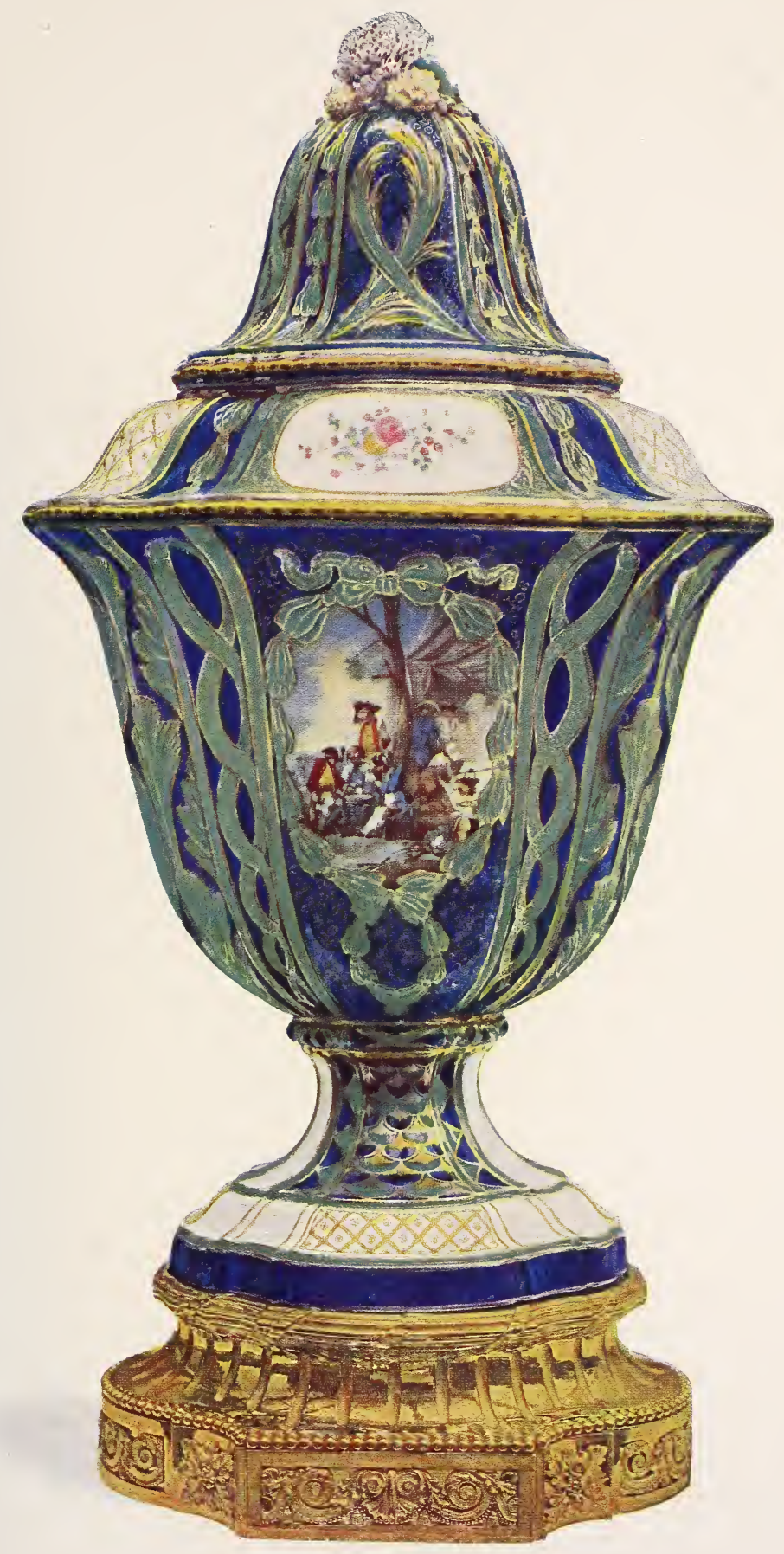



kaolin, and we must quote their account of the journey. "When we arrived at Bordeaux we went directly to Monseigneur the Archbishop to present our compliments, and were received with great kindness. The next morning Villaris came to us at our inn, but would not tell us where this clay was to be found, saying that the minister might not reward him for his trouble. We therefore wrote to M. de Bertin, but after waiting nine days for an answer, his letter, when it arrived, forbade us to hold any more converse with Villaris, and directed us to search in the neighbourhood of Bordeaux, and even as far as Bayonne. We stayed there for eight days, and two days at Biarritz, without finding anyone who could tell us of a clay similar to our samples. From Bayonne we came back to Dax, where we stayed twenty-seven days, searching in every direction in the neighbourhood. Near Pouillion we found a species of white earth resembling chalk, and very refractory. I brought several pounds of this to Dax, and after washing it carefully I made it up with other materials into several little placques which I had fired in the forge of a locksmith named Sainte-Marie. These first little slabs were somewhat smoked because of the poor quality of the crucibles, and we then had recourse to M. Bordat, president of the town, to ask him whether, being a naturalist, he knew of any material for making crucibles to resist a high temperature. As he could find nothing in his natural history collection I used the white earth which I had found near Pouillion to make crucibles. The next day I went for a walk nearly all day long without finding any good clay. I only found a kind of plaster-stone which I brought to our inn, where I broke it into pieces and put it for half an hour in the fireplace with lighted coal. Afterwards I pounded it well and passed it through a sieve, which gave me very good plaster. With this I moulded the half of an egg to serve as a mould for my trials. With this I made some small cups and several small slabs, which I again fired at our locksmith's, and in these experiments I was more successful than the first time, so that, after all our little trials had been made, we returned to Bordeaux with about forty pounds of perfectly decomposed clay and the little 
experiments in porcelain made at Dax. When the archbishop had examined our samples he sent for Villaris, who was much perplexed to see that in spite of his refusal to assist us we had found a kaolin as well as himself.

"The next morning the Sieur Villaris came to visit us again, and he was not so proud as when we first came to Bordeaux, and now offered his assistance and promised to take us to the place where the kaolin was, saying that the minister could please himself how he rewarded him for his trouble. On the appointed day he was to wait for us at Tiriée (St. Yrieix) in Perigord. The next day we went to join Villaris at Tiriée, and lodged at the house of one Dubourg, an innkeeper and land surveyor. Villaris had chosen a house for us as far as possible from that of M. Darnet, the surgeon of this town, that he might not be seen by him, although they were friends and it was Darnet who had given Villaris the first samples of kaolin. Our shortest way would have been to go through the town, but as this would have led us past M. Darnet's door, Villaris made us go through all the gardens on the outskirts of the town to reach the kaolin, which we found beside the churchyard of the parish, in a little path so dark that it was almost impossible to see.

"While we were digging the kaolin two men passed by, and on perceiving what we were about they ran to tell Madame $\mathrm{du}$ Montait, the owner of the land. She sent her son to us at once to ask by whose permission we took her soil, and to tell us that if we did not leave off he would raise the hueand-cry after us, and bring the people together to stop us. On this we left off directly, and M. Macquer sought the mayor of the town and communicated to him the orders we had received from the minister to search for clays suitable for the manufacture of porcelain for the King. We obtained a tun full, of about four hundred pounds, taking that which was the whitest, and this we had passed through the Custom House at limoges in order that it might be transported to Sèvres."

When the travellers got back to Sèvres they were able to manufacture hard-paste porcelain with success, and in a com- 


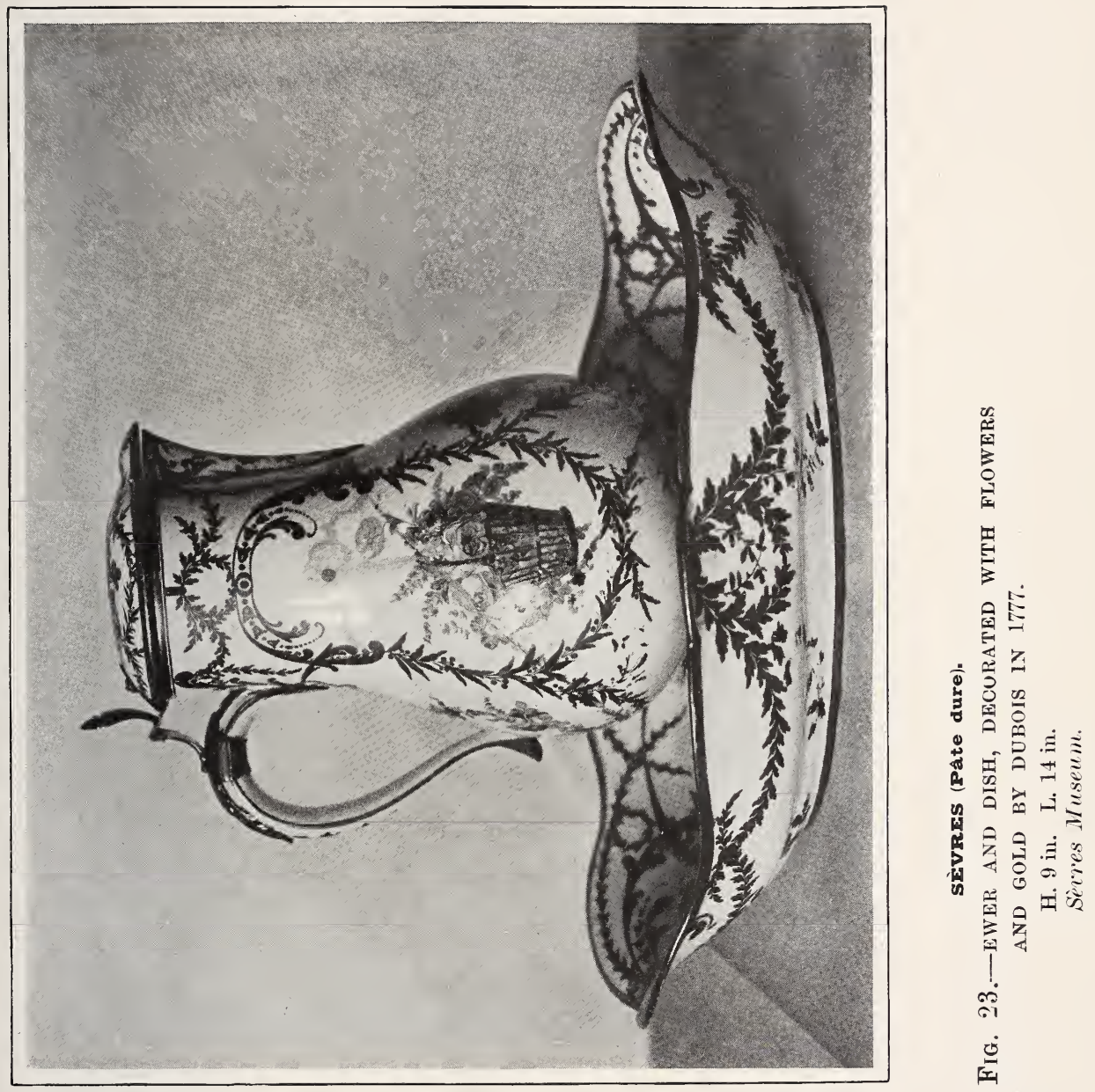



munication to the Academy of Sciences in June, 1769, Macquer describes the St. Yrieix kaolins and their special qualities, and explains, without entering into technical details, the manufacture of this new porcelain. All that was needed now was the royal approval, and Macquer gives us a rather amusing account of the scene. "On St. Thomas' Day," at eight o'clock in the morning, I went with M. de Montigny to Versailles. At 11.30, M. Bertin, who had gone into the King, sent for us to take us into the rooms where the porcelains from Sèvres were exhibited as usual, and where on a special table was the new porcelain all in white and gold. There were about sixty pieces, all of them very beautiful. As we were examining them the King came in alone. He received us very graciously, and, without stopping to look at the old porcelains, he went straight to examine the new, with which he seemed very much pleased. Three coffee-pots of our new porcelain had been put before a large fire. The King asked us several questions, and told us how, a little while ago, he had had a little experience with a cooking-pot of M. de Laborde's porcelain, which, being put over a spirit-lamp, in order to boil some water, was immediately broken. $\mathrm{He}$ inferred from this that the spirit-lamp was more dangerous to the porcelain than a coal-fire. At this moment the water began to boil in a little cooking-pot of our new porcelain which had been placed on a spirit-lamp, but an instant afterwards this pot also broke in the presence of His Majesty, who burst out laughing, going backwards and saying, 'Sir! Sir!' after which he went to mass, at which we were also present."

Macquer was disappointed at this misadventure, but in the evening he repeated the same experiment successfully, and received the compliments of the King in the presence of the court.

The reign of hard-paste porcelain was about to commence.

* 21st December, 1739. 


\section{CHAPTER X.}

THE LAST MANUFACTORIES OF SOFT-PASTE PORCELAIN: SCEAUX, BOURG-LA-REINE, ORLÉANS, TOURNAY, ARRAS, ST. ANAND.

IT seems astonishing that the strict monopoly granted to Vincennes did not entirely end all the small rival factories, but some few survived, partly by evading the edicts, but chiefly by the production of very cheap porcelains. In addition to the factories already mentioned there were some of lesser importance whose doings must be briefly sketched.

\section{SCEAUX.}

Jacques Chapelle, one of the "universal geniuses" of the period, who had pretensions as artist, sculptor, chemist and physicist, settled about 1748 at the faience works of Sceaux belonging to an architect, De Bey. Chapelle had been a great traveller, and in the course of his wanderings had acquired a knowledge of porcelain-making. In some autobiographical writings he tells us that he had founded in Paris a manufacture of porcelain as perfect as that of Saxony, the quality of which was highly esteemed both by dealers and connoisseurs.

A company was founded at Sceaux, Chapelle having undertaken to obtain, through the patronage of the Duchesse du Maine, a royal privilege for the manufacture of porcelain. By 1749 a commodious factory had been arranged, a staff of workpeople engaged, and all was ready to commence operations. Chapelle, however, had not reckoned sufficiently on the privileges already granted to Charles Adam at Vincennes (see p. 42); and his patroness, the Duchesse du Maine, was not powerful enough 


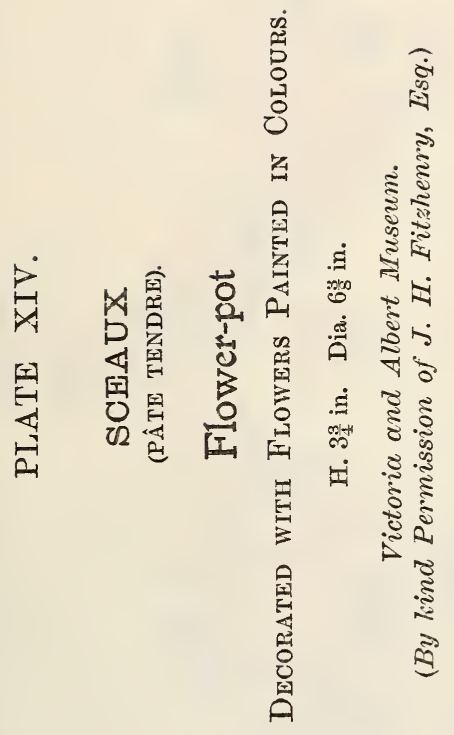





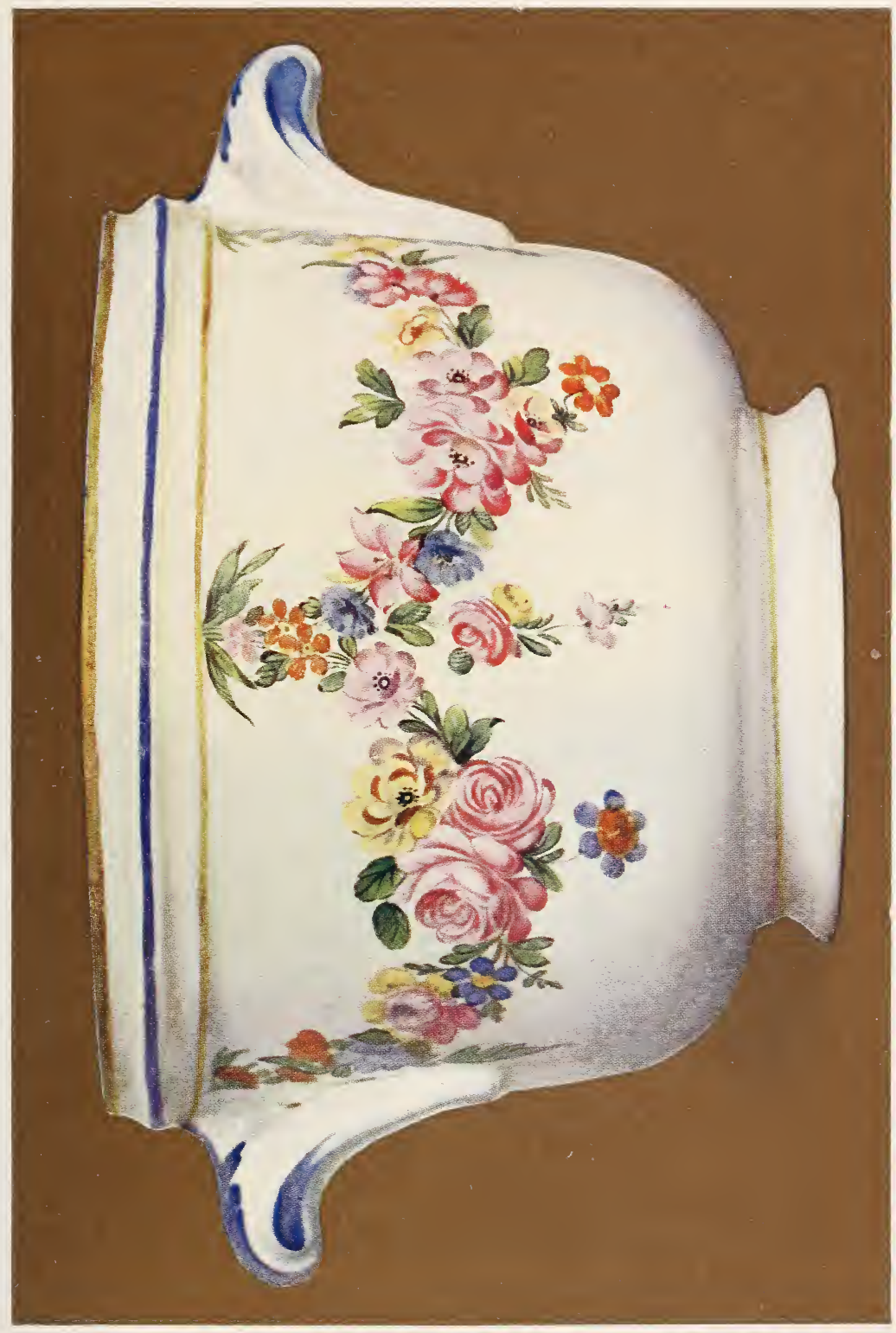



to resist the authority of Madame de Pompadour, so that the company was compelled to abandon its intentions and to content itself with the manufacture of a variety of faïence, which they called Faïence Japonnée. The business was acquired in 1763 by Jullien, one of the best painters, and Jacques, a Parisian sculptor; Jullien being fully informed as to Chapelle's porcelain. In 1772 Richard Glot succeeded to Jacques and Jullien, who had taken over the porcelain works at Mennecy-Villeroy" (see p. 35), and who founded the works at Bourg-la-Reine.

In 1775 the works secured the patronage of the Duc de Penthièvre, High Admiral of France, and under his powerful protection they again produced porcelain without fear of prosecution, though it was not until 1784 that they obtained permission to use painting in varied colours and gilding, by the modification of the monopoly of Sèvres. In spite of this fact there is no doubt that porcelain had been made by Jacques and Jullien, and the paste and glaze are in every respect similar to thuse of Mennecy, the borders and rims being lined with rose-colour during the whole period when gilding was forbidden. The flower paintings, and the designs of exotic birds are generally sweeter and better designed than those of Nennecy. The "seau" (ice-pail) from the Victoria and Albert Museum, reproduced in Plate XIV., is very typical of the style of flower painting in use at this factory. The mark consists generally of the letters "S.X." inscribed in the paste; but many beautiful pieces, especially vases and groups, which it is impossible to attribute to any other factory, bear no mark.*

\section{BOURG-LA-REINE.}

In 1774 MM. Jacques and Jullien founded at Bourg-laReine, a little place near Sceaux, a manufactory of soft-paste porcelain under the protection of the Comte d'Eu, it is said after' the expiration of their lease at Mennecy-Villeroy (see p. 35). It is, therefore, only natural that the products were so like those of the latter factory that, in the absence of marks, it is difficult to

* An interesting account of the faïence of Sceaux will be found in Mr. Solon's "History and Description of Old French Faïence." Cassell \& Co., London, 1903. 
distinguish between them. There must have been a considerable demand among the people living in the environs of Paris for porcelain in the Mennecy style, seeing how persistently those shapes and decorations were reproduced. We represent in Plate XV. a characteristic piece of this class, in the form of a sugar-dish, with cover and stand, preserved in the Victoria and Albert Museum.

The factory was continued to the Revolution, for in 1788 we find the son of Jacques, one of the founders, who had become a director of the company, lodging strong complaints with the Minister of Commerce as to the harm done to this business by the importation of English pottery, rendered possible by the recent commercial treaty. He also revived these complaints during the revolutionary period.

The mark of Bourg-la-Reine consists of the letters "B. R." inscribed in the paste. It should be added that the edges and rims of the pieces are almost invariably lined with rose-colour; we know very few that are gilded.

\section{ORLÉANS.}

In 1753, Sieur Gerréault established at Orléans, under the patronage of the Duc de Penthièvre, a porcelain manufactory, for which he was able to obtain the authorisation of the Council of State. Soft-paste porcelain was made until 1770, after which hard-paste porcelain only was manufactured.

This Orléans soft-paste was extremely vitreous and translucent, while the glaze was also exceedingly brilliant. The pieces were well made, all the mouldings and reliefs being skilfully modelled and sharply cut. The pieces comprised some few statuettes, but table services were more common, and were generally decorated with detached flowers painted in underglaze blue, or more frequently with painted bouquets touched up with gold.

The mark is a label with the letter " $\mathrm{C}$ " below (see Section on "Marks"). Although a considerable quantity of the softpaste porcelain of Orléans must have been made during the 


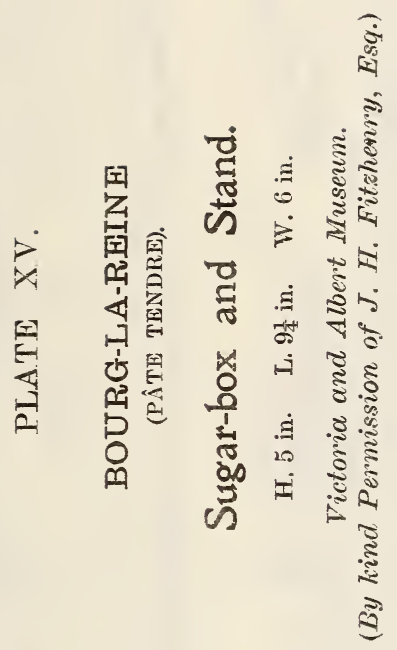





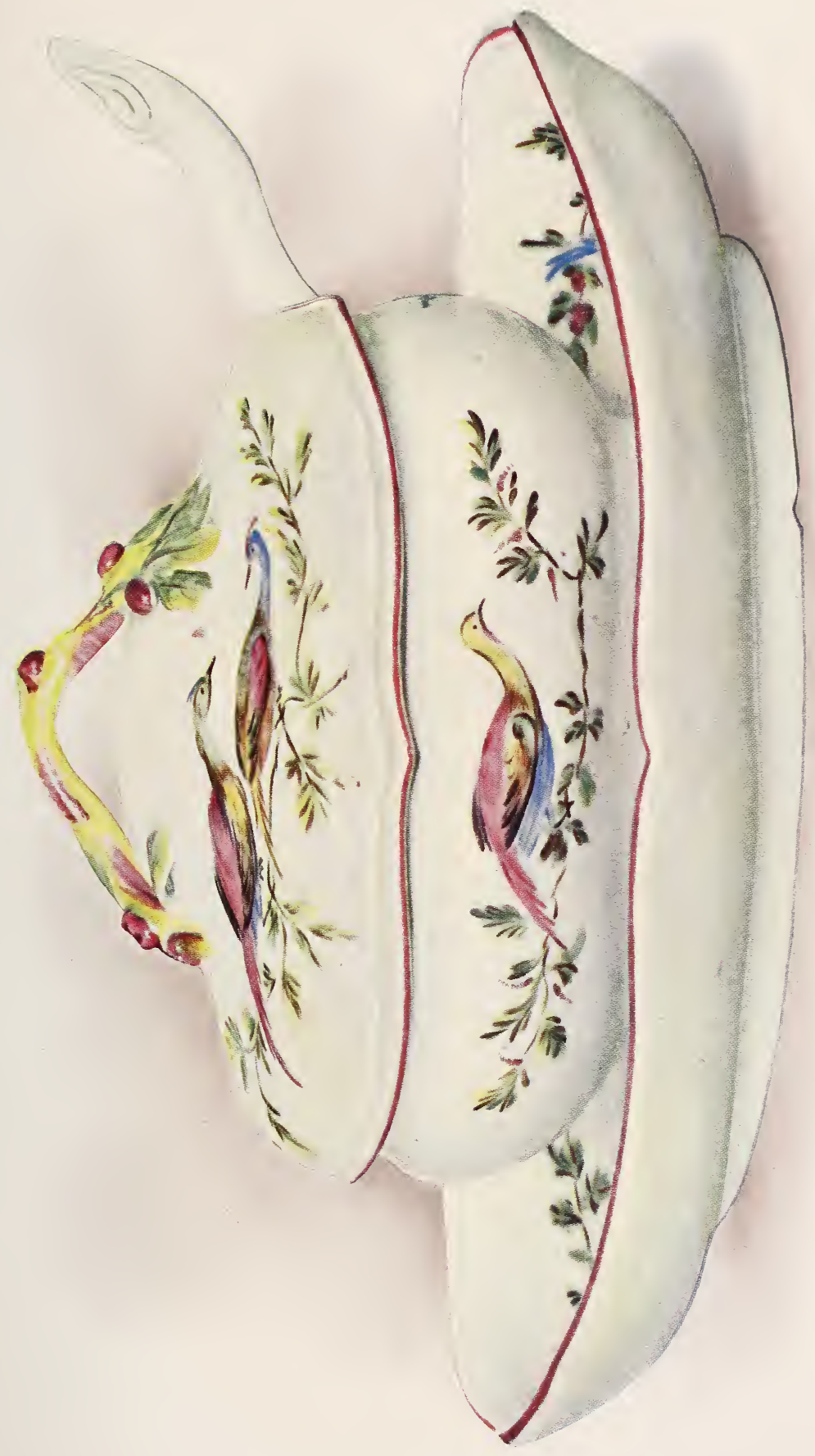



seventeen years of the existence of this factory, pieces are now very rare, a fact that we can only attribute to the extreme fragility of such a vitreous paste.

\section{TOURNAY.}

We have considered it right to include Tournay among the French factories, as during the time when its porcelain was famous it was under the dominion of the French crown. The first soft-paste porcelain was made here by Peterinck, in 1750, and the business was so successful that in 1762, two hundred and fifty workpeople were employed. About this date the manufacture was greatly improved by a chemist named Dubois, and as his methods differed somewhat from those employed at Vincennes (see pp. 46, 47) we give a brief account of them.

The frit for the paste was made by fusing together sand and soda of Alicante.* This frit was made into a working paste by mixing it with a clay marl and pure chalk. A great number of the pieces were thrown or moulded, but it appears to have been at Tournay that the process of "casting" was first applied to the manufacture of porcelain. $\dagger$ In this process the slip (a fluid mixture of the porcelain paste and water) is poured into moulds of plaster of Paris. The plaster absorbs some of the water from the slip and the mould thus becomes coated on the inside with a layer of paste, the thickness of which is dependent upon the time during which the mould remains filled.

The ovens were fired with wood for a period of only fifteen or sixteen hours, or about one-fifth the time occupied at Vincennes or Sèvres.

There appear to have been two classes of production at Tournay, one for the finest, and one for the commoner pieces. The paste of the former is not so yellow in tone as that of Chantilly or Mennecy, though it is not so white as that of Sèvres, whilst it also seems more porous in structure. The

$$
\text { -ED. }
$$

* The common name for the very impure carbonate of soda used at this period.

$\uparrow$ The process of "casting" appears to have been used in the manufacture of the Staffordshire salt-glaze even earlier. See Burton's "History of English Earthenware and Stoneware." Cassell \& Co., Ltd., London, 1904.-ED. 
glaze is as perfect as one could desire. The pieces of this superior quality were modelled on the shapes of Dresden, or of China, while the decorations were finely executed, and among the colours used, a fine red, obtained from oxide of iron, is noteworthy.

Subsequently, the influence of Sèvres became predominant, and we find the ribbon decorations, the grounds of ail-deperdrix, the paintings of exotic birds and little landscapes forming the chief decorative feature of Tournay porcelain. We reproduce in Figs. 24 and 25 a cream-jug and a covered sugarbasin of this period, decorated with paintings of cupids en camaïeu in a purplish-rose colour, relieved with gilding artistically arranged. At this period, too, the ground colours of Sèvres, notably the bleu de roi, were also successfully reproduced. We may mention as showing the fine quality of the Tournay pieces of the superior kind, that white pieces have often been subsequently decorated in the Sèvres manner and palmed off with a false Sèvres mark as the genuine productions of that factory.

The more common kind of porcelain made at Tournay was very thick in substance, and nearly opaque. It was generally painted in blue, with little sprays or garlands, and the dishes and plates of this manufacture were greatly appreciated by innkeepers and others, because of their strength and durability. This kind of Tournay porcelain is still manufactured, and all such pieces generally bear only letters indicative of the pattern, or workmen's marks.

The fine Tournay porcelains were marked in gold, or in onglaze colours, with two crossed swords and with four crosses. (See "Section on Marks.")

ARRAS.

Although there is in Dr. Warmont's collection a plate bearing the date 1711, which is supposed to have been made at Arras, we know nothing of any manufacture of porcelain at that period. We only know that in 1782, M. de Calonne, Governor of Flanders and Artois, observing with a jealous eye the progress 


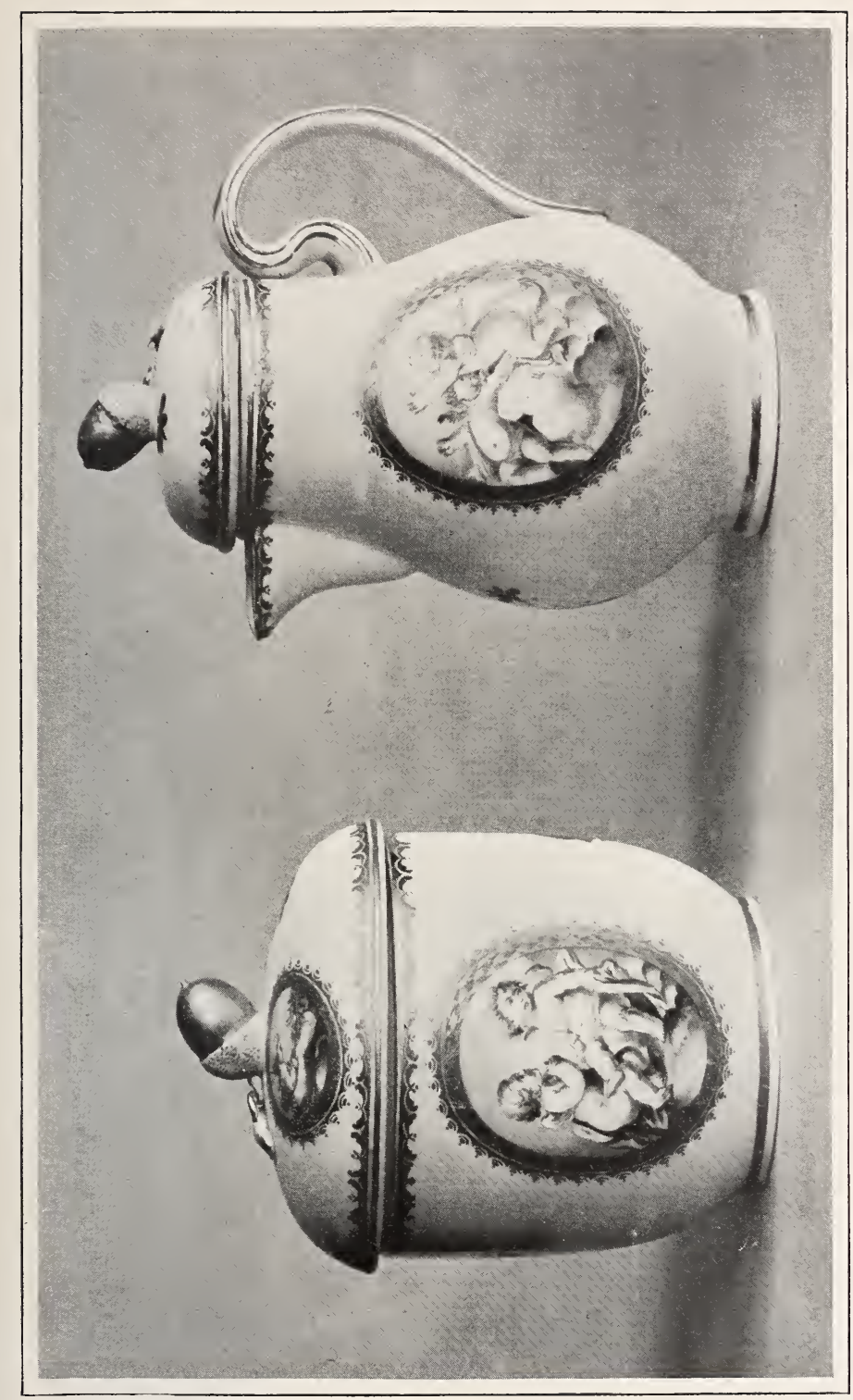

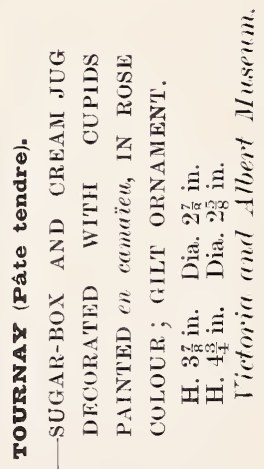

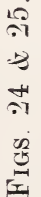



of the works at Tournay, and seeing his district overrun with porcelain from Worcester, encouraged two ladies named Deleneur, who were faience-dealers in Arras, to commence the manufacture of porcelain, for which he undertook to provide funds. This works only existed for some five or six years. The porcelain was of a yellowish-white paste, more like that of Mennecy than of Tournay, and was generally decorated in blue only. But the Tournay productions were too cheap and too well-liked to enable the works at Arras to attain any real success, and the enterprise soon came to an end.

The mark is "A. R." in under-glaze blue; and sometimes an initial of the painter is added to the factory mark.

\section{SAINT-AMAND-LES-EAUX.}

A faïence manufactory was established here in the eighteenth century by a potter named Fauquez who came from Tournay.* After the Revolution the works was continued as a factory of faïence fine (earthenware), and about 1815 the making of softpaste porcelain was undertaken by Dorchies Herbo when Tournay was separated from France. We only mention the factory because it, along with Tournay, has continued the production of soft-paste porcelain to the present time. The fine white of this factory has been frequently used by forgers as the basis of numerous imitations of Sèvres pieces. It has in addition produced vast quantities of cornmon porcelain decorated in underglaze blue.

* See M. L. Solon's “ Old French Faïence," p. 83. Cassell \& Co., 1903. 


\section{CHAPTER XI. \\ SÈVRES FROM 1769 TO 1774.}

Madame de Ponpadour died in 1764, but it was not before 1770 that the reign of Madame Dubarry commenced, and this was of short duration owing to the death of Louis XV. in 1774. The influence of Madame Dubarry on the artistic fate of Sèvres was certainly much less than that of Madame de Pompadour, but it should be said that she always appreciated things that were of matchless richness, and she remained one of the most faithful patrons of the factory at Sèvres.

The hard-paste porcelain which had been just invented in 1769 , received all the attention of the chemists of the establishment. The paste was composed of kaolin and sand, to which a little chalk was also added, whilst the glaze consisted of quartz or sand, chalk, and fragments of broken porcelain, ground to an impalpable powder. This glaze was not nearly so glossy as that of the soft-paste porcelain; indeed, it was relatively opaque, so that the early hard-paste porcelain of Sèvres has a very characteristic whiteness. Naturally the colours used on the soft-paste porcelain, which incorporated themselves so easily and so perfectly with the glaze, had to be modified to suit the new materials. Special colours and grounds were gradually developed for this purpose during the reign of Louis XVI., but we will refer to these in a subsequent chapter.

By force of circumstances the two manufactures went on side by side during the period under review. The soft-paste porcelain was peerless from the point of view of the painter, and, although it did not permit the making of large vases and monumental 


\section{PLATE XVI.}

\section{SḦVRES}

(PÂte TENDRE, ABOUT 17̈68).

Bottle-shaped Vase (Vase bouteille).

Ground of Vert Fonce, decorated with Rich Gilding; the Panels are decorated with Mythological Subjects and Eniblems; GILDING BY VINCENT Ṗ̀RE.

Wallace Collection, No. 152, Gallery XII. 



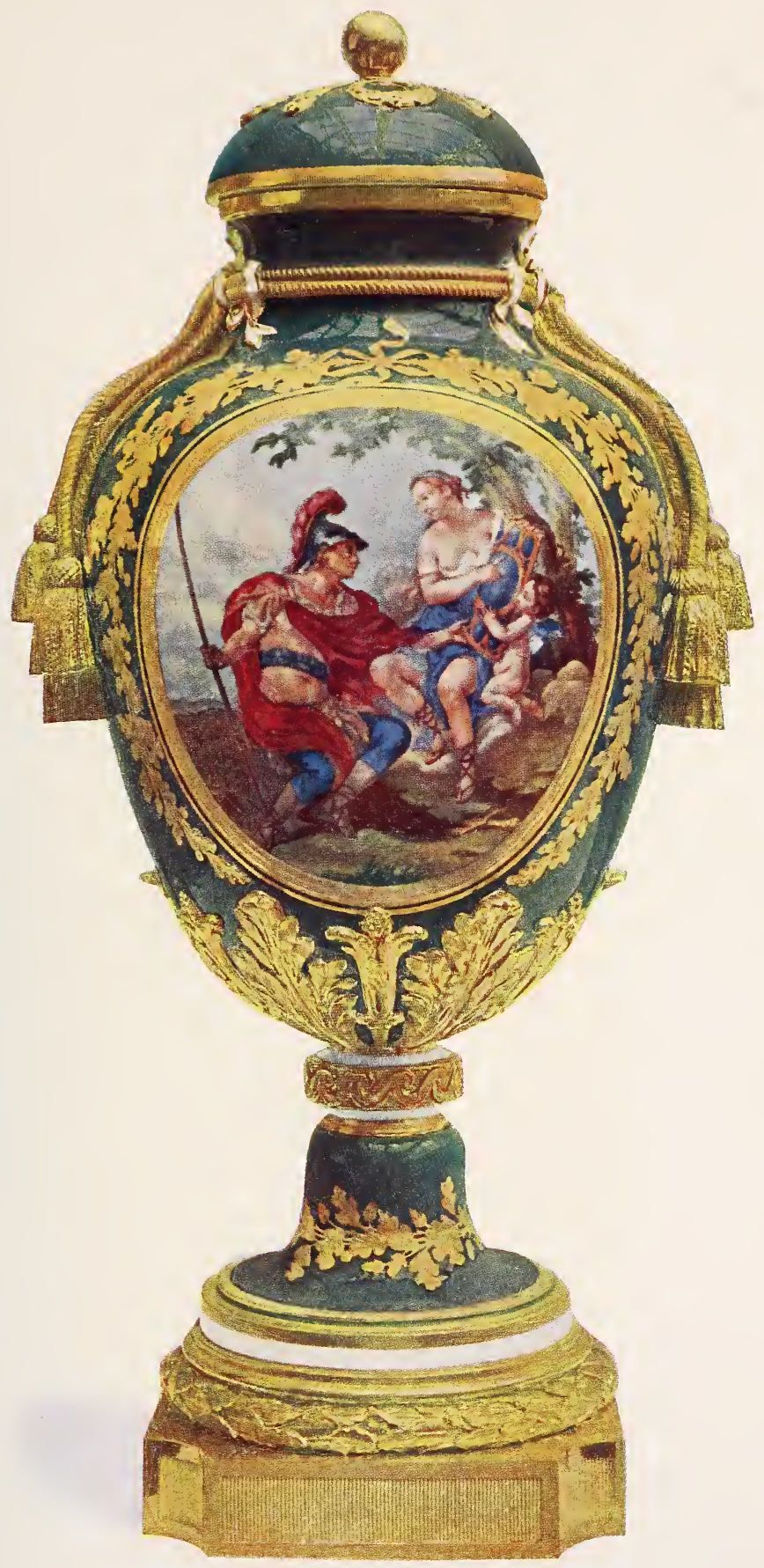



pieces such as were made in Saxony or in China, in capable hands it lent itself to the production of excellent shapes and forms. The sculptors of this period were as before-Duplessis, Falconet, La Rue, Bachelier, Bolvry, and Le Riche, who produced all the models of the pure Louis XV. style, in which rocaille ornament prevailed. The plates are festooned, or moulded with ornamental details of great fineness, while the handles of cups and other vessels were most delicately chiselled.

As to the vases, a most important feature of the productions of the period, we have taken the names of the most famous and characteristic from the moulds or models of the Sèvres manufactory. A vase often made in this period, though it had been modelled by Duplessis before this time, is that known as vase à anse tête d'éléphant; then there is the vase Oglio of a very complicated design in the rocaille style, formed in the shape of foliage and scrolls intermixed; the vase tulipe it oreilles, perfect specimens of which are in the Wallace Collection; vase militaire, ornamented with flags and trophies; vase ovale c̀ têtes de bouc, of great elegance; vase aux tritons, a vase supported by tritons modelled by the sculptor La Rue; and a vase in the shape of a basket known as vase ruche d'abeilles.

A great number of vases have twisted or straight sides of great purity of line, and of these we may mention a vase known as vase tête de bouc Dubarry, while another, the "vase Paris," was, perhaps, the largest ever made in soft-paste porcelain, being about thirty inches high. We may also mention the vase $\dot{c}$ oignons, pierced with holes so that it might be used for cultivating Dutch bulbs, one of the fads of the moment, and the vase à l'Amour Falconet, which is terminated by the shaft of a column bearing a statuette by the celebrated sculptor above the inscription :

"Qui que tu sois, voici ton maître.

Il l'est, le fut, ou le doit être!"

On other vases ships' cordage served to frame oval medallions, while a vase called rase antique ferré bore the 
representation of an iron foundry, this being the same vase on which we find the oval medallions bearing scenes from the Battle of Fontenoy (see p. 67); another, vase tête de bouc à raisins bears handles formed of a goat's head entwined with vine branches with grapes, arranged with very great skill. We have already mentioned in a previous chapter the famous vaisseau à mât, let us also point out from the year of the Comet, 1769 , the vase Comète, in the form of a sphere on a low pedestal.

The Wallace Collection contains many choice examples of the vases of this period; here, besides most of those mentioned above, we find the vase fontaine aux dauphins, the vase bouteille, the vase pot-pourri, the vase à camées, the vase ì quatre cartels, etc. Some of the most interesting of these shapes will be found reproduced in this volume.

The jardinières of this period are also perfect in form, and we illustrate in Plates VII. and XI. and Figs. 19 and 22 examples which show, not only the purity of line of the designs, but how perfectly adapted they were to their purpose.

A certain number of ornamental clocks were also produced. In some of these bronze plays the more important part, the porcelain only being accessory, while others, in which the porcelain parts are of the greater importance, will be mentioned in the section dealing with Sèvres "biscuits."

After the death of Madame de Pompadour the King still remained interested in the success of Sèvres. In order to stimulate the zeal of the artists, and augment the sales of the porcelain, exhibitions were arranged in the Palace of Versailles at the end of every year, and the King attended the exhibitions and took the greatest interest in the sales. Let us quote from a contemporary account :-

"Every New Year's Day they bring into the galleries at Versailles the newest and choicest pieces of Sèrres porcelain, which the King himself distributes among his great lords for their money; he fixes the prices himself and they are not cheap. We presume that the prices must be pretty high on account of the financial situation, but we shall speak about that later on. It is certain that some of the noble lords are not ashamed of 


\section{PLATE XVII.}

\section{SEेVRES}

(PÂTE TENDRE, ABOUT 17i5).

\section{Vase and Cover (Vase à quatre Cartels).}

With Bleu-de-roi and Gold GiL-De-Perdrix Ground. The Panels decorated with Paintings of Marjane Subjects and Flowers by Morin and Boulanger; the Gilding by Cunaveau père.

Wallace Collection, No. 21, Gallery XVII. 



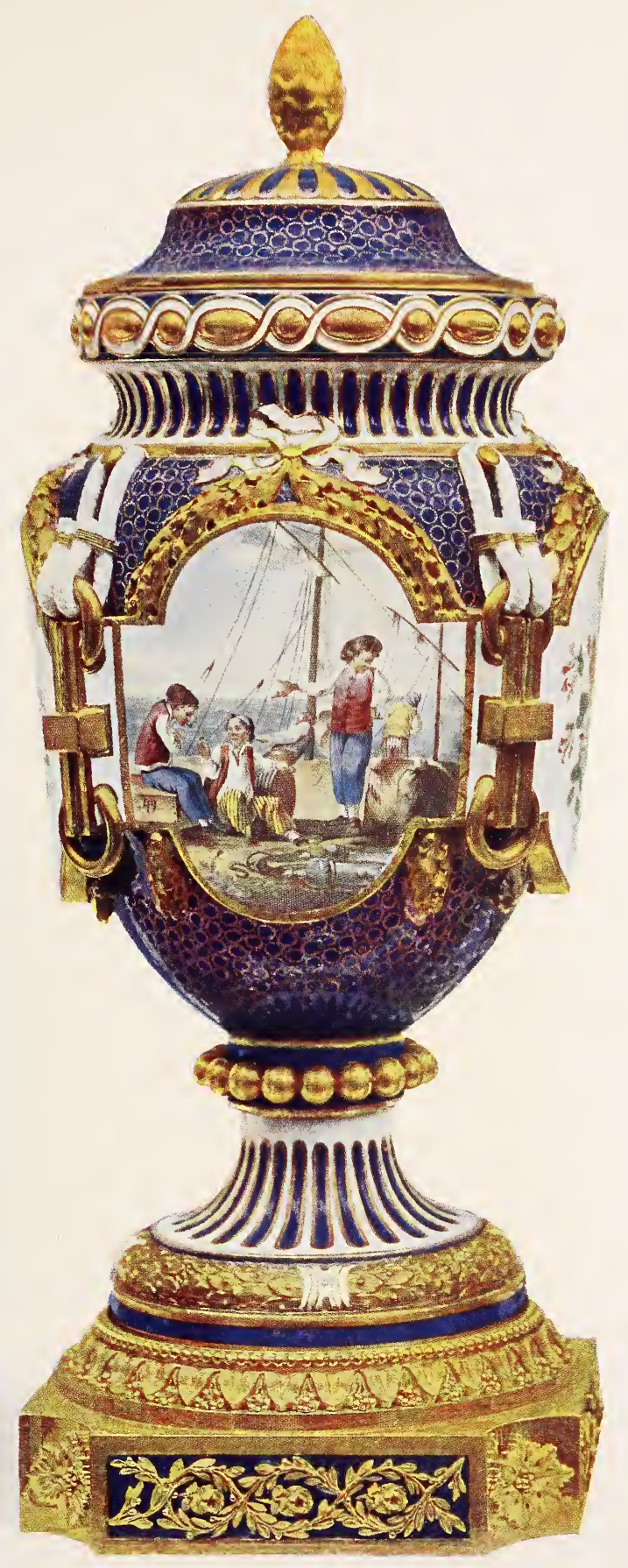



taking a cup, or some little ornament, when they think they are not observed. Seeing a count take a cup in this way, Louis XV. sent to him next morning the cashier from Sèvres with the saucer that he had been unable to take, and a bill for the pieces. One day the King saw that an abbé refused to purchase a piece on account of its price, but in order to persuade him the King immediately promised him a benefice."

One of the most remarkable services of this period is preserved in the Rosenburg Museum at Copenhagen. In 1768 the King of Denmark visited Sèvres with Louis XV. who presented him with this table service with a lapis-lazuli ground. This service of one hundred and eighty pieces, cost, according to the registers, about 33,000 livres (£1,320). The lapis-lazuli ground (lapis caillouté) was formed of a deep bleu de roi ground, the inequalities of which were veined with gold lines in imitation of the lines of pyrites found in the natural stone.

In speaking of the forms of the vases, we have given the names of the sculptors. The painters were legion. The decorations in the Chinese style, which we describe to-day as Chinois Louis $X V$., were executed by Le Guay, Drand and Lecot. Animals and birds were painted by Dodin, Aloncle, Armand (the younger), Chapuis (the elder), Evans and Falot. Flowers were painted by Aubert, Armand (the younger), Barrat, Bouillat, Bulidon, Buteux (father and son), Chapuis (the younger), Commelin, Cornaille, La Roche, Le Bel (the elder), Mérault (the younger), Micaud, Niquet, Noël, Pierre, Sioux, Taillandier, Tandart and Tardy. Miniatures and pastoral subjects are generally signed Asselin, Chabry, or Pithou (the younger). Landscapes and subjects en camaïeu were treated by Bouchet, Bouillat, Evans and Rosset. Ornaments and emblems were confided to Chulot, Falot, Mérault (the elder) and Vieillard. Sea pieces and military subjects were the work of Morin and Pithou (the elder); while the gilders were Le Guay, Beaudoin, Prévost, Chauvaux and Vincent.*

* The most complete list of the painters and decorators employed at Vincennes and Sèvres from 1750 to 1900 will be found in the recently issued official "Guide du Musée Céramique de Sèvres," by Mr. G. Papillon. Paris, Ernest Leroux, 1904._ED. 
Apart from the exhibitions at Versailles on each New Year's Day, the sale depôt at Paris, in rue de la Monnaie, was maintained. All the dealers in antiques and curiosities also sold porcelain, some of them, such as Duluc, Poirier, and Madame Lair, selling as much as 80,000 livres' worth each.

The early pieces of Sèvres porcelain were eagerly collected by the connoisseurs of the day, as we learn from the Journal of Lazare Duvaux. The chief collectors of the period were the Duc d'Aumont, the Marquis d'Argenson, and the Princesse de Talmont.

This was the epoch, too, when the first pieces of furniture decorated with porcelain made their appearance, but we shall study this branch of the subject in connection with the period of Louis XVI., when the rich and carefully executed furniture, now so highly prized by collectors, was also produced.

From 1769 to 1774 the date letters from "R." to "V." were placed between the interlaced " L's." 


\section{CHAPTER XII.}

SÈVRES UNDER LOUIS XVI., 1774-1789.

IT would not be quite correct to say that the golden period of Sèvres came to an end with the death of Louis $X V$., but a change soon followed that event. Just as the French kingship passed into feebler hands, so we find Sèvres, under Louis XVI., becoming, after a few years, a very different Sèvres from that of Louis XV. This change was, perhaps, more pronounced because of the death of Boileau, which soon followed that of his royal master. Whatever we may think of Boileau's conduct with regard to Hannong, and there seems little doubt that he treated that unfortunate potter with harshness and injustice, it will always be to his honour that he was the director during the most glorious period of the works; that he knew how to interest the King in its progress, as well as how to unite the rival ambitions of the chemists, sculptors, painters, and workmen of the establishment.

We have seen that the works at Sèvres owed much to the patronage of Madame de Pompadour and, in a lesser degree, to that of Madame Dubarry. During the present period the influence which had been exercised by the mistresses of the late King was to be exercised by one of the most famous of Queens, MarieAntoinette. This Princess, almost immediately after her marriage, was conducted over the works at Sèvres, which was just then engaged on the manufacture of the most sumptuous "garnitures" for the palace of Louveciennes, and on the production in "biscuit" of the famous bust of Madame Dubarry, modelled by Pajou. Although Marie-Antoinette was immediately 
interested in the productions of the factory, she had no direct influence upon it until after her coronation in 1774. Yet she soon became a patroness of Sèvres for, from 1771 to 1774, part of the personnel was employed in making, for her, furniture and garnitures of all kinds analogous to, or identical with, those which had been made for the Dubarry. The director of the works, who was a good courtier, had already produced in 1772 a "biscuit" group, modelled by Pajou, and called "The Marriage of Louis XVI." In this group the Dauphin is on the left, the Dauphiness on the right, clasping their hands on a kind of altar surmounted by a globe ornamented with "fleurs-de-lys." The front of the altar had the inscription "Au bonheur public" while the pedestal bore, in low relief, garlands of flowers, and a royal monogram composed of the initials "L." and "A." intertwined.

About 1773, the sculptor Pajou made a bust of MarieAntoinette in which, while we cannot but admire the regal attitude of the daughter of an empress and the wife of a mighty prince, we are still more charmed by the juvenile freshness and grace of the woman, the beauty of her features, and the arrangement of her hair. In this model Pajou certainly produced one of the finest works of the eighteenth century, and it seems like the irony of fate that it can only be compared with the busts of the Dubarry produced by the same sculptor. In the Petit Trianon an example of this bust, doubtless made at this very period-broken during the Revolution, but restored in our own time-is carefully preserved; while another example, made several years later, is now in the palace of Versailles. Marie-Antoinette was not unacquainted with the manufacture of porcelain, for her mother, the Empress Maria-Theresa had displayed the greatest interest in the productions of the porcelain works at Vienna. The Viennese porcelain of that epoch, was, however, heavily and elaborately decorated with a profusion of coloured grounds, painted subjects and ornaments, and much gilding, all of which served to conceal the imperfection of the material itself. Marie-Antoinette seems to have preferred the white porcelain of Sèvres, much more simply decorated, and she 


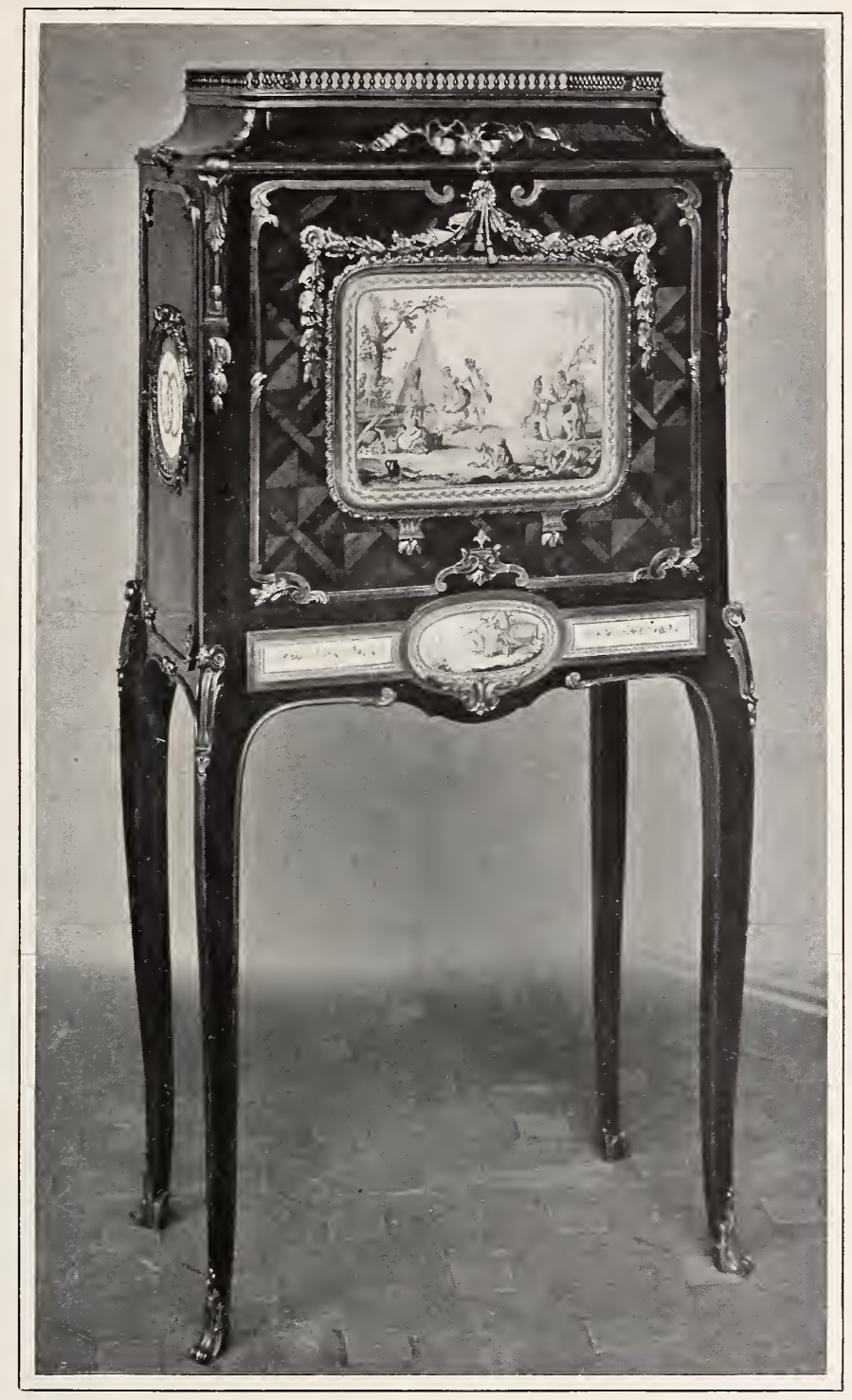

SìvRES (Pâte tendre).

Fig. 26.- Escritoire of Marquetry enriched WITH GILDED BRONZE, HAVING PANELS OF PORCELAIN WITH PAINTINGS, BORDERED BY A GROUND OF TURQUOISE AND RICH GILDING. PERIOD 1768.

Jones Bequest,

Victoria and Albert Museum. 

loved to surround herself with furniture with inlaid plaques of porcelain, and with the charming "biscuit" pieces of that factory. Her greatest preference appears to have been, however, for simple pieces, such as small vases to hold only a single flower-a pink or a rose-which she loved to scatter about in her little rooms.

We have already spoken of the furniture of the period which was enriched with porcelain, and during this reign numberless tables, writing-desks, jewel-boxes, dressing-tables and cabinets were made, the panels and drawers of which were ornamented with elaborately painted and gilded plaques of porcelain.

In the Jones Bequest, in the Victoria and Albert Museum, will be found a number of remarkable pieces of furniture of this epoch, in which, on priceless models of rich woods or fine marquetry, ornamental reliefs or mouldings in gilded bronze set off plaques of soft-paste porcelain. These plaques are decorated with flowers, either in colours or in gold, or with figure subjects, usually painted on a white ground. In Fig. 26 will be found an escritoire of rosewood from this collection, in which the porcelain plaques bear paintings of camp-scenes of the time of Louis XV., surrounded by a gilt border with a turquoise ground. Later, it became the custom to decorate the furniture with "biscuit" plaques of blue and white, grey and white, or seagreen and white, in imitation of Wedgwood's famous jaspers.

After Boileau's death, interested parties attempted to persuade Louis XVI. that the maintenance of Sèvres would be too great a burden on his resources, and that a company might be formed to maintain Sèvres in all its glory if the King would make a grant of the buildings and the grounds. The King; however, was very proud of the reputation of Sèvres, and determined to keep it in his own hands, nominating Parent as Boileau's successor. Parent appears to have been an active and industrious man, but quite incapable of managing an enterprise of such magnitude, employing at that time three hundred persons, many of them of the greatest distinction in their respective callings. He devoted his attention solely to the technical part of the business, and he did much for the improve- 
ment of the firing of the hard-paste porcelain, while he also understood how to choose clever painters and sculptors. But the business affairs became completely disorganised, and in 1778 Parent was imprisoned on a charge of malversation of the funds. Certainly the financial condition, after his few years of management, was disastrous, for more than 130,000 livres were owing to the workpeople and the purveyors of materials. It was necessary to change this state of affairs completely, to economise in every way, and to check the abuses that had grown up in the establishment. This task was entrusted to the Comte d'Angivillers, the director of the Department of FineArts, and the immediate control of the works was entrusted to Regnier, with whom was joined, in 1779, a Swiss chemist and geologist named Hettlinger, whom the Comte d'Angivillers had met and appreciated during a visit to that country.

One of the first difficulties experienced is a striking example of the difference between the periods of Louis XV. and Louis XVI., for it was discovered that the sale of the productions of Sèvres was being seriously interfered with by the hard-paste porcelains produced at other factories. We have seen how stringent were the edicts issued under Louis $X V$. for the protection of the monopoly of Vincennes and Sèvres, and how all other porcelain manufactories were forbidden to paint in colours, to model figures or flowers, or to use gold; but, after the discovery of kaolin, works sprang up on every side for the manufacture of hard-paste porcelain, the secret of which was very soon known, and these pieces were sold in the white, or decorated in blue, though with constant attempts to evade the edicts forbidding the use of other colours.

We shall recount the history of these various works in a subsequent chapter, but we may mention here that one of the first steps in all such undertakings appears to have been to secure the patronage of some great lord, or of one of the royal princes; while we shall find that one of the most important of them, was actually patronised by the Queen Marie-Antoinette herself. In this way the royal ordinances were evaded or defied, and these outside factories grew steadily in importance and 


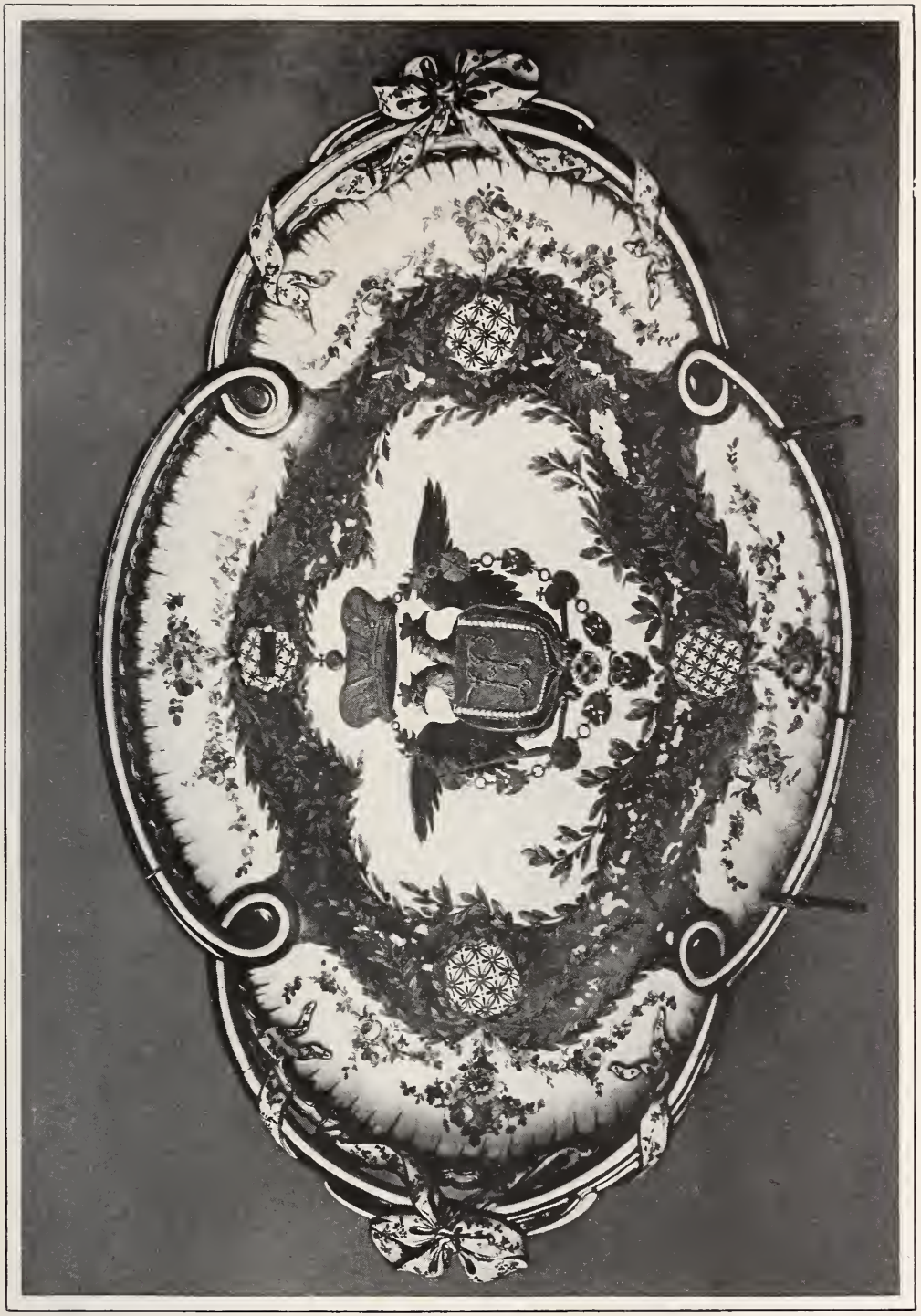

$\stackrel{0}{2}$

合

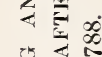

然

昰

远它

푼

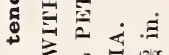

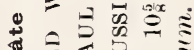

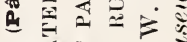

ผै

胥

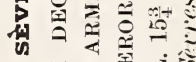

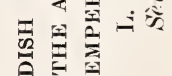

ลัง

క્વ 

reputation to the detriment of Sèvres. Indeed, it almost appeared as if nothing would be left to Sèvres but the making of the services and pieces intended for the use of the monarch and his entourage, and for the customary diplomatic presents. It was necessary to do something to curb the growing competition of these outside manufactories, and we find that on May 16, 1784 , an edict was published by the royal council, and countersigned by the King, reviving the older edicts and confirming the monopoly of Sèvres. It is amusing to read in this document that "the restrictions imposed by previous edicts had not been entirely observed, and that a few of the licensed manufactories having obtained special permission to decorate their pieces with gold, or with colours, all the other factories have taken advantage of this privilege to such an extent as to undertake and sell in competition with the royal manufactory of France every kind of porcelain, without excepting those the exclusive fabrication of which had constantly been reserved to it. . . . Several have made efforts to win and bring over the workmen to their manufactories, while there are even some who have taken the liberty of copying the marks of the royal factory . . . that at last these manufactories have increased in the town of Paris and in its neighbourhood to such an extent that they have caused a consumption of wood injurious to the supply of the capital, and that besides the quantity of porcelain made exceeds the sales that can be expected."

This royal order was notified to the interested parties in July, 1784, and the owners of the rival factories presented request after request, and petition after petition, to the King that he would postpone the execution of such ruinous measures. Then some delay was granted, doubtless by the interest of the Queen, the Comte D'Artois, the Duc d'Angoulême, and other persons of influence, who were the protectors of these factories, and we find M. d'Angivillers, writing on July 24, 1785, to M. de Calonne* :- "Being informed that you take an interest in having the verdict of the Council of May 16, 1784, concerning the manufacture of porcelain, delayed, I have given the director

\footnotetext{
* Calonne was at this time chief minister of Louis XVI.-ED.
} 
of the King's manufactory orders to put off for some time the execution of the provisions of this edict, by which those manufacturers had only one year to finish their orders, as well as the pieces previously made, the fabrication of which is forbidden for future times." In the end all the Parisian manufactories continued their industry, and while we have in these facts a significant example of the development of the liberal and social ideas of the time, we may also remember that if the edicts had been enforced the industry of hard-paste porcelain in France might also have been strangled at its birth. M. d'Angivillers wrote letter after letter to M. de Calonne to point out that the porcelain makers were evading the edicts in every possible way, especially in the use of gold; and he finishes by proposing again that the use of gold shall be restricted to the Sèvres pieces, and that apart from that the other porcelain makers shall be allowed to continue their industry. Finally on January 17, 1787, an edict was issued by which it was forbidden, under the severest penalties, to make any porcelain in the Sèvres style, unless by direct permission, "which can only be given when the perfection of each particular manufactory shall have been proved by an inspection, which shall be held every year for this purpose in the presence of commissioners elected by the King." It was further declared in this edict that the manufactories of the Queen, Monsieur (the King's eldest brother), M. le Comte D'Artois, and of M. le Duc d'Angoulême were recognised as fulfilling these requirements, and would enjoy the necessary permit. It was added that they were not authorised to make any pieces with gold grounds, or any articles of great luxury, such as porcelain panels or sculptured work in the form of vases, figures, or groups exceeding eighteen inches in height, not including the pedestals.

We shall find that the result of the Revolution of 1789 , which decreed in France the liberty of industry, abolished all these authorisations and monopolies which had pressed so injuriously on the development of the porcelain industry.

Let us now resume the direct history of the works at Sèvres. From 1779, when Hettlinger was elected director, we find that the shapes and models were gradually modified, the lines 
becoming simpler and purer; the style of Louis XV. was transformed into what we now know as the style of Louis XVI. It is, however, difficult to date by the form or decoration alone any piece of Sèvres porcelain, because of the repetition of certain decorations, from time to time, to meet the demands of patrons, and it must always be borne in mind that for some years before the accession of Louis XVI. there had been a reaction against the exuberant ornamentation which characterised the style known as Louis XV.

The reign of Louis XVI. saw the first production of the wonderful painted pictures on large plaques of soft-paste porcelain. This idea is said to have originated because of a fire, which destroyed in one of the royal chatteaux a valuable tapestry, and the managers of Sèvres had the idea of preserving in a permanent form a souvenir of such works of art. The magnificent series of plaques in soft-paste porcelain decorated with royal hunting scenes, after the tapestries of Oudry, which exist to-day in the museums of Versailles and of Sèvres, belong to this epoch, 1780 to 1782 .

The Victoria and Albert Museum possesses an example of this kind of work in the shape of a painting on a plaque of soft-paste porcelain, representing a young mother being shown her newlyborn baby. In 1783 it was intended to copy a picture designed for tapestry, "The Fête of the Sultana," after Pierre, but as the picture was not obtainable they 'copied, instead, one representing "The honours rendered to the Constable du Guesclin after his death."

At this period, too, was made a famous carriage decorated with porcelain. Bachaumont relates, in his "Secret Memoirs," that he saw in 1784, at Longchamps, a porcelain coach which caused a great sensation. Madame de Valentinois, the daughter of the Duchesse de Mazarin, one of the prettiest ladies of the court, attracted everybody's eyes by her beauty, but the Beaupré, a courtesan who made her first appearance on the course, caused an equal sensation by her carriage, which was decorated with panels of painted porcelain.

After about 1780 we find another influence at work on the 
artistic ideas of Sèvres. The excavations at Pompeii had brought to light many styles of decoration absolutely unknown to the eighteenth century, and from this time we find the decorative arts influenced by the "Antique." Hettlinger was brought into contact with Lagrenée, and with Vivant Denon, who sent him, from Naples, examples of the Etruscan and Roman vases. The Sèvres museum still possesses a very good collection of Etruscan vases given by Denon to Hettlinger, and these pieces, with their severe, almost solemn forms, and their antique decorations, had a profound influence on the forms and decorations of the Sèvres porcelain produced after this date.

It should also be remembered that hard-paste porcelain permitted the manufacture of very large pieces. The first of these appears to have been made in 1783 . There exist in the Louvre two very beautiful vases of this epoch. One, of the shape known as the "Medici vase," has a foot and neck in dark bleu de roi, with a girdle formed of "biscuit" porcelain and bronze, wonderfully sculptured. Before the manufacture of this large piece, a smaller pair of vases of the same shape was made, and these are also preserved in the Louvre.

Hettlinger himself describes these pieces as follows:- "We have made a porcelain vase of a very large size, about five feet high, and of a shape which leares nothing to be desired. On the body of the rase is displayed 'Atalanta's Race,' executed with unexampled perfection. This rare piece, in the compo sition of which 70,000 livres' worth of material has been used, was intended for a foreign court, but the King has reserred this for himself, and has ordered a second one to be made of the same size. Both are to be used for display in the galleries of the Louvre."

The foreign court for which this vase was intended was the Court of Tuscany, and a replica is to-day preserved in the Pitti Palace, in Florence.

A still larger vase is the "Vase Cordelier," made in 1785, decorated with a brown tortoiseshell colour, and bearing bronze cords supported by Cupids. Hettlinger wrote in 1785 that this bell-shaped vase on a truncated column, which he had 
just finished, was the biggest porcelain vase that had ever been made, and he appears to have been correct in this surmise.

During this period, the exhibitions at the end of each year. were still continued at the Palace of Versailles, and Hettlinger has left us his account of one of these ceremonies:

"I have already said that an exhibition of porcelains takes place at the end of every year up to the day of the "Three Magi' (Epiphany). It is held at the Royal Palace, but the public are allowed to come and examine and buy the pieces. The King occupies in Versailles, besides the State rooms, the Petits Appartements, where he passes his private life. Three of these rooms are cleared of their furniture, and the porcelain pieces are exhibited on tables. This year he did not wait until the arrival of the workpeople, but must himself be unpacking the pieces, breaking not a few, and mixing everything up so that it took us hours to put it straight. The King delights in his manufactory at Sèvres, and he said to one of his confidants, 'Our brave Sèvres men will soon be here. I must make haste to shoot some game.' The third day of the exhibition, the minister introduced me to the King, announcing in a loud voice my name and titles, to which he added, with his usual kindness, some especial praises of my knowledge and my skill in the art, asking me, at the same time, whether I had not got some proofs of it with me. I showed him two snuff-boxes decorated with birds, the decoration being made with natural feathers, which the minister handed to the King, who admired my work and my patience. . . . Our interview was very successful, thanks to an ingenious idea which had caused me to make some white porcelain pieces, attached to natural insects and put under glass shades, such as a 'Cupid in a car drawn by six butterflies,' and another 'Cupid as a huntsman,' where the dog was represented by a horn-beetle. While I was busily arranging" these things, the King came and laughed heartily, saying, "This must surely be your own invention.' He asked me how I trained the butterflies, and preserved the insects alive. . . . The delight of the King made these beetles so highly esteemed that they were sold at the price of a cow in Switzerland." 
If we have quoted the whole of this letter, it is that it may show, in the first place, the character of the King, who was more interested in silly butterflies and horn-beetles than in the beautiful porcelain pieces, decorated by the most eminent artists. It is also interesting as showing that Hettlinger was delighted that he could impress the King with his childish inventions.

We have already referred to the practice originated by Louis $\mathrm{XV}$. of making diplomatic presents in porcelain, and we find that this custom was continued during the present reign. Thus we read in the records of the Ministry of Foreign Affairs that in 1775 the Princess of Asturias was presented with a white dinner service, decorated with flowers and landscapes, and an epergne in Sèvres "biscuit," worth more than 24,000 livres. In 1777 the German Emperor was presented with a dinner service with a green border, decorated with paintings of flowers and fruit, as well as an epergne and two vases bearing his medallion, worth altogether 43,000 livres. In 1778, four tea and coffee services were made for the Emperor of Morocco and his Ambassador; while in 1779, a magnificent present of Sèrres porcelain was sent to the Emperor of China, consisting of vases, jars, figures and statuettes in "biscuit," after Boizot. These statuettes represented St. Louis, St. Clotilde, St. Antoine, St. Claire and St. Theresa. We have found terra-cotta models of these charming statuettes in the museum of Sèvres.

In 1784, on the occasion of his visit to Paris, Prince Henry of Prussia was presented with a tea service in soft-paste porcelain, decorated with translucent enamels; with a dessert service having a green border decorated with flowers; and with a series of "biscuit" statuettes representing famous Frenchmen. The rough, terra-cotta models of these statuettes of famous Frenchmen, including Corneille, Racine, Molière, Condé, Du Guesclin, \&c., are also preserved at Sèvres.

This leads us to say that toward 1780 the art of applying opaque or transparent enamels in relief on soft-paste porcelain, was first introduced. Sometimes these spots of enamel were arranged on gold foil, which gave them beautiful and varied re- 


\section{PLATE XVIII.}

\section{SEVRRES}

(PÂTE TGNDRE, ABOUT 1780).

\section{"Jewelled Sèvres" Vase}

With Bleu-de-roi Ground, enriched with Enamels and Gillding. The Painting, representing "Pygmalion and Galatea," attributed to Dodin, after a Composition by Falconet.

Wrllace Collection, No. 25, Gallery XVII. 



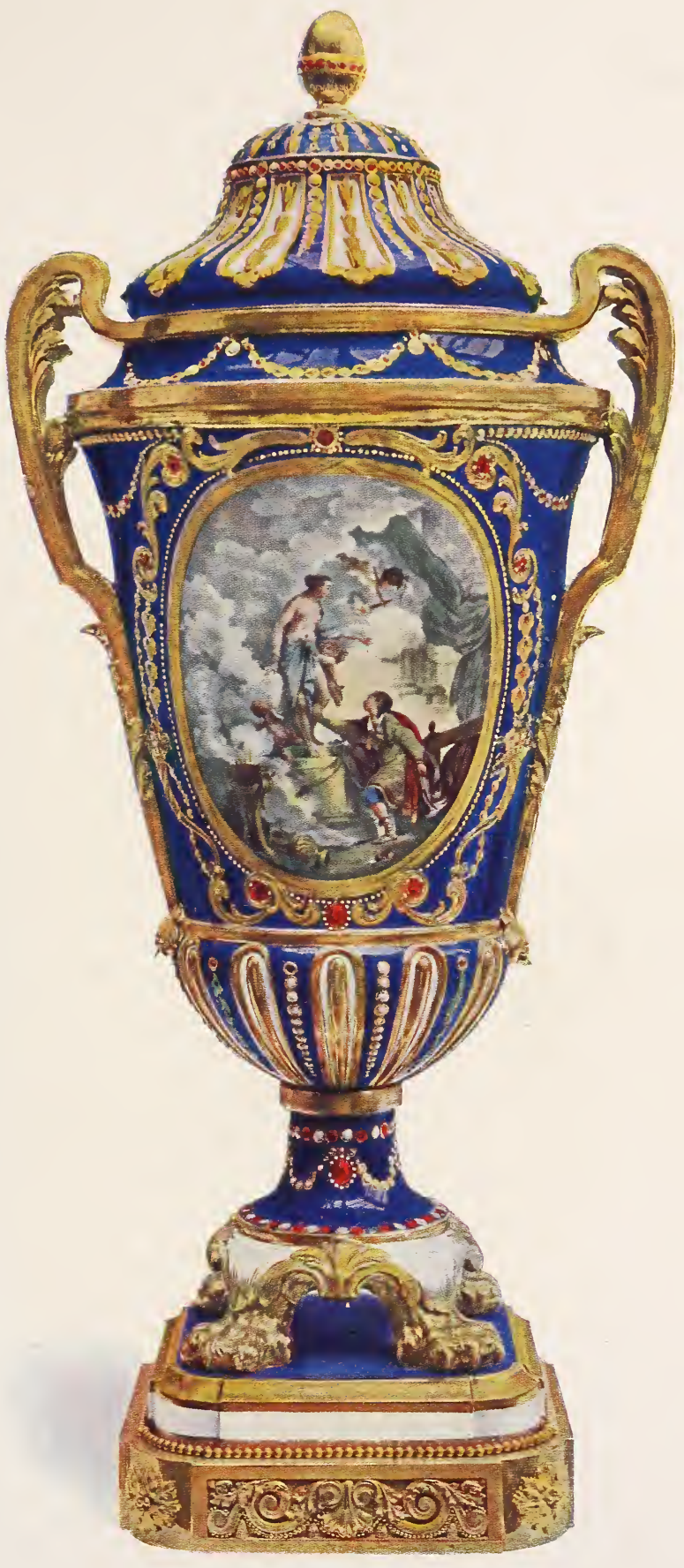



flections, so that after the firing and gilding were completed, the porcelain appeared as though it were actually jewelled with rubies, emeralds, sapphires and pearls; hence the name applied to this variety-"Jewelled Sèvres." We illustrate a magnificent vase of this description, from the Wallace Collection (see Plate XVIII.). It may be remarked that these pieces are exceedingly rare, which is not to be wondered at considering the difficulty of successfuly manufacturing pieces which required so many repeated firings. It should also be said that forgeries of "Jewelled Sèvres" are by no means uncommon, though such forgeries are generally very inferior imitations, as down to the present time we believe no such pieces have ever been made in the old Sèvres method.

In addition to the making of diplomatic presents, we must also state that during this period orders were frequently given to the Sèvres manufactory by foreign Sovereigns; as, for instance, when, in 1780, Marmontel was charged by the King of Sweden with the choice of a number of pieces to be offered to the Empress of Russia. Marmontel's letters prove that he selected the following pieces:-

(1) A large vase in bleu de roi and gold, with a cartouche representing a shipping scene. In this little picture two men are represented as reading in a book, placed on a hogshead, and it was agreed between Marmontel and the painter that he should inscribe on the book the words: "Catherine II.-Gustave III. Neutralité Armée 1780."

(2) Two groups representing Pygmalion and Prometheus.

(3) Two vases of bleu de roi ground, with foliage, arranged as cornucopiæ.

It may be added that the first of these objects is now displayed in the Jones Collection in the Victoria and Albert Museum, and we find that the marine painting was executed by Morin, the flowers by Fontaine, and the gilding by Leguay. The models of the two groups representing Pygmalion and Prometheus are still preserved at Sèvres, and we shall refer to them again in the chapter on "Sèrres Biscuits."

The most famous of the commissions from a foreign 
sovereign during this period was the order for a dinner service given by Catherine II. of Russia, before 1775. This service was to be decorated and painted in the most sumptuous manner; the borders of the pieces being of rich turquoise blue, ornamented with cameos, copied from those in the museums of Rome or Naples, and with rich gilding. Plate XIX., reproduced from a piece of this service now preserved in the Victoria and Albert Museum, will convey a good idea of its lavish richness. This particular plate was decorated by Chapuis and Boulanger, and gilded by Prévost, about 1777. It should be mentioned that pieces of this service are often found in museums and collections, because, during a fire at the Palace of TsarkoeSelo, a certain number of the pieces were stolen, and afterwards sold.

When this service was delivered in 1788, the Empress Catherine refused to pay the sum of $331,317 *$ livies which had been charged for the 744 pieces. A voluminous correspondence followed between the Foreign Ministers of the two countries, but we are unable to say when, or how this question was decided, if it ever was decided, because the Revolution of 1789 broke out soon afterwards.

We have already referred to the personal influence of MarieAntoinette on the productions of Sèvres, and we must now consider her influence a little more in detail. In 1781 she invited Pajou to model a group representing the Queen presenting to France her son, the Dauphin (see p. 110). On one of her visits to Sèvres in connection with this work, she had a cup made, the form of which was absolutely new, and which was always called "The Queen's Cup." This cup, of a somewhat truncated form, has its handles formed by gilded dolphins. The cover, mounted in bronze, was formed in the shape of a royal crown, while the saucer was provided with an inner rim, (trembleuse), to prevent the slipping of the cup. The ground of the cup and saucer were in turquoise blue, decorated with bouquets of roses, and lilies surrounded by wreaths of the

* This figure, which differs from that given by previous writers, has been taken rom the records of the French Foreign Office.-Ed. 


\section{PLATE XIX.}

\section{SEेVRFS}

(PÂTE TENDRE, ABOUT 1777).

\section{Plate}

Of the Service Executed for the Empress Catherine II. of Russia; Decorated by Chapuis, sen., and Boulanger; thr Gilding by Prévost.

Dia. $10 \frac{1}{4}$ in.

Victoria and Albert Museum. 



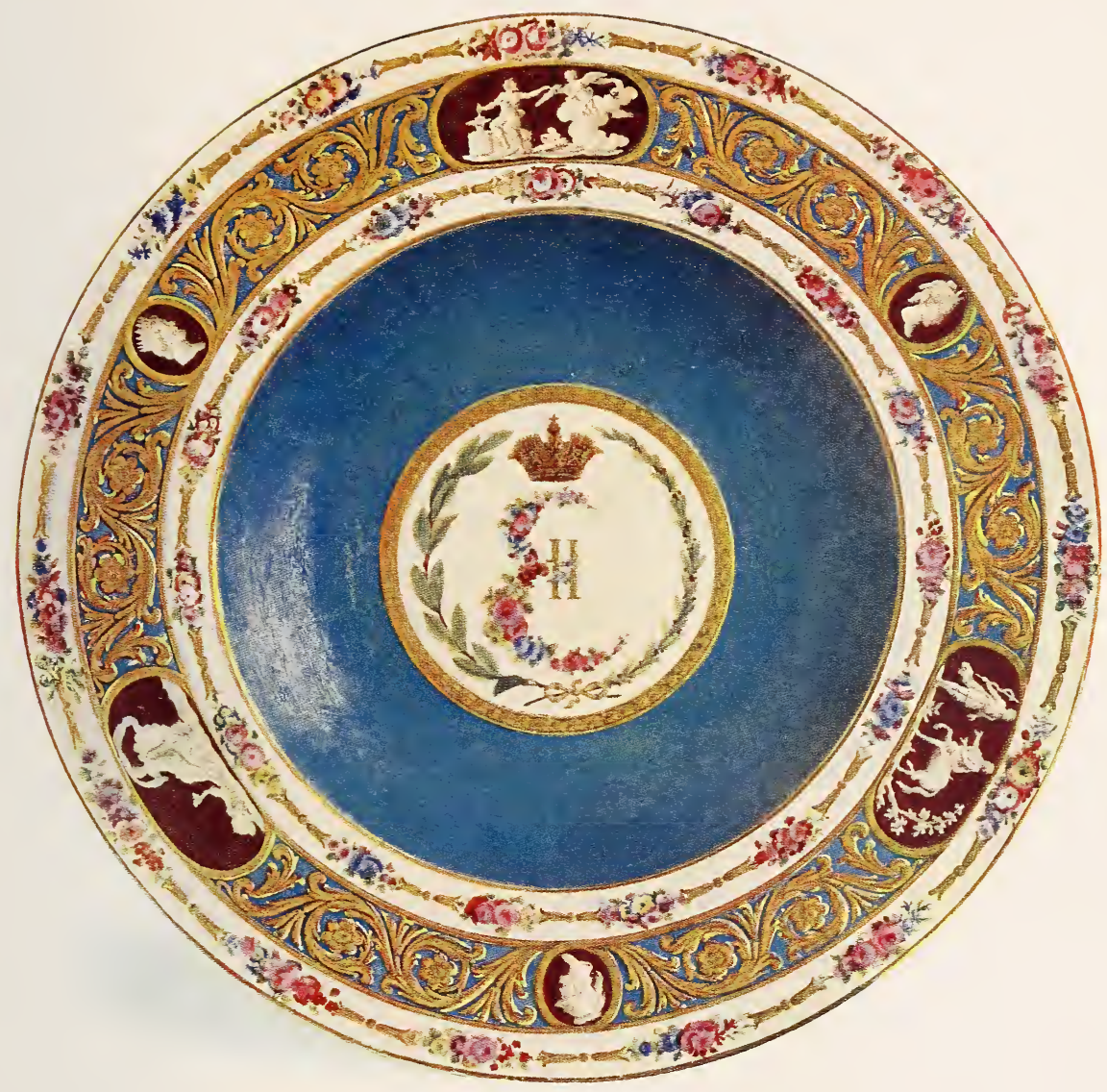



same flowers. This piece was included in the Double sale in 1881.*

About this date, Marie-Antoinette also patronised a factory which had been founded in 1788 by André-Marie Lebœuf, at rue Thiroux, Paris. The productions of this factory bear the mark "A" surmounted by a royal crown, and are therefore known by collectors as Porcelaine à la Reine.

In 1782 the King and the Queen visited Sèvres, with the Count and Countess du Nord, $\uparrow$ and Marie-Antoinette paid the most marked attentions to the Countess. She brought her to admire a magnificent dressing-table, decorated with porcelain with a lapis-blue ground-a recent masterpiece of the establishment-and on the Countess du Nord exclaiming that such a magnificent piece must surely be intended for the Queen, Marie-Antoinette showed her that it was decorated with her own coat-of-arms, and was, indeed, a present which she had designed as a surprise for her.

About 1782 the Queen, whose favourite colour was blue, and who loved to dress herself in blue, complained during one of the exhibitions at Versailles about seeing nothing but roses, tulips, and jonquils used in the decoration of the porcelain pieces. Hettlinger, who, as we have seen, knew how to please their Majesties, iminediately thought of using a little blue corntlower, of which the Queen was very fond, as a painted decoration for the porcelain pieces. This cornflower decoration (décor barbeau) became quite a rage, not only at Sèvres, but at all the porcelain factories of the time. In Fig. 29 will be found a reproduction of a Sèvres plate of soft-paste porcelain, decorated, in 1787, by Buteux with this cornflower pattern.

When one considers how the French Revolution caused the dispersal, not merely of all the furniture of the royal châteaux, but also of the furniture of the émigrés, it is not astonishing that there should be so few souvenirs belonging to MarieAntoinette preserved in France. In one of the small rooms in

* The cup afterwards passed into Mr. Goode's collection, and was again sold, with the rest of his Sèvres porcelain, at Christie's in 1896.-ED.

+ Afterwards Emperor Paul I. and Empress of Russia. 
the Palace of Versailles, which was used by the unfortunate Queen, there is a small clock in soft-paste porcelain, decorated in turquoise blue with rich gilding, and this is, perhaps, the only untouched household article to be found there. In this connection it is of the greatest interest to record the survival of one or two pieces of the porcelain ordered by Marie-Antoinette for the farms at the Petit Trianon and at Rambouillet, where she delighted to spend her days of leisure. For these farms, all the milk-dishes, the cheese-trays, the butter-dishes, the cups and saucers, the churn, the milk-buckets and the jugs were of porcelain, made either at Sèvres or at the factory in the rue Thiroux, at Paris. We reproduce in Figs. 30 and 31 a cup and saucer from one of these laiteries, now preserved in the Sèvres Museum. In addition we know only of a large milk-bucket, with a capacity of nearly thirty litres, which was made at Sèvres about 1785. This bucket is decorated with sculptured goats' heads, and has been often copied in modern times, and the copies sold as veritable pieces of the Queen's service.

In conclusion we must mention that during this period soft-paste porcelain still continued to be made, and one of its distinguishing features is a very pale canary-yellow ground, which made its appearance for the first time. The hard-paste porcelain was gradually improved and perfected also, and certain ground-colours were introduced, which were made by superposing colours on the already fired glaze, and re-firing at the same high temperature (au grand feu). In this way, by the use of cobalt, a ground colour known as bleu de Sèvres was obtained, and by diluting it with glaze, pale blue, or flaxen-blue, generally mottled or marbled, was also obtained. With a mixture of iron and manganese the ground-colour known as tortoiseshell-brown was obtained, which reached its full splendour when it received a third firing at a lower temperature in the muffle kiln. With a mixture of blue and this brown tortoiseshell, the famous "green tortoiseshell" colour, so highly prized by collectors, was produced. We must also say that a fairly complete palette of colours for painting on the glaze of hard-paste porcelain was perfected. To this period, likewise, 

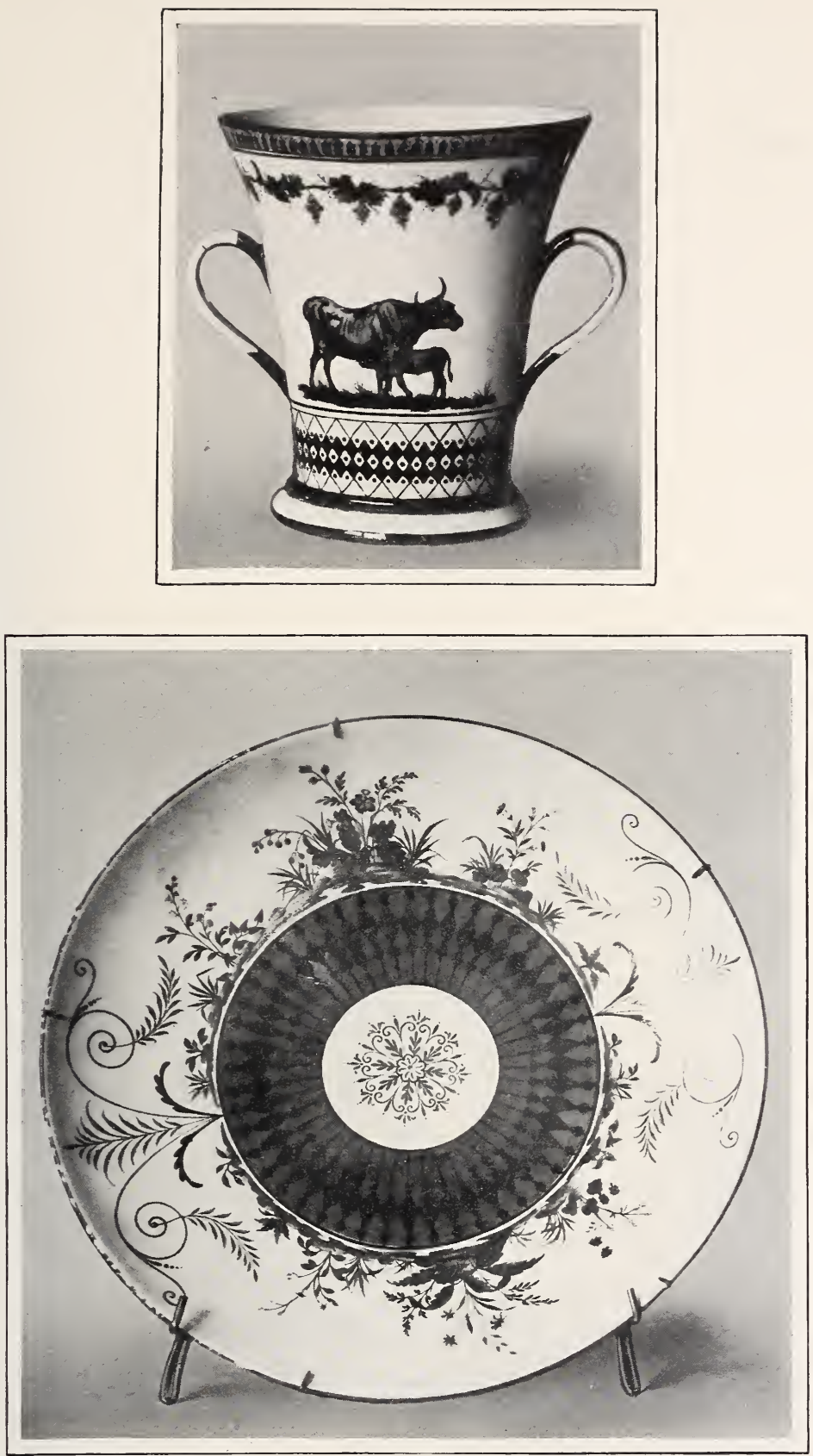

Sìvres (Pate dure).

Figs. $30 \& 31$ - CUP AND SAUCER MADE FOR "LA LAITERIE DE TRIANON." PERIOD 1785.

Cup, H. $4_{2}^{\frac{1}{2}}$ in. Saucer, Dia. $7 \frac{1}{2}$ in. Sèvres Museum. 

belong the small snuff-boxes, painted with miniature seascapes or landscapes, figure groups, or more rarely, flowers and birds. About 1775 Hettlinger also manufactured marbled, or agatelike pieces, in imitation of Wedgwood's agate wares, and these were frequently set in gilded mounts.

The most famous sculptors were Le Riche, Perrotin, Mathians, Léance, Desprès and Levaux. The figure-makers and modellers employed in sharpening and finishing the soft-paste pieces included Deperais, Brachard, Roger, Beslé, Chaponet, Plocque, Furet, Martin-Bougon and Humber, an excellent flower maker; while in the workshops for the hardpaste porcelain we find Deparis, Bono, Caron, Borniche, Martin, and Age, assisted by about thirty other workmen.

Genest was the chief painter, and he was assisted by about one hundred and twelve persons, the most famous of whom we have already mentioned as being employed in the factory at the end of the reign of Louis XV.

The date marks from the year 1774 to 1777 comprised the letters from " $V$ " to " $Z$ "; while in 1778 the date mark was "A A"; in 1779 , "B B"; and so on until 1792, when the pieces were marked "O O." We shall speak further on as to the marks employed during the revolutionary period. 


\section{CHAP'TER XIII.}

SÈVRES "BISCUITS" UNDER LOUIS XV. AND LOUIS XVI.

THE "biscuit" groups and figures produced at Sèvres were of such artistic and technical importance that it has seemed to us necessary to give them special attention, such as they have not hitherto received. The first "biscuit" pieces were made in softpaste porcelain, and were fired only once, so that the name "biscuit" can only be explained on the supposition that it was borrowed from the faïence-makers, who had given that name to their material when it was not glazed. After 1769 the "biscuit" pieces of Sèvres were executed in hard-paste porcelain, as this material, having greater plasticity, was easier to use. After the moulding, and especially after a careful sharpening, or touching up, of the moulded piece by a skilled modeller, or figure-maker (répareur), to which so much of the merit of the Sèvres pieces is due, the pieces, being properly dried, were carefully supported in the manner we have already described (see p. 9), and were then fired in the most sheltered and protected parts of the porcelain oven. Every effort was made to obtain pieces possessing a beautiful grain, similar to that of fine marble, but without any glaze or shine on the surface; and after the pieces were taken out of the oven, the seams left by the joints of the mould were carefully rubbed down by hand. The "biscuit" pieces made in the soft-paste porcelain are not very close in the grain, and are slightly amber-coloured. Those in hard-paste porcelain, produced during the eighteenth century, have a closer grain, and are of a dead white colour; their artistic value is also lessened by the fact that the seams left by the joints of the mould are often visible. 


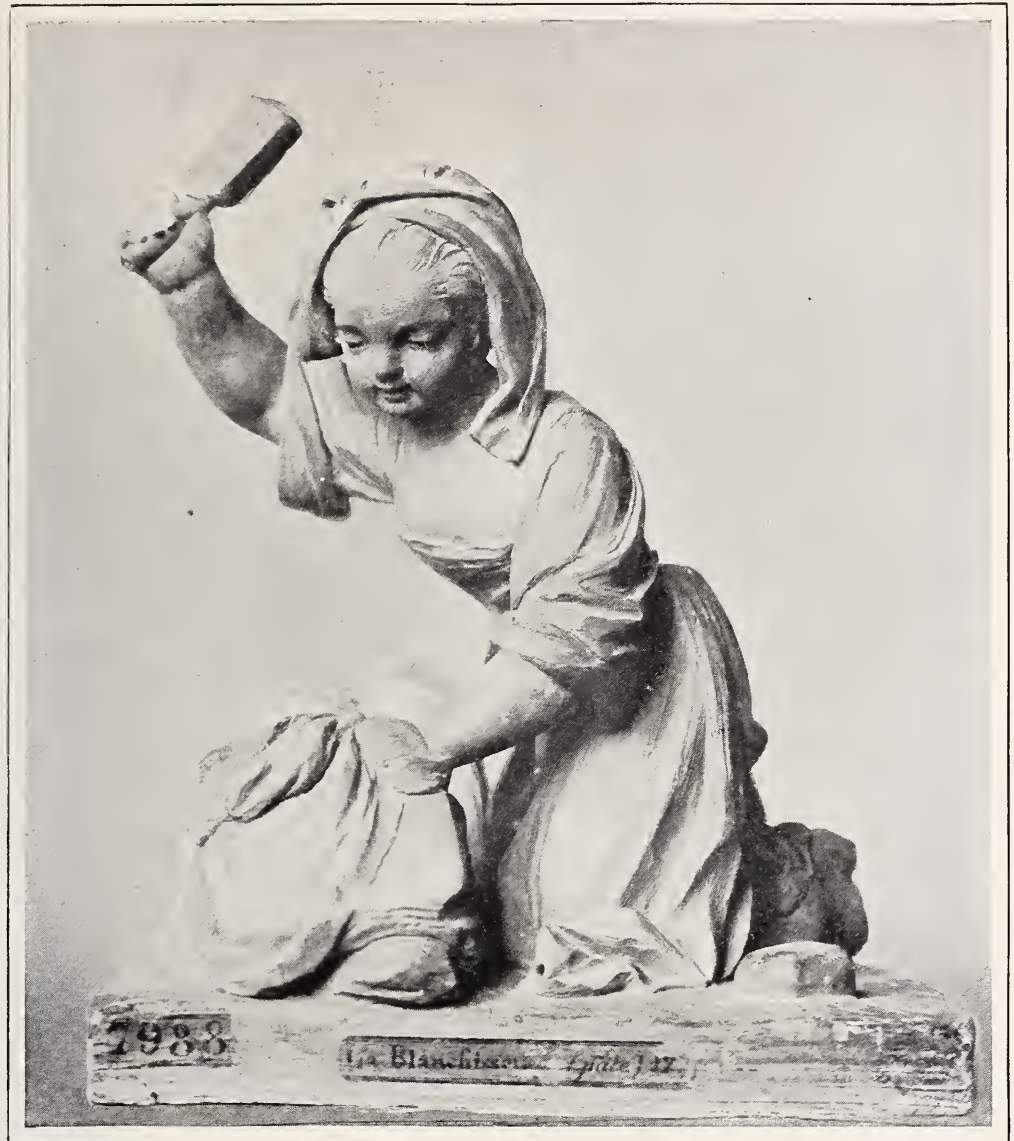

SìvREs.

Fig. 32.-BiSCUIT FigURE-"The WaSherwoman." DATE ABOUT 1781.

H. 7 in.

Sèvres Museum. 

It must not be forgotten that the original models for these "biscuit" pieces, were made by some of the most eminent sculptors of the time-Pajou, Pigalle, Clodion, La Rue, Caffieri, Falconet, Boizot, Julien, Le Riche, etc.-and that they comprised not only busts, but elaborate groups of various kinds. We emphasise this fact in order to direct the reader's attention to the very great difference between the Sèvres "biscuits" and the little figures produced by the German manufactories, particularly those of Meissen and Frankenthal. These works made an endless variety of graceful, charming, and affected little figures, brightly enamelled, the gaiety of which, in the drawing-room or boudoir of the period, was their principal recommendation. The Sèvres "biscuits," on the contrary, have a serious artistic value, which puts them on an entirely different plane. A profusely illustrated volume would alone serve to describe the most important of the pieces, and it is to be hoped that the illustrations we are able to give will direct the attention of English amateurs to this fascinating branch of Sèvres porcelains.

The busts produced during this period were few in number; but they make up in quality what they lack in quantity. The Municipal Library of Versailles possesses a bust, in soft-paste porcelain, of Louis XV., splendidly posed, which we can only attribute to Pajou. Although we have no knowledge of any bust of Madame de Pompadour, Pajou made three different busts of Madame Dubarry, which are extremely beautiful; the three models differing from each other in the details of the draperies, and the arrangement of the hair. Only two examples of these busts in porcelain are known, one in the library at Versailles, and the other in the museum at Sèvres, but these give us a fine idea of the care with which such busts, or portraits, were executed.

Pajou afterwards modelled a bust of Marie-Antoinette, while she was still Dauphiness, as we have mentioned in the preceding chapter (see p. 94). This bust was extremely difficult to fire in the full life-size, so that it was afterwards reduced, and many copies of the reduced size are known. Afterwards Boizot modelled a bust of Marie-Antoinette as Queen, and one of Louis 
XVI., which have been freely reproduced, both at Sèvres and at other factories. We have already mentioned a group of 1772, the "Marriage of Louis XVI.," which we owe to Pajou, while in 1781 we find the same artist producing a group symbolising the birth of the Dauphin, in which the Queen, with a gesture of the utmost simplicity, presents to France her royal child.

La Rue sculptured the children of the royal family, and his figure of Madame-Royale, naked on a cushion, is of very great beauty; most of the other children of the royal house were also modelled by Pajou. About 1782, a number of figures of famous men were modelled by Pigalle, Caffieri, Pajou, and Boizot; among which we may mention the seated figures of Molière, Racine, Corneille, and the famous standing figures of Catinat, Vauban, and Condé.

Among these statuettes of standing figures are D'Aguesseau, by Berruer (1779); Vauban and Bayard, by Bridan (1787); Catinat, by Dijoux (1781); the "Chancelier de l'Hôpital," by Gois (1777); Tourville, by Houdon (1781); Fénelon, by Lecomte (1777); Duquesne, by Monot (1785); Sully, by Mouchy (1777); Bossuet (1779); Descartes (1777); Turenne (1773), by Pajou; Condé, by Roland (1786); and especially the wonderful seated figures of Racine, by Boizot (1785); of Pierre Corneille (1779) ; and of Molière (1783), by Jean-Jacques Caffieri ; of Mathieu Molé by Gois (1785); of La Fontaine, by Pierre Julien (1783); of Rollin, by Lecomte (1787); of Pascal, by Pajou (1781); and finally the figure of Montesquieu (1779) by Clodion, one of the finest works of this master, distinguished by the dignity of its pose, and the richness of its draperies. In connection with these figures it may be remarked that Boizot conceived the idea of making a "biscuit" figure of Louis XVI. standing, and of life size; for this was the period when they strove to create monumental works in porcelain. For such a purpose it was necessary to prepare a special paste, more plastic than the usual porcelain material, and to this end a little plastic clay was added to the other ingredients, producing a slightly yellowish body. This paste was not used for the lifesize figure of Louis XVI., as that figure was never actually 


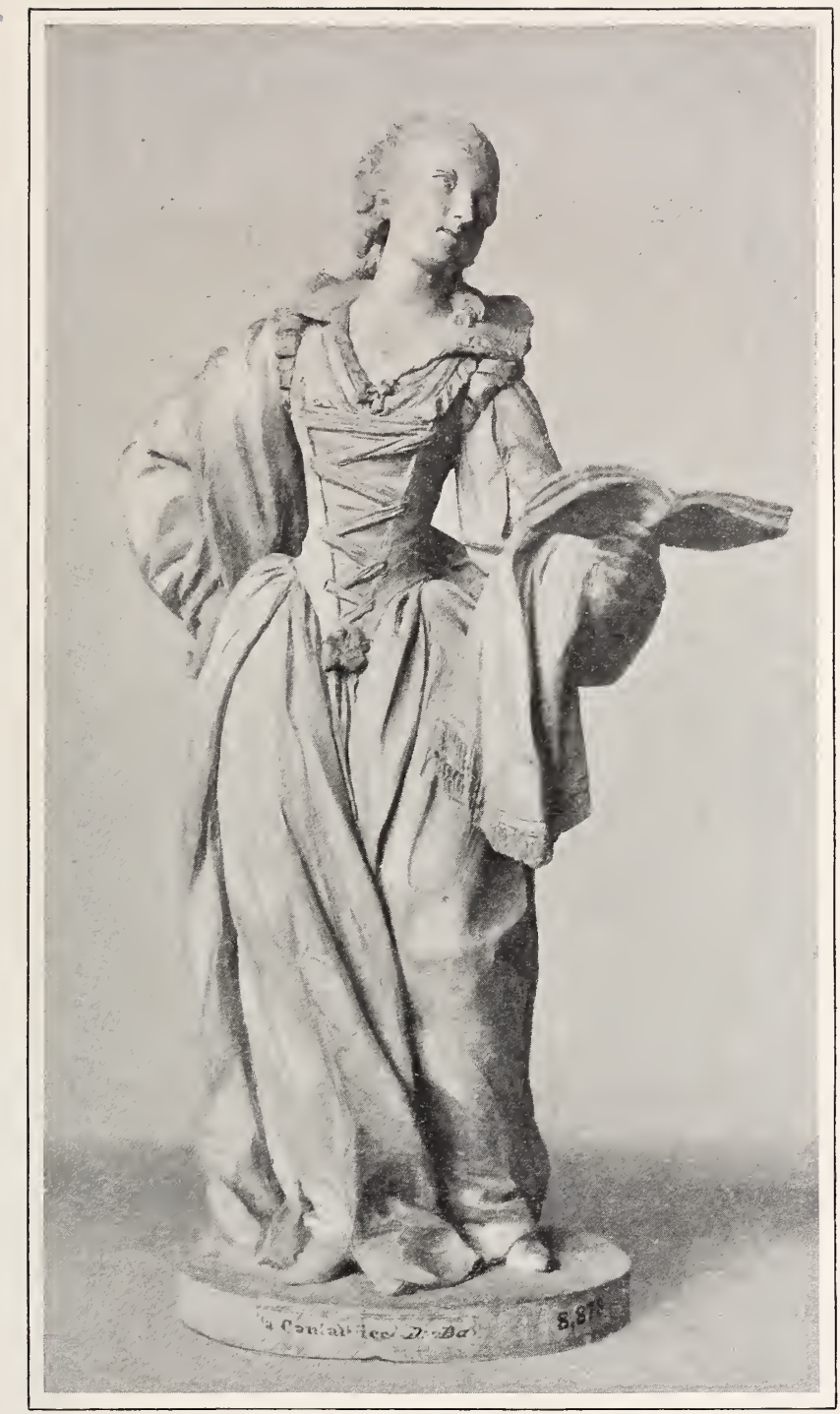

SìvRES.

Fig. 33.-BisCUIT FIGURE-THE SINGER, DUbARRY, ABOUT 1772.

H. 9 in.

Sèvres Museum. 

finished; but it was used for the production of other large pieces, which we shall mention further on.

The sculptor, Le Riche, had a special talent for seizing a likeness, and as his work was full of intelligence, it will be found that he produced a large number of the portrait-models made at Sèvres. He is said to have made an excellent portrait figure of Captain Laroche, the overseer of the menagerie and the poultryyard at Versailles, who was treated very familiarly by Louis XVI. Laroche was very proud of this honour, and when one of the courtiers, for a joke, placed opposite his figure one of Volanges, the actor, in the character of Jeannot (of which we shall speak presently) he broke it to pieces before His Majesty exclaiming: "Sire! who is the wretch who has dared to put the bust of an actor by the side of a brave soldier, decorated with your orders?" The King smiled, and his only reply was: "Captain Laroche, I saw in the yard of the Château, in the direction of the Orangery, a peacock strutting about; if a similar thing happens again I shall break you at the head of your company."

Le Riche also sculptured an adventurer of the period who passed himself off as the son of the Great Mogul, and this little "biscuit" piece became quite a rage, and was to be found in all the boudoirs.

We must also mention the busts of Franklin and Voltaire, a delicious equestrian statuette of Frederick the Great, and a bust of the Emperor Joseph II. The sketches of the busts of Diderot, and of Jean-Jacques Rousseau, belong to the first years of the Revolution.

The great rage of the period, so far as portraits, busts, and figures were concerned, seems to have been concentrated on the actors and actresses of the day. The museum at Sèvres preserves the original terra-cottas of a great number of charming statuettes, which give us a vivid idea of the theatrical stars of the latter part of the eighteenth century, and it should be added that the museums of the Opéra, and of the Comédie Française in Paris, contain a considerable number of these same figures in "biscuit" porcelain. 
There is the statuette known as the Singer Dubarry, representing the King's mistress about to sing (see Fig. 33). We have no exact information as to who modelled this charming figure, but by the style and handling we are inclined to attribute it to Pajou, and to date it about 1772. The principals of the "Corps de Ballet" of this epoch, the dancers at the Opéra, the Spanish singers who came to Paris in 1774, and the royal dancers of the Fair of St. Germain, are all represented (see Figs. 34 and 35). Le Riche also seems to have delighted in commemorating the successes of some of the minor theatres. A piece by Dorvigny (Les Battus paient l'amende) had a great success at the Fair of St. Germain; and the characters of Jeannot and Jeannette, a silly valet and a nimble soubrette, delighted all Paris. A débutant, Volanges, acted the part of "Jeannot," and was represented, with "Jeannette," in Sèvres "biscuit."

Afterwards, the production of these theatrical characters became the fashion, and we find all the actors, actresses, dancers, and singers of the period represented in porcelain. A group known as "Annette and Lubin" reproduced the features of Madame Favart in the rôle of Annette, and of Cailleau as Lubin; while the group of the "Shepherdess of the Alps," of which we give a representation (see Fig. 36), recalls the pieces in the affected country style contemporary with the Petit Trianon.

Volanges in the character of Crispin; Préville as Figaro; Mlle. Contat as Thalia; and La Guimard as Melpomene recall the plays of La Harpe; while the delightful little statuette entitled "La Tambourinaire" is a souvenir of the piece " $L a$ Provençale," produced in 1778. On the stage at the Fair of St. Germain, "Les Eaux de Merlin," by Le Sage, was played. The principal characters, a negro and a negress, were modelled by Le Riche, and of these excellent models several hundred copies in "biscuit" must have been made. According to MM. de Goncourt, the sculptor Merchi made, in 1780, a figure of La Guimard, with Théodore as a shepherdess, Heinel as a nymph and other actresses as bacchantes; but up to the present time we have not been able to trace any of these pieces.

On the occasion of the marriage of Marie-Antoinette, in 1770, 


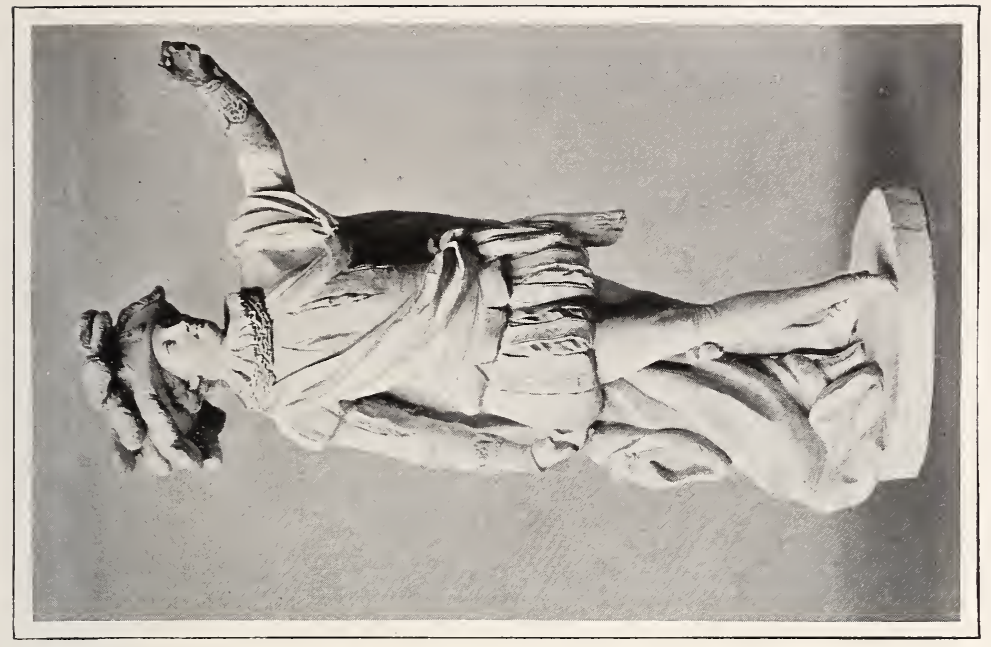

吾
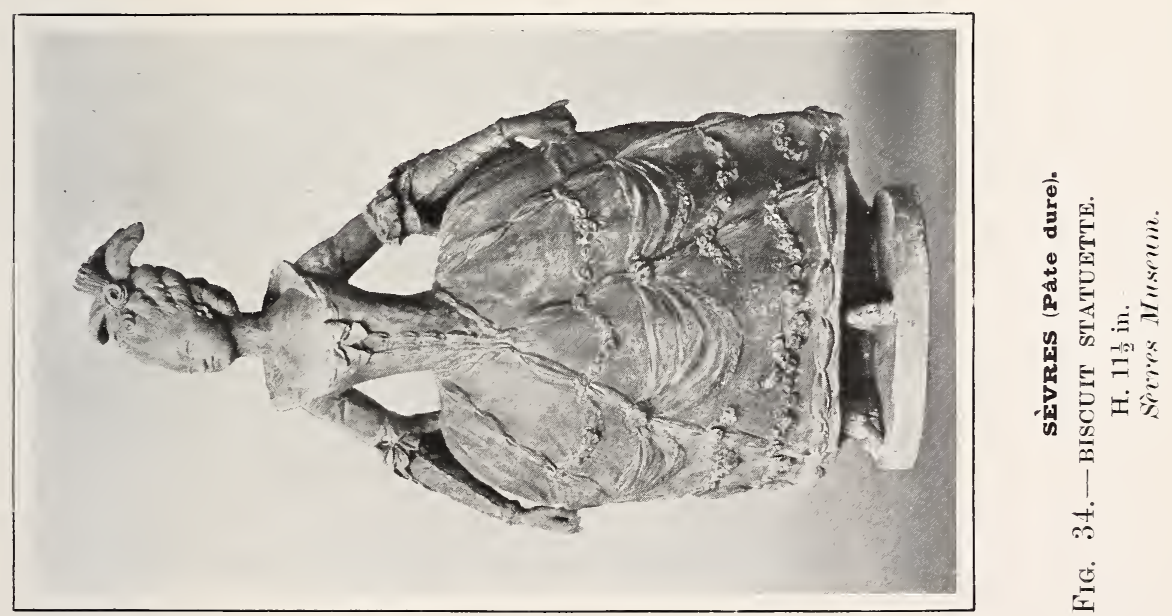



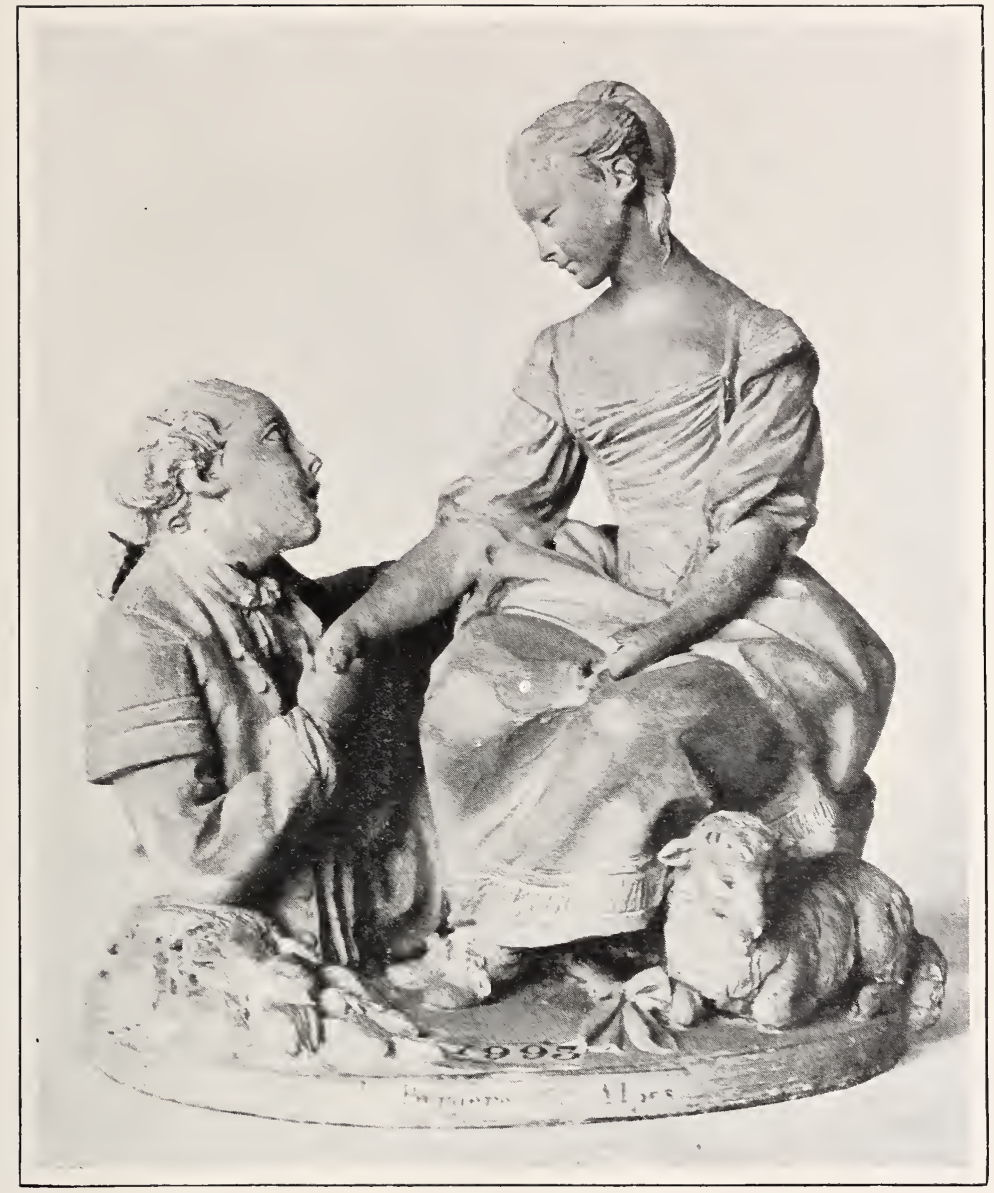

SìvRES.

Fig. 36.-Biscuit GROUP-" The ALPINE ShePherdess." MODELLED 1780.

H. $6 \frac{1}{4}$ in.

Sèrres Museum. 

the opera of "Perseus and Andromeda," by Quinault and Lulli, was produced, and a symbolical group was made at Sèvres representing this sensational performance, in which Legros sang the music of "Perseus," while Vestris, La Guimard, and Heinel danced the ballet. In $\mathbf{1 7 7 9}$, Gluck's "Iphigenia in Tauris" was first played in Paris, creating a tremendous sensation, and a magnificent commemorative group of four figures, of unusual beauty, was produced at Sèvres.

In addition to these pieces commemorating well-known actors and actresses, or some successful theatrical production, the fame of which has come down to our own day, there are still preserved at Sèvres both groups and single figures, representing dancers of both sexes, whose names we are absolutely unable to trace, though many of these models are of the utmost charm and grace.

Nor were these "biscuit" pieces called forth only by the successes of the theatre. They were equally evoked by the fashions of the moment in art and in literature. Thus we have a famous series of groups, illustrative of "The History of Don Quixote," though from the date of the production of these pieces it is possible they were made in rivalry with the famous tapestries of Gobelins, illustrating the same immortal work. A reproduction of one of these groups, known as "Sancho Panza" (see Fig. 37), illustrates perfectly the spirit which informed the groups, the charm of the arrangement, and the skilful treatment of the costumes.

We have already mentioned the famous royal hunting scenes, after Oudry, which had been reproduced both in Gobelins tapestry and in paintings on soft-paste porcelain. An Italian sculptor, who came to Paris, also modelled, under Bachelier's direction, the chief subjects of these hunting scenes, in the form of magnificent groups for table decoration. The famous "Surtout des Chasses" has for centre-pieces the hunting of the wolf and the hunting of the wild boar; while the side pieces represent hunters with guns, hunters with horns, huntsa men and whippers-in, who wear the royal livery of the period. This magnificent piece of art has been reproduced several times 
during the nineteenth century, in spite of the extraordinary difficulties of its fabrication.

But the greatest number of the groups and figures of Sèvres were dedicated to the God of Love, and after the famous "Cupid" of Falconet, which was originally used as the lid of a vase, we soon find various other groups making their appearance; such as "Cupid Grinding his Arrows," "Cupid Triumphant," "The Theft of the Rose," "The Birth of Love," "Love and Faithfulness," "Love Led by Folly," etc.; while in praise of beauty we find a series, containing: "The Triumph of Beauty," "Homage to Beauty," and, finally, "Beauty Crowned by the Graces," which is reproduced in Fig. 38, and which serves to show the artistic value of such pieces, modelled by unknown sculptors working on the suggestions or ideas of Falconet, Pajou, or Clodion.

We must also point out the groups, "The Kiss Given" and "The Kiss Taken," modelled in 1760, which are obviously influenced by the style of Boucher. Neither must we forget that subjects of inspiration were also found in the life of the streets, from the common people, giving us a series of most artistic figures, among which we number a buffoon, a fisherman, a hunter, a nurse, a school-master, a school-mistress, a magiclantern group, a fish-woman and a flower-woman (two famous figures by La Rue), a tailor, a dandy, a mole-catcher, and several figures of knife-grinders. In this connection we must again refer to the figure of a little washerwoman (Fig. 32), so natural in its pose and movement, and so beautifully and graciously rendered. At a later period, we observe the influence of the sentimentality of Greuze, evoking certain groups of paralytic fathers and guilty daughters.

We may well imagine that mythological subjects were not neglected, particularly in the latter part of this period, when the results of the Pompeiian excavations were attracting so much attention. We may mention, of this kind, the "Achilles" group, containing five figures; the group of "The Adieux of Paris and Helen"; and the "Judgment of Paris"; while we have already mentioned the famous groups of "Pygmalion " and "Prometheus," 


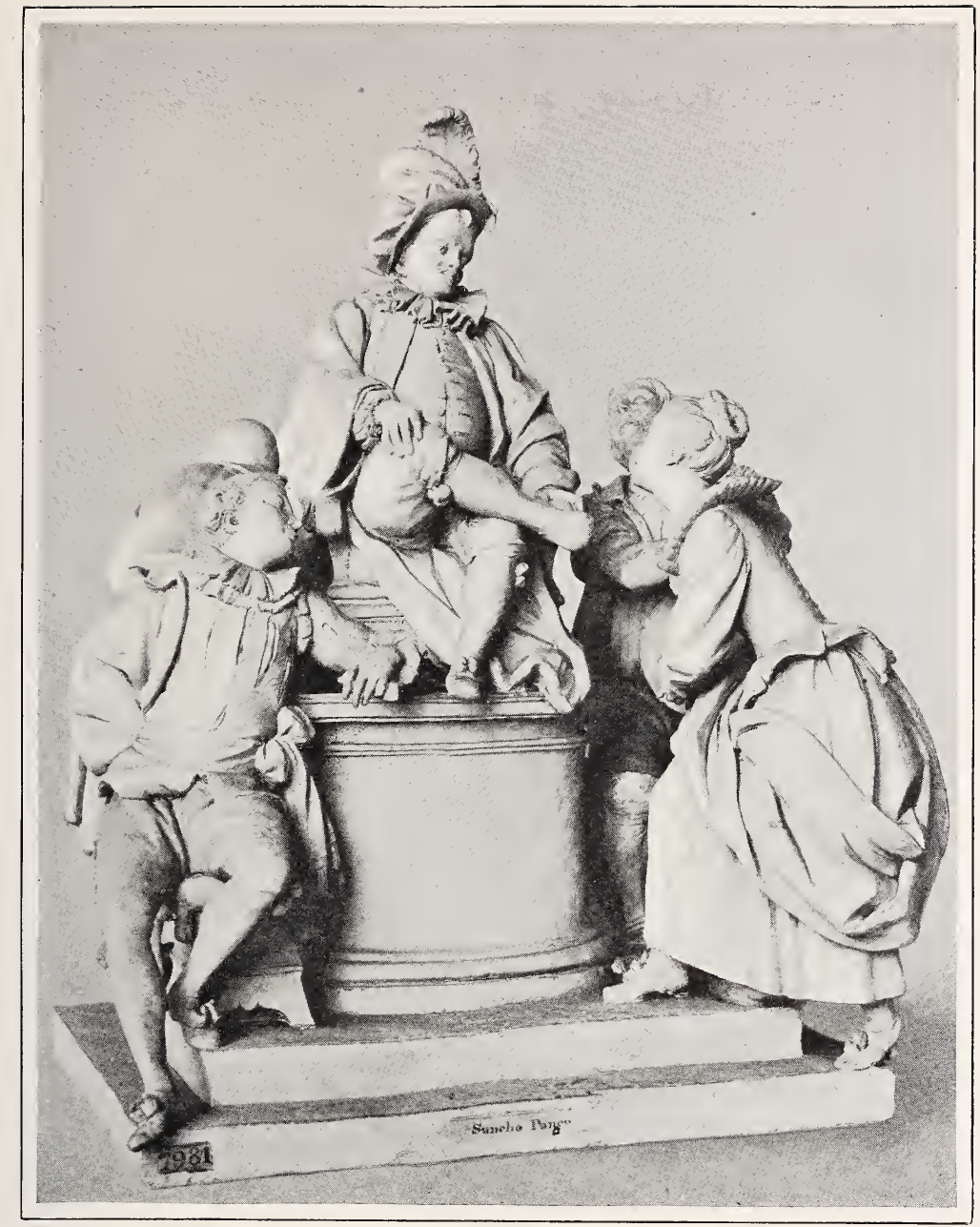

SìvRES.

Fig. 37.-Biscuit group-" sancho Panza." ONE OF A SERIES ILLUSTRATING THE HISTORY OF DON QUIXOTE.

H. $14 \frac{1}{2}$ in.

Sèvres Museum. 



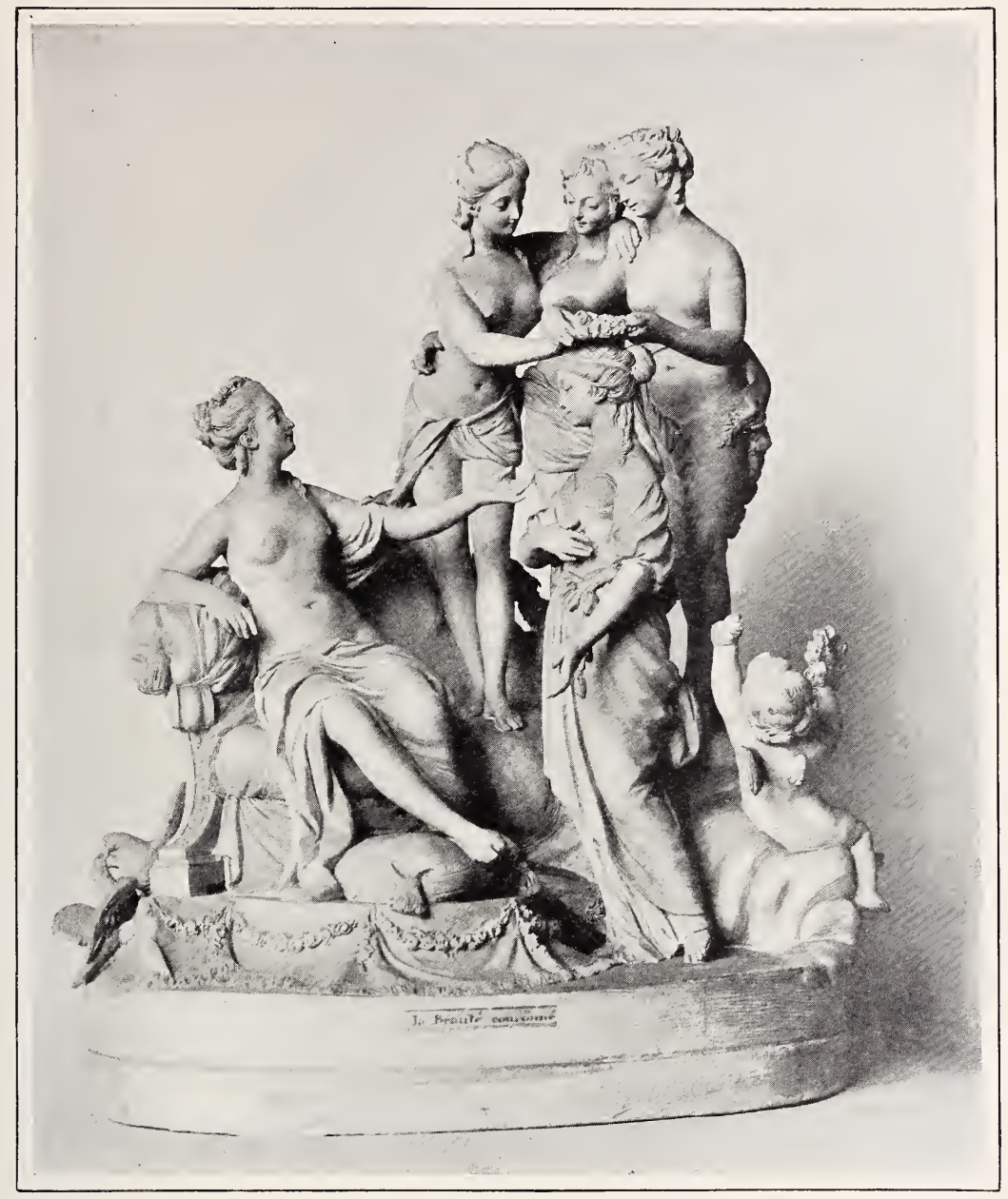

Sìvres.

Fig. 38.-Biscuit Group-" BEAUty CROWNED." PERIOD 1775.

H. $14 \frac{1}{2}$ in.

Sèvres Museum. 

which are attributed to Daru. For our own part we think that while the "Prometheus" may be attributed to this artist, the "Pygmalion" is much more likely to have been the work of Falconet, as the beauty of its lines, and the simplicity and elegance of the figures, bespeak the hand of this master. From his hand we undoubtedly possess the celebrated fernale figure "La Baigneuse," a work that opened for him the doors of the Academy of Fine Arts. The dimensions of this figure rendered necessary the use of the special paste first prepared for the lifesize figure of Louis XVI. (see p. 110), and it is to this fact that we must attribute the greyish tone of the magnificent example preserved in the Victoria and Albert Museum. Falconet made a companion figure "La Baigneuse aux roseaux," and it must be said that reduced models of these figures in various sizes have vulgarised the famous works. The figure of "Leda," by the same master, is much less known, but deserves the approbation of collectors.

Reverting for a moment to the mythological subjects, we must mention that remarkable work, the "Surtout de Bacchus," which consists of a number of groups intended to form a table decoration. In the central group, a number of nymphs crown Bacchus with flowers, while the side pieces are formed by nymphs and goddesses, adorned with garlands of flowers carefully made by hand; while little Cupids, mounted on pedestals, carry lights.

The story of "Telemachus" was also illustrated by a group of five figures, in a style which would date it as belonging to the reign of Louis XVI.

Mention must also be made of the purely decorative works of Clodion, and of Boizot's small bas-reliefs, modelled on a tinted porcelain ground in the style of Wedgwood's bas-reliefs, and largely used for the decoration of furniture; while a word must be given to the "biscuit" clocks, in which porcelain parts were used, along with rare marbles, and gilded or ungilded bronzes. Symbolical figures, such as "Time" and "Study," were frequently used to frame the dial plates, while in other examples we find decorative arrangements of figures of no symbolical significance. 


\section{CHAPTER XIV.}

THE HARD-PASTE PORCELAIN FACTORIES OF FRANCE, FROM THE DISCOVERY OF KAOLIN TO THE REVOLUTION.

WE have already stated that the result of the discovery of kaolin near Alençon in 1760, and afterwards at St. Yrieix (near Limoges) was the introduction into France of the manufacture of hard-paste porcelain. The lack of precise documentary evidence prevents us from describing these efforts in due chronological order, so that it has seemed preferable to treat this new development of the industry rather by groups of factories, according to the different artistic impulses developed in various districts of the country.

\section{THE EAST OF FRANCE.}

STRASBURG.

We have already recounted how this industry originated in Strasburg, and how Paul-Adam Hannong had negotiated for the sale of his secrets to the royal manufactory at Vincennes (see pp. 73-74). We have also narrated how his son, PierreAntoine, was driven to found the works at Frankenthal. It was left for Joseph-Adam, the other son, who directed the works at Strasburg and Haguenau, to take up the fabrication of hardpaste porcelain in 1766. He seems to have contented himself with a large commercial production, instead of aiming at perfect or artistic work, for several of his letter's are in existence in which he says how dangerous it is for a potter to look for perfection, and points out how his grandfather and his brother 

had suffered financially from following such a course. Joseph Hannong, however, was a clever potter, as well as a good man of business, and Tainturier, the historiographer of the Hannong family, states that he left a treatise on the fabrication of earthenware and several volumes of his experiments on the management of the firing of porcelain. In any case, this manufacture of porcelain by the third Hannong in Strasburg ceased about 1780 .

We have put forward the supposition that the first essays in the making of hard-paste porcelain at Strasburg were made with kaolinitic materials obtained from Passau (see p. 72), and from the MSS. of Joseph Hannong we learn that he used, about 1760, white clay (kaolin) from Oberzell, between Passau and Linz on the Danube, together with a reddish clay found near Oberkirch (Baden), along with white sand and plaster. He made many experiments with clays procured from different places in Alsace, but without any success.

The porcelains of Joseph Hannong are generally heavy and thick in substance, the body being somewhat tawny. The glaze often shows defects, which are hidden by little flowers or insects, or even by spots of black colour. The decorations are in two styles; either copies of Chinese designs, or paintings of flowers, similar to those used on the Strasburg faïence, and following the same style the beads and mouldings of the pieces are often picked out with lines of a very characteristic violet-carmine colour. Gilded pieces are extremely rare. In addition to the purple, or carmine colours, indigo-blue, green, yellow, and a pale rose-colour were very much used, as well as a bright red, made from oxide of iron. We illustrate as an example of this period, a vegetable-dish of Strasburg porcelain, now in the Sèvres museum, which bears the mark " $\dot{H}$ " in underglaze blue. It may be stated that his mark is often accompanied with figures referring to the works-numbers of individual pieces.

Joseph Hannong made some statuettes and groups, enamelled, and painted in imitation of those of Dresden; while he also made "biscuit" pieces in hard-paste porcelain, marked with an impressed "H." This mark is frequently accompanied by numbers or letters relating to the shape of the piece. 


\section{NIDERVILLER.}

'Towards 1754 Baron Jean-Louis de Beyerlé, one of the King's counsellor's, and the Director of the Strasburg mint, whose wife was a talented artist, founded a works in Niderviller, producing faience of a high quality, decorated in bright colours in the Strasburg style. The chemist of this works, named Anstett, is said to have been the first to employ the purple of Cassius (the basis of the gold-purple colours) in the decoration of faïence.

In 1765, it was decided to manufacture hard-paste porcelain, and for this purpose workmen seem to have been enticed from Saxony, so that by 1768 a commercial production of hardpaste porcelain had been established, for the first time, in France, as at that date the industry had not passed beyond the experimental stages at Sèvres. At first German kaolin was used, but MI. de Beyerlé had the fortunate idea of buying some of the first kaolin mines at St. Yrieix, and he thus improved the quality of his productions.

In 1780 the works passed into the hands of General the Comte de Custine, and it was managed for him until 1793 by François Lanfrey, a potter of great note, who not only developed the porcelain industry, but also introduced a manufacture of faïence fine, or English earthenware. Lanfrey was not only a successful potter himself, but he succeeded in attracting from Lunéville the famous sculptor Lemire, who produced a great number of little figures and statuettes which helped to make the fortune, as well as the artistic repute, of this works. Charles Sauvage, called Lemire, had been employed at the faïence works at Lunéville, and had worked with Cyfflé on the little "biscuit" figures which this sculptor had brought into fashion. Iemire, however, possessed distinct individuality, and it is fairly easy to distinguish between the works of Cyflé and those of Lemire. Cyffé was, in fact, a boon companion, who loved to treat jovial subjects and popular types, while Lemire was, by instinct, a decorator, who modelled children, Cupids, shepherdesses, vases, and groups of pure and elegant form, in the style of Louis XVI.; 


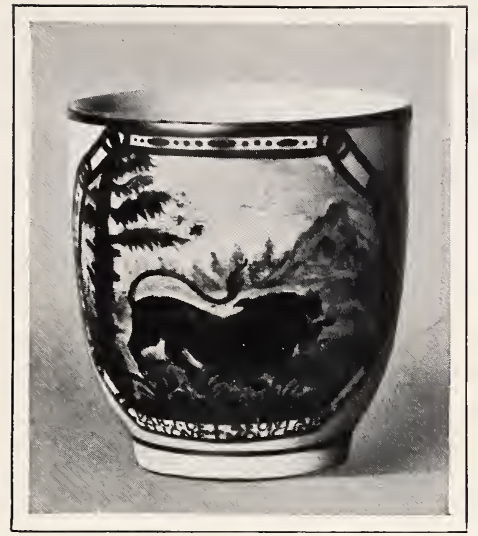

NIDERVILLIR (Pate dure).

Fig. 40.-CUP DECORATED WITH SUBJECT FROM LA FONTAINE'S "FABLES."

H. $3 \frac{1}{8}$ in.

Sèrres Museum.

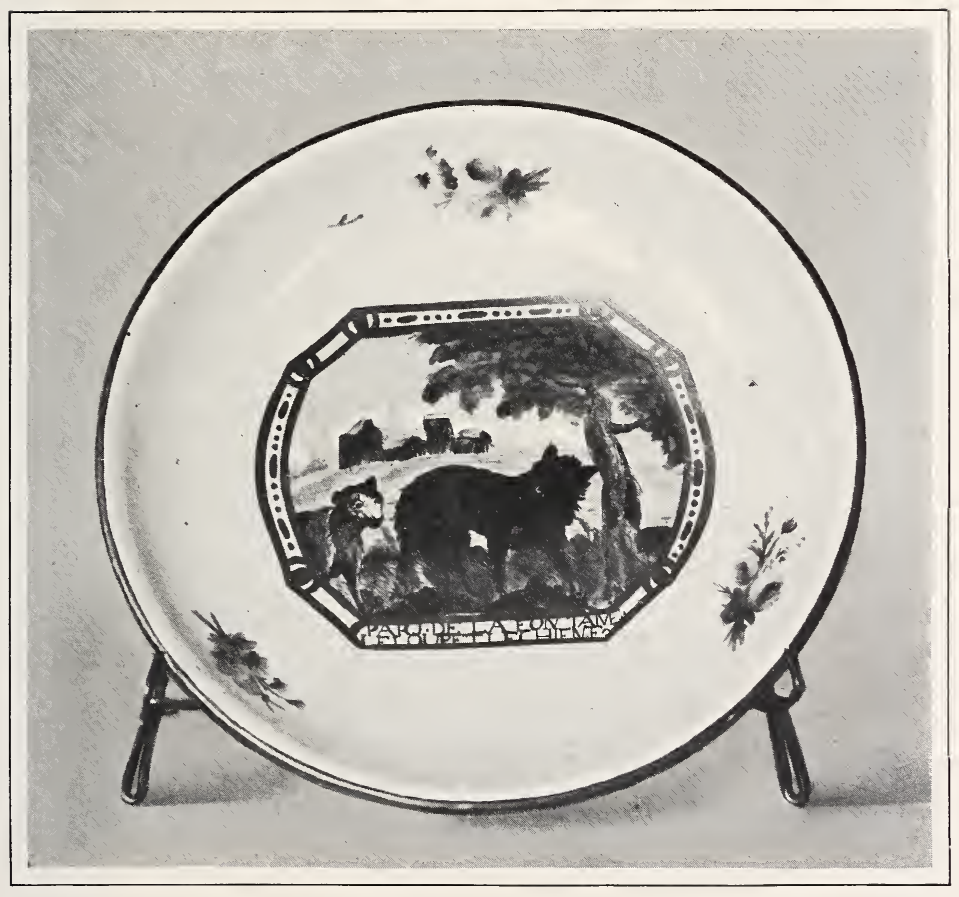

NIDERVILLER (Pâte dure).

Fig. 41.-SAUCER Decorated With SUbJect FROM LA FONTAINE'S " FABJ.ES."

Dia. $5 \frac{1}{2}$ in.

Sèvres Museum. 

and notwithstanding the date, Cyflés work, is more in the manner of Louis XV. It was through the employment of Lemire that the "biscuits" of Niderviller were produced. He is said to have modelled a magnificent allegorical group, now in the museum at Colmar. This group was commissioned by the town of Strasburg to be displayed in the room reserved for MarieAntoinette when she came through Strasburg in May, 1770, on her journey to marry the Dauphin, afterwards Louis XVI. It is in the form of a triangular altar, the front of which bears in golden letters the inscription "Cara Deûm Soboles." On the altar are two shields bearing the arms of the Dauphin, and of the house of Austria and Lorraine. On the left a standing winged figure, crowned with flowers, holds with his right hand the torch of Hymen between the two shields, which he seems to illumine, while with his left hand the figure twines a garland round the shields as well as the altar. At the base of the altar lies a rose branch with a bud, and a little farther off is a rose broken off its stem, and half faded. This work, which is extremely skilful in execution, is perfectly characteristic of Lemire's talents. Not only was Lemire a successful artist himself, but he had the idea of establishing, in connection with the works, a school of modelling and design for the apprentices, with such excellent results that Niderviller was able to retain its high repute for artistic productions for a long time. In 1806 Lemire settled in Paris, and established a sculptor's studio there.

After the death of the Comte de Custine, Lanfrey remained the director of the works, and steering it through the stormy times of the Revolution, he afterwards became its proprietor. On his death, the works was directed by a M. Dryander, and it survived until the middle of the nineteenth century.

The first porcelains of Niderviller, those of the Beyerlé period, are extremely translucent, the decoration being strictly analogous to that in vogue at most of the German factories, which all, more or less, followed the style of Meissen. In Figs. 40 and 41 will be found a reproduction of a cup and saucer of this period, decorated with painted illustrations drawn from La Fontaine's fables. They are inscribed in the borders "Par J. de la 
F'ontaine," "Le lion et la moucheron" and "Le loup et le clien," the little flower painting on the saucer is in rather bright purple and rose-colour, but there is no gilding, the framing of the pictures and the bands being in dark carmine colour.

The period of the Comte de Custine is characterised by a less vitreous paste, which was covered by an extremely beautiful and brilliant glaze, similar in appearance to the Sèvres glaze of the same period. During this period the pieces were sometimes gilded. A fine example of this gilded work is reproduced in the small ewer and basin preserved in the Sèvres Museum (see Fig. 42), which dates from 1780, and which shows how every care has been taken to approach the excellence of the Sèvres manufacture. The tableware was generally decorated with roses, forget-me-nots, and little Howers, either scattered over the pieces in detached sprays, or arranged in the form of bouquets. One of the finest productions of the factory was a dinner service made for the Comte de Custine himself, bearing his coat-of-arms and the motto "Fais ce que dois, advienne que pourra," disposed within a little flag. The borders of the pieces were pierced, and the pierced pattern was outlined with rose and lilac lines. Pieces of this service, which are extremely beautiful, are highly appreciated by amateurs.

The artistic direction of Lanfrey was particularly distinguished by the groups and figures, either in "biscuit," or glazed and decorated. These pieces had so great a vogue at the end of the eighteenth century that no fewer than three hundred different models were produced.

We are enabled, by reference to a recently discovered catalogue of these figures, to mention the following pieces, which were the work of Lemire: "The Cake Vendors" (Marchands d'oublies), "The Cobbler," "The Old Clothes-mender," "The Beggars," together with the shepherds and shepherdesses; while the famous group of figures known as "Paris Cries" are also due to the same hand. Besides these, he produced a certain number of allegorical figures, such as "Bacchus and a Bacchante," "Jupiter and Juno," "Apollo," "Venus," \&c. The museum at Versailles possesses an excellent group in "biscuit" which 


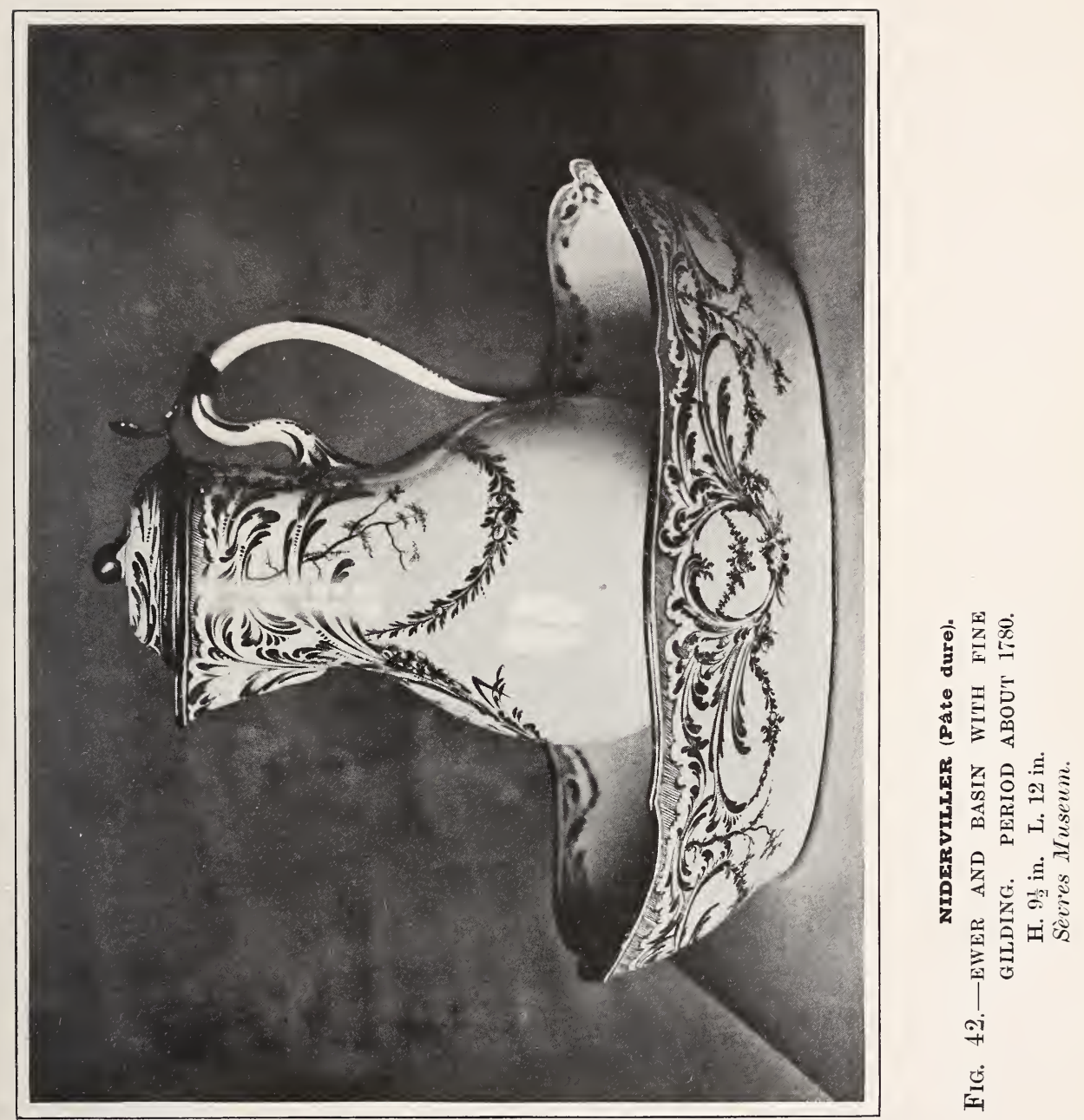



should probably be attributed to Lemire, and which represents "Sully on his knees before Henry IV."

Other figures were made after the models of Cyffé, such as "The Four Seasons," "The Chimney Sweep," "The Savoyard," "The Pastry Cooks," \&c., as well as vases ornamented with masks. Some of these "biscuit" vases are over three feet in height.

Porcelain flowers were also made at Niderviller, while after Sèvres had set the fashion of the "cornflower" decoration (see p. 105), this style was extensively copied also. It should be added that the figures and groups are irreproachable in execution, and command high prices, nowadays, at auction.

It is generally stated that the marks during the Beyerlé period were an impressed " $B$," or an " $A$ " and " $N$ " interlaced, but as a matter of fact, during this period there was no regular mark. During the time of the Comte de Custine the mark was generally the letters " $\mathrm{C}$ " and " $\mathrm{N}$ " interlaced. Afterwards, the mark consisted of two " C's" crossed, and surmounted by a count's coronet, which should not be confounded with the mark of the factory at Louisbourg; while in 1792 we find either the letter " $N$ " or the word "Nider," or "Niderviller" in full, and Lanfrey's mark was formed of the letters "C. F. L." interlaced. All these marks are in blue under-glaze. The "biscuit" pieces and the statuettes are seldom marked; if they are, it is with the impressed word "Niderviller."

\section{LUNÉVILLE.}

We have no absolute certainty that true porcelain was ever made at Lunéville, though the faïence factory there produced some very fine groups and figures in a greyish-white paste, on which are stamped the words "Terre de Lorraine" or "Cyffé c̀ Lunéville," sometimes bearing in addition the signature of some artist, as for instance, François. In spite of the fact that these figures are often spoken of as porcelain, it must be pointed out that properly speaking they are not porcelain, but only a species of fine white earthenware, as the paste can be rubbed away with a steel tool. 


\section{NORTH OF FRANCE.}

LILLE.

About 1783 Leperre-Durot attempted to establish at Lille a manufactory of hard-paste porcelain. He asked to be authorised to put over his door the Royal coat-of-arms, with the inscription "Manufacture Royale," and he begged to be freed from the town dues. He obtained this privilege for a term of fifteen years, and the town of Lille granted him a subsidy of 12,000 livres, so that by 1784 the manufactory was in full work. An attestation, drawn up by the municipal officers of Lille, stated that he fired his porcelain with coal, and that the said officers were present when an oven containing 2,359 pieces was drawn, and they were just as nice and white as if they had been fired with wood. In 1785 Leperre was authorised to display over the main entrance of his works the words "Manufacture Royale de Monseigneur le Dauphin," this great favour being granted him only because he had been successful in firing hard-paste porcelain with coal. Experiments in this direction at the factory of the Comte d'Artois in Paris (see p. 131) had come to nothing, and Leperre was called to Paris in 1786, to give an official demonstration of the firing of hard-paste porcelain with coal. The intrigues of some of the other manufacturers, however, prevented him from giving this demonstration. There is preserved in the museum at Sèvres a porcelain saucer decorated on the border with drawings of the chemical apparatus and symbols used by alchemists, while outside this is written "Fait à Lille en Flandie. Cuit au Charbon de terre, 1785."

A magnificent table-service was made at Iille in 1786, and was sent to Paris for the use of the Dauphin.

The Lille hard-paste porcelains have an extremely hard white paste, with a beautiful glaze. They are often elaborately decorated by a skilful hand, as will be seen from the jug, now kept in the Sèvres museum, which is reproduced in Fig. 43. The pieces are often solidly gilt with thick gold. Plates, cups, 


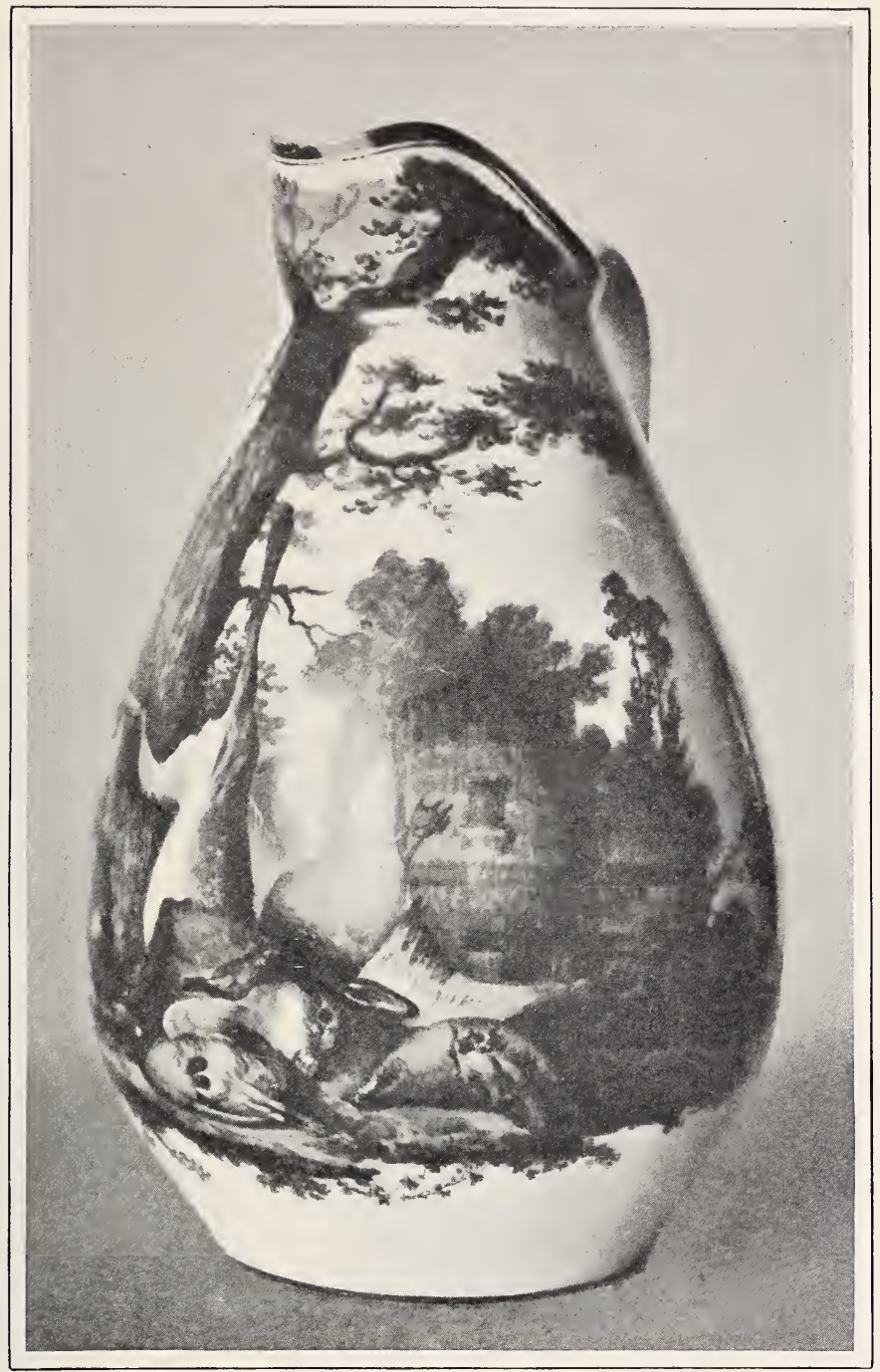

IILIE (PÂte dure).

Fig. 43 - Jug decorated with paintings OF DEAD GAME, ETC H. $9 \frac{1}{2}$ in.

Sèvres Museum. 

saucers, and other table-pieces were made, as well as figures, but we are not aware of the production of any statuettes or "biscuit" pieces at this factory. In 1804, a prefect of the department described a group representing the "Descent from the Cross," after a picture by Rubens, which was considered a masterpiece for the attitude and expression of the figures, the fineness of the paste, and the size and finish of the work.

Leperre had as his principal assistant one Vannier, who appears to have been the real inventor of the method of firing with coal, for as soon as Vannier left these works and went to Valenciennes, the firing became quite unsatisfactory, and in 1789 they were obliged to go back to the use of wood as a fuel.

In 1790 Leperre sold his establishment to M. Gaboria, and from this time to about 1801 the works passed from hand to hand, without any further success in face of the formidable competition of the soft-paste porcelain of Tournay. The general mark of the Lille porcelain was a crowned dolphin (symbolising the patronage of the Dauphin of France). This mark is found impressed in the paste, painted in under-glaze blue, or in red or gold, over the glaze.

\section{VALENCIENNES.}

A decree of the State Council in 1785 authorised a Sieur Fauquez, and afterwards his brother-in-law, Lamoniary, to establish at Valenciennes a factory of common or fine porcelain, in imitation of that of the Indies, and to produce it during ten years without any local competition, upon condition that the firing was done with coal. Vannier, who came from the works at Lille, became the heart and soul of the enterprise, but the commercial management appears to have been somewhat lax. In 1787 M. Commelin, the Inspector of Porcelain Factories, states that the manufacture is carried on regularly, but that there is little work in the painting-rooms because Fauquez' own workmen compete with the factory by decorating white porcelain pieces on their own account, which are not marked. For this infringement of the rules some of the workpeople were fined as much as 3,000 livres each, and other manufacturers 
in the locality were ordered to obey more strictly the conditions of their licences, which instructed them to mark all their white pieces. The Valenciennes paste is perfect, and very transparent, while the glaze is also of excellent quality, and the decoration carefully executed. In addition to pieces of this high quality, one also finds a coarser variety of porcelain, which was evidently made and decorated with blue in imitation of the cheaper productions of Tournay. A few very good groups in "biscuit" were also made here, but the works was finally closed about 1797. There is every reason to believe that the mark was formed by the letters "L. V." interlaced, the initials signifying "Lamoniary, Valenciennes." The common productions appear to have been marked with the name "Valenciennes," either abbreviated or in full.

\section{CAEN.}

In 1798 there was established, at Caen, a manufactory of earthenware after the English fashion which shortly afterwards produced, by the use of materials from limoges, hard-paste porcelain of very good quality, and this porcelain had a decided vogue until about 1808, when the unfortunate economic situation of France, following on the perpetual warfare of the period, obliged the director, Ducheval, to bring his enterprise to a close. The porcelains of this factory are often decorated with a yellow ground. The ornament and gilding, in the Empire style, were always well-designed and executed, as is shown by the milk-jug preserved in the Victoria and Albert Museum, of which we give a reproduction (see Fig. 44).

The mark of this factory was the word "Caen," printed in on-glaze red in a cartouche or label.

\section{WEST OF FRANCE.}

\section{LAURAGUAIS.}

We have already stated in a previous chapter (see p. 75) that, in 1765, M. Guettard announced the discovery of kaolin near Alençon, and exhibited before the Academy experimental pieces 


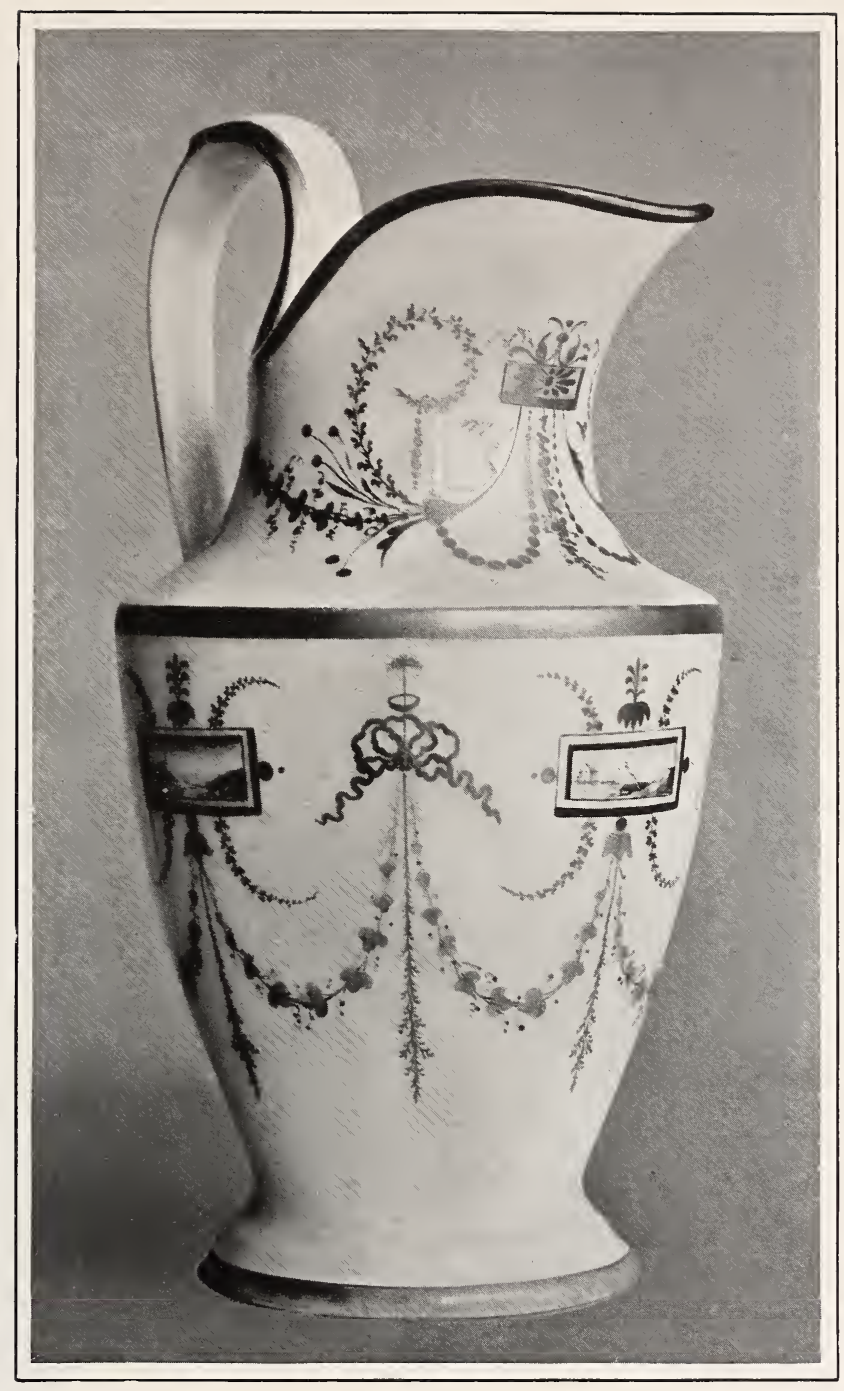

CAIN (Pate dure, XIXrth Century).

Fig. 44 -Milk JUg decorated With PAINTINGS en camaïeu GREY, AND RICH GILDING.

H. $7 \frac{5}{5}$ in. W. $3 \frac{7}{8}$ in.

Victoria and Albert Museum. 

of a brownish hard-paste porcelain. He thus revealed the secret of M. le Comte de Brancas-Lauraguais, who by the aid of Darcet, the celebrated physicist, had made, about 1758, experiments in porcelain from the kaolin and felspar found near Alençon. At the time, the Comte de Brancas-Lauraguais strongly repudiated Guettard's statements, which were, however, perfectly true. The porcelain of Lauraguais was of a coarse, brownish paste at first, and the glaze was full of black pin holes.

The later pieces, in the style of Chelsea porcelain, were decorated in blue. The "biscuit" pieces have a grey tone. The pieces are marked with the letters " $B$ " and " $L$ " interlaced, in under-glaze blue, or, for the "biscuit" pieces inscribed in the paste.*

\section{LIMOGES.}

As the finding of kaolin near Alençon had led to the productions of Lauraguais, so the discovery of kaolin at St. Yrieix stirred up the faïence-makers of Limoges to make hard-paste porcelain there. An edict of 1783 authorised Massié, Fourniera, and Grellet to make hard-paste porcelain with the registered mark "C. D." This factory was acquired in May 1784, by the King of France, to serve as a branch establishment of Sèvres, and the son of M. Grellet was its director until 1788, being succeeded by M. Alluaud, a merchant of Limoges. The idea of a branch establishment of Sèvres does not appear to have been a successful one, so that the works were afterwards sold, and are still in operation for the production of hard-paste porcelain. The pieces made at this factory during the eighteenth century had an ivory-coloured body, and were generally decorated with little flowers, and it should be added that the colouring was usually somewhat dull. In Fig. 45 will be found the reproduction of a typical plate of this manufacture which is now in the museum at Sèvres.

\section{LA SEINIE (NEAR LIMOGES).}

About 1774, the Chatteau of Seinie was transformed into a porcelain-works, with ovens and mills, by a company, the

* The Comte de Brancas-Lauraguais took out an English patent for the manufacture of porcelain in 1766 , but it was never proceeded with.-ED. 
principal promoters of which were the Marquis de Beaupoil de St. Aulaire, the Chevalier Dugareau, and the Comte de la Seinie, and in 1779 they applied for the privilege of selling their products freely throughout the kingdom.

Their principal business, however, appears to have been the preparation of the materials for hard-paste porcelain, and they contributed largely to the success of the small factories at Paris by reducing the price of the porcelain material from sixty livres to about twelve livres a hundredweight. Some manufacturing was, however, conducted here, and the works was continued until 1794. In the earlier years the pieces were extremely translucent, but later on they became less so. The decoration was in the Sèvres style with bouquets of flowers in many colours. The mark consisted of the letters "L. S." either interlaced or written separately.

\section{TOURS.}

Noël Sailly, a faïence-maker of Tours, applied in 1782 for the necessary permission to make porcelain, and the Inspector of Manufactories, Huet de Vaudour, was charged by the government with the necessary supervision of the experiments before they agreed to grant a subsidy. Sailly made some ovensful of ware which came out very imperfect. He died in 1783 , and his son continued his experiments, but we are without any information as to whether this works ever passed beyond the experimental stage.

\section{ORLÉANS.}

We have already described the beautiful soft-paste porcelain of Orléans (see pp. 84-85), but towards 1770 the same manufactory produced hard-paste porcelain. At first these pieces were highly felspathic and, therefore, very vitreous, the decorations consisting of simply-painted flowers. In time the quality improved, and the decorations were also executed much more carefully. The general mark is a simple label (lambel) (see Section on "Marks"), painted in colour or in gold on-glaze. The factory was still in existence as late as 1811, and at that period the mark was a round vignette containing the word "Orléans." 


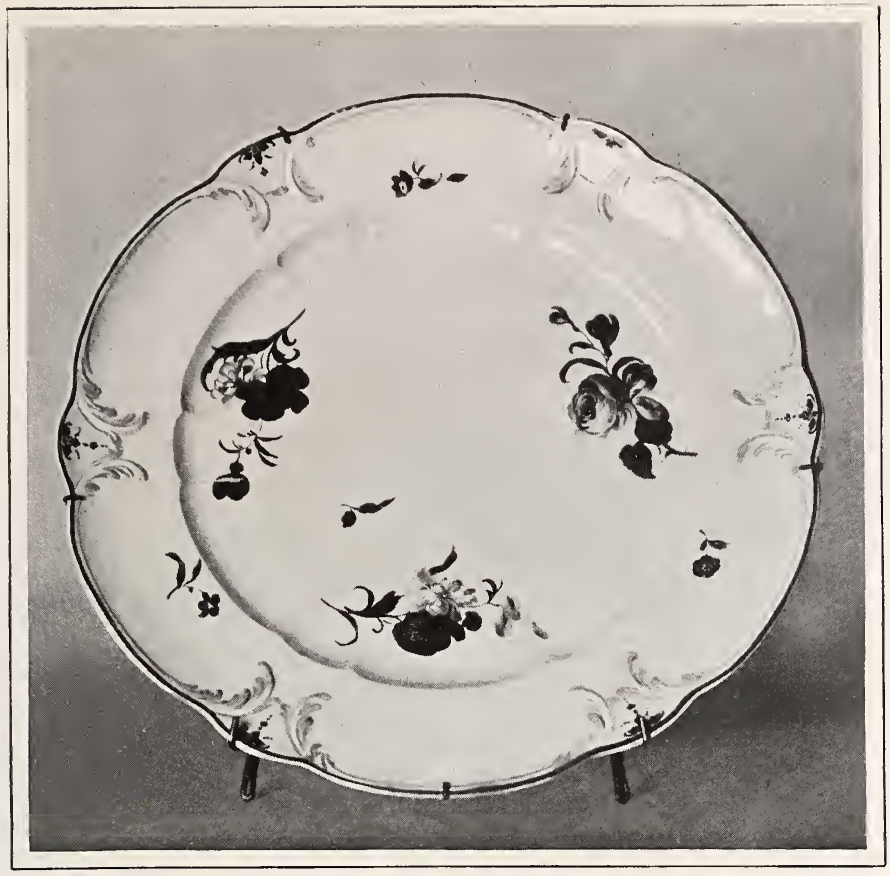

IIMOGES (Pâte dure).

Fig. 45.-PLATE DECORATED WITH FLORAL SPRAYS. PERIOD 1780.

Dia. $95 \mathrm{~s}$ in.

Sèvres Museum.

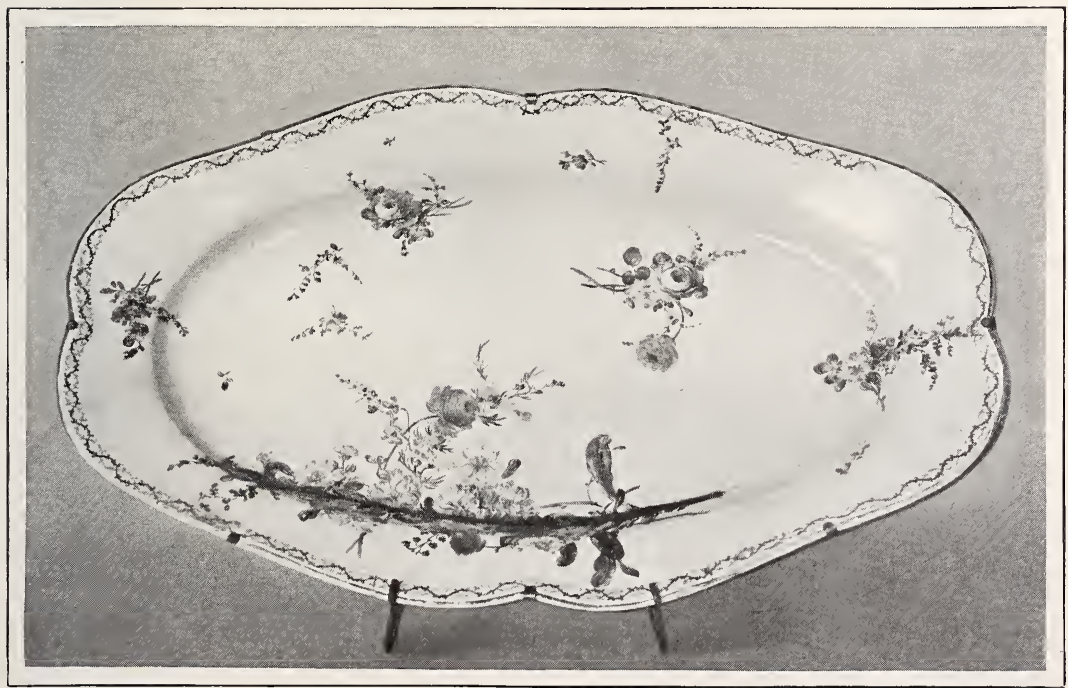

MARSEILIES-FABRIQUE DE ROBERT (Pâte dure).

Fig. 46. - Dish with sprays of Flowers painted

IN COLOURS. PERIOD 1780 .

L. $21 \frac{5}{8}$ in. W. $13 \frac{3}{8}$ in.

Sèvres Museum. 



\section{SOUTH OF FRANCE.}

\section{MARSEILLES.}

Fabrique De SAVy.-In 1765, Savy, the well-known faiencemaker of Marseilles, applied for the privilege of experimenting in the fabrication of hard-paste porcelain. M. Bertin, the minister, granted him this privilege, but without the right to manufacture commercially. We have no exact information as to when Savy undertook the manufacture, but in 1778, when Monsieur, the King's brother (afterwards Louis XVIII.), visited this works they were only making faïence. In 1779 and 1780 the "List of Merchants" describes Savy as "Maker of Faïence and of Porcelain," but as we have no knowledge of any existing pieces from this factory we are driven to the conclusion that Savy's work in porcelain never passed beyond the experimental stage.

FABRIQUe DE RoBERT.-Another of the faïence-makers of Marseilles, J. G. Robert, was already in full work as a manufacturer of porcelain at the time of the visit of Monsieur, for this prince visited his works and admired a vase, remarkable for its form and its modelling, and a complete service which was ordered for England. The pieces of this service and the vase were decorated with different flowers modelled in porcelain, the foliage of which was extremely light and elegant. Robert explained to the prince that he experienced great difficulty in obtaining the necessary kaolinitic minerals for the manufacture of porcelain, and asked that the government might help him in finding suitable porcelain materials in the neighbourhood of Marseilles.

The earlier pieces of Robert's productions are generally of thick and somewhat clumsy form, the glaze being yellowish grey, while the pieces are decorated en camaïeu in a colour the tint of burnt sienna, while the gilding is thin and has largely been removed by use. At a later period the body is lighter and less grey in colour, while the decorations en camaïeu are more carefully executed. The final period of this Marseilles porcelain 
shows a much better technique. The body and glaze are alike white, and the pieces are decorated with skilfully executed flower paintings in the styles of Sèvres or Mennecy.

Rose-colour and blue were very largely used in these decorations, and especially a greenish-blue colour which is both beautiful and characteristic. As an example of the pieces of the period of Robert's manufacture we illustrate a very large oval dish from the museum at Sèvres (see Fig. 46). The general mark on this porcelain is the letter "R.," with or without a dot to indicate the initials "J. R.," and sometimes the initials "F. R." in under-glaze blue.*

\section{PARIS AND ITS ENVIRONS.}

\section{PARIS : FABRIQUE DU GROS CAILLOU.}

In 1762 Jacques-Louis Broilliet asked to register the letters "L. B." as a mark for hard-paste porcelain, and obtained the necessary authorisation; but he appears to have been chiefly concerned in the production of chemical apparatus and crucibles and no porcelain services or pieces of that description are known to have been made during the existence of his works from 1762 to 1769 .

In 1773 Advenir Lamarre applied for an authorisation of the mark "A. D.," but the granting of that authority is the only knowledge we have of his productions. Nevertheless the decree of 1784, which authorised the continuance of certain hard-paste porcelain works, mentions the firm of Veuve Jullien et Bugnau, "au gros Caillou" and it is surmised that they were carrying on the business of Lamarre.

\section{VINCENNES.}

About 1766 Hannong again demanded the right to establish a hard-paste porcelain works, only to find that every species of porcelain production was forbidden to him. In 1767,

* Further information relative to the faïence factories at Marseilles will be found in Mr. Solon's " Old French Faïence." Cassoll \& Co., Ltd., London, 1903. 
however, one Maurin des Aubiez was authorised to establish, in the Château of Vincennes, a manufacture of faïence in the manner of that of Strasburg, and he was afterwards granted the use of the old soft-paste porcelain works, with authority to make faïence and hard-paste porcelain in so far as he did not infringe the privileges of the royal manufactory of Sèvres. Maurin des Aubiez appears to have been either Hannong's pseudonym, or the name of his sleeping partner or associate, as we find PierreAntoine Hannong, in a document dated 1771, describing himself as the director of the Vincennes manufactory. It seems probable, if not quite certain, that profiting by the experience gained in the works belonging to his family, Hannong sought to establish near Paris a manufactory of hard-paste porcelain, but his first efforts cannot have been very successful, for when his creditors became too pressing he stated that many ovensful of ware had been spoilt owing to the defective construction of the ovens. He appears to have left Vincennes in 1772 to take the direction of the works of the Comte d'Artois in the faubourg St. Denis, or St. Lazare.

The pieces attributed to Hannong at Vincennes are extremely felspathic and vitreous. The body is amber-coloured in tone, and not unlike some of the earlier soft-paste porcelains. The decorations, for the most part, are little painted flowers, the violet or rose-coloured shades of which are often faded from being over-fired. The glaze is frequently pitted, and otherwise defective. The general mark is " $\mathrm{H}$." in under-glaze blue, as well as a mark of the letters " $\mathrm{P}$. H." interlaced, in under-glaze blue, which is often attributed to this factory.

We have no further information of the history of the hardpaste porcelain of Vincennes until 1784, when we find that the Sieur Lemaire, manufacturing porcelain at Vincennes, protested against the edicts of 1784 (see p. 97).

When King Louis-Philippe visited the works at Sèvres, some time after 1830, he recalled the fact that while he was still Duc de Chartres, Hannong had helped to create this works at Vincennes under his protection, but the whole history of the hard-paste porcelain of Vincennes is very obscure, and we have 
no information of its continuance after 1786. We are of opinion, however, that certain pieces of very vitreous porcelain, marked in under-glaze blue, with "L. P.," surmounted by a ducal coronet (Louis-Philippe, Duc de Chartres), came from this works.

\section{ETIOLLES.}

In 1786 a porcelain maker named Monnier applied for authority to make soft-paste porcelain at Etiolles, with a registered mark of the letters "MI.P." conjoined. Very few pieces are known proceeding from this works; perhaps the best known being a pomatum pot in tinted paste, with a blue decoration in the St. Cloud style, which is now preserved in the Limoges museum.

At a subsequent period this factory also made a greyish hard-paste porcelain which was not very transparent. The Sèvres Museum possesses a white milk-jug of this type without decoration, which is marked "M. P."

\section{PARIS : FABRIQUE DU COMTE D'ARTOIS.}

This manufactory was situated in the faubourg St. Lazare or the faubourg St. Denis, and was the first which made hardpaste porcelain in Paris on a commercial scale. It was under the patronage of Charles-Philippe d'Artois, the brother of Louis XVI., who afterwards became Charles $X$., and it appears to have been established about 1769, while Pierre-Antoine Hannong became its director in 1772. From the commencement there appears to have been a very large output of pieces, but the business did not prosper owing to the bad habits of Hannong himself. Through the influence of the Marquis d'Osson, one of the proprietors, Barrachin was appointed director about 1775 . It was at this moment that the factory obtained the patronage which gave it its title of "Manufacture du Comte d'Artois," and its prosperity may be said to date from the same period.

Louis-Joseph Bourdon-Desplanches was director of the works in 1782, and succeeded in firing his ovens with coal. An ovenful was fired in presence of the municipal authorities, the chemists of Sèvres, and a number of noted people. 


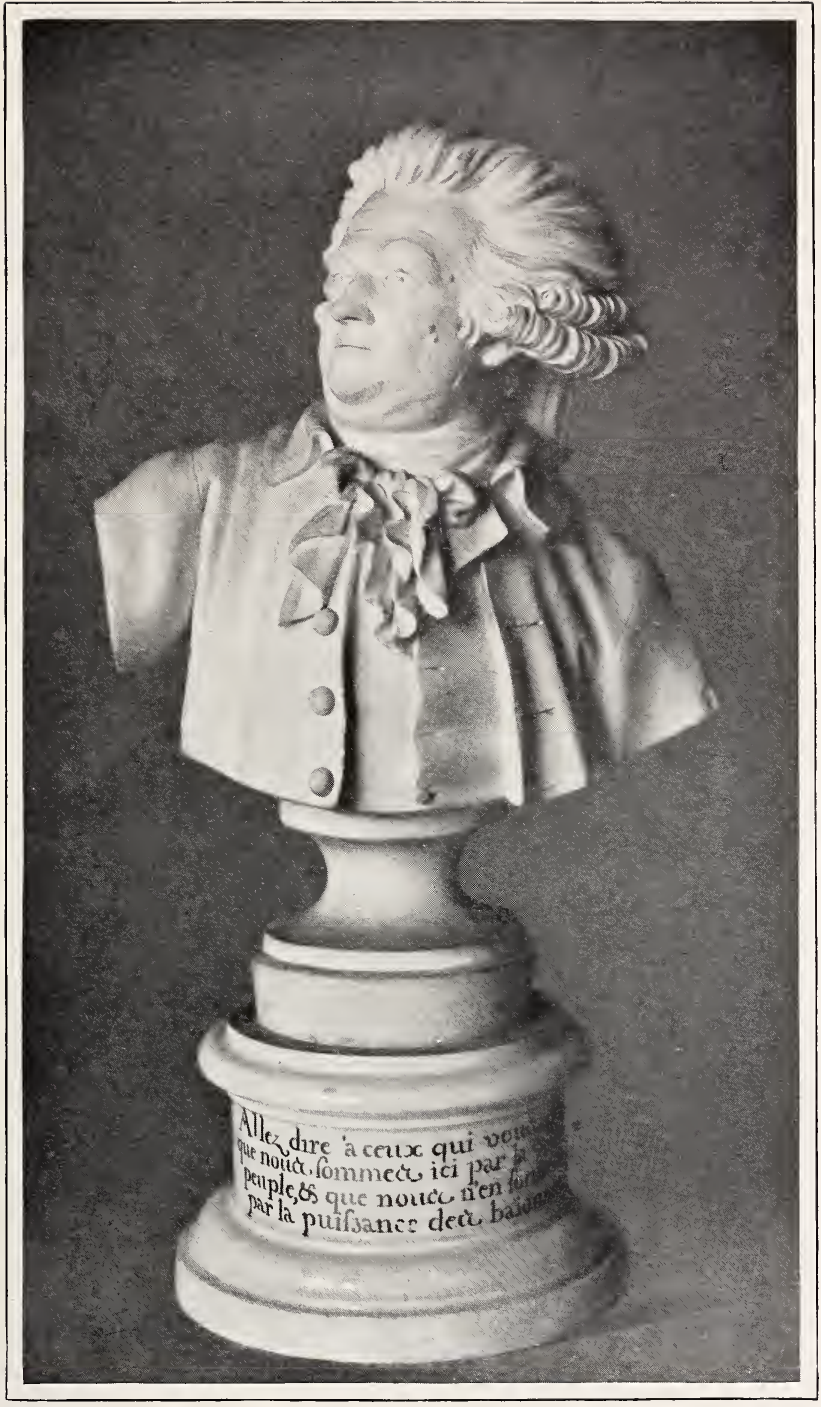

PARIS-FAUBOURG ST. DENIS

(Pâte dure)

Fig. 47.-BUSt OF MIRABEaU. 1789-90.

H. 12 in.

Sèrres Museum. 

There is still in existence a statement, signed by Macquer, Darcet, and other savants, stating that the porcelain pieces, drawn from this oven, were neither cracked, blistered, nor uneven, and that among the 1,140 pieces drawn, there were 782 first-rate pieces, 127 second-rate pieces, 131 third-rate pieces; while 76 pieces needed to be refired, and there were 24 pieces broken. This experiment caused a great sensation at the period. Several large vases were made and offered to the King and to the Comte d'Artois. The vase presented to the King was exhibited for several months at the Château of Versailles; it bore the inscription "Cuit au charbon de terre épuré, dans la manufacture de Monseigneur, Comte d'Artois le 8 Fevrier, 1783." As a result of these experiments Bourdon-Desplanches was granted a subsidy of 3,000 livres.

In order to escape the consequences of the edict of 1784 (see pp. 97-98), the manufactory applied in 1785 for the right to continue the manufacture of busts, "biscuits," and other sculptured pieces, as well as for the right to paint in all colours and to decorate and inlay with gold, on condition that the firing was conducted entirely with coal. M. d'Angivillers, knowing: how much the export of "biscuit" pieces had been developed, and anxious not to discourage such a beautiful industry, finally allowed the decoration in gold so long as it was not used all over the piece, and permitted the production of "biscuit" pieces so long as they did not exceed the height of 18 inches.*

In 1786 Bourdon-Desplanches obtained a further subsidy of 10,000 livres, while the chemist Josse, who was connected with this works, received a subsidy of 400 livres for having discovered a pleasant blue porcelain paste with which all kinds of ornamental pieces might be formed without using gold or other colours. The works continued in full operation until about 1793, when all French industry was completely paralysed, but there seems to have been a revival after the worst period of the Revolution, and we find the works successively under the direction of Huet and Benjamin, and afterwards of Schœlcher, until it was finally closed in 1810.

\footnotetext{
* Decree of January 17, 1787 (see p. 98):
} 
It should be stated that, speaking generally, the productions of this works are of irreproachable quality and execution. Of its fine "biscuit" pieces we give an example in the reproduction of the very remarkable bust of Mirabeau, made about 1790 , which is preserved in the museum at Sèvres. It is not a little piquant to see the manufactory of the Comte d'Artois doing its best to popularise the great men of the Revolution.

The more ordinary productions of the factory during its first period closely resemble the pieces attributed to Hannong at Vincennes, having an extremely vitreous and slightly ambercoloured body, with a very defective glaze. The polychrome flower paintings are characterised by a reddish-violet colour, which is also used to line the borders of dishes and plates. These early pieces bear the mark " $\mathrm{P}$. H." in under-glaze blue.

Under the influence of Bourdon-Desplanches the porcelain quickly became whiter and more milky in tone, and of quite unexceptionable quality; it may, indeed, stand comparison with the contemporary productions of Sèvres. The forms are somewhat bizarre, and in the full Louis XVI. style, while others are directly copied from those of Sèvres. The decorations are generally landscapes or figure-groups painted en camaïeu in a grey colour, but we also find well-painted bouquets in polychrome, and extremely careful gilding.

The "biscuit" pieces were very numerous, and comprised busts of distinguished personages as well as groups and statuettes inspired by those of Sèvres or Niderviller.

During this second period the mark consisted of the letters "C. P." interlaced, or more frequently the capital letters "C. P." surmounted by the crown of a "prince of the blood." The mark was generally enclosed in a vignette and was painted in red or some other enamel colour.

VAUX.

A hard-paste porcelain factory, managed by one Sieur Moreau, was in existence in 1770, at Vaux, near Meulan. It has been stated that this works was founded by Hannong, but of this there is no proof. The body of this porcelain was white, 


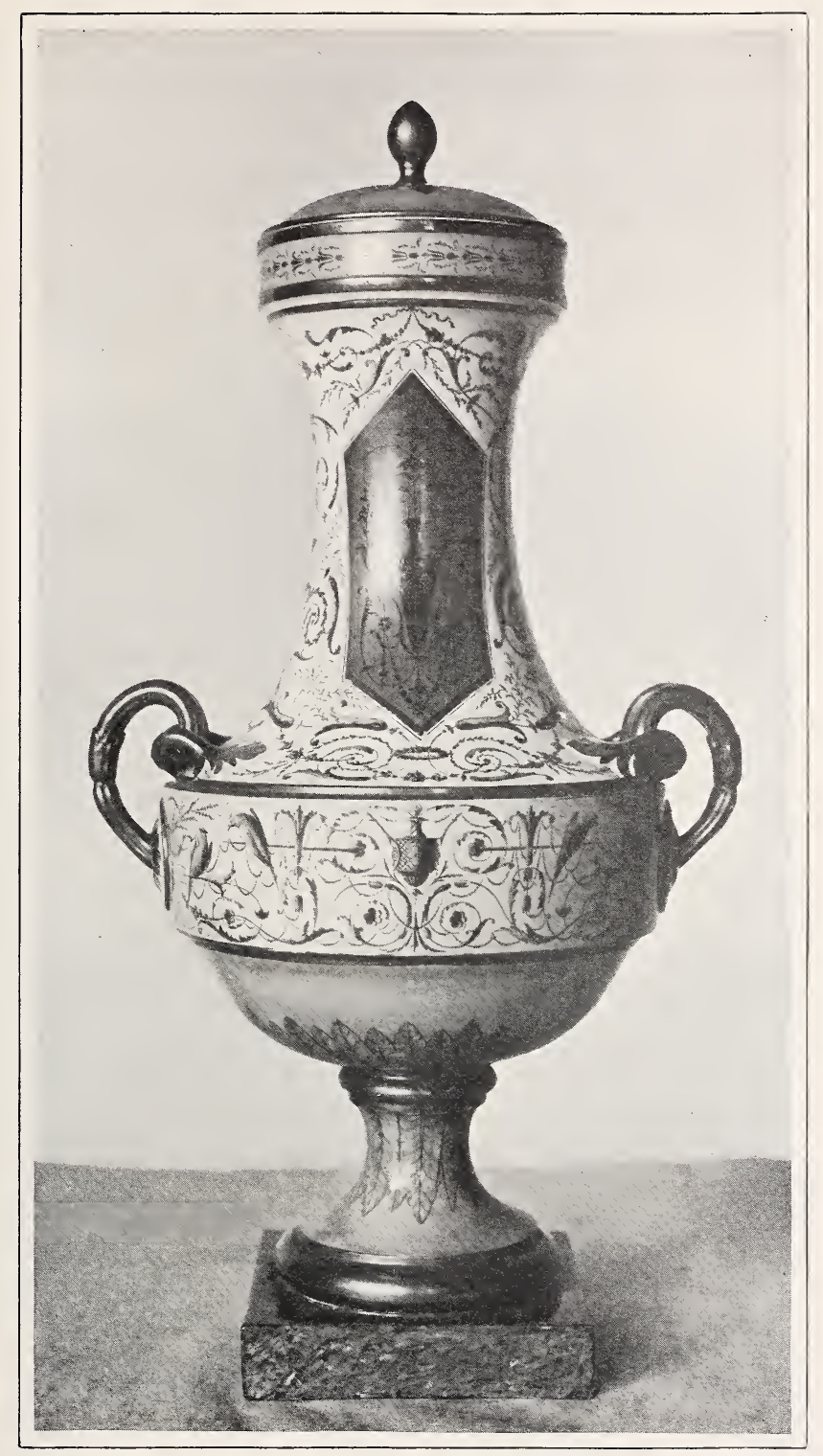

PARIS-FABRIQUE DE LA COURTILIE

Fig. 48.- VASE, PAINTEd AND GILDED. PERIOD 1775.

H. $19 \frac{1}{2}$ in.

Sèrres Museum. 

and the pieces were carefully made, while the gilding and the painting were perfect. The mark consisted of two crossed "V's."

\section{PARIS : FABRIQUE DU FAUBOURG ST. ANTOINE.}

The only knowledge we have of the existence of this factory is an application made in 1773 by one Sieur Morel to be allowed to manufacture porcelain in the faubourg St. Antoine, with the intended mark "M. A. P."

PARIS: FABRIQUE DE LA RUE DE LA ROQUETTE.

This works was founded in 1773 by Souroux, and it remained in his possession until 1784, when Rivet became director, but in a few years it passed into the hands of Olivier, the famous faience-maker. The body of this ware is extremely, vitreous and somewhat amber-coloured, with a very bright glaze. Certain pieces are decorated with gold lines or with little blue flowers. The general mark is an "S." in under-glaze blue.

There was another factory in the rue de la Roquette, of which Vincent Dubois was the owner from 1774 to 1787, known as "Les Trois Levrettes" because a company of archers met in this place; and we are of opinion that the pieces marked in under-glaze blue with two crossed arrows, which are generally attributed to the factory of Locré (see p. 134), really came from this works.

PARIS: FABRIQUE DE LA COURTILLE.

This works was founded in 1773 by Locré at rue Fontaine-auRoi with the avowed intention of producing imitations of German porcelain. The works appears to have produced a large number of pieces, comprising fine show pieces like the large vase with a coloured ground and arabesque ornament, of which we give a reproduction in Fig. 48; and numerous tea, coffee and dinner-services, of a beautiful white, decorated with ornaments and little flowers in the style of the period. We must also mention the beautiful and well-made "biscuit" pieces, of which the accessories were often decorated by vermiform applications of porcelain slip (barbotine). At a 
later date the works produced porcelain of a commoner kind very slightly decorated. Towards the end of the reign of Louis XVI. they also made porcelain painted in imitation of agate, to compete with English pottery (see Fig. 49).

Toward 1784 Ruffinger became associated with Locré, and their works attained so much importance that in 1787 it was classed among the factories which were sufficiently important to be maintained, although they were not granted a definite authorisation.

It should be mentioned that it was in this works, about the year 1790, that the process of "casting" was first applied to the manufacture of pieces of hard-paste porcelain.

The business appears to have come to an end about 1794, probably owing to the troubles of the Revolution. At a later date the manufacture was revived under Pouyat and Ruffinger, but they only produced ordinary commercial porcelain.

The mark of this factory consisted of two crossed torches, evidently an attempt to imitate the crossed swords of Dresden, and this mark should not be confounded with the two crossed arrows mentioned above (see p. 133). Sometimes the "biscuit" pieces bear the same mark, or "Locré à Paris;" or "Fabrique de la Courtille."

PARIS: FABRIQUE DE LA RUE DE REUILLY.

A porcelain-maker named Lassia applied, in 1774 , to be allowed to establish a porcelain works in rue de Reuilly, faubourg St. Antoine, and registered the mark "L." No serious production appears to have taken place, however, until about 1781, when we find Cadet, Guettard, Lalande, and Fontanieu stating that the porcelain vessels of Lassia had great fireresisting qualities. In 1784 this factory was one of those protesting against the royal decree we have already mentioned (see p. 97), and it appears that at the time it was directed by Lassia and Chanou. About 1785 the Marquis d'Aubarède was prepared to advance sufficient capital to introduce the method of firing by coal, but failed to obtain the necessary authority. In 1788 Lassia applied for the exclusive permission to make 


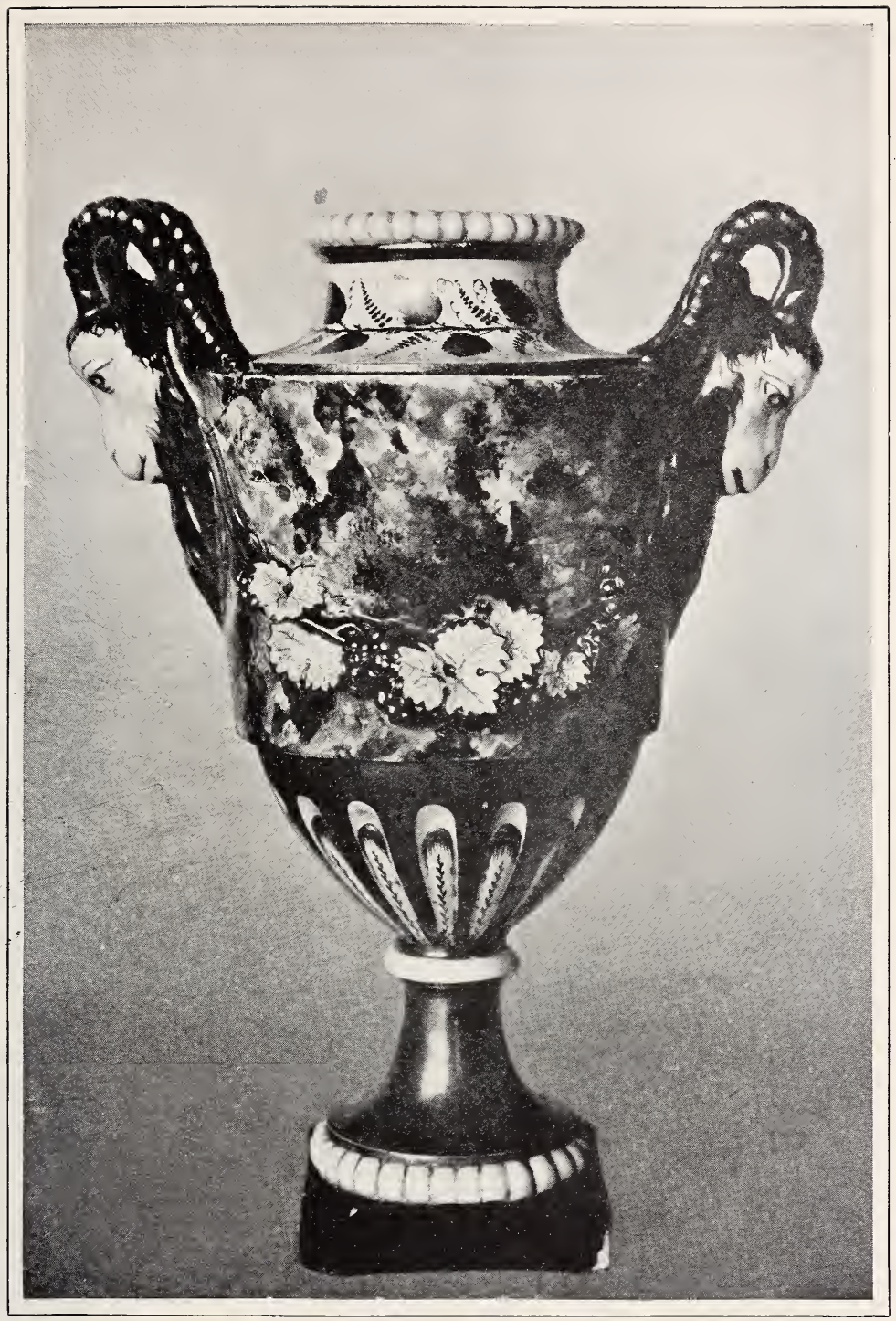

PARIS-FABRIQUE DE IA COURTILIE (Pâte dure).

Fig. 49.-Marbled vase. Period 1775.

H. $7 \frac{1}{2}$ in.

Sèvres Museum. 

stoves and mantel-pieces, but without success. We have no precise information as to when the works was actually discontinued, but we know that it was not in existence in 1800 .

The porcelain of this factory was white, and of good quality. We often find it decorated with grounds in enamel (on-glaze) colour, a yellow ground being quite characteristic. The pieces are frequently decorated with carefully-executed gilding. The mark is the letter "L.," either in blue under-glaze or in gold on the glaze.

In 1784 Chanou separated from Lassia and founded a works of his own, registering the mark "C. H." The pieces of his manufacture are very rare. Such as are known are of careful workmanship, with well-painted designs, and the mark is stamped in red on the glaze.

PARIS: FABRIQUE DE MONSIEUR, A CLIGNANCOURT.

In 1775 Pierre Deruelle notified the authorities at Sèvres of the opening of a porcelain factory at Clignancourt which had been founded about 1771. At the same time he obtained the privilege of placing his establishment under the patronage of Monsieur, the King's eldest brother (afterward Louis XVIII.), hence the title by which the porcelain is generally known.

The works passed into the hands of De Moitte and produced, until after the Revolution, porcelains of extremely good quality, where the paintings and gilding, which are very well executed, decorate a material just as beautiful and white as that of Sèvres itself; in fact this manufactory produced pieces quite comparable with those of Sèvres, in the current styles of the period. The earliest mark was a windmill, doubtless from the fact that windmills abounded in the locality, but after securing the patronage of Monsieur, his initials "L. S. X. (Louis Stanislas Xavier)" were made into one complicated monogram which was generally marked in red on the glaze, while sometimes this mark was surmounted by a princely coronet. Other marks are known, such as the interlaced initials containing a "D." (Deruelle), while a "D." surmounted with a prince's coronet, and finally an "M.," surmounted with the same coronet, in red or 
gold on the glaze, became current marks. An attempt was even made to use the mark of two crossed "L's." as at Sèvres, surmounted by a prince's coronet, but Sèvres immediately stopped this infringement of its mark. It is recorded that a visit of the police in 1779 led to the seizure of many porcelain pieces decorated in the styles which were reserved to Sèvres, and for this Deruelle was fined 3,000 livres, with confiscation of the pieces.

\section{BOISSETTE, NEAR MELUN.}

In 1777 Vermonet, father and son, commenced to manufacture porcelain at an old faïence factory, and obtained the privilege of selling their wares in the region of Melun. This factory appears to have existed about fifteen years, and produced mainly pieces of white porcelain, or pieces decorated with paintings of flowers or bouquets. The general mark is said to be the letter "B."

\section{SAINT-DENIS}

M. Laferté, an old farmer-general, authorised the erection of a works for the manufacture of fine porcelain on his property at Saint-Denis, where certain pieces in white porcelain and in "biscuit," in close imitation of the Sèvres porcelain of the period were produced. The Sèvres museum possesses two "biscuit" pieces, one of which represents Louis XVI. and is signed "Cross 1779," the other M. Le Comte de Provence (afterwards Louis XVIII.), and is marked "Grosse, l'île Saint-Denis, 1780."

\section{PARIS: FABRIQUE DE LA REINE, RUE THIROUX.}

Of all the factories which competed with Sères this is the one which carried the imitation to the greatest point of perfection, but it is a singular commentary on the royal authority of the period to find a rival factory openly patronised by the Queen.

About 1778 André-Marie Lebœuf founded a porcelain works in rue Thiroux which prospered so rapidly that in 1779 Lebœuf was fined 3,000 livres for infringing the privileges of Sèvres 

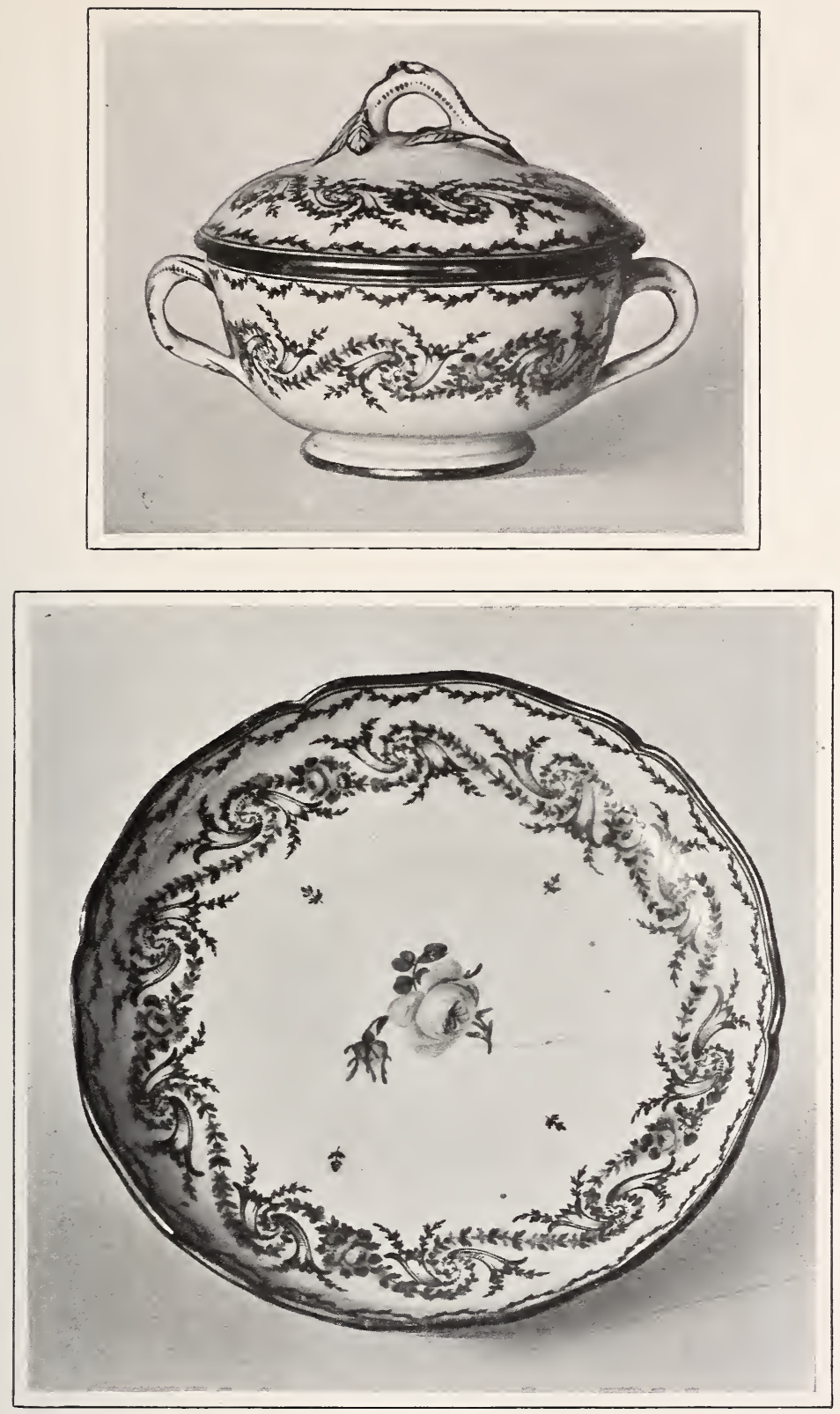

\section{PARIS-RUE THIROUX
(PAte dure).}

Figs. 50 \& 51.-COvered BOWL AND STAND, DECORATED WITH PAINTED ROSES AND WITH GILDING.

H. of basin, $4 \frac{1}{4}$ in. Dia. of stand, $7 \frac{1}{2}$ in. Sères Museum. 



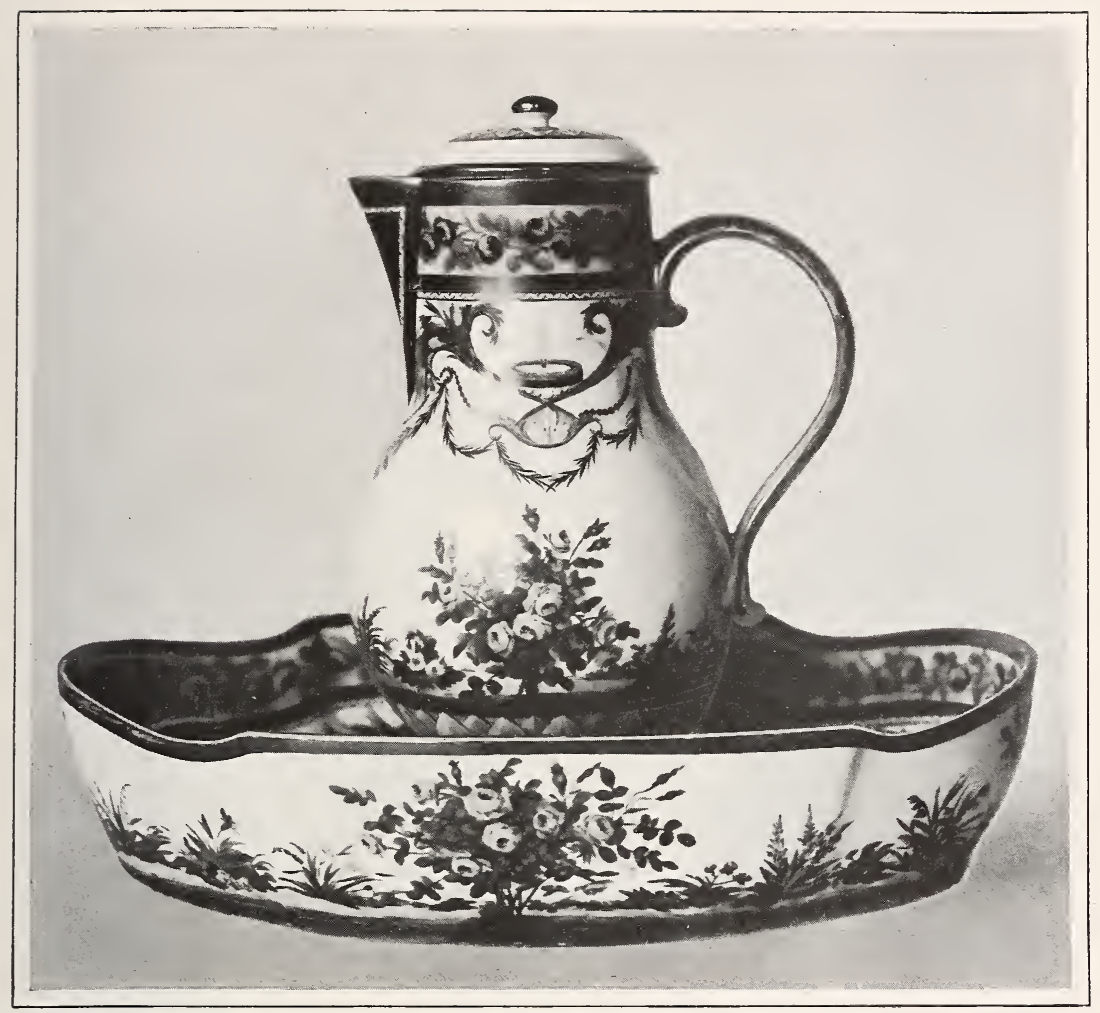

PARIS-RUE THIROUX

(Pate dure)

Fig. 52.-EWER AND BaSIN, WITH

PAINTINGS IN COLOURS.

H. $8 \frac{1}{4}$ in. L. $11 \frac{1}{2}$ in.

Sèrres Museum. 



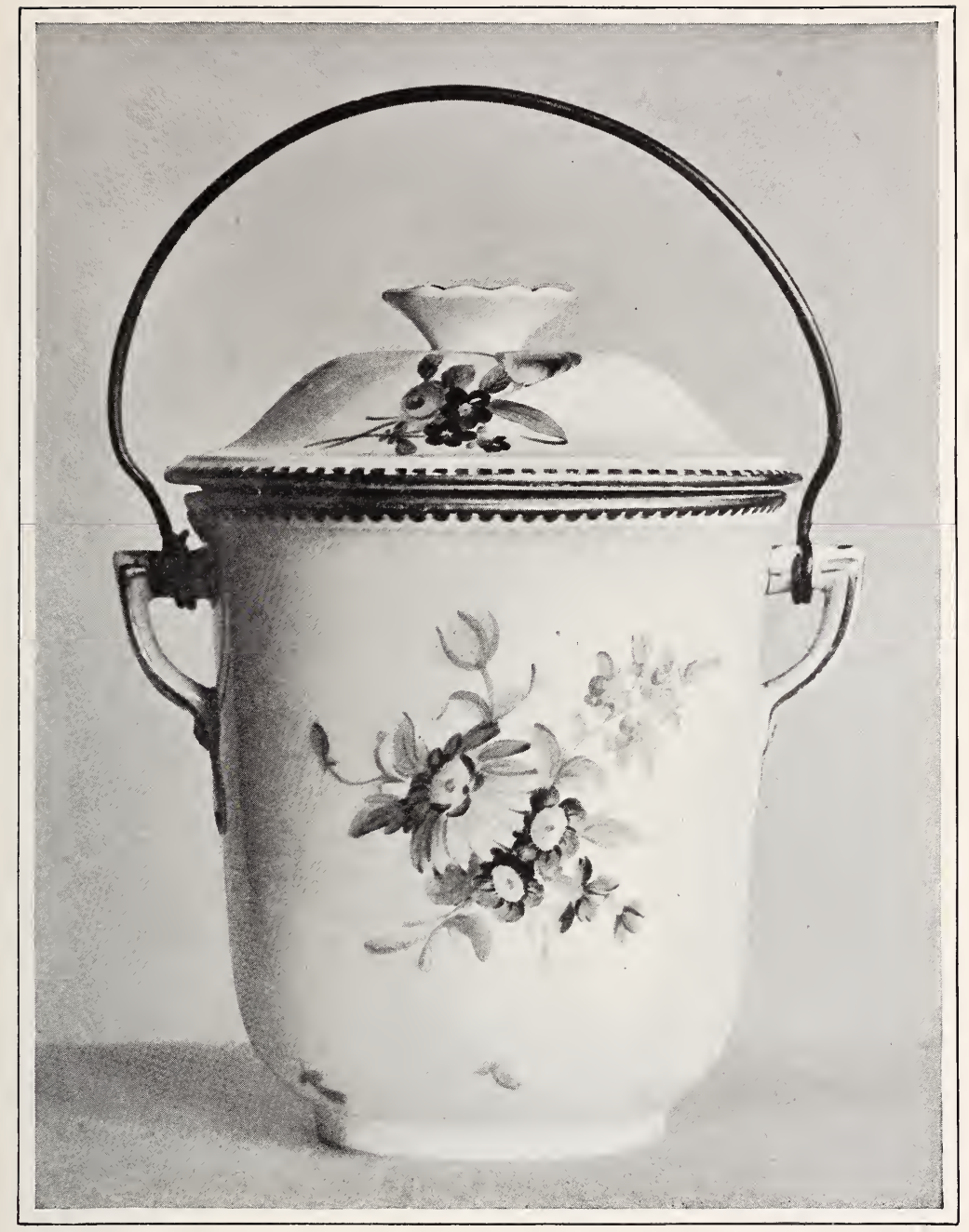

PARIS-RUT Trirooux
(Pâte dure).

Fig. 53. - COvered CREAM-JAR decorated WITH FLOWERS. PERIOD 1780.

H. $5 \frac{1}{4}$ in. W. $4 \frac{1}{2}$ in.

Victoria and Albert Museum. 

by imitating certain of the processes, or decorations, reserved to that factory. An examination of the small ewer and basin reproduced in Fig. 52, and a comparison of these pieces with the similar work of Sèvres (see Fig. 23), will enable us to understand why the director of Sèvres should prevent the market being overrun by such beautiful productions. Apparently it was after this police visitation that Lebœuf put himself under the patronage of Marie-Antoinette, who authorised him to mark his porcelain with her monogram. It was from this factory, too, that the Queen ordered some of the pieces for her laiteries, while she purchased many other pieces as presents for her friends, so that the common name of the productions of this factory became "Porcelaines à la Reine."

There is no evidence that "biscuit" pieces were ever produced, but the glazed and decorated pieces were characterised by the beauty of their body and glaze, and the perfection of their decoration. We have already mentioned the ewer and basin from the museum at Sèvres, and we reproduce in Fig. 53 a covered cream-jar from the Victoria and Albert museum which also shows the taste and style of the pieces.

After the Revolution the works passed into the hands of Guy and Housel, and subsequently into those of Leveillé.

Two marks appear to have been in use, either the letter "A." in under-glaze blue, or the letter "A.," with the Queen's crown over it, in red or in gold. The mark "M. A." interlaced, cannot be attributed to this factory with certainty.

PARIS: FABRIQUE DU DUC D'ANGOULÊME, RUE DE BONDY.

Guerhard and Dihl established this works in 1780, securing the protection of Louis-Antoine, Duc d'Angoulême.

Thanks to the efforts of Dihl, who was an able, scientific man, the productions were soon brought to a high degree of perfection, and it was Dihl who first established a complete palette of colours for the decoration of hard-paste porcelain. All the rich under-glaze grounds ( fonds de grand feu), and all the colours of Sèvres, were successfully produced here. Services with underglaze blue, as well as those with rich gilding and the most 
sumptuous decorations, and fine "biscuit" pieces, all manifest the same high degree of finish.

The productions of this factory were as highly appreciated in England as in France, and they maintained their position during the Revolution and the first Empire. It seems probable that the unceasing efforts of Dihl to develop his productions were due to his ambition to obtain the directorship of Sèvres, which was, however, ultimately secured by Brongniart. But it is certain that the rivalry between these two men was an important factor in the derelopment of the porcelain industry of France at the end of the eighteenth, and the commencement of the nineteenth, century. We find that Dihl had his portrait painted on a porcelain plaque by the painter Ise Guay in 1798, while in 1801 he produced, also on porcelain, a half-length portrait of himself, life-size, painted by Martin Drölling, and this portrait, which is now preserved in the museum at Sèvres, is a real masterpiece of execution in painting on hard-paste porcelain. It is not too much to say that Dihl thus created the industry of portraits on hard-paste porcelain in France.

The mark of this factory consisted of the letters "G. A." interlaced (sometimes in an oval vignette surmounted by a princely coronet), the mark being in red or gold on the glaze. After the Revolution we find the name "Dihl" written with a pencil, or "Guerhard and Dihl, Paris," written in various styles.

\section{PARIS: FABRIQUE DE LA RUE POPINCOURT.}

Lemaire, whom we have already mentioned in connection with the hard-paste porcelain works at Vincennes, founded, about, 1760, a works in the rue des Amandiers, Popincourt, which was bought in 1783 by Nast père, and afterwards belonged to Nast frères. We are not acquainted with any pieces of the earlier years of this factory, but in some collections there are pieces of skilful manufacture bearing the word "Nast" in red. Some "biscuits" of this factory were extremely well executed, and we know a bust of Bonaparte, when he was still a general, which bears the inscription "Buonapart, Manufacture de Porcelaine du citoyen Nast, rue des Amandiers, Popin- 


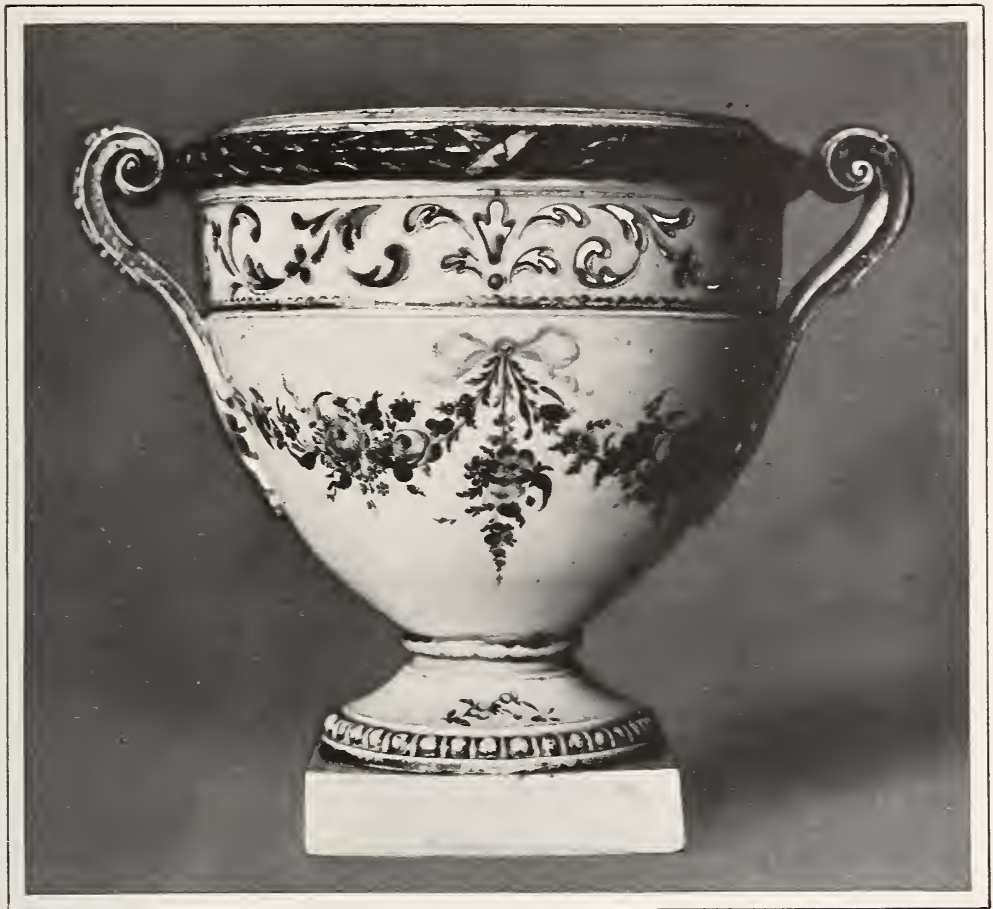

PARIS-FABRIQUE DU DUC D'ORLEANS

(Pate dure).

Fig. 54.-VASE Decorated with Painted FLOWERS, AND ORNAMENTS IN

RELIEF. PERIOD 1786.

H. $12 \frac{1}{2}$ in.

Sèvres Museum. 

court," while the museum at Sèvres possesses a magnificent bust of Hoche, which may be attributed to Boizot, which dates from 1795 .

PARIS: FABRIQUE DU DUC D'ORLÉANS, OR, DU PONT-AUX-CHUUX.

In 1784 one L. Honoré de la Marre de Villiers registered the mark "M. J." for a factory which he was about to establish in the rue des Boulets, faubourg St. Antoine. In 1786 it passed into the hands of J. B. Outrequin de Montarcy and Edme Toulouse, who obtained the patronage of Louis-Philippe-Joseph, Duc d'Orléans, and established theinselves at rue Amelot, Pontaux-Choux. There is little to be said about this factory except that it endured down to about 1806, and that its productions were executed pretty carefully in the general style of the other Parisian factories of the period.

Two marks appear to have been used, one the letters "L. P." interlaced (Louis-Philippe), while the other consisted of the letters "O. M.." (Outrequin Montarcy).

\section{SAINT-BRICE.}

In 1784 Gomon and Croasmen founded at Saint-Brice a porcelain manufactory and applied for the protection of the Dauphin. This patronage was, however, not granted as Lille already possessed that privilege (see p. 122). We have no other information about this factory, and its productions are unknown.

\section{CHOISY.}

It is stated that Clément established a works at Choisy in 1784, which in 1786 belonged to one Lefevre, but we have no knowledge either of the mark or of the productions of this factory.

\section{PARIS: "PRINCE OF WALES" WORKS.}

In 1789 an Englishman, named Potter, established a works in rue de Crussol, which he called the works of the Prince of Wales, where he intended to print* patterns on glass and on

* Potter brought the printing process over from England, where it had been perfected many years earlier.-ED. 
porcelain. In order to obtain the necessary privilege he offered to give a quarter of his profits to the poor. Berthollet and Demarest reported that his method of printing in black was capable of application to porcelain, faïence and earthenware, but gave him no licence, as the authorities had not at this moment decided anything about the continuance of monopolies and privileges. Potter appears to have had a successful business as a manufacturer of earthenware in the English style, but little is known of his porcelain. The museum at Sèvres possesses a cup decorated with butterflies bearing the mark "Potter" in blue, and sometimes we find the mark "Potter à Paris." The mark of the factory of the Comte d'Artois "C.P." with a coronet orer it is sometimes interpreted as indicating "Crussol-Potter," but such a confusion is not admissible.

Potter's productions appear to have been of the cheapest kind, intended for everyday use, so that doubtless most of them disappeared long ago. 


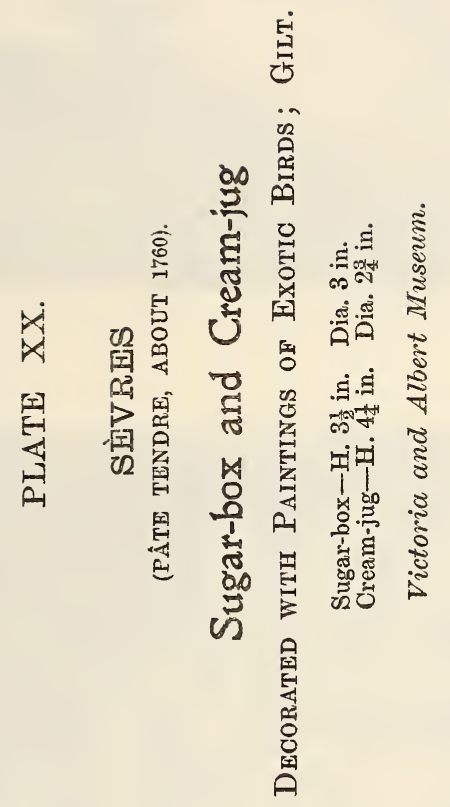




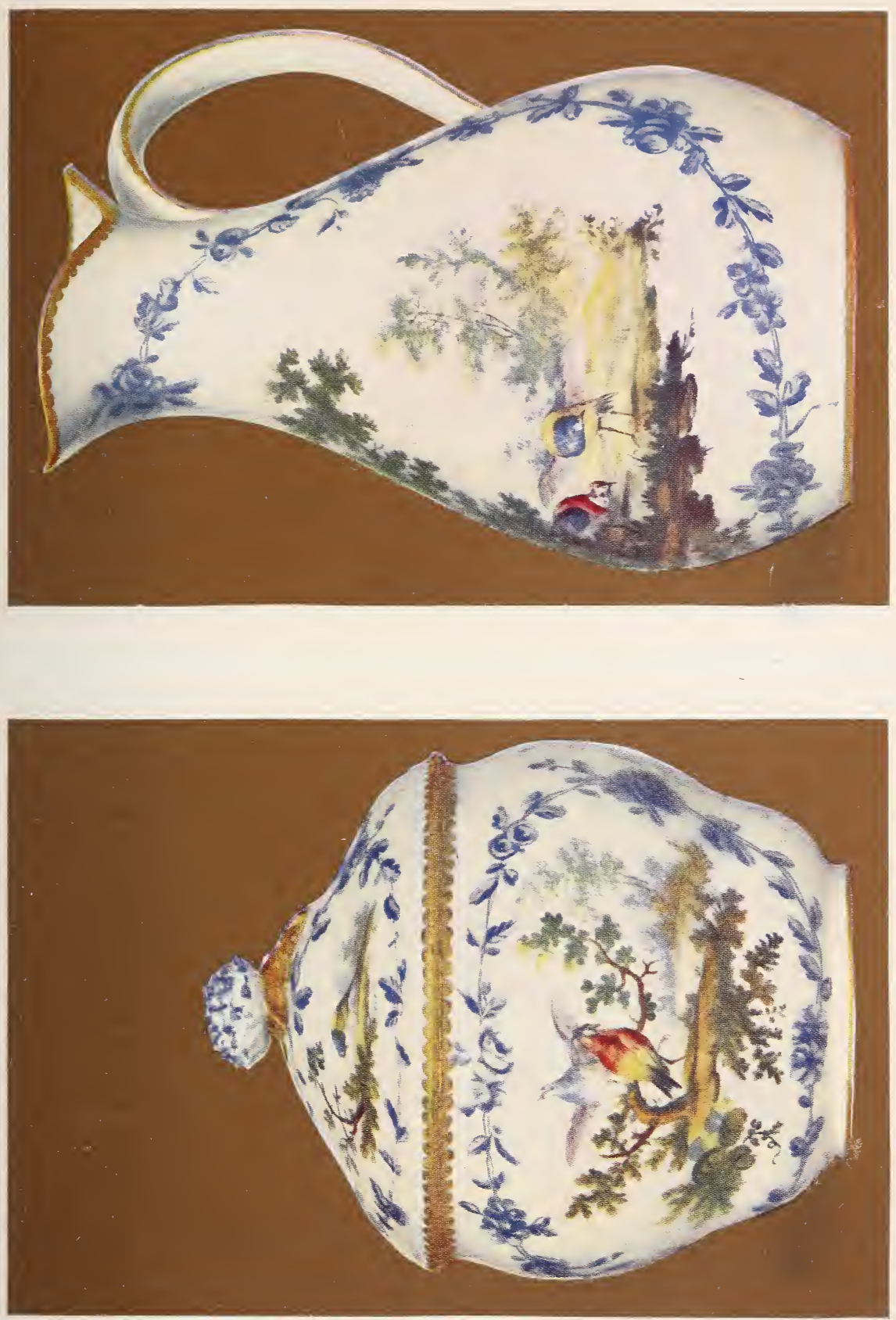



\section{CHAPTER XV.}

SÈVRES DURING THE REVOLUTION.

THE struggle maintained by Sèvres against the development of the private manufacturers of France, to which we have referred in the two preceding chapters, was characteristic of the last years of the Royal régime. What would have happened to the porcelain industry in France if the Revolution had not broken out-whether the private enterprises which had distinguished themselves by the discovery of gilding on hard paste, as well as the method of firing with coal instead of with wood, and by the more perfect development of the palette for hard-paste porcelain, would have triumphed, or Sèvres, which, with its royal subsidies, was able to conduct the most expensive experiments, would have gained the day, no one can now tell.

During this supreme crisis in the nation's history everything went down, and it is now our duty to recount how, in the midst of the most terrible political cataclysm of modern times, Sèvres was able to survive. As early as 1786 , before the Revolution, the sales of Sèvres porcelain became less and less. Not only were the finances of the State absolutely embarrassed, but all private persons of the governing classes were deeply in debt. Yet there was little diminution of the output at Sèvres, and the warehouses became filled with new pieces. Presently the directors, Hettlinger and Regnier, found themselves in a difficult position, because, in the midst of all this profusion of luxurious articles, they had not the wherewithal to pay the salaries and wages. By 1789 the condition of affairs was well-nigh desperate, as it seemed impossible to raise funds to pay the workpeople and to provide the necessary supplies of raw 
materials. It was therefore decided to reduce the output. The immediate result was that the most active and ingenious of the workpeople left the establishment, and, taking advantage of the fact that the edicts defining the monoply of Sèvres were no longer enforced, began to work on their own account or for other manufacturers, thus increasing the existing competition. Those of the staff who remained loyal to the directors, and the principal artists and chemists, fell into idle ways, and the political ferment of the time soon manifested itself in the royal manufactory. Very soon the workpeople were divided into two classes: those of moderate opinions who remained true to the royalist ideas, and those who were inflamed with the new revolutionary propaganda; and these latter soon accused the chiefs of causing, by their negligence and inaction, the ruinous condition into which the affairs of the factory had fallen.

At this moment, some financiers who had won over the noisy portion of the workpeople to their opinions, proposed to buy the manufactory on condition that they paid its debts. A report of the position of affairs was presented to Louis XVI. in 1790, but he indignantly refused to sell the manufactory, and wrote at the bottom of the report the following lines: "I intend to keep Sèvres at my own expense; but I wish the expenditure to be reduced, and so regulated as not to exceed a hundred thousand écus (£12,000); the monthly salaries of the workmen not to exceed 12,000 livres ( $\$ 450$ about), if they cannot be further reduced. The debts shall be paid with the proceeds of the sales, and I will have no more debts incurred, which will be an easy thing, since I supply the monthly money from the funds set apart for the expenses of the royal palaces. I wish an economical plan of administration to be drawn up within a short time. An exact account of the materials supplied, as well of the sales, shall be made, and the money shall be delivered to me after discharging the debts, so that I shall be able to judge from a thorough knowledge of the matter whether I should keep the manufactory, or dispose of it in a more advantageous way than would be possible at present." 


\section{PLATE XXI.}

\section{SÈVRHS}

(PÂTE TENDRE, ABOUT 1758).

\section{Egg-boiler (Coquelle).}

(Described in the Catalogue as BrÛle parfum)-Apple-green Ground with Painted Panels.

Wallace Collection, No. 165, Gallery XVIII. 



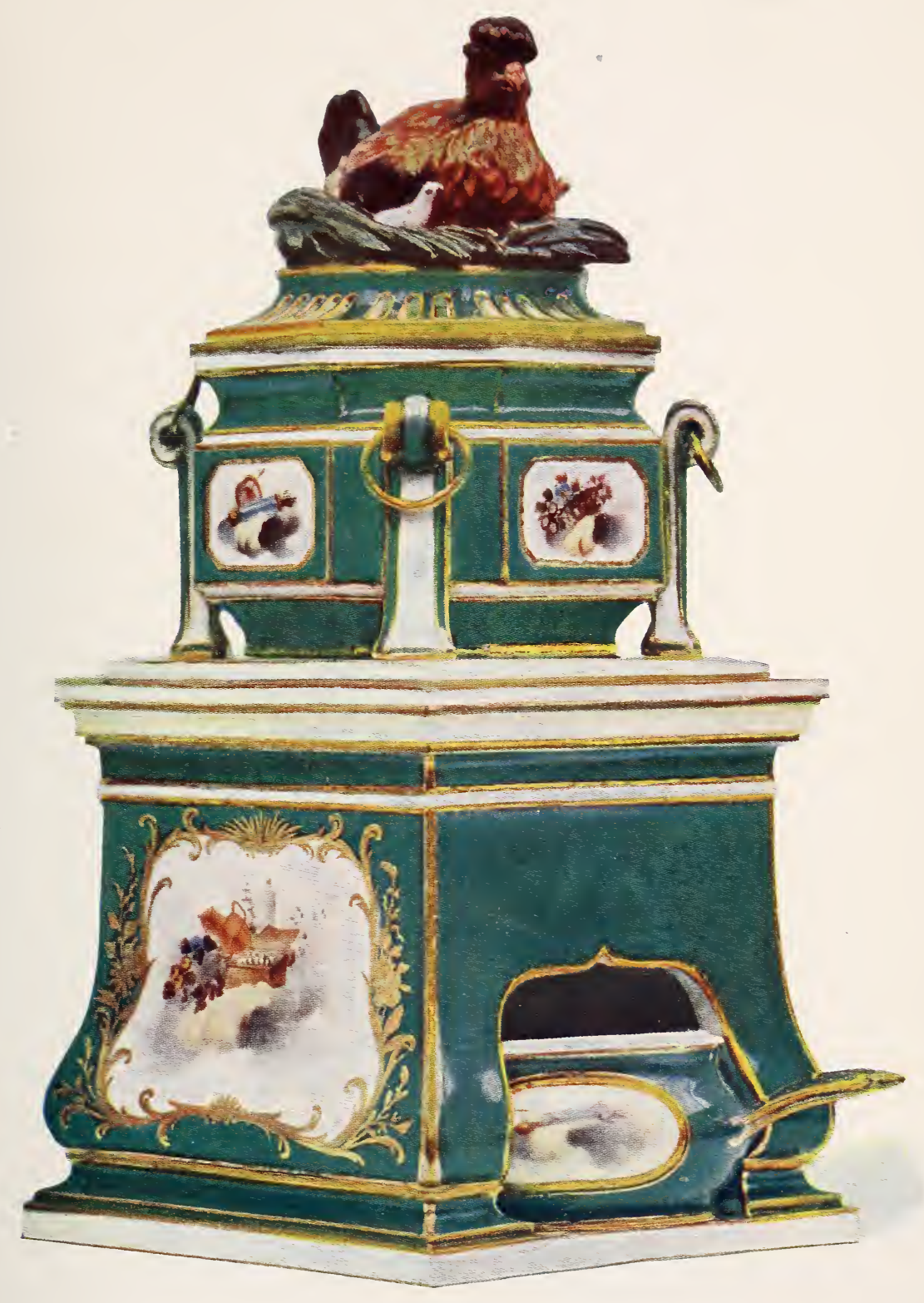



But events moved much more rapidly than the King anticipated, and the next step was taken by the National Assembly, which decided, in 1791, that Sèvres should not be alienated with, or included in, the "National Properties"; while by a decree of May 26th, 1791, Sèvres was comprised among the possessions of the King, and its expenses were chargeable to his civil list. At this moment the value of the works, with its stock in trade and its store of materials, was more than $1,300,000$ livres, while the debts amounted only to the sum of 200,000 livres. It was decided that the debts incurred previous to 1791 should be discharged by selling a portion of the existing stock, while the sale of the fresh products was to provide funds for meeting current expenses. In 1792, Haudry, the overseer of the salt mines of Franche-Comté was appointed commissary, and charged with the administration of Sèvres, under the direction of Roland, the Minister of the Interior ; but Hettlinger and Regnier retained their posts, because Haudry knew nothing of porcelain manufacture. The mission of Haudry, indeed, seems to have been a purely political one, as under his régime the workpeople of Sèvres apparently spent their time in denouncing their chiefs to the Committee of Public Safety. Hettlinger and Regnier had to submit to an unceasing surveillance, while their papers were seized more than once. Hettlinger, who was a Swiss, was suspected of wishing to join the émigrés, and finally he was arrested along with Regnier and several others. At this juncture one of the members of the Convention named Battelier was appointed administrator, and he promptly delegated his authority to J. B. Chanou, one of the artists of the factory, who had denounced the directors. Chanou distinguished himself by thefts, misuse of funds, and embezzlement, and in order to carry out these designs more freely he got Battelier to discharge the cashier, Barrau, on the accusation that he had not collected considerable amounts due from certain noble emigrants, and that he had given a receipt for 15,000 livres' worth of forged assignats. His goods were seized, and he was ordered to get in all the debts of the establishment in a month; a perfectly absurd condition. Battelier decided, also, that all the superior posts of 
the manufactory were in future to be filled by election by the workpeople.

During this time, Hettlinger, being ill, was allowed to leave his prison and keep to his room. He demanded, time after time, to be allowed to leave France, but the Committee of Agriculture, who had just been given the charge of the works at Sèvres, objected to Hettlinger's departure, as his knowledge would be useful in the working of the manufactory. In this extremity they decided to indemnify him, and restore his position to him. Finally, Hettlinger was awarded a salary of 3,500 francs on condition that he did not leave France, and the Committee of Public Safety reorganised the directorate, appointing at first to these posts Hettlinger and Salmon, with whom were associated in succession, Meyer as financial director, Boizot as director of sculpture, Lagrenée as chief painter, and Berthollet as principal chemist, who was some time afterward replaced by Darcet.

With the end of the Reign of Terror, the lives of the chiefs of the departments and the principal artists were no longer in danger, but the financial position was simply deplorable, and the workpeople were literally allowed to starve with hunger. In July, 1793, when the Minister of the Interior issued an order allowing the sale of painted and sculptured pieces, there were no less than 300,000 francs' worth of such products in the warehouses. A contract was signed with one Sieur Empaytay, a merchant of Paris, for exporting 230,706 francs' worth of porcelain, while 33,204 francs' worth of defective pieces of white porcelain were sold to one Sieur Lignereux for sale in Paris itself. Unfortunately these sums were swallowed up by the coffers of the State, which at that time were well-nigh empty, and not one single sou was received by the staff of Sèvres. So bad was the situation of affairs, and so desperate the needs of the staff, that the directors were driven to make advances to the painters and workpeople from their own moneys, or such as they could obtain from their friends. It is said that Hettlinger sold his jewellery to save his workpeople from starvation, and often the casual relief granted by the Govern- 
ment, such as a little meat or bread, formed the only resources of these poor people. In 1795, sacks of flour were distributed by the Government " to keep the workpeople alive," but this flour was so dirty, and so putrid, that it was not even fit to feed animals on.

It is impossible, almost, to realise the terrible condition of Sèrres when, in 1795, while 300,000 francs were owing to the staff, many of them had exhausted every resource, and their landlords and the tax-gatherers seized their last possessions. In their extremity they applied to Talleyrand, the Minister for Foreign Affairs, asking to be paid for the diplomatic presents, which amounted to no less a sum than 290,000 francs. With his usual cynicism Talleyrand answered that "as he had had no open credit at the Treasury for a long time he was unable to give a discount." At this juncture, Perregaux, the banker, advanced the sum of 5,000 francs, and as there was no possibility of repayment, he accepted, in 1798 , porcelain pieces for the amount of his loan and the interest. In the meantime the ordinary sales had come to an end from various causes; the demand in Paris itself for fine pieces had practically ceased; while the sales of the furniture of the Royal palaces, and those of the emigrant nobles, had flooded the English and German markets with the most beautiful and precious pieces from Sèvres, China, and Germany, the accumulation of nearly a century of luxury. At the same time, too, the sale of the imperfect white pieces to Lignereux, which we have just mentioned, enabled all the Parisian decorators fully to satisfy the home demand with pieces bearing the royal monogram.*

By 1799 the petitions of the workpeople to the Government of the day had become still more urgent, but as they obtained no reply, the artists went in a body to interview the minister, François de Neufchâteau, who received them kindly, but could make them no promises. They then approached the Council of the Five Hundred, and finally the Directory, and as a result of

* This accounts for some of the Sèvres pieces, so common in many collections, the paste of which undoubtedly comes from Sèvres, but the marks and decorations of which are forgeries. 
these steps the Council of the Five Hundred finally granted them the sum of 100,000 francs, which was paid.

Again a proposition was made to form a company to take over the affairs of Sèvres from the State for the sum of 500,000 francs, but the offer was most energetically opposed. It should be noticed that the successive governments of the revolutionary period never tried to suppress the Sèvres manufactory. They limited its productions and the number of the workpeople when financial affairs were in their most critical condition, but there always seems to have been an idea that ultimately the establishment might have a great influence on the revival of the porcelain industry, and it was merely left to starve. That it once again reached a condition of prosperity was largely due to the nomination of Brongniart as director of the works in 1800 , and the subsequent protection accorded to it by Napoleon.

After having been influenced by three charming women: La Pompadour, La Dubarry, and Marie-Antoinette, the manufactory of Sèvres found, during the revolutionary period, no influential guides in the matter of taste or art. They repeated over and over again the shapes and the decorations of the time of Louis XVI. Monograms formed in tiny flowers, or initials composed of roses or forget-me-nots, decorated the cups which were used as birthday presents; while subsequently we see the appearance of oval or rectangular medallions, filled with painting, on vases which are more and more based upon Greek or Roman models.

It was necessary to sacrifice everything to politics, and "good citizens" required cups and plates on which the fasces of lictors and tricolour cockades alternate with Phrygian caps and the initials of the King; while at a later period tricoloured ribbons, as the sole ornamental device, show the changes of the political régime. (See Figs. 55 and 56.) Everything that was formerly gracious and beautiful became solemn, and even dull, with the badly revived, ill-understood passion for the "Antique." No materials could have been more unfitted for such a hybrid style than the porcelains of Sèvres, whether of soft- or hard-paste. The worst was to come, however, when the Convention itself ordered what was meant to be an imposing memorial of the Republic. 


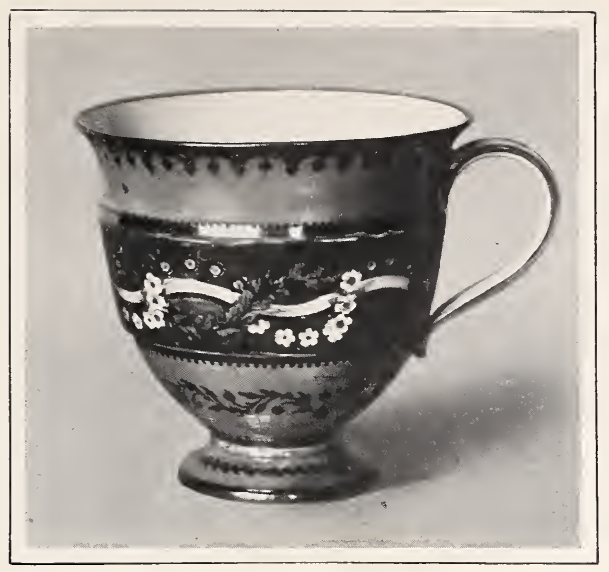

SÈvRES (Pâte tendre).

Fig. 55.-CUP DECORATED With TRICOLOUR RIBANDS. PERIOD 1793.

H. $3 \frac{1}{8}$ in.

Sèrres Museum.

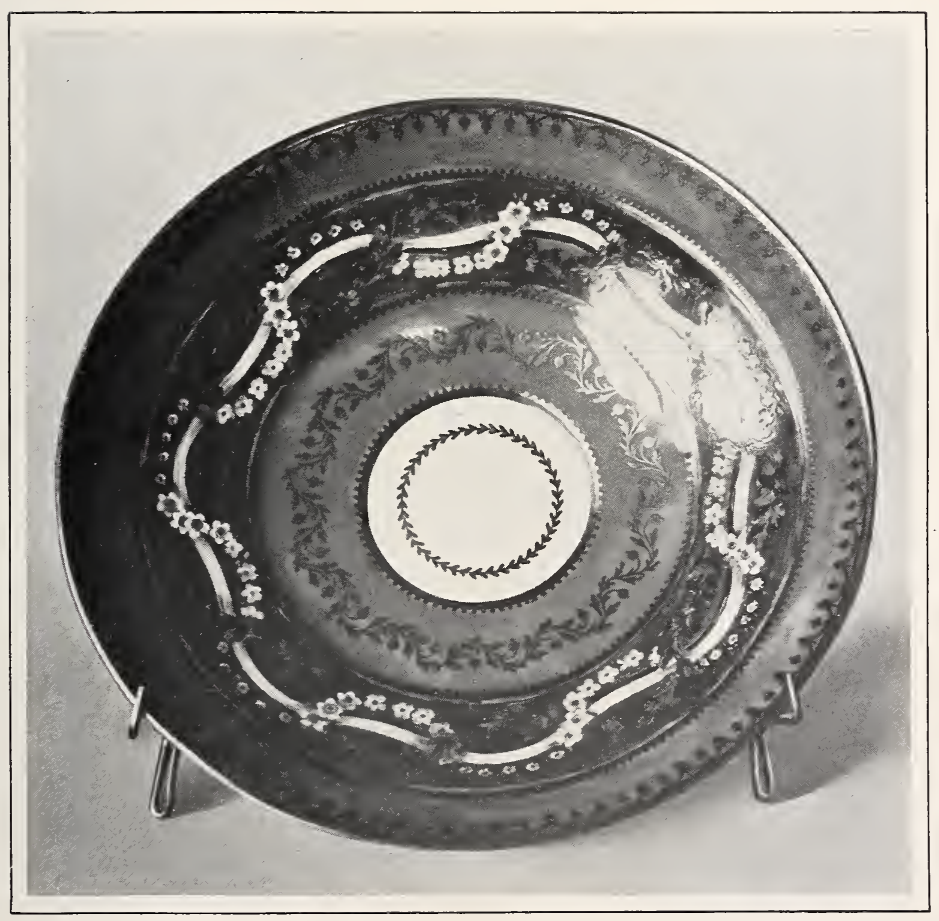

Sk̀vRES (Pâte tendre).

Fig. 56.- Saucer decorated with tricolour RIBANDS. PERIOD 1793.

Dia. $6 \frac{1}{4}$ in.

Sèvres Museum. 

The description of this trophy, which is too long to quote in full, is still preserved among the National Archives. It must suffice to say that the principal group was to represent on the front "Despotism thrown from its pedestal, and carrying down the nobility in its fall." "Despotism" was to be typified by a figure with lean limbs, and with a great head and belly, and its face was to be covered with a mantle, so as to cloak its deformities. Above this group were to be "Truth" and "Liberty," while a group representing the men of the Fourteenth of July, was to be shown, attempting to overthrow the pedestal of "Despotism," with levers and pickaxes. This was to be carried on a square pedestal, round which eighty shields, each bearing the name of a department, were to be suspended by garlands of oak leaves. This porcelain piece was to be supported by a pedestal with truncated angles, made in black wood or mahogany (evidently too difficult of execution in porcelain), on each side of which were to be inlaid bas-reliefs of porcelain representing the most remarkable incidents of the Revolution. Finally, a still larger square wooden plinth was to support the whole, on the four corners of which decorated porcelain vases were to serve as inkstands, while between the vases, long porcelain trays must be provided for the pens and pen-knives. We may imagine, and sympathise with, the feelings of the directors and artists of Sèvres when they received such an extraordinary commission, which, fortunately, was never executed.

Little soft-paste porcelain appears to have been made as for the most part, those in power contented themselves with decorating the large stock of white pieces already in the warehouses. The hard-paste porcelain of the period was also of inferior production; the pieces are often tawny, badly fired, and badly glazed, while the colours are by no means perfect.

In the early part of the period, busts of "Brutus," "Diderot," and "Voltaire" were made, and especially the famous one of "Jean-Jacques Rousseau" as a Roman; afterwards the busts of "Danton," "Pétion," "Marat," and "Robespierre," appeared in their turn. A decree of 1795 ordered the production of busts of two famous children of the Revolution, "Bara" and 
"Viala." The moulds of these works, which have been preserved at Sèvres, have evidently been used for the manufacture of a considerable number of pieces. At a later date, the rictorious generals of the revolutionary armies had the signal honour of having their busts executed in "biscuit," Boizot modelling the busts of "Joubert" and "Marceau," the medallion of "Hoche," and finally the bust of Bonaparte. Long before the coup d'état the Directory ordered Sèvres to send to the members of the Executive Committee, and to the "citoyenne Bonaparte," busts of the victorious general. The order goes on to say that it is the duty of this national establishment to reproduce, in a manner both useful and agreeable, the features of a citizen who has done the Republic such great services.

It should be remarked that, in keeping with the philosophic tendencies of the period, certain of the earlier groups, such as those illustrating the history of Telemachus, were also reproduced.

Finally, one result of the expedition to Egypt was the creation of a so-called Egyptian style, which is so very ugly that we cannot regret its short life.

It has already been mentioned that Talleyrand continued the custom of sending Sèvres porcelain as diplomatic presents. Even the Committee of Public Safety offered to M. d'Haugwitz, the Prussian ambassador, a service designed by the architect Masson, and decorated with arabesques taken from Raphael's frescoes. They also offered to the minister of HesseCassel porcelain pieces worth 24,000 francs, and 36,000 francs' worth to the Prince de la Paix, the Spanish ambassador. They likewise gave porcelain pieces to various ministers of the Cisalpine Republic, such as Visconti, Serbelloni, and Rangone, as well as to M. de Spinola, the Minister of the Republic of Genoa.

To end the history of this unhappy period, we may say that during the years 1789 to 1792 , the mark consisted of the two "L's.," with the date marks "L. L.," “M. M.," "N. N.," "O. O." In the period 1792 to 1800 , the mark of the current year was omitted, and we find instead of the interlaced "L's.," the words "Sèvres " or "Seve," either above or below the interlaced letters "R. F." (République Française). 
PLATE XXII.

\section{SìVRES}

(PÂTE TENDRE, ABOUT 1766).

\section{Ovoíd Vase,}

Decorated with Paintings of Mrthological Subjects; Ground OF BLEU-DE-ROI.

H. 18 in. Dia. $6 \frac{1}{4}$ in.

Victoria and Albert Museum.

(Jones Bequest.) 



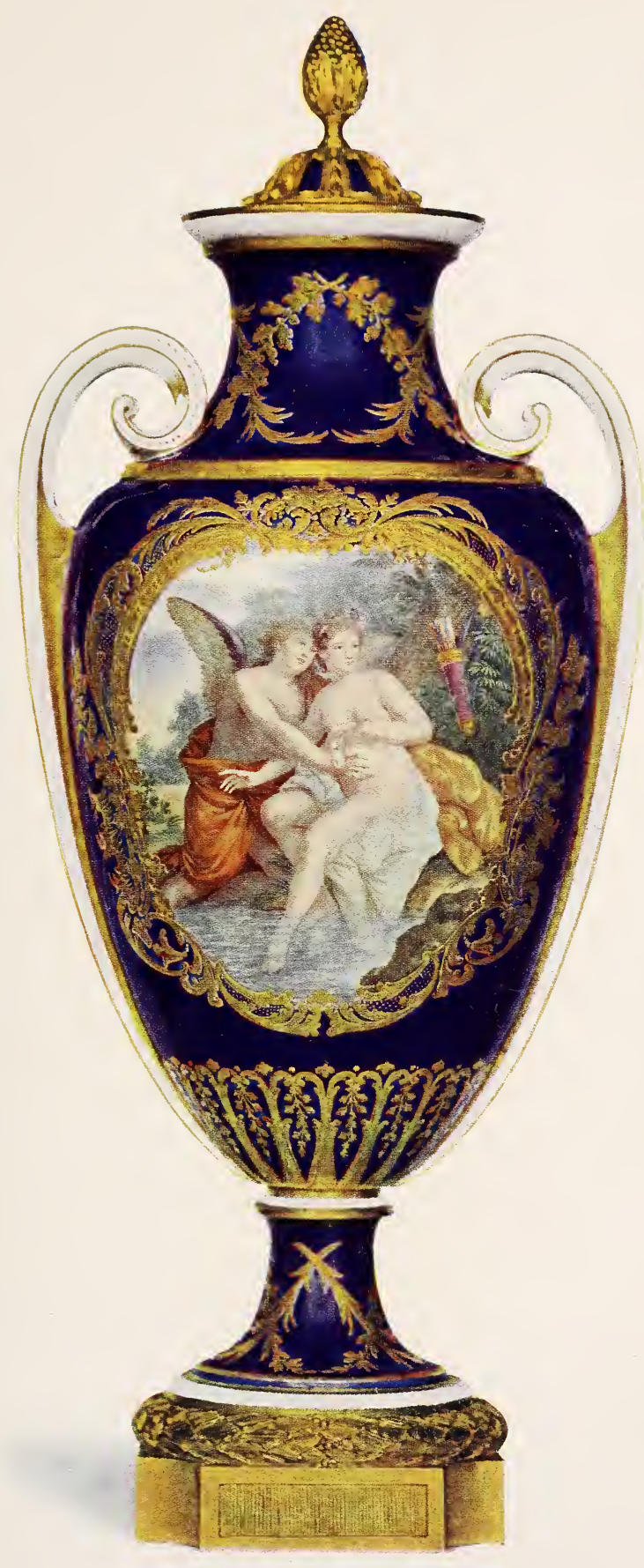





\section{CHAPTER XVI.}

SÈVRES UNDER THE DIRECTION OF ALEXANDRE BRONGNIART.

IN the previous chapter we have seen the deplorable condition to which the royal manufactory of Sèvres was reduced during the tempestuous period of the Revolution. We have now to consider, briefly, how its position was restored, in the first half of the nineteenth century, and how, under the control of the distinguished scientist, Alexandre Brongniart, it continued its labours under the First Empire and the Restoration.

Brongniart was primarily a scientific man. He was by training a mining engineer and a professor of natural history, when at the age of thirty he was appointed, on the recommendation of Berthollet, to be director of Sèvres. For this post there were many rival candidates, the chief of whom was Dihl, the director: of the factory of the Duc d'Angoulême (see p. 138). Considering the monumental labours of Brongniart at Sèvres, his enthusiasm, his honesty, and the influence of his methodical mind, we cannot but think that in many respects the choice was a wise one. His first efforts were directed to the re-establishment of the works and the staff on a proper footing, and with this aim he suppressed the sinecures and checked the abuses that had resulted from the disorganisation of the previous decade. $\mathrm{He}$ replaced day work by piece work, and apportioned apprentices among all the skilled workpeople; while he also retained the services of Boizot, the sculptor-whose fertile and subtle genius we have already mentioned-of the painter, Lagrenée, and of the flower painter, Van Spaendonck. One of his earliest difficulties was the financial condition of the works, which had been 
rendered still more deplorable by the dishonesty of an agent-Lemercier-who was sent out to Russia to dispose of some 92,000 francs' worth of porcelain and who only remitted about 30,000 francs. In 1801, however, the government granted a regular subsidy to Sèvres which afforded a little breathing time, so that the works managed to exist until 1806, when Napoleon decided that Sèvres, along with the Gobelins tapestry works, might be instrumental in recording and diffusing his glories.

Before we speak of the productions of Sèrres under the various governments from 1800 to 1848 it would be as well to recount the successive improvements due to the labours of Brongniart and the group of able assistants he gathered round him. As we have said Brongniart was primarily a scientific man, and his own inclinations were strongly in favour of all those processes which could be regulated so as to lead to certainty of manufacture. It is probably to this fact that we must attribute his decision to abandon that most distinctively French product, the soft-paste porcelain of Sèvres, and his sustained efforts to produce a hard-paste porcelain which left nothing to be desired from the purely scientific point of view. By the aid of a staff of clever chemists, directed successively by such eminent men as Laurent, Malaguti, and Salvétat, all the known European clays, kaolins, and other materials, as well as the bodies and glazes of ancient pottery of every kind, were systematically analysed; while with the help of able practical men like Régnier, the methods of manufacture were also improved in the same direction. It should likewise be mentioned that in 1812 Brongniart was enabled, by the interposition of Napoleon, to visit the famous porcelain works at Meissen; the King of Saxony being obliged to free Steinauer, its director, from his oath of secrecy so that Brongniart might learn all the jealously guarded secrets of the great rival establishment.

All these investigations, and the scientific temper of the period, led to something like a revolution in the nature of Sèvres porcelain. We have already said that Brongniart abandoned the manufacture of the famous old soft-paste, and every effort was made to bring the hard-paste porcelain into 
strict analogy with Chinese porcelain of the hardest type. The hard-paste porcelain first produced at Sèvres, down to 1800, had a calcareous glaze which permitted the use of a fairly wide range of colours as well as of enamels in relief, but in the hands of Brongniart and his chemists the porcelain became harder, the calcareous glaze being replaced by one made from a natural pegmatite (China stone) found at St. Yrieix, which needed a much harder fire to vitrify it. This type of hard-paste porcelain, which is still in use for table-services and work of that class, is difficult to decorate with under-glaze colours (au grand feu), so that the only colours available were the dark or light blue grounds having a basis of oxide of cobalt, the tortoiseshell grounds already mentioned (see p. 106), and the chrome-green grounds rendered possible by Vauquelin's investigations of the oxides of chromium. The difficulties of obtaining brilliant and glossy on-glaze painting (au feu de moufle) were also largely increased, but by the assistance of such chemists as Bunel and Salvétat these difficulties were gradually overcome, and colours were obtained which allowed the reproduction of the most elaborate paintings on hard-paste porcelain. Gold was also used in the most lavish manner, often with dull effects, or with patterns burnished in the fired metal; while decorations in silver and platinum were also largely introduced.

The results of these systematic investigations were finally, incorporated in Brongniart's monumental work, the "Traité des Arts Céramiques," published in 1844, which became not merely the text-book of every potter, but remains a compendium of all the technical ceramic knowledge of that period.

In this connection, too, we must mention the foundation of the museum at Sèvres, due to the enlightened collaboration of M. Riocreux; which was the first, as it still remains the finest collection of pottery from the historical-technical point of view.* Although we have drawn attention to the scientific

* From our point of view the knowledge of English pottery displayed by Brongniart and the collections of English pottery and porcelain preserved in the museum at Sèvres leave much to be desired.-ED. 
influences at work at Sèvres it would not be fair to attribute to this cause alone the want of artistic feeling displayed throughout the period. Many causes contributed to this end, and we are compelled to realise that throughout Europe the first half of the nineteenth century was largely a period of artistic sterility, while the grandiose ideas of the first Empire and of the Restoration in France impressed a special character of their own on the porcelain of Sèvres. In order to describe these in due sequence we must now refer to the historical development of Sèvres under the various governments of the half century which almost coincided with Brongniart's tenure of office.

When Napoleon decided to foster the works at Sèvres he appointed a commission consisting of some of his officials and of the chief manufacturers of Paris. The officials desired to restore to Sèvres the powers which had been granted by the royal edict of 1787 (see p. 98), while the Paris manufacturers, for their part, were anxious to maintain their privilege of making porcelain pieces which could be decorated either on their works or by painters working in their own rooms (chambrelans). Napoleon, however, seems to have considered the question of porcelain manufacture from the national point of view, and, seeing that the export trade in French porcelain was steadily growing, he finally decided that the industry should be freed from every restriction, while at Sèvres the manufacture should be carried to the highest pitch of perfection, so that, from 1806, we find Napoleon and his court giving much attention to the development of Sèvres, and paying frequent visits to the manufactory.

We may realise what the ideas of the period were when we remember that Brongniart proposed to make a magnificent vase, one metre high, decorated with subjects symbolising the conquest of Germany, in a series of allegorical designs in black and red in the Etruscan style, for which he wished sketches to be taken at the seat of war, so that he might preserve on vases the memory of the glorious events of that epoch. Very soon all the resources of the establishment appear to have been directed to the production of pieces which 


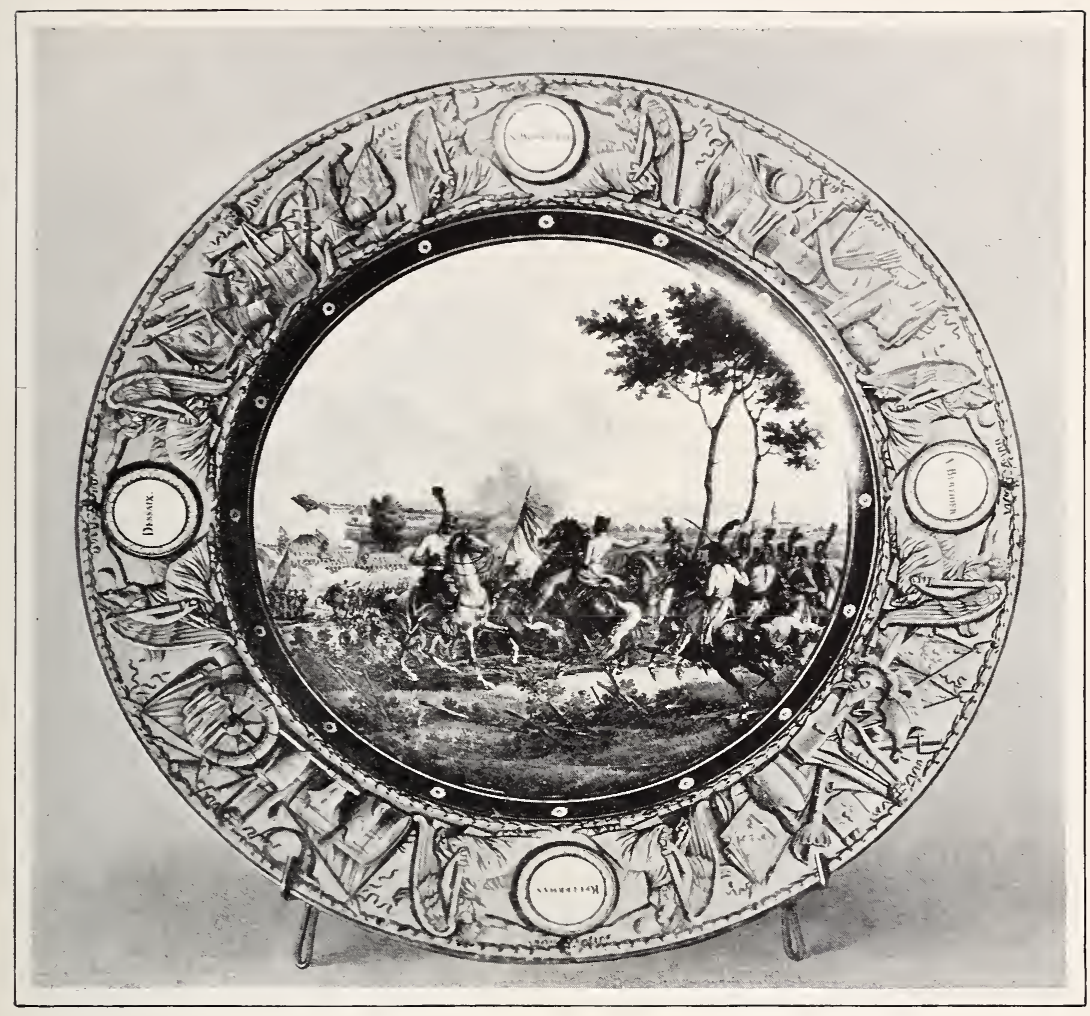

Sz̀vress (Pâte dure).

Fig. 57.-Plate : subject, "the battle of marengo," BY SWEEBACH. PERIOD 1802.

Dia. $9 \frac{1}{4}$ in.

Sèrres Museum. 

were no longer "decorated," but were absolutely covered with painting. The painting invaded everything, both the entire body of the vases and the whole ground of cups, saucers, and plates, so that, what with the painting and the gilding, it is hardly possible to discern the nature of the material beneath. A good example of this kind of production will be found in the reproduction of a plate decorated by Swebach in commemoration of the battle of Marengo (see Fig. 57), the border being decorated by Déparais after designs by the architect Percier. This plate was given to the Empress Josephine on Floréal 23rd, in the year XII. (Nay 12th, 1804). It was afterwards deposited in the palace of St. Cloud, but was evidently stolen during the occupation of 1815, as the plate was returned to Napoleon III. by an Englishman on the 15th May, 1853, when it was deposited in the museum at Sèvres.

The influence of the painter David, and afterwards of the architect Percier, which led to the production of vases and other pieces covered with these elaborately painted scenes, must be looked upon as a most unfortunate thing for the porcelain of Sèvres.

During the half-century we find Clodion, Boizot, Chaudet, Régnier, Bosio, Boquet, and Klagmann successively employed in modelling the shapes and the sculptured ornaments, while Iaffitte, Heim, Bergeret, Isabey, Drölling, Swebach, Leguay, Fragonard, Redoutté, Sinsson, Boullemier, Madame Jacquotot, Béranger, Constantin, Philippine, Jacobber, Schilt père, Moriot, and Chenavard, made the cartoons and executed the painting. The famous Thomire cast and chiselled the bronze mountings during the period of the First Empire.

All the Royal palaces were empty, and it was necessary to refurnish them completely. Porcelain services were to be made for the Tuileries, Versailles, the Trianon, Compiègne, Fontainebleau, Rambouillet and La Malmaison, not to mention the palaces at Milan and Rome. In addition Sèvres had to provide for the requirements of the court, and for Napoleon's relatives in Westphalia, Italy and Spain; while it was necessary to manifest the imperial pomp by presents of unheard-of richness.

As early as 1802 Napoleon had not hesitated to present 
Lord Malmesbury, after the Treaty of Amiens, with a tableservice, of tortoiseshell-ground, worth 17,640 francs. In 1807, in the night between a Sunday and a Monday, there came a sudden order to Sèvres to pack up the "Olympic" service of the Emperor, which will be described later on, and despatch it at once to Russia; while some weeks afterwards a further present was made to the Czar of the "Egyptian" service, valued at 44,000 francs, without mentioning some magnificent vases, painted by Drölling, which accompanied it. Prince William of Prussia, the King of Würtemberg, received in 1809 a magnificent present of Sèvres porcelain, but Napoleon's munificence was especially shown in the presents which he made on the occasion of weddings and christenings. On the marriage of the Princess Stéphanie to the Grand Duke of Baden in 1806, splendid presents of porcelain were sent both to the married couple, the principal witnesses, the officiating bishops, the court chamberlains, and the master of the ceremonies. When Jérôme Bonaparte married Catherine of Würtemberg another distribution of Sèvres porcelain took place; but naturally the greatest luxury was shown at the baptism of the King of Rome. The Duke of Würtemberg (the godfather) received 42,700 francs' worth of porcelain pieces, Madame (the godmother) 36,700 francs' worth, Queen Hortense (another godmother) 15,400 francs' worth; the Cardinal Fesch 25,000 francs' worth; while the chamberlains and other officials had magnificent presents of lesser value. Finally a large porcelain baptismal font with "The Trinity and the Four Evangelists," painted by Rousset, was sent to the Pope, and this piece is still preserved in the museum of the Vatican.

It need hardly be said that all these productions were in the most grandiose style. The shapes of all the tableware had been very much modified from the old Sèvres models of Duplessis, and the pure French style of the eighteenth century was replaced by a bastard style founded on Etruscan and Egyptian art. The "Egyptian" service, which had been made for use in the Tuileries, on great occasions, ${ }^{*}$ had a blue ground decorated

* This was the service presented to the Czar in 1807. 


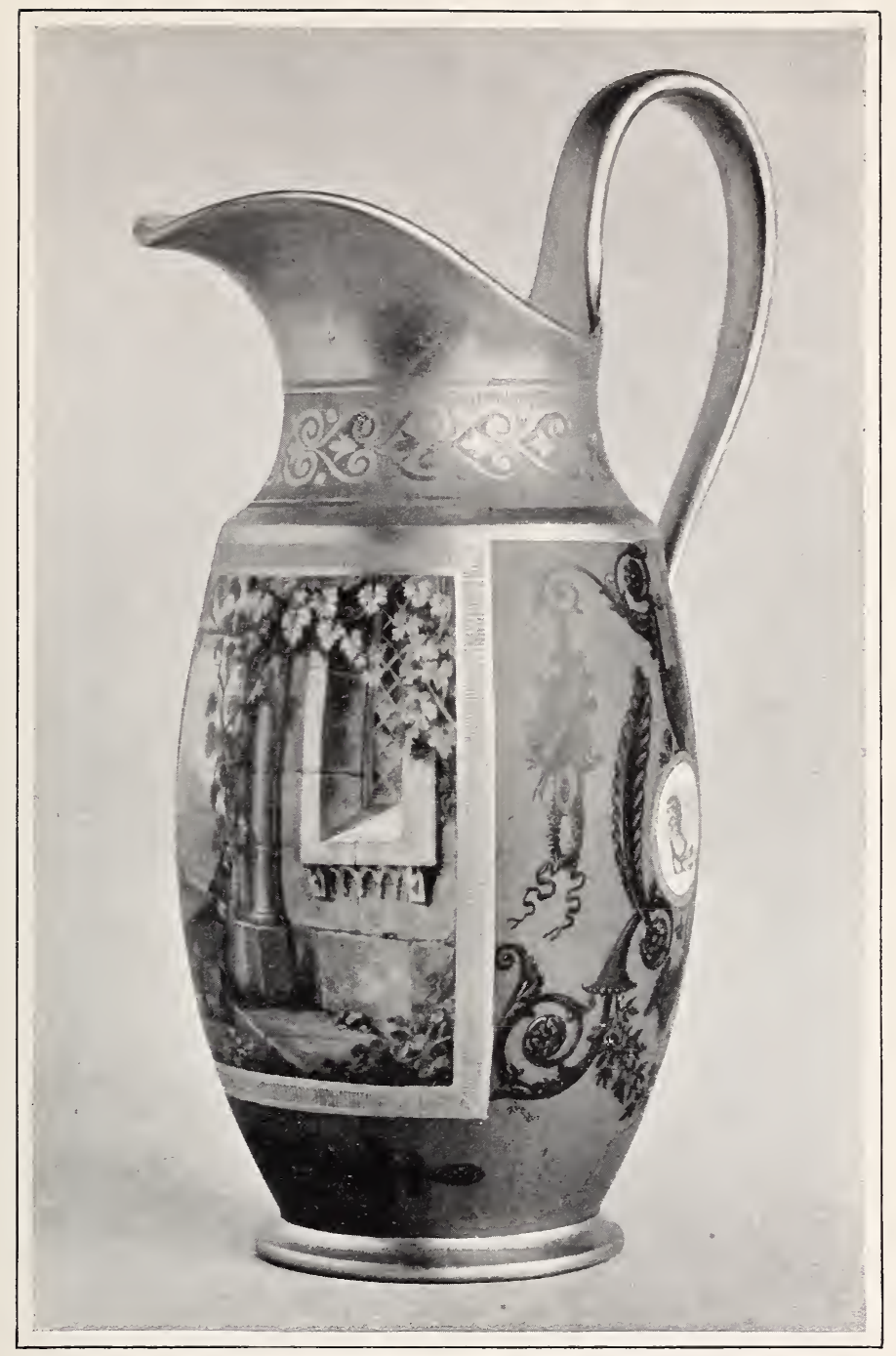

sìvres (Pâte dure).

Fig. 58.-MILK JUG: BROWN GROUND (Fond Écaille) DECORATED WITH PAINTED CAMEOS AND GILDING, AS WELL AS WITH A FRAMED GROUP OF "FOX AND GRAPES."

H. $7 \frac{3}{3}$ in. Dia. $3 \frac{1}{4}$ in.

Victoria and Albert Museum. 

with hieroglyphics in gold, and with paintings in grisaille of Egyptian views by Sweebach, after Denon. This suite comprised a centre piece in the shape of the temple of Philæ, while the side pieces were two other temples; and there were also figures of Memnon, and sphinxes for the ends of the table.

The Emperor's "Olympic" service had a centre piece in "biscuit," the figures of which were taken from the "Musée Napoléon." These figures escorted a "Chariot of Victory," while all the table pieces of the service had a chrome-green ground richly bordered with gold, and the centres of the plates and dishes contained paintings commemorating Napoleon's campaigns.

Among the vases of this period we may mention the "Cordelier Vase" representing the triumphs of Æinilius Paulus and Alexander; the vases of the "Four Seasons" decorated with flowers, which are preserved in the museum of the Trianon; the vase in the Etruscan style, commemorating the battle of Austerlitz, which we have already mentioned; and a series of vases with paintings of Napoleonic subjects, such as "The review of the armies of the Emperor under the walls of Vienna," "Napoleon entering Berlin," "The Emperor saluting the enemy's wounded after Jena," and "The triumphal march of the Emperor."

The most wonderful of all these vases was a vase of the form known as the "Medicis," with a blue ground, bearing a representation in bas-relief of the marriage of Napoleon and MarieLouise in 1810, designed by Isabey. In the middle portion of the vase the Emperor gives his hand to Marie-Louise; the principal figures are in court dress, and are preceded by the great dignitaries of the Empire, and followed by chamberlains holding the trains of the princesses of the Imperial Family. Then come the generals, the diplomatic corps, and members of the Academy; while high officers, offering their arms to ladies, close the procession. Below this central group a great crowd, especially of wornen, is represented, who stretch their arms and acclaim the sovereigns. The first and most important of these groups contained one hundred and fifteen figures, while the second contained representations of from two to three thousand 
figures. This vase cost 30,000 francs to produce, and was not completed until 1813.

Another feature of the works under the First Empire was the production of monumental porcelain columns to commemorate Napoleon's victories. One of these was more than ten metres in height, while another, made in 1808 , to commemorate the campaign of Austerlitz, was more than five metres high, and this is still preserved in the museum at Versailles.

The imperial court seems to have been especially fond of porcelain tables and furniture, of which we may mention the table of the imperial family, as well as the table of the imperial palaces, and the famous table of Napoleon's marshals, but we shall refer to this production of furniture at Sèvres a little later on.

In 1815, when Paris was invested by the allied armies, Sèvres was occupied by the Prussians, but the manufactory was protected, and the Prussian officers secured it from damage. However, on July 3rd, they took 10,000 francs from its cash box as a contribution to the military chest of the 4th Prussian corps, and General Blïcher commanded an inventory to be made of all the porcelain pieces in order that some might be sold in Paris at reduced prices for the benefit of the Prussian army, while the Sèvres porcelain pieces made in commemoration of the history of Napoleon were to be packed up and sent to Berlin. It appears as though this were done to secure a money indemnity, for when Brongniart protested, Bliicher offered to compromise for the 10,000 francs taken from the treasury by force, the porcelain pieces already sent to Berlin, and a further sum of 60,000 francs. Louis XVIII. also protested that the Allies were plundering an establishment which belonged to his family and not to France, but in spite of all efforts at compromise the works was finally plundered and the warehouses and showrooms emptied. Fortunately the annual subsidy from the State which varied from 200,000 to 215,000 francs, was not interrupted, but as the treasury had no money at the moment they raised a fund for immediate purposes by selling off all the remaining stock of the old soft-paste porcelain pieces, both in white as well as in 


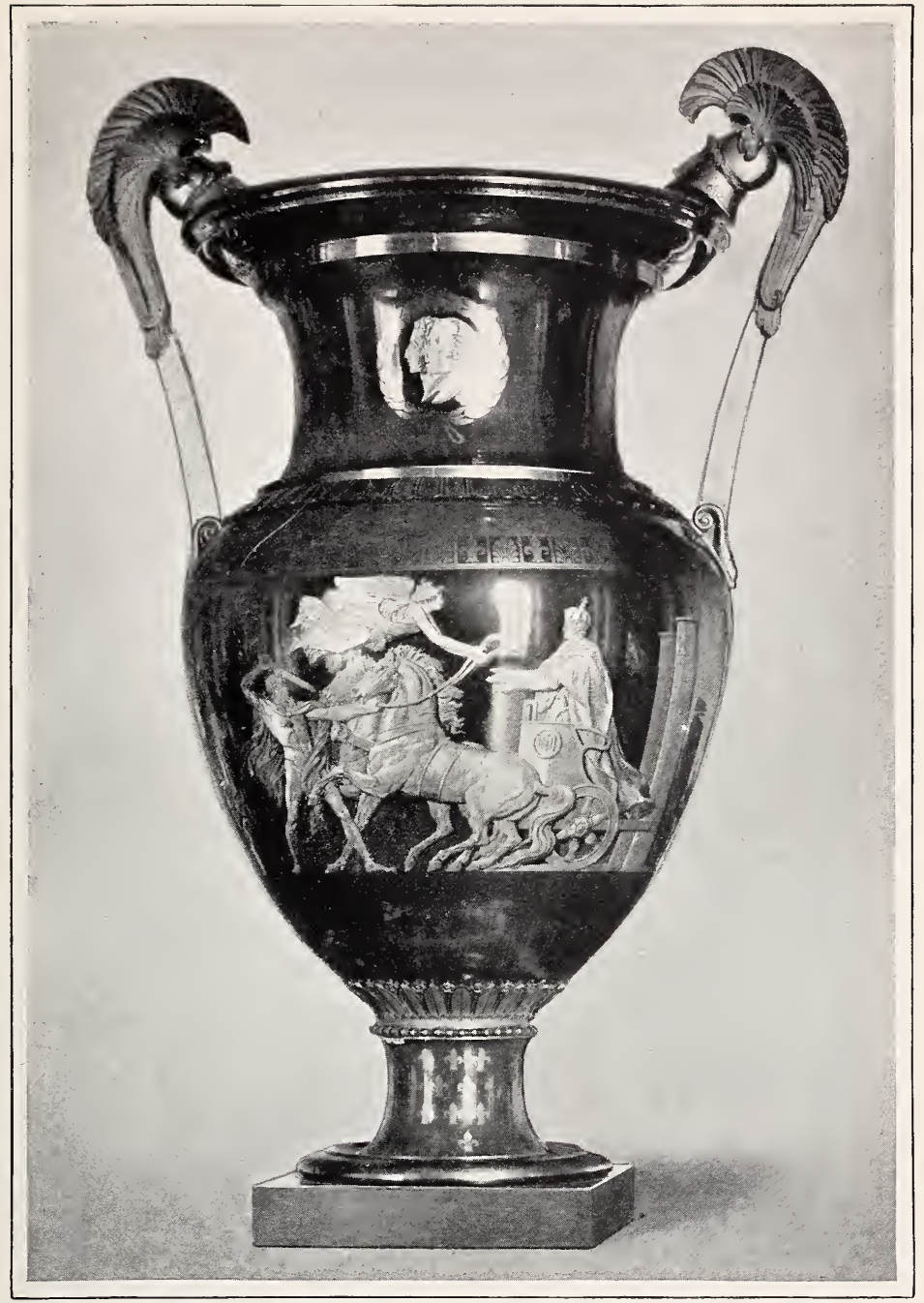

Sìvres (Pâte dure).

Fig. 59.-vase commemorative of the spanish EXPEDITION OF 1823 . CHROME-GREEN GROUND WITH SILVER AND PLATINUM. MEDALLIONS OF LOUIS XVIII. AND CHARLES $\mathrm{X}$. LOUIS XVIII. IN CHARIOT. PERIOD 1824-25.

H. $4 \mathrm{ft}$.

"Grand Trianon," Versailles. 

colours, which had been hidden in the cellars of the manufactory.* The subsequent revolutions from 1815 to 1848 had little or no influence on the finances of Sèvres, which continued to receive a regular annual subsidy of from 300,000 , to 350,000 francs during that period.

The scientific and artistic influences which had been at work at Sèvres continued under Louis XVIII., Charles X., and LouisPhilippe. Large monumental vases were produced such as those illustrated in Figs. 59 and 60, which are absolutely typical of the taste of the period. The forms of the vases are directly inspired by the "antique," and the hardness of their outlines is accentuated by the dryness of the hard porcelain of which they are composed. As we have already remarked the material itself is seldom visible, being covered with colour, with painting, or with gilding, while to reinforce the effect of the gold, decorations in silver and platinum were also used. There is nothing in such pieces to recall the charming gracefulness of the soft-paste porcelain made at Sèvres in the eighteenth century. They are able, learned, and technically skilful, but entirely lacking in artistic feeling or taste.

The fashion of making or decorating pieces of furniture with porcelain which we have already mentioned in connection with the First Empire, continued during the succeeding reigns, and we find the architect Percier designing mantelpieces in 1822, and a bookcase for the King's prayer-books in 1824, the panels of which represent the most famous personages in the history of Christianity. In 1826 we have a writing-desk made in porcelain and decorated with skilful paintings by Jacobber; in 1828 a writing-desk decorated with figures emblematical of literature, arts and sciences; in 1830 a bookcase commemorating the history of Versailles, while the same year saw the production of a colossal inkstand ornamented with portraits of princes of the Bourbon family, a signal example of the elaborate and inartistic style of the period. A

* Much of this soft-paste porcelain found its way to England and was decorated in the Sèvres style by English painters. See Burton's "History of English Porcelain," Cassell \& Co. Ltd., London, 1902, p. 167.--ED. 
small snuff-box was made for the King in 1832, and this was decorated with twenty-five miniatures prettily painted by Madame Jacquotot.

The most important and characteristic productions of the period were, however, the large porcelain plaques, or slabs painted with copies of famous pictures. It is only by carefully studying the examples preserved at Sèvres that one can form an idea of the perfection with which these works were executed by such artists as Madame Jacquotot, M. Constantin and Madame Ducluzeau. The transparency of the flesh colours, the richness and quality of the dresses of silk and velvet, the delicacy of the lace, and the brilliant sparkle of the jewels have alike been rendered with wonderful fidelity. Neither must we forget that the skill of the artists was supported by at least an equal degree of manufacturing skill which could produce such large and wonderfully even plaques of porcelain, and glaze and fire them successfully, with all their tender and subtle gradations of colour.

During the whole of the period under review there seems to have been no great production of sculptured "biscuit" pieces. It must suffice to mention the busts of Napoleon I., of Louis XVIII., and of Charles X. Busts and profile medallions of Louis-Philippe, and of the members of his family, were also executed, while some decorative figure groups were modelled by Klagmann, but it cannot be said that they were very satisfactory.

As was natural under so many changes of government the marks used at Sèvres varied considerably during the first half of the nineteenth century. In 1801 the mark was "T. 9.," in 1802 " $\mathrm{X}$ " (the year 10), in 1803 "II" (the year 11) accompanied by the word "Sèvres"; in 1804 a horizontal stroke crossed by two oblique ones with the inscription " $\mathrm{Man}^{\mathrm{re}} \mathrm{Na}^{\mathrm{le}}$ Sèvres"; in 1805 "Mre Imple Sèrres," with an angle bisected; in 1806 the same lettering, with two horizontal lines, each having a large dot in the centre (see Section on "Marks"). In 1807 a date mark was again added to the inscription, being " 7 " for 1807 , " 8 " for 1808 , and " 9 " for 1809 ; while in 1810 , besides the same inscrip- 


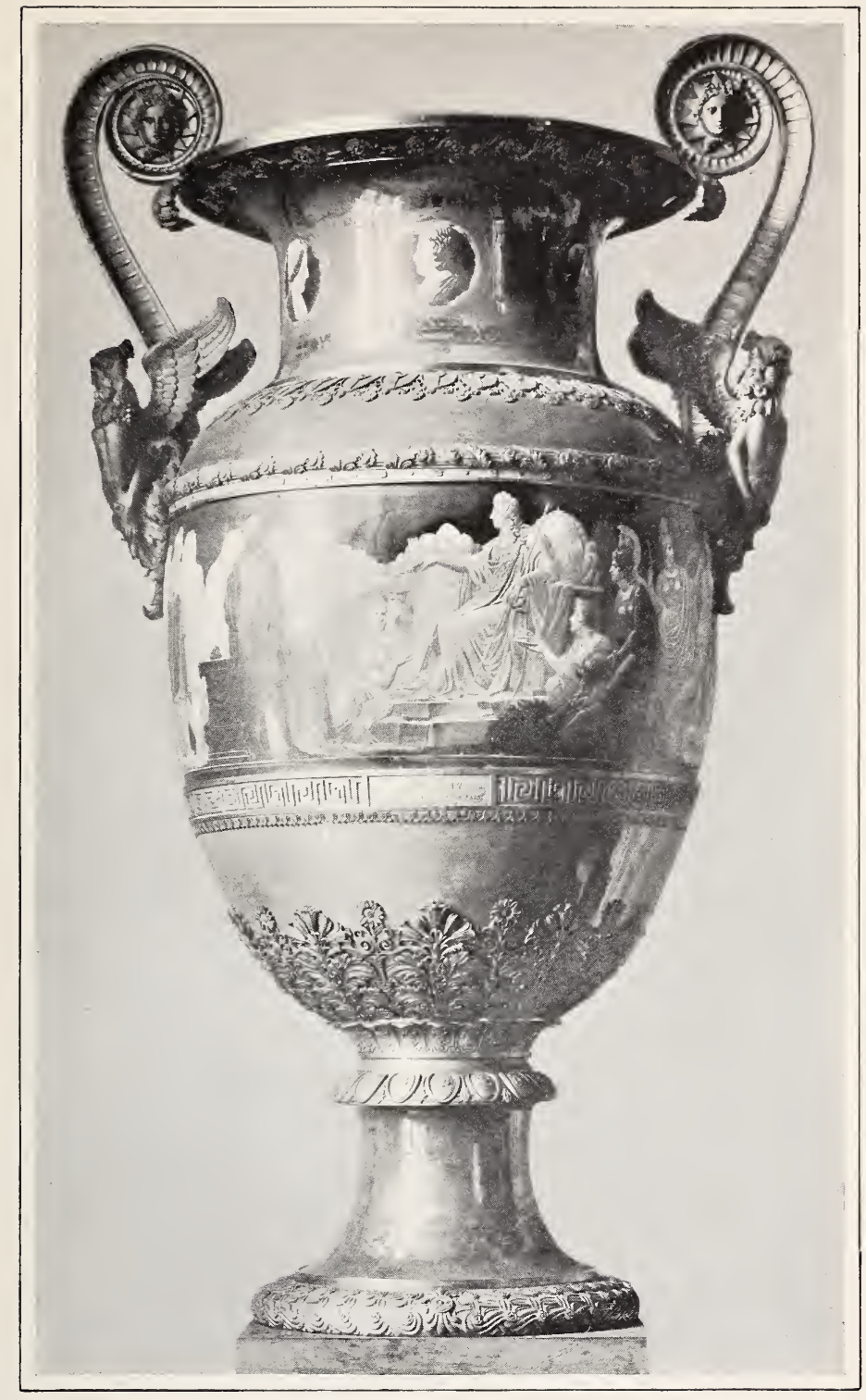

S̀ेvrES (Pâte dure).

Fig. 60.-VAse with paintings Representing "The TRIUMPH OF LOUIS XIV." METAL MOUNTS AND HANDLES. PERIOD 1840.

H 5 ft. 8 in.

"Grand Trianon," Versailles. 

tion and the date mark, the "Imperial Eagle" was added and was continued to 1814. After 1810 we find the "Imperial Eagle," with the addition of "O. Z." (onze) for 1811 ; "D. Z." (douze) for 1812; "T. Z." (treize) for 1813; and "(Q. Z." (quatorze) for 1814; while in 1815 the "Imperial Eagle" was again used, with the addition of the letters "Q. N." (quinze). In 1814, during the exile to Elba, the two crossed "I's." with a fleur-de-lys reappear, and above the monogram the word "Sèvres," and the letters "Q. Z."

From 1815 we find the two crossed "L's." again, with the fleur-de-lys and the date marks "S. Z." (seize), "D. S." (dix-sept) and so on.

Under Charles X. the mark from 1824 to 1827 was two interlaced "C's." with an " $\mathrm{X}$ " in the middle and a fleur-de-lys below, while from 1827 to 1830 we find two interlaced "C's." enclosing a fleur-de-lys, and in addition to both these monograms the word "Sèvres," and a date mark consisting of the two last figures of the year are also given. In 1830 we find " $\mathrm{C}^{\mathrm{x}}$," surmounted by a crown, and for the decorated pieces from 1829 the two "C's." with an "X" between them surmounted by the royal crown, and with the words "Décoré à Sèrres." In 1830 we also find a mark of a fleur-de-lys, with the word Sèvres and the two last figures of the year.

From 1830 to 1834 a circular stamp contains the word "Sèvres," with a six-rayed star and the date mark for the year above it. From 1834 to 1848 we find the initials "L. P." (LouisPhilippe), surmounted by the royal crown and accompanied by the date mark.

All these marks are in blue, red, or green over the glaze. It should be remarked that after 1831 certain services and pieces intended for use in the royal châteaux were marked in addition "C. H. Dreux," "C. H. Tuileries," \&c., in blue, over the glaze. 


\section{CHAPTER XVII.}

A SKETCH OF THE MODERN DEVELOPMENTS OF FRENCH PORCELAIN.

Although it is a little too early to write the history of the developments of French porcelain in the last half of the nineteenth century it is desirable that we should give a brief sketch of the progress that has been made both at Sèvres and elsewhere.

To deal first with Sèvres. On the death of Brongniart his associate, Ebelmen, continued his traditions for a time, and as the Revolution of 1848 had no effect on the works at Sèvres they were able to exhibit in the London Exhibition of 1851 exceedingly thin cast pieces of hard-paste porcelain in imitation of the Chinese "egg-shell" and "pierced" porcelains.

Ebelmen, however, died prematurely in 1851, and was succeeded by Victor Regnault, the famous physicist, who, having no artistic taste, went still further in developing the technical side of the Sèvres manufacture at the expense of its artistic qualities. It is to his inventive skill that the methods of casting large porcelain pieces by the use of compressed air, or of a vacuum, to keep them in shape during drying, were due.

In the museum of the Petit Trianon there are now displayed a number of pieces made at this time from a mass of the old soft-paste material that had been found stored in the cellars of the manufactory, but it cannot be said that from the point of view of perfect production these pieces were a success. 
In 1855 Queen Victoria paid a visit to Sèvres and was presented with a plaque of hard-paste porcelain painted with a copy of Ruysdael's picture, "The Burst of Sunshine," while in 1856 the Prince Consort was presented with a vase in "biscuit," with a red ground, on which Brunel-Rocques had painted an allegorical picture of the countries of the world bringing their productions to the Universal Exhibition.

The most important artistic development during this period was the gradual perfection of the famous process of pate-surpate. This process, in which porcelain clays of various colours could be used in conjunction, or, as it was finally developed, in which cameo-like effects were produced by painting and modelling with semi-fluid white slip on a coloured ground, appears to have been first developed by Robert, the head of the painting department, at the instigation of $\mathbf{M}$. Riocreux, the learned keeper of the Sèvres museum. In 1862 a number of small cups were exhibited at the Universal Exhibition in London, decorated by Gély with subjects from La Fontaine's fables, bordered with ornamental devices and flowers executed in this way. In spite of some technical defects these pieces, which are now preserved in the museum at Sèvres, form an interesting contribution to the history of the development of ceramic art. This famous process was further developed by M. Solon-Miles, who by his exquisite skill and profound knowledge brought to perfection this method of painting in bas-relief.* We may also mention the work of $\mathrm{M}$. Gobert, whose executive skill was of the highest order, and whose talents as a figure-painter made their influence felt on the whole production of Sèvres during this period. Mme. Escalier also designed some beautiful compositions of flowers and birds which were either executed by herself, or by skilled workers such as Célos.

It should also be mentioned that during this period the palette of on-glaze colours was considerably extended by the

* An account of this process of pâte-sur-pâte decoration will be found in Burton's "History of English Porcelain" in connection with Mr. Solon's famous productions for the English house of Minton.--Ev. 
addition of what are known as hard-kiln colours (couleurs de demi-grand feu) of the utmost brilliance, and some excellent painting was executed in this manner on the hard-paste porcelain by Mme. Apoil.

The exhibition of 1867 at Paris found the works at Sèvres showing an enormous collection of pieces, remarkable rather for their technical skill than for their taste. All the styles were represented, whether Etruscan, Chinese, Japanese, Arabic, or Louis XVI., not to mention European styles of decoration on Chinese forms, and other bizarre conceits.

Toward the end of Brongniart's directorship the buildings at Sèvres had been found too cramped for all the processes that were conducted there, and as the result of an enquiry in 1853, it was decided to build a new manufactory. Laudin, brother-inlaw of the director Regnault, was entrusted with the plans of the new works, which was to be built on the banks of the Seine, just within the park of St. Cloud. The building was commenced in 1861 and was well advanced at the outbreak of the Franco-German war in 1870.*

After the disaster of Sedan it was immediately decided to transport all the products of the factory, the specimens in the museum, and the books of the library to Paris, and they were accordingly removed to the cellars of the Louvre and other public buildings in Paris. The removal lasted from. September 6 th to September 18th, and was only just completed in time, for on September 19th the bridge of Sèvres was blown up and the manufactory was in the hands of the Germans. Regnault, the director; Salvétat, the chemist; Riocreux, the keeper of the museum; and Robert, the chief painter, remained at Sèvres, but all work ceased. No plundering was done as in 1815, although in spite of an order issued by the staff of the Crown Prince of Prussia, some marauders broke into Regnault's laboratory and pillaged it. Some of the models of the eighteenth century productions had already been installed in the buildings of the

* It may be mentioned that the old manufactory was transformed into a normal school for young girls, and is still used for that purpose. Visitors will find the buildings in the little town of Sèvres itself. 


\section{PLATE XXIIT.}

\section{SËVRES}

(PÂTE TENDRE, ABOUT 1768).

\section{Vase}

With Royal Arms and Turquoise Ground; mounted on a High Porcelain Pedestal Framed in Gilt-bronze. Group of Rustic Figures Painted by Genest; the Flower-painting UNSIGNED.

Wallace Collection, No. 15, Case in passage between Galleries $X X$. and XXI. 



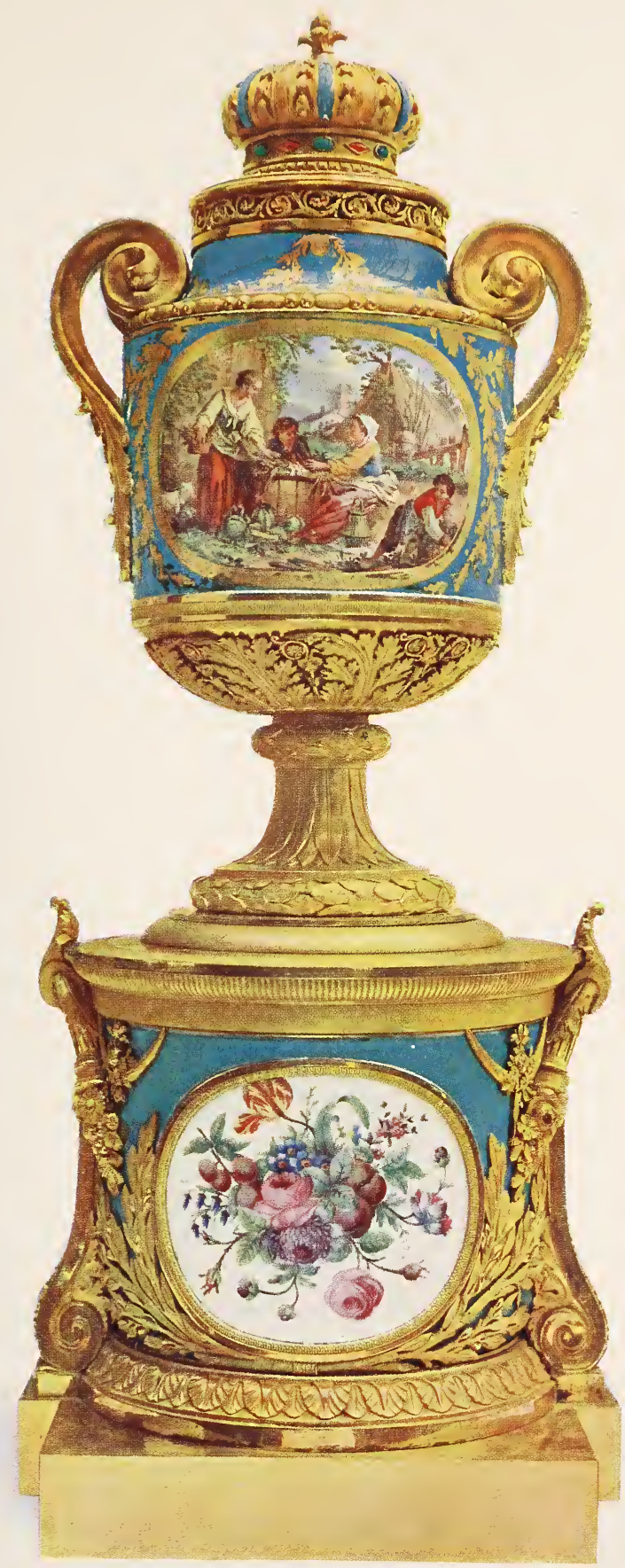



new manufactory and many of these were unfortunately stolen or broken.*

After the war, Regnault, whose son had been killed, was unable to continue at his post, and Robert became the head of Sèvres until 1879.

The new manufactory was inaugurated by Marshal MacMahon in 1876. During this period, however, the strongest complaints were levelled at the Sèvres manufactory by art critics and connoisseurs, as well as by the general public, because in spite of the technical skill of its productions it was accused of following rather than leading the general taste of the day. Finally, in 1876, a commission of artists, potters, and critics was appointed, in the hope of improving this state of affairs, and it was decided that Sèvres, besides existing as a works where costly and laborious researches beyond the reach of ordinary manufacturers could be undertaken, should also become a school of industrial art, and a nursery for training artists and craftsmen capable of directing either the scientific or the artistic departments of the other French porcelain works. For this purpose the annual state subsidy, which up to 1870 had been maintained at from 320,000 to 350,000 francs has been successively raised to about 625,000 francs, at which it now stands. The productions of Sèvres are no longer needed for the decoration of royal palaces, but are used for the embellishment of museums, libraries, theatres, prefectures, \&c., while the system of diplomatic presents has been continued and extended, and the chief ambassadors and ministers, like the head of the State, have been presented with the most sumptuous table-services.

This programme was largely realised in the period from 1879 to 1887 , under the directorship of M. Ch. Lauth, the eminent ceramic chemist, who surrounded himself by artists like CarrierBelleuse, Rodin, Desbois, Dalou, Chéret, and others.

In the hands of M. Lauth the experiments of Régnier, Ebelmen, and Salvétat for the production of a new porcelain

* Recently M Brinckmann, the director of the Hamburg Museum, has offered to the museum at Sèvres a precious collection of bas-reliefs in wax, of the end of the eighteenth century, which had been stolen from Sèvres in 1870, and which he had secured from the sale of an officer's effects. 
body reached completion, and the new porcelain of Sèvres, which can be decorated with all the colours and enamels used by the Chinese, is now a staple production of the works.

In the period between 1879 and 1889 they also produced magnificent specimens in imitation of the old Chinese Céladon, Sang-de-boeuf and Flambé pieces.* In fact great attention was paid to the study and imitation of old Chinese methods, and one of the triumphs of Sèvres during recent years was the reproduction of a Chinese plate in the Sèvres museum known as "the plate with the seven borders" which was so successfully carried out that it is difficult to distinguish the original from the reproduction. $\dagger$

. In 1887 M. Lauth was succeeded as director of Sèvres by the famous potter Deck, whose principal efforts were directed to the production of grès (stonewares) and a soft-paste porcelain having a glassy basis. Deck, however, died in 1890 and was succeeded by M. Baumgart, an official from the department of the Beaux-Arts, who still holds that position.

The magnificent display of porcelain pieces made by Sèvres at the Universal Exhibition of Paris in 1900 gave one a fine idea of the present condition of the establishment. The collection comprised pieces of soft-paste porcelain, pieces of hard-paste porcelain, and of the new Sèvres porcelain which we have just mentioned. The hard-paste porcelain pieces were either white or decorated with coloured clays, or with under-glaze colours. It might be urged against the majority of these pieces that they seemed to have been too much inspired by the styles introduced and deve'oped at Copenhagen.

In the new porcelain body magnificent groups of "biscuit" pieces were exhibited, among which we must especially mention the superb table garnitures of M. Frémiet, M. Léonard and M. Gardet, while the figures designed by such artists as A. Boucher, Chéret, Barrias, Paul Dubois, Suchetet, Felix Charpentier, Desbois, etc., were also of great merit.

* It shonld be remarked that this success was largely due to the special furnaces devised and constructed by MI. Auscher during this period.-ED.

+ A similar Chinese plate is in the British Museum Collection. 
The glazed pieces were decorated with crystalline glazes, with coloured pastes under the glaze, and with every variety of under-glaze and on-glaze colours.

The new soft paste of Sèvres, made in the period from 1887 to 1900 , does not, however, equal in its quality the old solt paste of the eighteenth century, the pieces being too glassy, and the appearance altogether too glittering.

It may also be mentioned that a considerable collection of stoneware pieces (grèscérames) was exhibited, but any description of these would be beyond the scope of this volume.

The marks on the Sèvres porcelains from 1848 to 1900 necessarily changed considerably, and a complete series of these will be found in the Section on "Marks." We must, however, point out here that from 1848 to 1851 the mark consisted of the letters " R. F." in a circle, and beneath the letter " $S$. ." and the two last figures of the year. It must also be mentioned that in 1848 it was decided to mark every piece in chromium-green before it was glazed, and this chromium-green mark was most characteristic, as it was impossible to imitate it over the glaze.

From 1852 to 1854 the mark consisted of an eagle framed by the letter "S." on the left-hand side and by the two last figures of the year on the right-hand side. From 1854 to 1870 the mark was an "N." with the imperial crown, with the inscription "Doré ì Sèves" and the two figures for the year; while the pieces of soft paste produced during the period bear the letter $\mathrm{T}$ under the N. From 1871 to 1874 the mark was a circle enclosing the two letters "R. F." over the letter "S." and the date mark, while from 1874 to 1892 the letters "R. F." were interlaced and surmounted by the words "Doré ¿̀ Sèvres" or "Décoré à Sèvres." These marks are in onglaze red. From 1888 the mark is that of a thrower at his wheel, surrounded by the inscription "Sèvres" and the two figures indicating the year (see Section on "Marks.")

Between 1810 and 1848 the gilded and decorated pieces bore only a mark on the glaze, but a careful examination of the body of the pieces reveals marks, engraved in the paste, of the initials of the thrower or of the maker, and the date mark. 
When a piece of that period was sold as imperfect it bore no mark, but after 1848 all the rejected pieces had a wheel-cut made through the "chromium" mark under the glaze, while the marks "Doré à Sèvres" or "Décoré à Sèvres" occur only on choice pieces.

In addition to this it must be said that the "biscuit" pieces bore the impressed stamp "Sèvres" in an oval until 1893, while the initials of the figure maker and the year were also impressed in the paste. Since 1893 the mark of the thrower at his wheel, already referred to, has been impressed in the "biscuit" pieces.

A fow words must also be given to the progress made in the development of French porcelain by the independent factories, particularly those of Limoges.

When once the restrictions imposed by the old royal edicts had been removed, at the time of the Revolution, the existence of the kaolin beds near Limoges naturally led to a further development of the hard-paste porcelain industry in that district. We have already traced the growth of the hardpaste porcelain industry in Paris, and the firms of Guerhard and Dihl (see p. 138) as well as that of Nast (see p. 138) continued their traditions of good manufacture under the first Empire. The productions of Caen at the same period have also been referred to (see p. 124),

It was, however, at limoges itself that the industry soon attained a condition of importance. The hard-paste porcelain factory at Limoges, which we have already mentioned as forming a branch of Sèvres (see p. 125), was continued by M. Alluaud and is still a thriving and prosperous concern, producing to-day, under the style of Pouyat and Alluaud, excellent table-services, toilet-sets, and tea- and coffee-services of perfect white paste and excellent glaze, capable of receiving an extensive palette of on-glaze colours.

It would be impossible to mention all the factories that have been developed in the vicinity of this town, but no mention of it would be sufficient that did not contain the name of M. Charles Haviland, a naturalised Frenchman, who came from America in 1840, and founded a works to produce porcelain for the 
American market; an enterprise which really laid the foundation of the commercial success of Limoges. Under his energetic enterprise the hard-paste porcelain industry has been developed by the best mechanical appliances, the introduction of new ovens and new methods of firing, and the perfection of the method of porcelain-decoration by chromo-lithography. It must not be supposed, however, that M. Haviland's skill has been entirely directed to the mechanical improvement of the processes of hard-paste porcelain. All the older methods of under-glaze and on-glaze painting have been skilfully practised in his extensive works under such artists as Bracquemond, Dammousse, Boilvin, Delaplanche, Ringel and many others.

The rival firm of Théodore Haviland, founded by his brother, has recently perfected methods of gas-firing, and of firing decorated pieces in a continuous kiln, which must be of great advantage from the point of view of commercial production.

At the present time the porcelain of Limoges finds its way into the markets of the whole world on account of its excellent quality, the skill of its decoration, and especially the cheapness of its production.

Excellent "biscuit" pieces and groups have been produced by the house of Raymond Laporte, while the whole of the hardpaste porcelain industry is indebted to two chemists, M. Halot and M. Peyrusson, who after years of sedulous research have successfully developed the palettes of colour, both under-glaze and on-glaze, employed by the Limoges potters.

Rival establishments have been established at Vierzon and at Mehun-sur-Yèvre, by the firms of Hache \& Co. and Pillivuyt $\&$ Co. respectively, who, however, follow the styles of Limoges.

The hard-paste porcelain industry still survives in Paris, where there are small factories producing special articles such as porcelain flowers, dolls' heads, "biscuit" vases and groups for church decoration; and a number of decorators' workshops where white pieces from Limoges or Vierzon are decorated.

It should be added that there is a growing industry in the manufacture of porcelain buttons at Gien, in the centre of 
France, while mention should be made of the production of the porcelain vessels used by chemists and physicists, especially for work at high temperatures, which is made a speciality at Bayeux.

We have already mentioned in a previous chapter that the soft-paste porcelain works of Tournay and Saint-Amand were continued through the greater part of the nineteenth century, but we must direct especial attention to the soft-paste porcelain of M. Naudot, of Paris, who has successfully reproduced a softpaste porcelain comparable with that of the old soft-paste pieces of Sèvres. His most original work is, however, in the direction of "pierced" porcelain in imitation of the perforated patterns known as "grain of rice" patterns of the Chinese, though M. Naudot fills the perforations of his pieces with brilliantly coloured glazes which produce a jewelled effect when seen against the white porcelain body.*

In conclusion we must add that the rouge-flambé glazes of the Chinese have also been successfully reproduced by M. Chaplet at Choisy-le-Roi, Théodore Deck, M. Girault-Demay and many others.

* Perforated porcelain pieces of this same style were produced by the Worcester Porcelain Company in England, and were exhibited at the Vienna Exhibition in IS73. -ED. 


\section{PLATE XXIV.}

\section{SËVRES}

(PÂTE TENDRE, ABOUT 1776-1779).

\section{Vase "Cassolette",}

Mounted in Sculptured Bronze-gilt; Turquoise Ground decorated with Rich Gilding and Cameos on Red-brown Panels. Part of Service made for Catherine II. of Russia.

Wallace Collection, No. $\%$, Case in passage between Galleries $X X$. and $X X I$. 



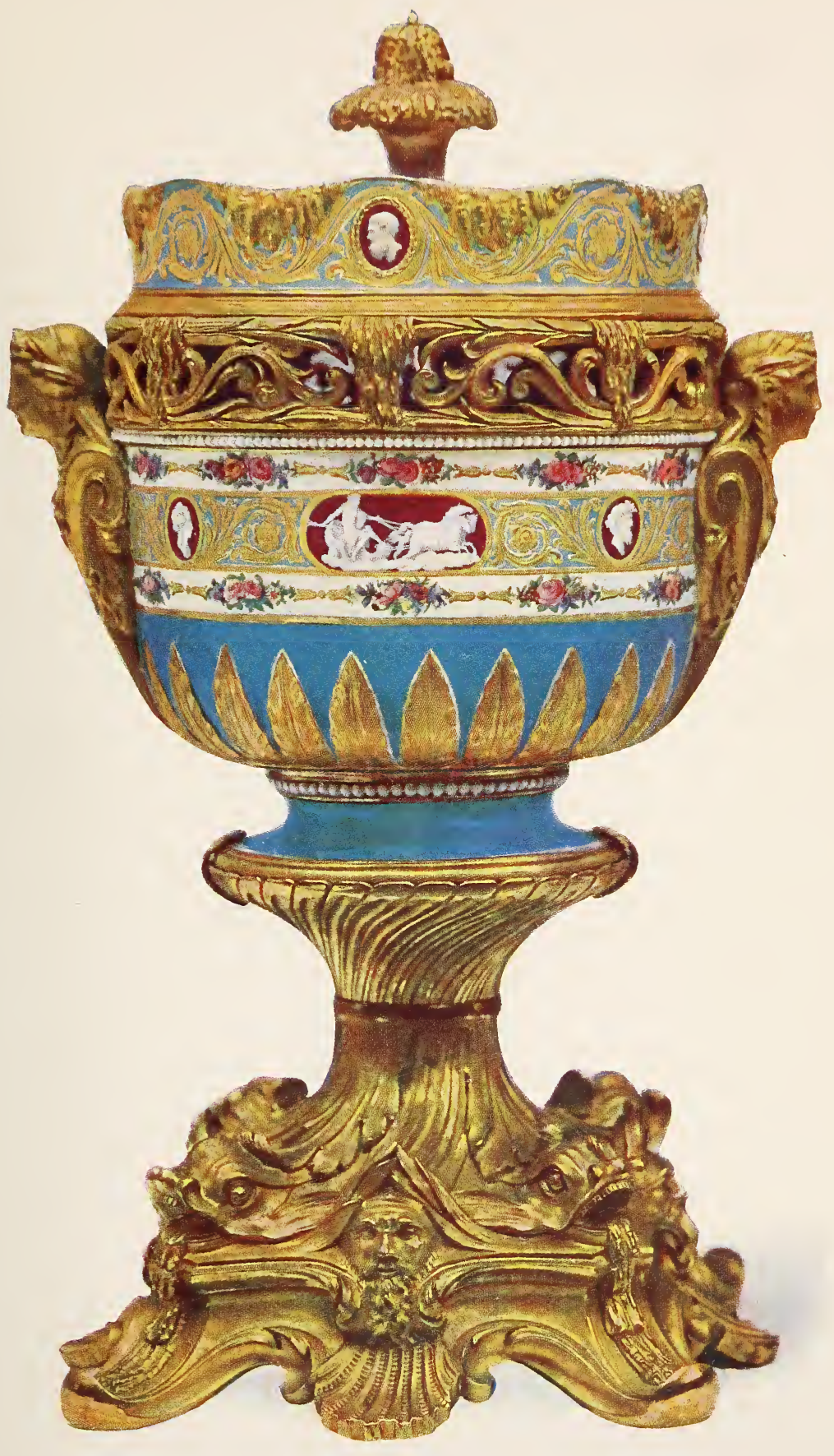





\section{CHAPTER XVIII.}

\section{FRENCH PORCELAIN FORGERIES.}

French porcelain pieces, and especially those of Sèvres, are so highly prized by collectors that they have furnished the most prolific field for modern forgers and tricksters, and although it is impossible to describe all the tricks that have been resorted to in this way, we give some account of them, in the hope that our notes may serve to guide collectors and amateurs in their search for authentic pieces.

To speak first of the old soft-paste porcelains. The best guide is certainly the knowledge that can be obtained by a careful examination of the authentic pieces to be found in museums, which should be studied from the point of view of technique, of design, and of that indescribable sense of touch and style, which the most skilful forger seldom secures.

The early pieces made at Vincennes were often very imperfect in their body and glaze, but from 1755 to 1789 the pieces turned out from Vincennes and Sèvres were wonderfully perfect. To commence with, therefore, one should mistrust all white pieces the glaze of which is not perfectly clear, or is wavy, or uneven from insufficient firing. During the best period of Sèvres all such pieces were refired to avoid these defects. On the greater number of such pieces there is to be found, underneath the foot rims of cups, plates or saucers a small hole drilled in the body, in order that they might be hung up in the mufflekiln during the last firing. We have already pointed out that during the Revolution and the First Empire a large quantity of undecorated soft-paste pieces was cleared out from stock. 
These pieces were sold as they stood, so that many of them were of inferior quality, but they were all decorated either by Parisian or foreign decorators, and falsely marked. In many cases the marking has been done so carelessly that it is quite sufficient to declare the forgery, as for instance when we find the mark of a painter with a date-mark subsequent to his decease, or the mark of a well-known flower painter on a piece decorated with tigure painting. It should be added that the soft-paste porcelain produced at Tincennes during the last few years of that factory and the soft-paste porcelain of Sèvres are alike thin in the body, beautifully white and transparent, and have an extremely glossy and brilliant glaze.

In addition to these false decorations of white Sèvres pieces it is necessary to point out that many genuine, slightly decorated Sèrres pieces have been absolutely remodelled by the forger. Little bouquets of flowers, for instance, and slight gilding would be ground off or remored by a careful application of hydrofluoric acid, and then the pieces would be elaborately decorated with a blue or turquoise ground, so that with rich gilding, they could be sold at a greatly enhanced price. In other instances bouquets were corered with medallions with figures, or paintings of birds might be surrounded by a landscape, but in many cases such frauds reveal theinselves by the fact that in removing the original painting with a grindstone a part of the soft glaze has also been remored, and the colours of the false decoration are often dry and hard-looking when compared with the genuine Sèrres painting on soft paste. It is sometimes possible also to trace through the superposed turquoise or rose-Pompadour grounds a faint silhouette of the original decoration.

We may likewise add that the refiring of gilded pieces always leares traces to the skilled eye, as the gold generally becomes dull and sinks more into the glaze, so that it is necessary to retouch the gilding, a process extremely difficult unless erery mark of the retouching is to remain risible to the initiated.

Pieces of table-services which hare been used, and retain any traces of greasy or oily substances, are apt to "spit" when they 
are refired, producing little black pin-points in the glaze which are unmistakable to an expert.

The porcelain pieces of Mennecy-Villeroy, Bourg-la-Reine, and other factories, decorated in the Sèvres style, in spite of their characteristic colour and their marks incised in the paste, are often to be met with bearing a forged Sèvres mark, but here again the cheat ought only to deceive the unwary.

The porcelain pieces of Tournay and of Saint-Amand are often to be found with the forged mark of the two crossed "L's." of Sèvres, but a comparison with genuine Sèvres pieces will show that these productions are always thicker in the body and less white than the genuine Sèvres pieces.

It should never be forgotten that in the old Sèvres soft-paste time the colour was either painted "impasto" or floated on in the style of water-colour, in a manner entirely distinct from the miniature-like processes of stippled painting with reserved high lights, which was especially used in painting on hard-paste porcelain. The gilding also of the soft-paste porcelain pieces, executed with pure leaf gold ground up in honey so that the metal stands up thickly upon the piece, is absolutely distinctire.

Finally, it must always be remembered that any piece decorated with the characteristic yellowish-green colour of oxide of chromium, or any colour containing a chromium basis, must be later than 1801, when this mineral was first introduced at Sèvres.

It is not too much to say that ninety per cent. of the socalled soft-paste porcelain of Sèvres to be found in collections to-day is not of genuine Sèvres decoration.

As to the hard-paste porcelain pieces it is certain that many of the pieces from the factories of the Comte d'Artois (see p. 130), or of the rue Thiroux (see p. 136) and others which have been originally marked in on-glaze red, have had those marks removed and replaced by the Sèvres mark, without any alteration in their decoration.

The greater number of falsifications of hard-paste Sèvres pieces have, however, arisen from the pieces sent out from the factory between 1815 and 1900 , at periods when white pieces 
were allowed to be sold. Even in pieces where the genuine Sèvres mark has been cut through with the wheel, the cut has often been disguised by a drop of fusible enamel. These white pieces have naturally been decorated with the most elaborate historical paintings representing the history of Louis XIV. or Napoleon, in order to enhance their value, and it is quite common to find such pieces bearing the special marks which would indicate that they had been made for use in some of the royal châteaux. Richly gilded pieces like those used in the royal châteaux of Louis Philippe and Napoleon III. are also often found with the same forged marks.

Certain Parisian factories have long produced, and still continue to produce, large ovoid vases with blue or rose grounds, richly painted and mounted with gilded mounts; as well as tea- and coffee-services, jardinières, and other pieces made in ordinary hard-paste porcelain, decorated in imitation of the soft-paste porcelains of the time of Louis XV. These forgeries are, however, too gross to deceive anyone but the merest tyro.

In conclusion, we may wish that all our readers should possess in their collections none but authentic pieces, but to attain such a desirable end they cannot too closely study the pieces preserved in the public museums, from which the keepers scrupulously clear away, from time to time, all forged pieces, or mark them with distinctive labels. 


\section{A R K S}

$$
\text { OF THE }
$$

FRENCH PORCELAIN. 


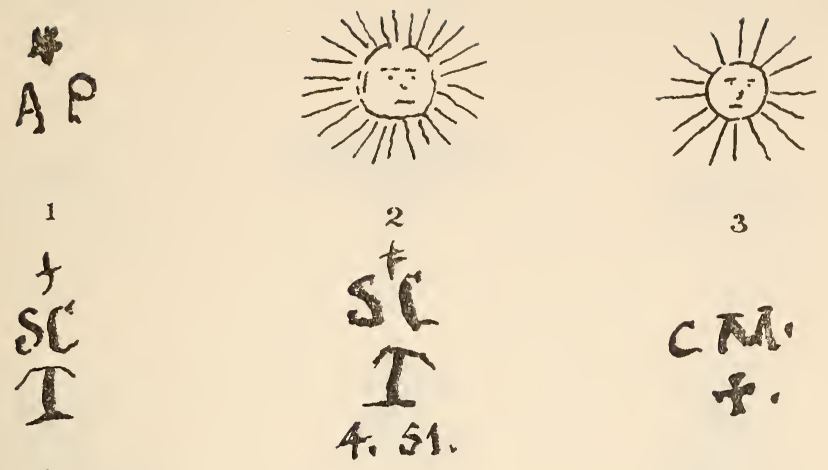

4

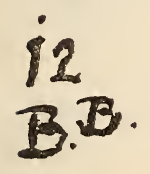

5
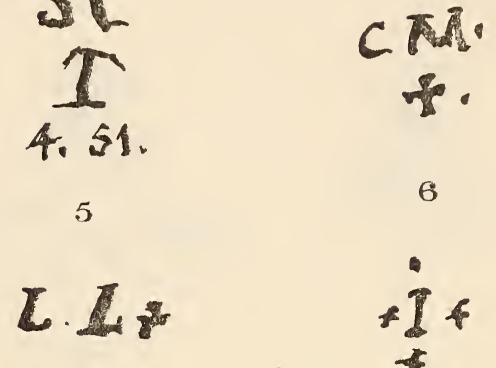

3

6

7

8

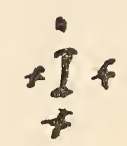

2

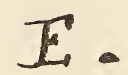

11

12

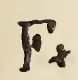

$M+$

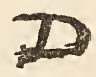

13

14

15

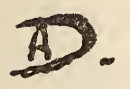

is

$\frac{1}{4}$

16

17

18

1.-Experimental Soft-Porcelatn of Paris (?). Under-glaze Blue. 2-3.-Soft-Paste Porcelain of St. Cloud. Incised in the MoIst PASTE.

4-14.-Soft-Paste Porcelain of St. Cloud. Blue Under-glaze. 


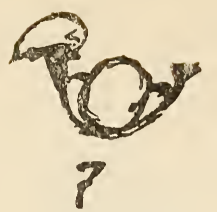

19

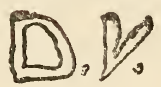

22

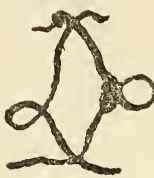

25

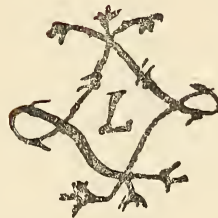

28

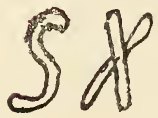

31

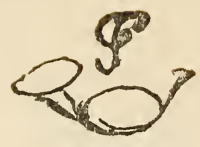

20

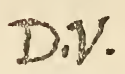

23

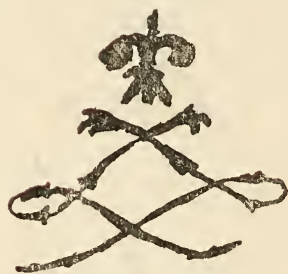

26

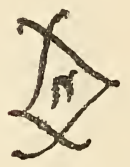

29

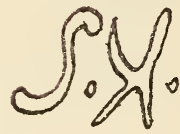

32

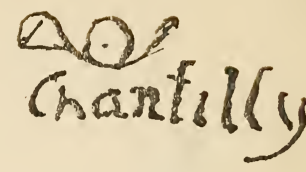

21

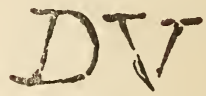

$2 \cdot 1$

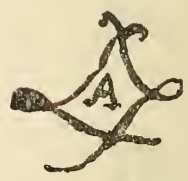

27

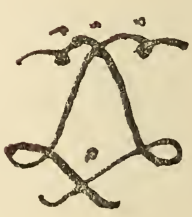

30

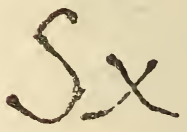

33

19.-Soft-Paste Porcerain of Chantilly. Red On-glaze.

20-21. -

22.-

23.-

2.-

$25-$

$20-$

${ }^{27-}$

${ }^{28-}$

29.-

30.-

$31-33$

\section{BLUE ON-GLAZE.}

, Mennecy. Incised in the Moist Paste. ROSE-COLOUR ON-GLAZE. BLUE ON-GLAZE.

", (about 1753). GOLD ON-GLAZE. (1754). BLUE ON-Glaze. (1753). BLUE ON-GLAZE. SÈvres (1764). Gold ON-GLAZE. (1766). Carmine On-GLazg. "Vincennes (1750). Blue ON-Glaze. , Sceaux. Incisind in the Moist Paste. 
B。艮

34

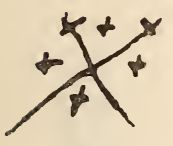

37

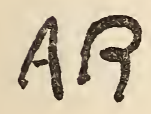

40

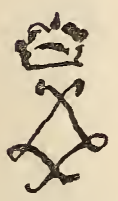

4.3

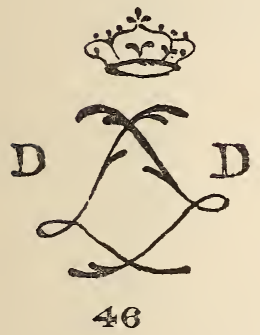

(B) 1 .

35

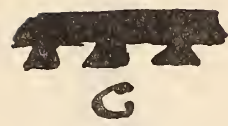

38

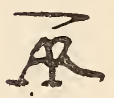

41

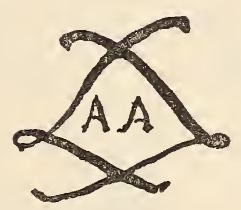

44

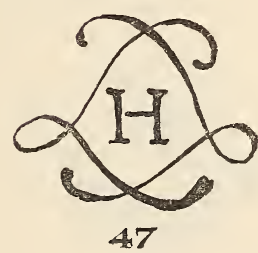

1812

36

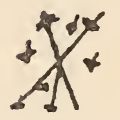

39

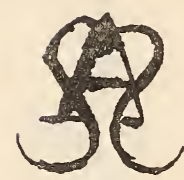

42

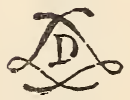

4.5

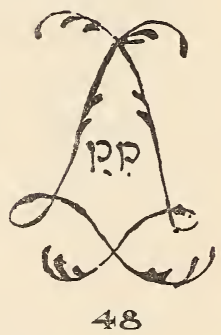

34-36. - Soft-Paste Porcelain of Bourg-La-Reine. Inscribed in the MoIst Paste.

37.-Soft-Paste Porcelain of Tournay. Gold On-glaze.

38.- " " " ORLÉans. BLUE UNder-Glaze.

39.- $\quad " \quad ", \quad " \quad$ TOURNAY. CARMINE ON-GLAZE.

40-41.- " " " $"$ ARras. BluE UNDER-GLAZE.

42.- $" \quad " \quad$ St. Amand. Blue Under-Glaze.

43.-Hard-Paste Porcelain of Sìvres (1775). Grey-Blue On-Glaze.

44.-Soft-Paste ", $, \quad, \quad(1778)$. Blue Under-GLaze.

45.- $\quad " \quad, \quad, \quad, \quad(1756)$.

46.- " " " $" \quad " \quad " \quad$ " $"$ "

$47,-\quad " \quad " \quad, \quad " \quad$ " $", \quad$ (1760). "

48.- " " " " $\quad$ (1791). " 
H

49
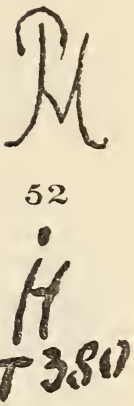

55

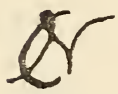

58

TFRRE DE LORRAINE

62

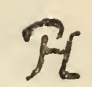

50

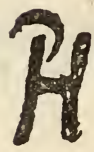

53

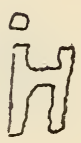

56

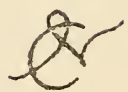

60

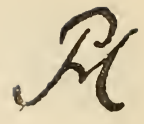

.51

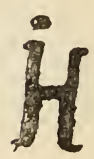

54

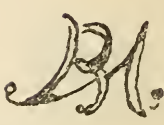

57

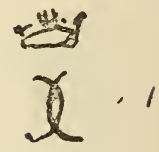

61

\section{9}

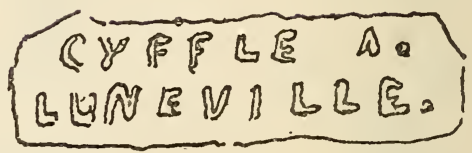

63

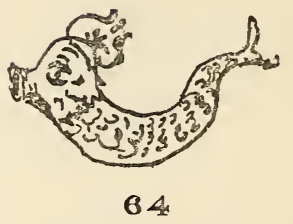

49.-Hard-Paste Porcelain of Strasburg (about 1724). Blue UnderGLAZE.

50.-Hard-Paste Porcelain of Strasburg (about 1745). Brown OnGLAZE.

51.-Hard-Paste Porcelain of Strasburg (about 1745). Rose-Colour ON-GLAZE.

52.-Hard-Paste Porcelain of Strasburg (about 1745). Blue UnderGLAZE.

53.-Hard-Paste Porcelain of Strasburg (1750 ?). Blue Under-glaze.

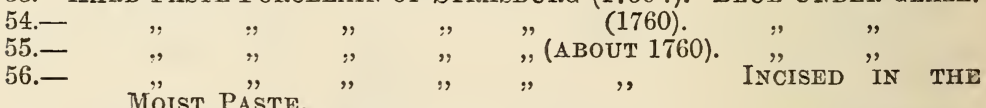
50.- MoIsT PÁste.

57-61.- Hard-Paste Porcelain of Niderviller. Blue Under-glaze. 62-63.-Terre De Lorraine. LuNéville. Incised in the Soft Paste. 64.-Hard-Paste Porcelain of Lille. Gold or Red On-Glaze. 


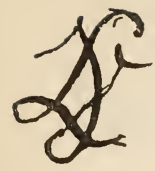

65

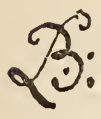

68

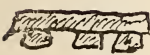

71

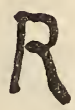

74

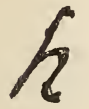

77

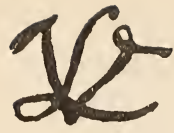

66

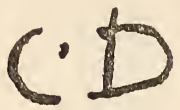

69

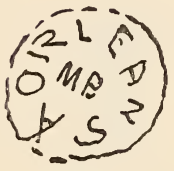

72

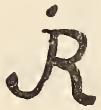

75

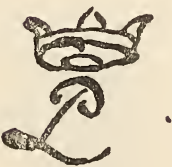

78

\section{Gaen}

67

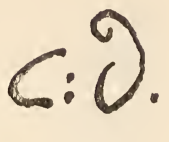

70

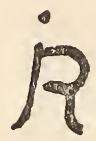

73

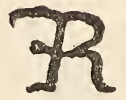

76

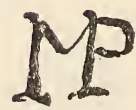

79

65-66.-Hard-Paste Porcelain of Valenciennes. Blue Under-Glaze.

67.CaEN. RED ON-GLaZe.

68.- $"$ " $", \quad "$, LAURAGUAIS. BLUE UNDER-GLAZE OR INCISED IN THE PASTE.

69-70.-Hard-Paste Porcelain of Limoges (Etghteenth Century). Blue UNDER-Glaze.

71.-Hard-Paste Porcelain of Orléans. Blue or Gold On-glaze.

72.- " " " , " RED ON-GLAZE.

73-75.- " " " " $"$ MaRseirles (ROBERT). BLUE UNDERGLAZE.

76.-Hard-Paste Porcelain of Marseilles (Robert ?). Red On-glaze. 77. - $" \quad " \quad$ Vincennes (ABout 1767). BLUE UNder78.-Hard-Paste Porcelain of Vincennes (about 1780?). Blue UNDER-GLAZE.

79.-Hard-Paste Porcelain of Etiolles. Blue Under-glaze. 


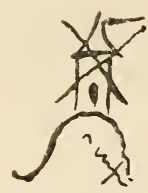

80

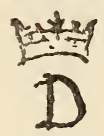

8.3

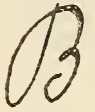

86

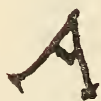

89

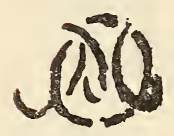

92

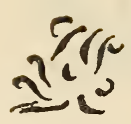

81

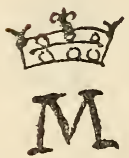

$3+$

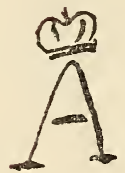

87

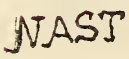

๑) 0

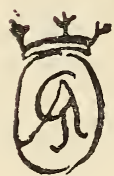

9.3

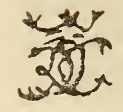

82

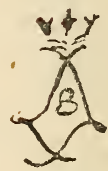

Si

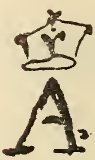

88

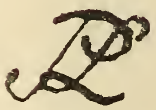

91

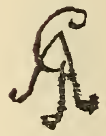

.94

80.- Hard-Paste Porcelain of Clignancourt (Paris). Blue UnderGLAZE.

81-83.-Hard-Paste Porcelain of Clignancourt (Paris). Red ONGLAZE.

84.-Hard-Paste Porcelain of Clignancourt (Paris). Red or Gold ON-GLAZE.

85.-Hard-Paste Porcelain of Clignancourt (Paris). Blue On-glaze. 86.- " " " BOISSETTE, BLUE UNDER-GLAZE.

87-88.- " " "old ON"Glaze". À LA ReINe, RUE THIrodx. RED OR 89.-Hard-Paste Porcelain of ̀̀ la Reine, rue thiroux. Blue UNDER-GLAZE.

90.-Hard-Paste Porcelain of Paris (rue Popincourt). Red On-glaze. 91-92.93-94.- " ON-GLAZE.

(RUe Pont-aux-ChOUX) ", ", (RUE DE BONDY). RED "OR GOLD 


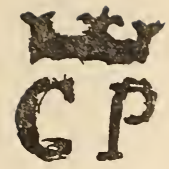

95

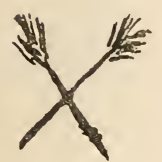

98

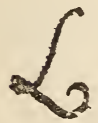

101

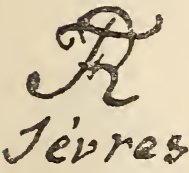

104

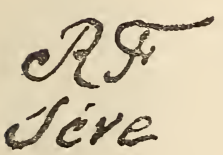

$10 \pi$

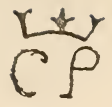

96

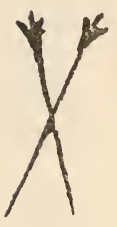

99

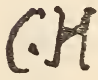

102

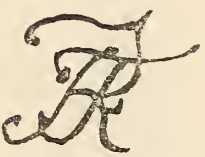

105

M. N $\mathbb{N}^{\mathrm{L}}=$ sèvres

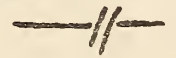

108

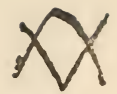

97

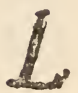

100

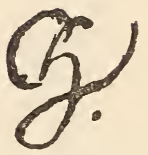

103

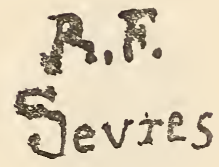

106

95.-Hard-Paste Porcelain of Paris (Comte d'artois). Red ON-glaze.

96.-

97.- " " " " "

98.- " " " " " Paris (RUE de la Roquette). Blde UNDER-GLAZE.

99.-Hard-Paste Porcelatn of Paris (rue de la Courtille). Blue UNDER-GLAZE.

100-101.-Hard-Paste Porgelatn of Paris (rue de Reullly). Blue UNDER-GLAZE.

102-103. - Hard-Paste Porcelain of Paris (rue de Reuilly). Red ONGLAZE.

104.-Hard or Soft-Paste Porcelain of SEvres. 1791. Blue Uxder-Glaze.

105. - " " " "

106.- " " " " " $\quad$ "

107.- " " " " " $" 1792.0, "$,

108.-Hard-"Paste Pörelati "OF SÈvres, 1804. Red ON-Ğlaze.

109.

., 1805-1810. 


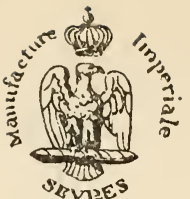

110

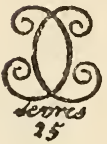

113

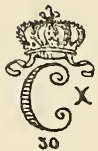

116

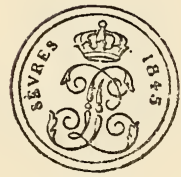

119

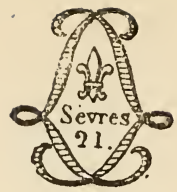

111

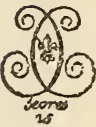

114

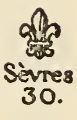

117

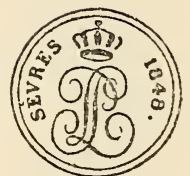

120

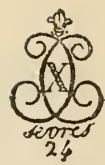

112

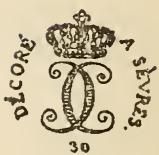

115

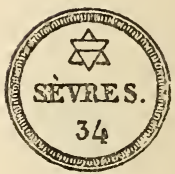

118

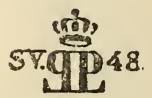

121

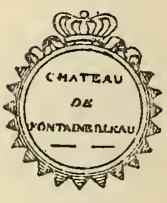

125

122

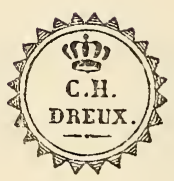

123

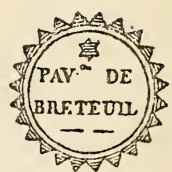

124

110.-Hard-Paste Porcelain of Sìvres. 1810-1814. Printed in Red ONGLAZE.

111.-Hard-Paste Porcelatn of Sìvres. 1814-1824. Blue Under-glaaze (the date mark consists of the two last figures of the year).

112.-Hard-Paste Porcelain of Sèvres. 1824 (Charles X.). Blue UNDER-GLAZE.

113-114.-Hard-Paste Porcelain of Sìvres. 1825-1828. Blue Under-glaze. 115.- " " " " $"$ 1829-1830. MARK IN BLUE FOR "Decorate”d Pieces.

116.-Hard-Pas'te Porcelain of Sèvres. 1829-1830. Mark in Blue for Pieces With Gold Bands.

117.-Hard-Paste Porcelain of Sèvres. 1830 (Louis-Philippe). Mark IN BLUE.

118. - Hard-Paste Porcelain of Sèvres. 1831-1834. In Gold or Blue. 119-120.- " " " " 1834-1848. 'THE KING'S CYPHER 121. - Hard-Paste Porcelain of Sìvres. 1845-1848. Mark PRinted iN CHROME-GREEN UNDER-GLAZE (indicating year of manufacture).

122-125.-HaRd-Paste Porcelain of Sìvres. (Marks added to those precedent when the pieces were intended for use in the royal châteaux). 


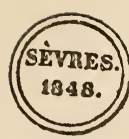

126

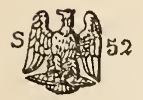

129

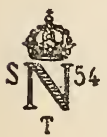

132

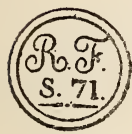

135

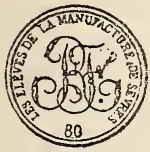

138

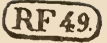

127

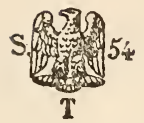

130

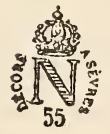

133

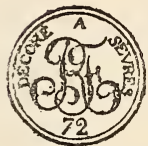

136

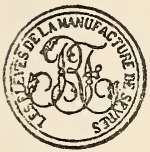

139

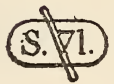

142

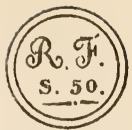

128

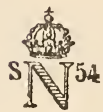

131

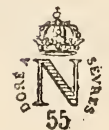

134

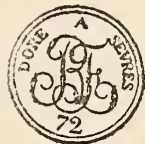

137

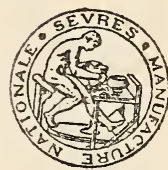

140

\section{SEVRES}

143

126-128. - Hard-Paste Porcelain of Sìvres. The Second Republic (18481. 1852). Mark printed in Red, to indicate the year of decoration. 129.-Hard-Paste Porcelain of Sèvres. 1852-1854. Red ON-Glaze.

130.-SOFT-PASTE

131. - HARD-PASTE

132.-DOFT-PASTE

",

-SOFT-PASTE "Th

133. -Mark, "Decorated" at SÈvres."

134.-MARK, "GILDED AT SÈvRES."

135.-SÈVRES PORCELAIN.

136-137.-SÈvres Porcelain.

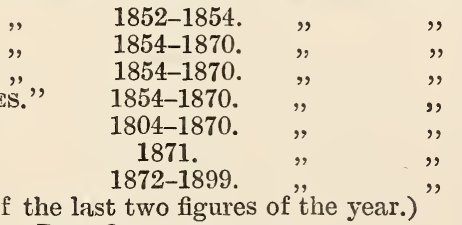

(The date mark consists of the last two figures of "the year.)

138.-SÈvres PoRCELAin. 1880-1889. Red ON-GLAZE.

139.- " " 1890-1904. Without DATE-MARK.

140.- " " " 1888-1891. MARK IN RELIEF.

141.-MARK in CHROME-GREEN UNDER-GLAZE printed on all pieces before firing (1848--1879).

142.-The same MARK cancelled by a cut of the wheel for defective pieces sold.

143.-MARK impressed in the MoIsT PASTe for the SÈvres "BISCUITS" (18601899). 


\section{MARES AND MONOGRAMS}

\section{OF THE PAINTERS, DECORATORS, AND GILDERS VINCENNES-SÈVRES}

$1750-1904$.

$\mathcal{C}$ Alonele, Birds, Animals, Emblems, 1758-1781.

J.A. André, Jules, Landscapes, 1843-1869.

(10. Anteaume, Landscapes, Animals, 1754 .

A. Apoil, Alexis, Figures, $1845-$ 1864.

$E A_{1}$ Apoil (Mme.), Figures, 186t1894.

A Archelais, Ornament, 18651902.

26 Armand, Birds, Flowers, etc., $1745-1746$.

A uu A Asselin, Portraits, Miniatures, 1750-1794.

os Aubert (the elder), Flowers, entered $175 t$.

A Auvillain, Ground layer, 1877-1904.

P.A Avisse, Ornament, 1850-1884. By: Bailly (junr.), Flowers, 1750-

B Ballanger, Decorator, 19021904.

.3 Barbin, Ornament, 1824-1839.

- Bardet, Flowers, 1751-1800.

Barrat, Garlands and Bouquets, $1780-1791$.
O3 Barré, Detached Bouquets, 1780-1791.

A3 Barré, Flowers, 1846-1881.

3 Barriat, Figures, 1852-1883.

(39) Baudoin, Ornament, Borders, etc., entered 1750 .

$\square$ Beequet, Flowers, etc., entered 1748 .

B Belet, Emile, Flowers, etc., 1878-1900.

B Belet, Louis, Decorator, 1879 1904.

B.r. Béranger, Figures, 18071846.

G. Bertrand, Detached Bouquets, $1750-1800$.

\& Bienfait, Gilding, entered 1756.

B Bieuville, Decorator, 18771904 .

I. Binet, Detached Bouquets, 1750-1800.

SC Binet (Mme.) née Chanou, Flowers, 1750-1800.

B Blanchard, Decorator, 1811.

A. B Blanchard, Alez., Ornament, 1878-1900.

NB Bocquet, Decorator, $1902-$ 1904. 
83.ઉ Boitel, Gilding, 1797-1822.

\$s Bonnuit, Decorator, 1858 1894.

Boucher, Flowers and Garlands, entered 1754.

Bouchet, Landscapes, Figures, and Ornaments, 1757-1793.

$\mathcal{L} \mathcal{3}$. Boucot, Flowers and Arabesques, 1785-1791.

Y. Bouillat, Flowers and Landscapes, 1800-1811.

A Boullemier, A., Gilding, 18221841.

హf.83 Boullemier(senr.), Gilding, 1822-1841.

83 Boullemier(junr.), Gilding, 1802-1812.

(3) Boulanger, Detached Bouquets, $1754-1800$

(5) Boulanger (junr.), Pastoral Subjects and Children, 1770-1781.

Or Brachard, Sculptor.

\$y Brécy, Ornament, 1880-1904.

$B_{n}$ Bulidon, Detached Bouquets, 1745-1792.

MB Bunel (Mme.), née Buteux, Flowers, 1778-1817.

I. Buteux (father), Flowers and Emblems, 17561786.

9. Buteux (elder son), Detached Borquets, 1773-1822.

¿ Buteux (younger son), Pastoral Subjects and Children, 1780-1794.

$B x$ Buteux, E., Flowers, after 1800.

IC. Cabau, Flowers, 1848-1884.

$\triangle$ Capelle, Friezes and Borders, entered 1745 .

C.I Capronnier, Gilding, after 1800.
Q Cardin, Detached Bouquets, entered 1749 .

5. Carrier, Flowers, etc., entered 1752.

C. Castel, Landscapes, Birds, Hunting Scenes, 1750 1800.

G.C Catteau, Decorator, 19021904.

* Caton, Pastoral Subjects, Children, P ortraits, entered 1753.

$S$ Catrice, Flowers and De. tached Bouquets, before 1800.

I.G Célos, Ornament (Pâte-sur. Pâte), 1865-1894.

$c h$. Chabry, Miniatures and Pastoral $\mathrm{Subjects}$, entered 1749.

72. Chanou (Mme.), née $\mathrm{Du}$ rosey, Flowers, before 1800.

c.p Chapuis (senr.), Flowers and Birds, before 1800 .

jc. Chapuis (junr.), Detached Bouquets, before 1800.

LC Charpentier, Decorator, after 1800 .

F C Charpin (Mlle.), Figures, Subjects, Portraits, after 1800.

* Chauvaux (senr.), Gilding, entered 1752 .

in chauvaux (junr.), Gilding, and Detached Bouquets, 1770-1783.

$\$$ Chevallier, Flowers, Bouquets. 1755 .

fi Choisy (de), Flowers and Arabesques, 1800-1817.

Chulot, Emblems, Flowers, Arabesques, e n t e r ed 1755 .

C.37\%. Commelin, Detached Bouquets, Garlands, before 1800.

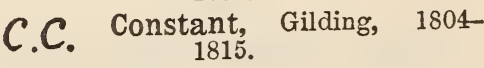


C.ซ. Constantin, Figures, 18231845.

f Cornaille, Flowers, Detached Bouquets, 1755-1793.

CC. Courey (de), Figure painter, 1866-1886.

C Coursajet, Decorator. Died 1886.

ع. Couturier, Gilding, entered 1783.

A Dammouse, Figures and Ornaments, 1862-1880.

A David, Decorator, 1852-1882.

D.JF Davignon, Landscapes, 1814.

D. F. Delafosse, Figures, 18051815.

Der Derichsweiler, Gérard, Decorator, 1858-1884.

D.8. Desperais, Ornaments, 17941822.

$D \hbar$ Deutsch, Ornament, 18151817.

CD Develly, Landscape, Genre, 1813-1848.

II Devieq, Ornament, 1880-1904.

D.I. Didier, Ornament, 1819-1845.

巡 Dieu, Chinese Subjects and Gilding, before 1800 .

五 Doat, Sculptor, Decorator (Pâte-sur-Pâte), 18781904.

K Dodin, Figures, Subject, Portraits, 1754-1803.

D) Drand, Chinese Figures, Gilding, before 1800 .

IS Drouet, Decorator, 1879-1904.

D.T Drouet, Flowers, 1828.

* Dubois, Flowers, Garlands etc., entered 1756.

A6.D. Ducluzeau (Mme.), Figures, Subjects, Portraits, 18181848.

5 yy Durosey, Gilding, 1802-1827.
D. Dusolle, Detached Bouquets, before 1800 .

D T Dutanda, Detached Bouquets, Garlands, before 1800.

(1) Eaubonne (d'), Decorator, 1904.

TE Escallier, (Nme.), Decorator, 1874-1888.

\& Evans, Birds, Butterflies, Landscapes, entered 1752.

F Falot, Arabesques, Birds, Butterflies, before 1800 .

HF Faraguet (Mme.), Figures, Subjects, 1856-1870.

䨤 Fiequenet, Flowers and Ornament, 1864-1881.

Fontaine, Emblems, Miniatures, etc., entered 1752.

F Fontaine, Flowers, 18271857.

( Fontelliau, Gilding, entered 1753.

Fouré, Flowers, Bouquets etc., before 1800 .

f Fournerie, Decorator, 1903.

A.F Fournier, Decorator, 18781904.

Qh? Fragonard, Figures, Genre, etc., 1847-1869.

Fritsch, Figures, Children, 1763-1765.

E.F Froment, Figure painter.

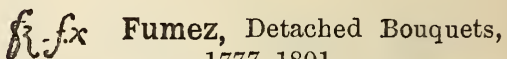
1777-1801.

G after 1800 .

Gauthier, Landscapes and Animals, 1787-1791.

⿷ Gébleux, Decorator, 18831904.

I.G Gély, Ornamentist (Pâte-surPâte), 1851-1888.

G Genest, Figures, Genre, 1752.

* Genin, Flowers, Garlands, Borders, etc., 1756. 
C. G. Georget, Figures, Portraits, y. etc., 1802-1823.

C d. Gérard, Pastoral Subjects, Miniatures, before 1800 .

Z. Gérard, (Mme.), née Vautrin, Flowers, before 1800 .

26 Girard, Arabesques, Chinese figures, etc., before 1800 .

Gob.R Gobert, Enameller, Figure painter, 1852-1891.

$I_{x}$ Gobled, Decorator, 1902-1904.

D. G. Godin, Gilding, 1808-1828.

落 Gomery, Flowers and Birds, 1756.

F. G Goupil, Figures, 1863-1879.

G $\mathcal{C}$ Grémont, Garlands, Bou-

C Grison, Gilding, 1749.

If Guillemain, Decorator, after 1800.

II Hallion,Eugene,Landscapes, 1884.

II Hallion, François, Gilder and Decorator, 1866-1895.

ith Henrion, Garlands, Detached Bouquets, before 1784 .

hc Héricourt, Garlands, Detached Bouquets, before 1800.

Jf Hilken, Figures, Pastoral Subjects, before 1800 .

I Houry, Flowers, etc., 17471755.

h.J Huard, Ornaments, 18111816.

¿わ. Humbert, Figures, 18621870 .

b. Huny, Flowers, Detached Bouquets, 1791-1799.

亡 Jardel, Decorator, 1886-1904. 2 Joyau, Detached Bouquets, f. Jubin, Gilding, before 1800 .

i. Julienne, Renaissance Ornament, after 1800 .

HL Lambert, Flowers, 18641896. S. Gá Langlacé, Landscapes, 1813-

GounR La Roche, Flowers, Garlands, Emblems, before 1800.

H. Lasserre, Decorator, 18961904.

T. Latache, Gilding, after 1800.

L Le Bel (elder), Figures and Flowers, before 1800 .

LC. Le Bel (younger), Garlands, Bouquets, 1780-1793.

Lo. Le Bel, Landscapes, 18041844.

\%ँ: Léandre, Pastoral Subjects, Miniatures, left 1785.

L Lecat, Ground layer, 18721904.

SS I. Lecot, Chinese subjects etc., before 1800 .

Ledoux, Landscapes, Birds, 1758.

J. Legay, Ornamentist, 1866 1884.

A. Léger, Decorator, 1902-1904.

LC IG Le Guay, Gilding, 1748.

L.P Le Guay, Figures, Subjects, Portraits, 1778-1781.

Leguay, Miniatures, Chinese children, 1772-1817.

$2 \mathcal{G}$ Legrand, Gilding, after 1800.

EL. Leroy, Gilding, 1864-1888.

Luu L Levé (senr.), Flowers, Birds, Arabesques, 1754.

Levé Félix, Flowers, Chinese subjects, before 1800.

AL Ligué, Decorator, 1883-1904. 
GL Lucas, Decorator, Modeller, 1878-1904.

R.B Maqueret (Mime.), née Bouillat, Flowers, before 1880 .

Martinet, Flowers, 18611878.

A6 Massy, Flower Groups etc., 1779-1806.

ME Maugendre, Sculptor, 1881-

EdeM. Maussion (Mule. de), Figures, 1860-1870.

$\int$ Mérault (elder), Borders, 1754-1791.

9 Mérault (younger), Bouquets, Garlands, 17861789.

II Mérigot, Ornament, 18481884.

BMR Meyer, Alfred, Figures, 1863-1871.

X Micaud, Flowers, Bouquets, Panels, 1759.

MC Micaud, Gilding, 1792-1812.

MorM Michel, Detached Bouquets, before 1800 .

QA Milet Optat, Decorator, 1862-1877.

LLM Mimard, Decorator, 18841904.

M Moiron, Detached Bouquets, 1790-1791.

5. Mongenot, Flowers, Detached Bouquets, 1754 .

At $\mathcal{L}$ Moreau, Gilding, 1809-1815.

Mo Morin, Marine and Military Subjects, 1754.

NV Morin, Gilding, 1888-1904.

AM Moriot, Figures, 1830-1848.

A Mutel, Landscapes, 1754.

$\pi q$ Niquet, Detached Bouquets, left 1792.

$\simeq$ Noël, Flowers, Ornament, 1755.
5 Nouailhier, (Mme.) née Durosey, Flowers, before 1800 .

o.ch Ouint, Charles, Decorator, 1879-1882.

C Ouint, Édouard, Ground layer, 1888-1893.

Ouint, Emmanuel, Ground layer, 1877-1889.

P Paillet, Figures, 1882-1888.

Pajou, Sculptor, 1750 .

Io Parpette, Flowers, Detached Bouquets, 1755 .

6.S Parpette (Mlle.), Flowers, entered 1794.

$\mathcal{L} \mathcal{S}$ Parpette (Mlle. Louison), Flowers, 1789-1825.

IP Peluche, Decorator, 18801904.

P.T. Petit, Flowers, 1756.

$f$

Pfeiffer, Detached Bouquets, before 1800 .

P.H. Philippine, (elder), Pastoral Subjects, Children, 1780-1791.

S.f. Philippine, Flowers and Ornaments, 1787-1791.

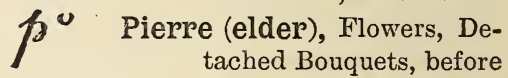
1800 .

'p.y

历

Pierre (younger), Bouquets, Garlands, before 1800 .

Pihan, Decorator, 1888-1904.

S. C. Pithou (elder), Portraits, Historical Subjects, before 1800 .

S. Pithou (younger), Figures, Flowers and Ornaments, before 1800 .

P Pline, Decorative Gilding, 1831.

IP Porchon, Gilder.

Pouillot, Detached Bouquets, before 1778 . 
A Poupart, Landscapes, 18151845.

HP. Prévost, Gilding, 1754.

Q Quennoy, Decorator, 1902.

: Raux, Detached Bouquets, before 1800 .

R Régnier, Ferdinand, Fig. ures, Subjects, 18201866.

JR Régnier, Hyacinthe, Figures, 1825-1870.

$\mathbb{R}$ Rejoux, Decorative Gilding, 1862-1890.

Renard, Émile, Decorator, after 1800 .

HfCR Renard, Henri, Decoration, Landscapes, 1881.

FVR Richard, Émile, Flowers, 1869-1900.

ER Richard, Eugène, Flowers,

86 Richard, François, Decorator, 1848-1878.

g/2. R. Richard, Joseph, Decorator, 1832.

I R Richard, Léon, Decorator, 1902-1904.

ศุ० Richard, Paul, Decorative Gilding, 1849-1881.

$\Omega_{x}$ Riocreux, Désiré, Flowers, 1807-1872.

$\dot{B}_{x}$. Riocreux, Isidore, Landscapes, 1824-1849.

GR Robert (Mme.), Flowers and Landscapes, after 1800.

$\mathcal{R}$ Robert, Jean-François, Landscapes, 1806-1812.

PR Robert, Pierre, Landscapes, 1806-1843.

X. Rocher, Figures, Miniatures, 1758.

Rosset, Landscapes, 1753.

Qf. Roussel, Detached Bouquets, before 1800 .

PMR Roussel, Figures, 1842-1872.
\$ Sandoz, Ornamentist, 1890 1904.

P.S. Schilt, Louis, Flowers, $1822-$ 1855.

S.h. Schradre, Birds, Landscapes,

ff. Sieffert, Figures, 1883-1888.

E. $-f$ Simard, Decorator, 18831904.

Sinsson, Flowers, Garlands, 1780-1795.

S..$\rho$ Sinsson, Flowers, 1820-1825.

$\because \because$ Sioux (elder), Detached Bouquets, G a r l and s , 1752-1792.

Sioux (younger), Flowers and Garlands, 17521792.

Fi Solon, M. L., Sculptor, Figures etc. (Pâte-sur-Pâte), 1862-1871.

S.7\%: Swebach, Landscape and Genre, 1806-1814.

$\checkmark$ Tabary, Birds, 1754 .

2 C Taillandier, Detached Bouquets, Garlands, 17531790.

- Tandart, Flower-Groups, Garlands, 1755.

Tardi, Detached Bouquets, 1757-1795.

Théodore, Gilding, before 1800.

d Thévenet (senr.), Flowers,

$j \mathcal{~} \mathcal{H}^{2}$ Thévenet (junr.), Ornaments, ${ }^{,}$Borders, 1752.

J.6. Trager, Jules, Flowers, Birds, 1841-1873.

H Trager, Henri, Decorator, 1887-1904.

I Trager, Louis, Decorator, 1888-1904. Or Tristan, Decorator, 1879- 
. Troyon, Ornamentist, 18021817.

FV Ulrich, Decorator, 1889-1904.

D Vaudé, Gilding, Flowers, 1753.

W Vavasseur, Arabesques, 1753.

Vieillard, Emblems, Ornaments, $1752-1790$.

Vignol, Decorator, 1883-1904.
2000 Vincent, Gilding, 1752-1791.

W Walter, Flowers, 1832-1882.

3) Weydinger, Gilding, about 1814.

X Xrowet, Arabesques, Flowers, 1750.

Yvernel, Landscapes, Birds, 1750 .

\title{
ARTISTS WHO SIGNED THEIR NAMES IN FULL.
}

\author{
$1740-1904$.
}

André, J., Landscapes, 1843-1869.

Baldisseroni, Figures, 1865-1879.

Barriat, Ornament and Subjects, 1852 . 1883.

Béranger, J, Figures, 1807-1846.

Bois, Th. du, Marine subjects, 1842 1848.

Boquet, Landscapes, 1804-1814.

Boquet (Mlle. Virginie), Landscapes, 1835-1863.

Bueq (Le), Landscapes, 1843.

Bulot, Flowers, 1862-1883.

Brunel, Figures, 1863-1883.

Cabau, C., Flowers, 1848-1884.

Célos, J., Ornament, 1865-1894.

Cool (Mme. de), Figures, 1870.

Courey (de), Figures, 1866-1884.

Degault, Figures, 1808-1817.

Demarne, Subjects, 1808-1814.

Demarne (Mile. Caroline), Landscapes, 1822-1825.

Denois (Mlle. Jenny), Portraits, 1820. Desbois, Sculptor, 1886-1887.

Develly, C., Landscapes, 1813-1848.
Didier, Ornament and Flowers, 18191845.

Dueluzeau (Mme. Adelaïde), Fortraits, 1809-1848.

Dufresne, Henry, Figures, 1862.

Fontaine, Ornament and Flowers, 1850.

Fragonard, Th., Subjects and Landscapes, 1847-1869.

Froment, Delormel, Eug., Figures, 1853-1884.

Gallois (Mme.), Figures, 1871.

Garneray, L., Marine Subjects, 18381842.

Gély, J., Figures, 1851-1888.

Ge orget, Figures, 1803-1806.

Goddé, Enamels and Reliefs, 1861-1863.

Hamon, Figures, 1849-1854.

Jacobber, Flowers and Fruit, 1818-1848.

Jadelot (Mme. S.), Subjects and Figures, 1864-1871.

Jaquotot (Mme. Victoire), Portraits, Subjects, 1801-1842.

Labbé, Flowers, 1847-1853.

Lamarre, Landscapes. 
Lambert, Landscapes, 1858.

Lasserre, Decorator, 1896-1904.

Laurent (Mme. Pauline), Figures and Subjects, 1850.

Langlacé, Landscapes, 1807-1844.

Langlois (Polyelès), Landscapes, $1847-1872$.

Lebel, Portraits and Landscapes, 18u41844.

Leguay, Subjects, Figures, 1778-1840.

Lessorre, Figures, 1834.

Lynybye, Landscapes, 1841-1842.

Mérigot, F., Flowers, Birds, 18481888.

Meyer-Heine, Figures, Ornament, 1862-1868.

Moriot, Figures, Portraits, 1830-1848.

Parent, L.-B., Figures, 1816.

Philip, Enamels, 1847-1877.

Philippine, Still-Life, 1785-1840.

Poupart, A., Landscapes, 1815-1845.
Régnier, Landscapes, 1836-1870.

Richard, E., Ornament, 1858.

Robert, Landscape, 1806-1843.

Rodin, Sculptor, Decorator, 1881-1883.

Roussel (P.-M.), Figures, 1848-1872.

Sehilt (Abel), Figures, Subjects, 18471880.

Sehilt (L.-P.), Flowers, 1822-1855.

Solon (MHe. L.), Higures, Subjects, 1862-1871.

Swebach, Subjects, Landscapes, 18061814.

Trager, J., Birds, Flowers, 1811-1873.

Treverret (de), Figures, 1819.

Tristan, Figures, 1863.

Turgan (Mme. Constance), Portraits, 1834.

Van Os, Flowers and Fruit, 1811-1814.

Van Marek, Subjects, Landscapes, 1825-1862.

Verdier, J., Designer about 1890. 


\section{Bibliography.}

Alluaud.-Statistique et Histoire de la Porcelaine du Limousin. Limoges, 1837.

Arclais de Montaimy.-Traité des couleurs pour la peinture en Émail et sur la Porcelaine. Paris, 1765.

Auscher, E. S.-Une manufacture nationale en, 1888. Paris, 1894.

Auscher, E. S.-Marie-Antoinette et la Manufe de Sèvres. Versailles, 1901.

Auscher, E. S.-La Manufacture de Sèvres sous la Rérolution. Versailles, 1902.

Auscher, E. S.-Les deux premiers Conservateurs du Musée de Sèvres. Versailles, 1903.

Auscher, E. S.-Les Céramiques cuisant à haute température. Paris, 1899.

Auscher, E. S.-La Céramique au Château de Versailles. Versailles, 1903.

Auscher ex Quillard.-Technologie de la Céramique. Paris, 1901.

Auscher et Quillard.-Les Industries Céramiques. Paris, 1901.

BAChelier, J. J.-Mémoire historique du l'origine et du progrès de la Manufacture de porcelaine de France. Paris, 1799.

Bachelier, J. J.-Réédité, avec préface et notes, par G. Gouellain. Paris, 1878.

Barth, C.-Porzellan-Marken ū Monogramme. 2nd edition. Stuttgart, 1865.

Bastenaire-Daudenart.-L'art de fabriquer la Porcelaine. Paris 1827.

Berthevin, N. P.-Cahier de formules chimiques concernant la fabrication de la Porcelaine. Manuscrit de 1777.

Bosc D'Axtic, P.-Ses œuvres ; contenant des mémoires sur la verrerie, la faïencerie, etc. 2 vols. Paris, 1780.

Boula de Mareuil.-Mémoire pour la Manufacture de porcelaine de France. Paris, 1776.

Brébisson, R. de.-La porcelaine tendre de Rouen. Evreux, 1895.

Breteuil, BARon DE.-Divers arrêts relatifs à la Manufacture royale de Sèvres. Paris, 1784.

Brongriart, A.-Notice sur la Manufacture royale de Sèvres. Paris, 1830. 
Brongniart, A.-T'Traité des Arts Céramiques, ou cles Poteries. 2 vols. et Atlas. Paris, 1844. 2nd edition, 1854.

Brongriart, A.-Traité des Arts Céramiques, avec notes et additions par Alphonse Salvétat. Paris, 1877.

Brongmiart et Riocreux.-Description méthodique du Musée Céramique de Sèvres. Paris, 1845.

Cavrois Louis.-Le refuge d' Etrun et la Manufacture d'Arras. Arras, 1877.

Chaffers, W.-Catalogue of the Special Exhibition of Loans at the South Kensington Museum. London, 1862.

Chaffers, W.-The Keramic Gallery. 2 vols. London, 1872.

Chaffers, W.-Marks and Monograms. 1st edition. London, 1860.

Chaffers, TV.-Marks and Monograms. 9th edition. Edited by F. Litchfield. London, 1900.

Champfleury (synonym for J. Hussow-Fleury).-Trésors d'Art du Musée de Sèvres. Paris, 1886.

Champfleury (synonym for J. Husson-Fleury).- - Histoire des faiences patriotiques sous la Revolution. Paris, 1876.

Collet, Ch.-Recherches sur les Manufactures de Valenciennes. Valenciennes, 1868.

Courajod, L.-Livre-Journal de Lazare Duvaux. Paris, 1873.

DARCEL, A.-Guide de l'amateur de faïences et porcelaines. Paris, 1864.

Darcet, J.-Deux mémoires sur l'action d'un feu égal. Paris, 17661771.

Darblay, Armé.-Mennecy-Villeroy. Paris, 1901.

Davillier, Baron J. C.-Histoire des Faïences et Porcelaines de Noustiers, Marseille, etc.-Paris, 1863.

Davillier, Baron J. C.-Les Porcelaines de Sèvres de $M^{\text {me }}$ du Barry. Paris, 1870.

Davillier, Baron J. C.-Une vente d'actrice sous Louis XVI. Paris, 1870.

Davillier, Baron J. C.-La vente du mobilier du Château de Versailles pendant la Terreur. Paris, 1877.

Davillier, Baron J. C.-Les origines de la Porcelaine en Europe. Paris and London, 1882.

Demmin, Auguste.-Guide de l'A mateur de Faïences et Porcelaines.

1st edition. Paris, 1861. 4th edition. 3 vols. Paris, 1873.

Demin, Auguste.-Histoire de la Céramique. Paris, 1868-75.

Demuix, Auguste.-Keramik-Studien. Vol. II. Das Porzellan. Leipzig, 1881-83.

Dillon, Edward-Porcelain. London, 1904.

Dubreuil.-La Porcelaine. Tome V. Fremy's Encyclopédie Chimique (Technical). Paris, 1885. 
Duc, J. L.-Rapports adressés au Ministre de l'Instruction Publique au sujet de la Manufacture de Sèvres. Paris, 1872-77.

Fourcroy.-Rapport sur un Mémoire du citoyen Brongniart. Paris, 1802.

Fraxks, Sir A. W.-Catalogue of Continental Porcelain. London, 1896.

Garban, E.-La Porcelaine. Paris, 1888.

Garnier, E.-Histoire de la Céramique. Paris, 1880.

Garnier, E.-La collection Gasnault au Musée de Limoges. Paris, 1881.

Garnier, E.-La Porcelaine tendre de Sèvres. Paris 1890.

Garnier, E.-The Soft Porcelain of Sèvres. London, 1892.

GARnier, E.-See also various articles in "Gazette des Beaux-Arts," "Bulletin de l'art dans l'industrie," etc.

Gasnault, P.-La collection Jacquemart au Musée de Limoges. Paris, 1876 and 1879.

Gasnault and Garnier.-French Pottery. London, 1884.

Gerspact, E.-La Faïence et la Porcelaine de Strasbourg. Strasburg, 1883.

Gerspach, E.-Biographie des Hannong. Paris, 1887.

Gerspach, E.-Documents sur les anciennes Faïenceries Françaises et la Manufacture de Sèvres. Paris, 1891.

Graesse, J. G. T.-Guide de l'amateur de Porcelaines et de Poteries Dresden, 1864. New edition, enlarged, edited by Jaennicke. Dresden, 1894.

Guettard.-Histoire de la découverte faite en France des Matières à Porcelaine.-Paris, 1765.

Hannong, J. A.-Reponse d'Hannong en refutation Dourlach, 1781.

Haudicquer de Blancourt, F.-The Art of Glass. . . Likewise the Making of China. Paris, 1697. London, 1699. New Edition, Paris, 1718.

Havard, H. et Vachon.-Les Manufactures Nationales. Paris, 1889.

HeLlot.-Portefeuille manuscrit contenant les procédés de la porcelaine tendre, 1753. (Library-Sèvres Museum.)

Heliot.-Manuscrit sur les procédés de la porcelaine de Sèvres et notes relatives à l'art et à l'histoire de la poterie, 1753-1760. (Library-Sèvres Museum.)

HeLLot.-Recueils des procédés de la Manufacture de Vincennes. (Library-Sèvies Museum.)

Hovdoy, J.-Recherches sur les Manuf ${ }^{e}$ lilloises de porcelaine et faïence. Lille, 1863.

Houdoy, J.-Histoire de la céramique lilloise. Paris, 1869.

Jacquemart, A.-Histoire de la Céramique. Paris, 1873.

JaCquemart, A.-History of the Ceramic Art (translated by Mrs. Bury Palliser). London, 1873. 
Jacquemart, A.-Les Merveilles de la Céramique. Paris, 1866-69. JACQUEMART ET LE BLANT.-Histoire artistique, industrielle et commerciale de la Porcelaine. Paris, 1862.

JAEnNicike, F.-Grundriss der Keramik. Stuttgart, 1878-79.

JAEnnicke, F.-Marken und Monogramme (taken from above). Stuttgart, 1878.

Joly, A.-Biographie de Cyffé. Paris, 1864.

LAmeire, Ch.-Rapport sur les Porcelaines modernes à l'Fxposition universelle de 1878. Paris, 1879.

Lauth, C._La Manufacture nationale de Sèvres, 1879-1887. Paris, 1889.

Lauth, C., et Dutallix, G.-Recherche sur la Porcelaine. Paris, 1888.

Le Breton, G._Le Musée Céramique de Rouen. Rouen, 1883.

LeJíal, A.-Recherches sur les Manufactures de porcelaine de l'arrondissement de Valenciennes. Valenciennes, 1868.

Lenolr. - Série de règlements et jugements sur Sèvres. Paris, 1779.

Litchfield, F.-Pottery and Porcelain. London, 1879 and 1900.

Macquer.-Procédés pour les pâtes des porcelaines du Roi à Sèvres. 1781. Manuscrit (Library-Sèvres Manufactory).

Marryat, J.-History of Pottery and Porcelain. London, 1850.

Marryat, J.-History of Pottery and Porcelain. 3rd edition, enlarged. London, 1868.

Marryat, J.-Histoire des poteries, faïences et porcelaines. 2 vols. Paris, 1866.

Maze-Sencier, A.-Les Fournisseurs de Napoléon $1^{\text {er }}$ et des deux Impératrices. Paris, 1893.

Milet, A.-Céramique Normande. Rouen, 1867.

Milet, A.-Historique de la faïence et de la porcelaine de Rouen. Rouen, 1898.

Milet, A.-Notice sur D. Riocreux. Paris, 1883.

Millot.-Origine de la Manufacture des porcelaines du Roi en 1740 . Manuscrit. (Library-Sèvres Manuf ${ }^{y}$ ).

Milly, CoMte DE._L'art de la Porcelaine. Paris, 1771.

Morey, M. P.-Les Statuettes dites de Terre de Lorraine. Nancy, 1871.

Papillon, G.-Guide du visiteur à la Manufacture de Sèvres. Paris, 1904.

Papillon, G.-Guide du Musée Céramique de Sèvres. Paris, 1904.

Petit-Lafitte.-Villaris et la découverte du Kaolin. Bordeaux, 1862.

Pheylpeaux.-Série de lettres patentes et arrêts. Paris, 1748-1764.

Pichon, Baron.-La Dubarry à Louveciennes. Paris, 1872.

Pottier, A.-La première porcelaine fabriquée en Europe, etc., inventée à Rouen. Rouen, 1847.

Ris-Paquot, O. E.-Dictionnaire des Marques et Monogrammes. Paris, 1873-1878. 5th edition. Paris, 1880. 
Ris.PAQUot, O. E.-Origine et privilèges de la Manufacture royale de Porcelaine de Vincennes et de Sèvres. Amiens, 1878.

Ris-Paquot, O.E.-Dictionnaire encyclopédique des Marques et Monogrammes. 2 vols. Paris, 1893.

Rrs-Paquot, O. E.-Faïences, Porcelaines et Biscuits. Paris, 1896.

Salvétat, A.-Leçons de Céramique. Paris, 1857.

Sartine, DE.-Ordonnances sur les Privilèges de Sèvres. Paris, 1763. SAUVAGE DrT Lemre.-Les statuettes en Terre de Lorraine.

SorL, E.-Recherches sur les anciennes porcelaines de Tournay. Paris, 1883

Solon, M. L.-History and Description of the Old French Faïence, London, 1903.

Stettexer.-Vincennes und Sèvres (Jahrbuch der Kœniglich Preussischen Kunstsammlungen.).

TAinturier, A.-Recherches sur les anciennes manufactures de porcelaine et de faïence d'Alsace et de Lorraine. Strasburg, 1868.

THoré, DE.-Les Anciennes fabriques de faïence et de porcelaine l'arrondissement de Sceaux. Paris, 1868.

Ujfalvy-Bourdon, C. E. DE.-Les Biscuits de Porcelaine. Faris, 1893.

UjFalvy-Bourdon, C. E. DE.-Petit dictionnaire des marques et monogrammes des Biscuits de Porcelaine. Paris, 1895.

IVallace Collectiox.-Catalogue of the Furniture, Porcelain, \&c. London, 1902. 2nd edition, 1904. 


\section{IN D EX.}

Adam Cliarles, 34, 42, 44, 82 Alluaud, 125, 166

Aloncle, 91

Angivillers, M. d', 77, 96, 97, 98, 131

Angoulême, Duc d', 97, 137; (factory of), 98, 13 7-138

Anstett, 118

Antheaume, 31

Antique, The (Influence of) $100,114,146,152,154$

Apoil, Mme, 162

Argenson, Marquis d', 48, $60,61,92$

Armand, 91

Arras, $86-87$

Artois, Comte d', 97, 130,

131; (factory of), 98, 122, $129,130-132,171$

Asselin, 91

Auberède, Marquis d', 134

Aubert, 91

Aubiez, Maurin des, 129

Augustus III. of Poland (Elector of Saxony), 39, 43, 61

A umont, Duc d', 92

Bachelier, 42, 44, 89

Bailly, 44

Barbin, F., 34, 35

Barbin, J. B., 35

Barrachin, 130

Barran, 143

Barrat, 91

Barrias, 164

Battelier, 143

Baumgart, 164

Bayeux, 168

Baynal de, 31

Bayonne, 79

Beaudoin, 91

Beaumé, 75

Beaupoil de St. Aulaire, 126 Bellevue, Château of, 49, 64

Benjamin, 131

Béranger, 153

Bergeret, 153

Berlin, 70

Bernis, Comte de, 68
Berthollet, 140, 144, 149 Bertin, M. de, $78,79,81,127$ Beyerlé, Baron de, 118, 119

Biarritz, 79

"Biscuit" figures, groups, $37,56,63,68,94,102,103$, 108-115, 117, 118, 119, 120, $124,125,131,132,136,138$ $147,148,158,164,167$

Boileau, 42, 62, 73, 74, 76, 77, $78,93,95$

Boilvin, 167

Boissette, 136

Boizot, 102, 109, 110, 139

Bolvey, 89

Boquet, 153

Bordeaux, 78; Archbishop of, 78,80

Bosio, 153

Böttger, J. F., 39

Boucher, A., 164

Bouchet, 91

Bouillat, 91

Boulanger, 104

Boullemier, 155

Bourdon-Desplanches, L. J., $130,131,132$

Bourg-la-Reine, 83-84, 171

Bracquemond, 167

Brancas-Lauraguais, Comte de, 75, 125; (Porcelain of), 124-125

Brichard, Eloi, 51, 52

Broillet, J. I., 128

Brongniart, A., 138, 146, 149-15 8, 160, 162

Brunel-Rocques, 161

Bulidon, 91

Bunel, 151

Burton, W., 25, 85

Busch, 73

Busts (Porcelain), 93, 94, 109, $110,131,132,136,138,139$ $147,148,158$

Buteux, 91, 105

Caen, 124, 166

Caffieri, 109, 110

Caillat, 41

Calonne, M. de, 86, 97, 98
Carrier-Belleuse, 163

Casting of porcelain, 85 134,160

Célos, 161

Chabry, 91

Chanon, 76

Chanou, J. B., 143

Chanou, 134, 135

Chantilly, $8, \mathbf{3 0 - 3} \mathbf{3}, 35,40$ $50,54,63,85$

Chapelle, J., 82

Chaplet, 168

Chapuis, 91, 104

Charpentier, F., 164

Chaudet, 153

Chauvaux, 91

Chavagnac, Comte de, 17, 56

Chenavard, 153

Chéret, 163, 164

Chicanneau, P., pèree, 19, 20 , $22,23,24,27,30$

Chicanneau, P., fils, 20, 23

Chicanneau, D., 24

Chicanneau, G., 20

Chicanneau, J. B., 20

Choiseul, M. de, 77

Choisy-le-Roi, 139

Chulot, 91

Cirou, C., 30, 31

Civita-Vecchia, 21

Clément, 139

Clignancourt (Paris), Fac. tory of, 135-136

Clocks, 105, 115

Clodion, 109, 110, 114, 153

Collections (see also Museums) : Chavagnac, 17, 56; Double, 104; English Royal, 64; Jones, 66, 95, 103; Rothschild, 64; Wal lace, 64, 65, 66, 67, 89, 90 103; Warmont, 86

Commelin, 91

Compiègne, 153

Constantin, 153, 158

Cornaille, 91

Cornflower decoration, 105, 121

Coudray, B., 20, 23

Courtille (Paris), Factory of, 133 
Custine, Comte de, 118, 119, 120

Cyfflé, 118-121

Dalou, 163

Dammousse, 167

Darblay, A., 35, 37

Darcet, 75, 125, 131, 144

Darnet, 78,80

Daru, 115

David, 153

Davillier, J. C., 2

Dax, 79,80

De Bey, 82

Decima, 6

Deek, Th., 164, 168

Delaplanche, 167

Deleneur, 87

Delft, 4, 14

Denon, V., 100, 155

Déparais, 153

Deruelle, P. 135, 136

Desbois, 163, 164

Desprès, 106

Dihl, 137, 138, 149

Dodin, 91

Dorez, B., 27, 28

Drand, 91

Drölling, M., 138, 153, 154

Dryander, 119

Dubarry, Madame, 65, 83, 93

Dubois (The Brothers), 33,

$40,41,47$

Dubois, 76,85

Dubois, P., 164

Dubois, V., 133

Ducheval, 124

Ducluzeau, Mme., 158

Dugareau, 126

Duhalde, 54

Duplessis, 42, 55, 89, 154

Duvaux, L. (quoted), 49, 92

Earthenware (English), 75, $76,84,87,118,124,134,140$ Ebelmen, 160, 163

England, 3, 4, 30, 138

Entrecolles, Père d', 75

Escalier, Mme, 161

Etiolles, 130

Evans, 91

Faĩence, 3, 4, 5, 6, 7, 11, 13, $15,19,63,71,72,73,117,118$, 121, 129

Falconet, 89, 109, 114, 115

Falot, 91

Fauquez, 87, 123

Firing of porcelain with coal, 122, 130

Flowers (porcelain), 43, 48, 49, 121, 127, 167
Folard, M. de, 77

Fontaine, 103

Fontainebleau, Palace of, 64, 153

Fourniera, 125

Fragonard, 153

Frankenthal, 70, 74, 76, 109, 116

Frémiet, 164

Fulvy, de, 40-45, 51

Furniture (inlaid), 92, 95, 156

Gaboria, 123

Gardet, 164

Gély, 161

Genest, 107

Gérin, 40

Gerréault, 84

Gien, 167

Girault-Demay, 168

Glot, R., 83

Gobert, 161

Gois, 110

Gombroon ware, 7, 22

Gomon and Croasmen, 139

Gravant, 40, 41, 54

Grellet, 125

Gros Caillou (Paris), Factory of, 128

Guerhard and Dihl, 137, 156

Guettard, 54, 75, 124, 125

Guiffrey, 19

Guy and Housel, 137

Hache \& Co., 167

Haguenau, 71, 72, 76, 116

Halot, 167

Hannong, B., 71

Hannong, C. F., 70-71

Hannong, Joseph, 76, 116, 117

Hannong, Paul, 71, 72, 73,

74, 93, 116

Hannong, Pierre, 76, 77, 116, $128,129,130,132$

Haudry, 143

Haviland, Ch., 166, 167

Haviland, Th., 167

Heim, 153

Hellot, J., 42, 44, 53, 54, 55,

$60,73,75,77$

Herbo, D., 87

Hettlinger, 96, 98, 100, 102 $105,106,141,143,144$

Höchst, 70, 72

Holland, 13, 14, 30

Huet, 123

Imari ware, 30

India companies, 6,28

Isabey, 153, 154
Jacobber, 153, 157

Jacques and Jullien, 35, 83 , 84

Jacquotot, Mme., 153, 158

Josse, 131

Jouenne, 44

Julien, 109, 110

Jullien and Bugnau, 128

“Kakiyemon" patterns, 30, 31

Kändler, 39

Kaolin, 8, 54, 55, 71, 75, 77, $78,80,81,116,117,118,124$, 127

Klagmann, 153, 158

Laborde, 81

Laferté, 136

Laffitte, 153

Lagrenée, 100, 144, 149

Lallement, 31

Lamarre, A., 128

Lamoniary, 123

Lancret, 37

Lanfrey, F., 118-121

Laporte, R., 167

La Roche, 91

La Rue, 56, 89, 109, 110, 114

La Seinie, 125, 126; Comte de, 126

I.assia, 134, 135

Laurent, 150

Lauth, Ch., 163, 164

Léance, 106

Le Bel, 91

Lebœuf, 104, 136̂, 137

Lecomte, 110

Lecot, 91

Leferre, 139

L.e Guay, 91, 138

Leguay, 91, 103, 153

Lemaire, 129, 138

Lemercier, 150

Lemire (Ch. Sauvage), 118 , $119,120,121$

Léonard, 164

Leperre-Durot, 122

Le Riche, 89, 106, 109, 111, 112

Levaux, 106

I.eveillé, 137

Lignereux, 144

Lille, 2 7-2 9, 32, 12 2-123

Limoges, 5, 80, 124, 125 166-167

Limprunn, 77

Lister, Dr. M. (quoted), 21

Locré, 133, 134

Loewenfinck, 72

Louis XIV., 4, 5, 7, 13, 19, 64

Louis XV., 11, 39, 42, 48, 49, $50,56,58,59,61,62,64,65$, $67,68,74,81,88,90,91,93$, 102

Louis XVI., 11, 88, 92, 93, 95, 
99. 102, 110, 111, 119, 131, 142

Louis - Stanislas - Xavier (Monsieur, afterwards Louis XVIII.), 127, 135, 156, 157; (factory of), 98, 135-136 Louis-Philippe, 129, 139, 157 Louveciennes, Palace of, 93 Lunéville, 118, 121

Luynes, Duc de (quoted), $42,43,44,47,48,59$

Machault, M. de, 56, 73

Macquer, 53, 75, 77-81, 131

Maine, Duchesse de, 82, 83

Malaguti, 150

Malmaison (1a), 153

Maria-Theresa of Austria, 94

Marie-Antoinette, 65, 67, 93, $94,96,97,104,105,112,119$, 137; (busts of), 94, 109; (factory patronised by), $98,104,13$ 6-137, 171

Marie-Josèphe (Dauphiness), $39,43,49$

Marks, 15, 26, 27, 28, 29, 33, $34,35,36,37,38,50,52,56$, $57,69,72,73,83,84,86,87$, $92,105,107,117,121,123$, $124,125,126,128,129,130$, $132,133,134,135,136,137$, $138,139,140,148,158,159$, $165,166,170,171,172$

Marly, Château of, 64

Marmontel, 103

Marre de Villiers, 139

Marseilles, 127, 128

Massié, 125

Masson, 148

Mathians, 106

Mathieu, 42

Mehun-sur-Yèvre, 167

Meissen (also under Porcelain), 48, 71, 150

Mennecy-Villeroy, 8, 32, 34 $38,50,63,83,84,85,87$, 171

Mérault, 91

Merchi, 112

Meudon, Château of, 19, 64

Meyer, 144

Micaud, 91

Millot, $40,58,77-80$

Moitte, 135

Monnier, 130

"Monsieur" (factory of), 98, 135-136

Montigny, M. de, 81

Moreau, 132

Moreau-Marie, 23

Morel, 133

Morin, G., 20, 22

Morin, 91, 103

Moriot, 153

Munich, 77
Museums (sce also Collections): British, 7; Cluny, 37; Colmar, 119; Condé (Chantilly), 33; Dresden, 6, 43; Limoges, 14, 35, 130 ; Louvre, the, 100; Mennecy, 37; Pitti Palace, 100; Rosenburg, 91; Rouen, 17; Sèvres, 13, 14, $18,25,34,40,47,48,49,66$ $68,78,99,100,102,106,109$ $111,117,120,122,125,123$, $130,136,137,138,139,140$, 151, 153, 158; Vatican, 154 Versailles, 99, 120, 156; Victoria and Albert, 2, 3 , $7,14,25,32,66,83,84,86$, $95,99,103,104,115,124$

Napoleon I., 146, 150, 152 , $153,154,155$

Napoleon III., 153

Nast, 138, 156

Naudot, 168

Niderviller, 118-121, 132

Niquet, 91

Noailles, Maréchal de, 74

Noël, 91

Nord, Comte du, 105

\section{Oberkirch, 117}

Oberzell, 117

Orléans, 13, 84-85, 126

Orléans, Duc d', 22, 23, 28, 30 ; (factory of, at Paris), 139

Osson, Marquis d', 130

Oudry, 99, 113

Outrequin de Montarcy, 139

Pajou, 93, 94, 104, 109, 110, 112, 114

Parent, 95, 96

Paris, 4, 8, 13, 14, 20, 23, 27, $28,34,82,97,119,12$ ?, $123-$ 140, 182

Parisian manufactories, 98, $104,122,126,128-140$, 172

Passau, 72, 74, 117

Passy, 14

Pâte-sur-Pâte, 161

Pélissier, P., 27

Penthièvre, Duc de, 83, 84

Percier, 153, 157

Perregaux, 145

Perrot, 13

Perrotin, 106

Peterinck, 85

Petuntse, 54, 55, 71, 77, 78, 151

Peyrusson, 16?

Pfeffel, 77
Philippine, 153

Pierre, 91

Pigalle, 109, 110

Pillivuyt \& Co., 167

Pithou, 91

Plaques (painted), 95, 99, 138, 158, 161

Pompadour, Marquise de, $48,58,61,62,68,83,88,90$ 93

"Pont-au-Choux" (factory of), 139

Porcelain: of Bow, 31, 48, 50, 75; of Chelsea, 31, 32, 48, 50, 75; Chinese, 1, 3, 6, $7,8,11,14,34,54,60,70$, 151, 160; Copenhagen, 164 ; Florentine, 1, 2; Hard. paste, $8,11,12,39, \mathbf{7 0 - 8 1}$, $84,88,96,100,106,108,116$ $132,146,147,150,151,164$; Japanese, 1, 6, 11, 30, 31, 34, 54, 60; Meissen, 30, 31, $32,34,39,40,42,54,60,64$, $70,82,109,119,113$; Softpaste, $2,8,9,11,12,40,61$, $75,84,88,108,126,146,147$, $150,151,160,164,168,169$; of Vienna, 94; of Worcester, 31, 32, 48, 87, 168

Poterat, L. (Sieur de St. Etienne), 15, 16, 20, 21, 30

Potter, 31, 139

Pouyat, 134

Pouyat and Alluaud, 166

Prévost, 91, 104

"Prince of Wales" factory, (Paris), 139-140

Propping of Porcelain, 9, 10, 47

Rambouillet, 105, 153

Réaumur, 23, 54, 75

Redoutté, 153

Regnault, V., 160, 162, 163

Regnier, 96, 141, 143

Régnier, 150, 153, 163

Réverend, C., 13, 14, 15, 16 , 19

Ringel, 167

Ringler, 72

Riocreux, D., 151, 161, 162

Rivet, 133

Robert, 161, 162, 163

Robert, J. G., 127

Rodin, 163

Roland, 143

Rosset, 91

Rouen, 4, 8, 14, 15, 16, 19, 20

Rouen Porcelain, 15-18, 27, 32, 72

Rousset, 154

"Rue de Bondy" (factory of, 137-138; " de Crussol" (factory of), 139-140; “Popincourt" (factory of), 138- 
139; " de la Roquette" (factory of), 133; "de Reuilly" (factory of), 134135; "Thiroux" (factory of), 104, 106, 136-137, 171 Russia, Empress of, 103, 104 Russian Service, 104

Sailly, N., 126

Saint-Amand, 87, 168, 171

St. Antoine (faubourg), 23 , 24, 133, 134, 139

Saint-Brice, 139

St. Clond, 8, 14, 16, 17, 18,

19-2 7, 28, 29, 30, 32, 35, 72 Saint-Denis, 136

St. Denis (faubourg), 130

St. Germain, Château of, 19, 64

St. Honoré (faubourg) 23, 24

St. Lazare (faubourg), 130

St. Yrieix, 78, 80, 116, 118, 125, 151

Salmon, 144

Salvétat, A., 150, 151, 162, $1 € 3$

Savy, H., 127

Saxony, Elector of (see also Augustus), 78

Sceaux, 36, 82-83

Schilt, 153

Schœlcher, 131

Sèvres, 8, 32, 36, 50, 5 8-69, $70,75,85,86,88-115,118$, $132,136,141-166,169,170$, 171; branch works of, 125; edicts in favour of, 62,63 , $83,96-98,129,131,142,152$; finances of, $60,61,62,64$, $90,142,143,144,145,146$,
150, 156, 157, 163; “ jew. Trou, 23, 24 elled" porcelain, 102, 103; new porcelain of, 164,165 ; painters and decorators, 91, 150 (see also Special marks); staff and wcrk. men, 107, 142, 149, 150

\section{Sinsson, 153}

Sioux, 91

Solon, M. L., 72, 83, 87, 161

Souroux, 133

Statuettes, Groups, etc., 7, $36,37,50,56,63,68,78,98$, $102,103,108-115,117,118$, $120,121,123,124,132,136$, 164,167

Steinauer, 150

Strasburg, 70-74, 76, 116117,119

Suchetet, 164

Sweden, King of, 103

Swebach, 153, 155

Tachard, 4

Taillandier, 91

Tainturier, 117

Talleyrand, 145, 148

Tandart, 91

Tardy, 91

Thomire, 153

Toulouse, E., 139

Tournay, 28, 85-86, 87, 123, $124,168,171$

Tours, 126

Trianon, The, 64, 94, 105, 153, 155

"Trois Levrettes" (factory of), 133
Tuileries, The, 153

Valenciennes, 123-124

Vannier, 123

Van Spaendonck, 149

Vauquelin, 151

Vaux, 132

Verdun, M. de, 58, 76

Vermonet, 136

Versailles, Palace of, 4, 19, 64, 90, 94, 105, 131, 153; exhibitions at, $90-91,101,105$; hospital of, 20

Vieillard, 91

Vienna, 70, 72, 94

Vierzon, 167

Villaris, $78,79,80$

Villeroy, Duc de, 34

Vincennes, 8, 31, 32, 34, 36, $\mathbf{3 9 - 5 7}, 65,72,73,74,82$ 169,170 ; Finances of, 43 , $44,45,46,51,53$; Flower. pieces, 43, 48, 49; Hardpaste porcelain, 128-130, 132, 138; Soft-paste processes, 46, 47, 85; Staff of, $42,44,52,53,74$

Vincent, 91

Wakenfeld, 71

Watteau, 37

Wedgwood's wares, 95, 106, 115

Xrowet, 65 





\section{z}

RARIES SMITHSONIAN INSTITUTION
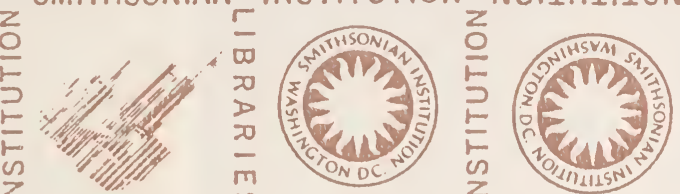

D
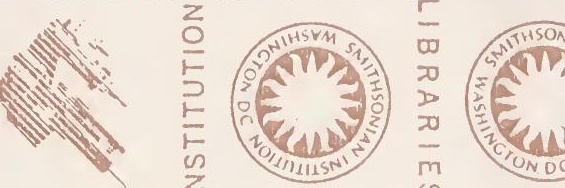

OIISN

in

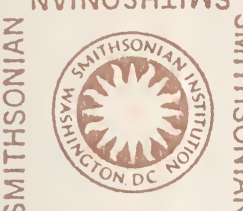

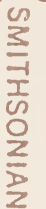
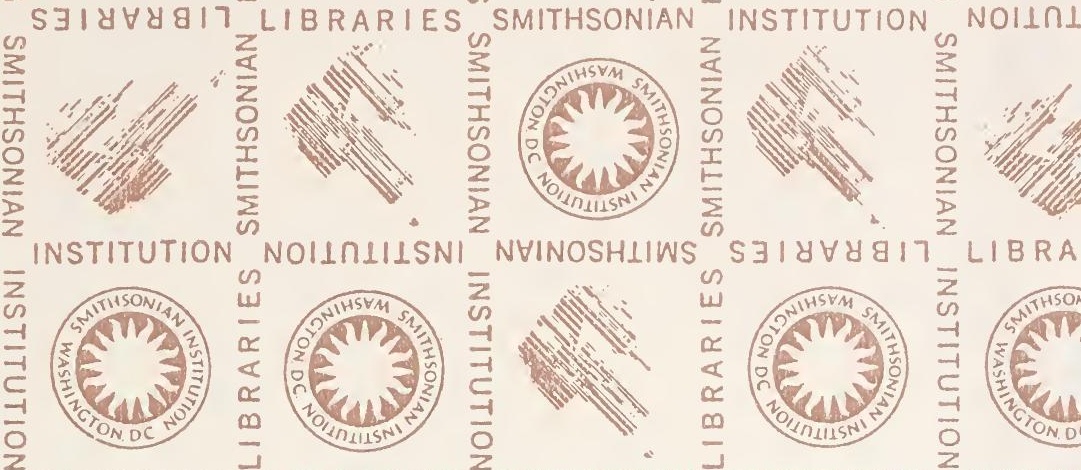

OIISNI ${ }^{-}$NHINOSHLIWS
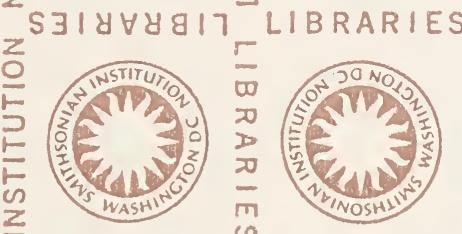

SMITHSONIAN
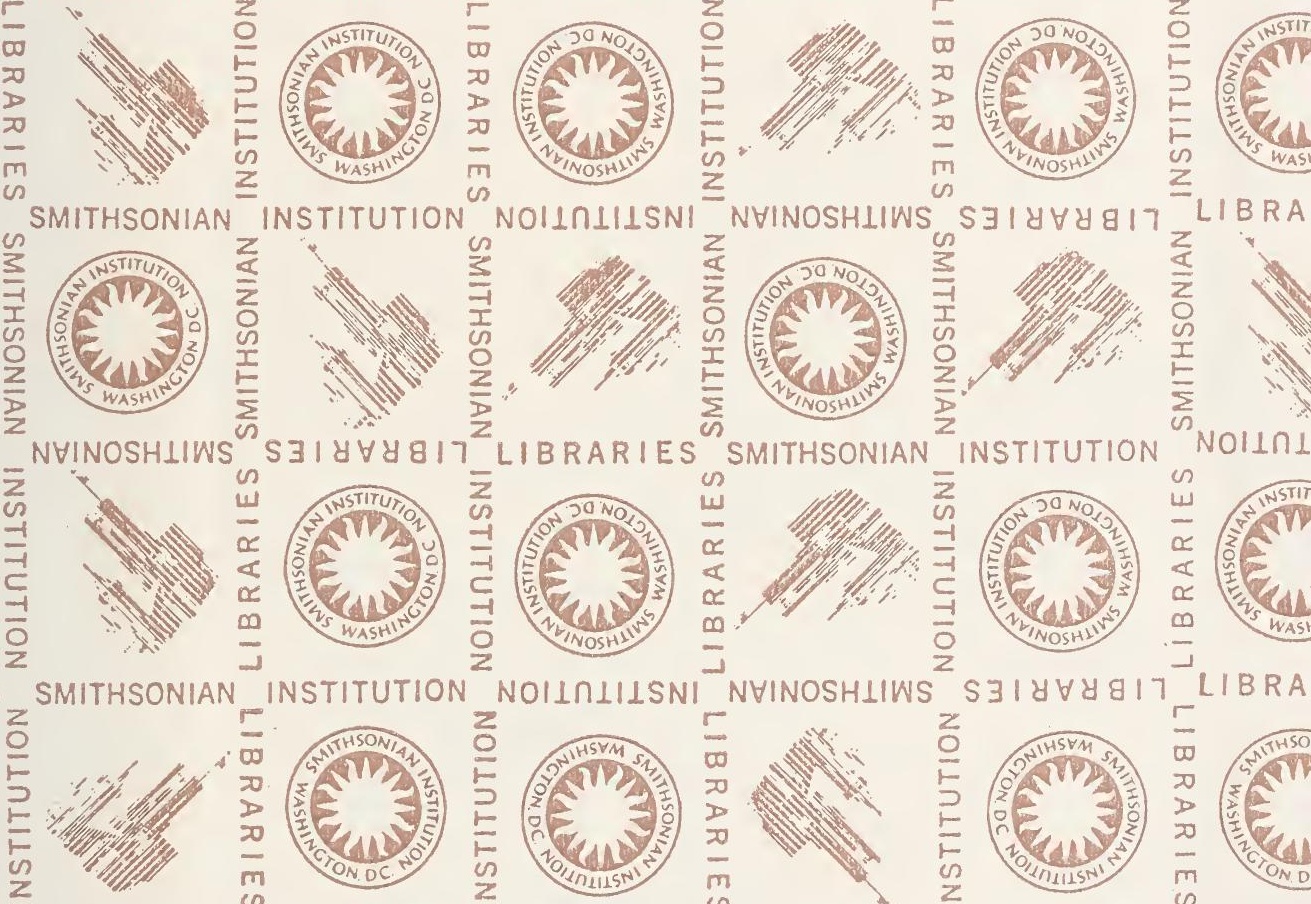

LIBRA
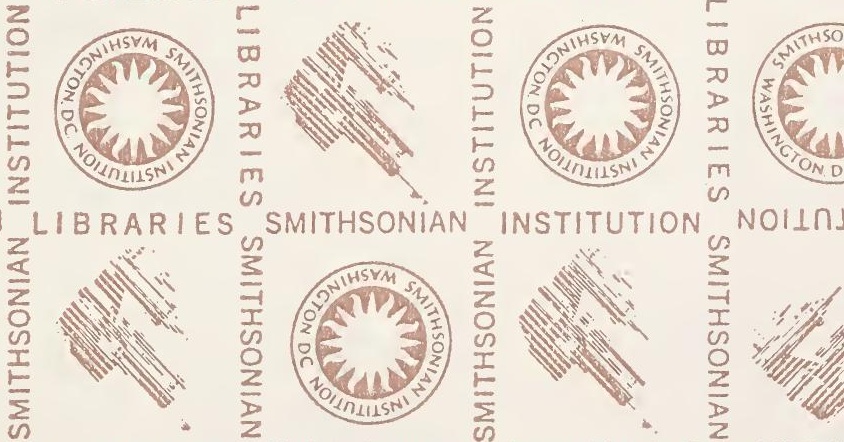

NOIIn!
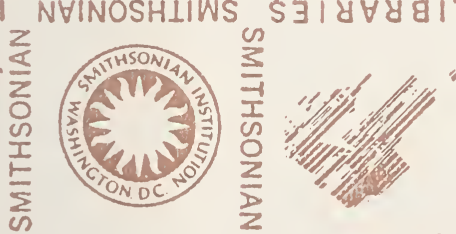

INSTITUTION
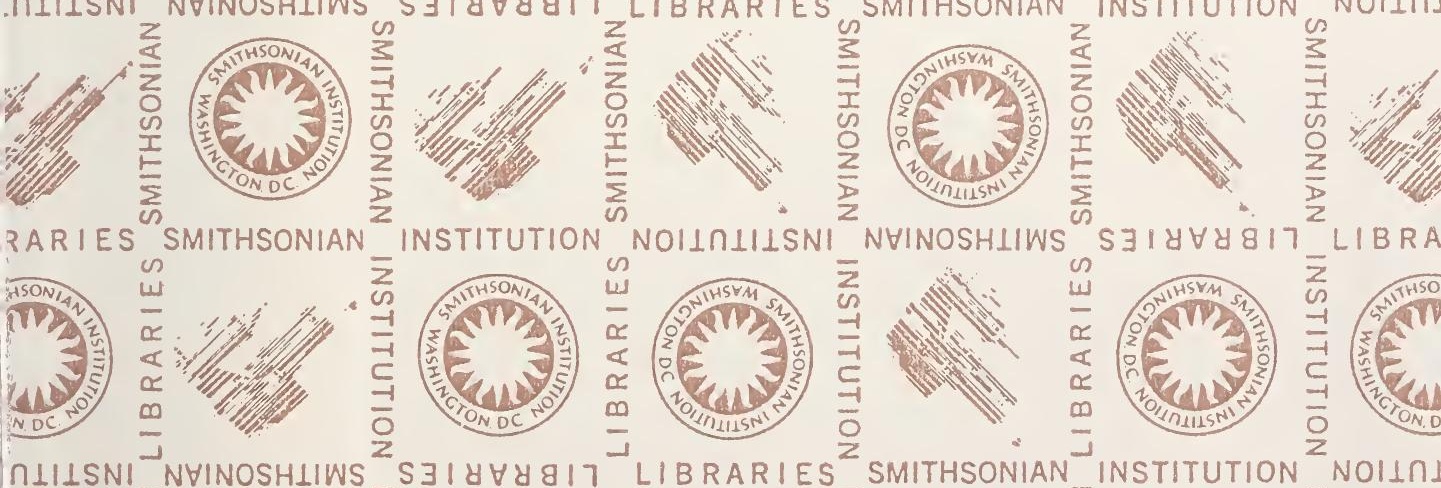

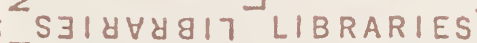

SMITHSONIAN INSTITUTION

NOIIn] 


$$
4
$$$$
\text { 器 }
$$

1) 